


\section{Brandeis University}

\section{Library}

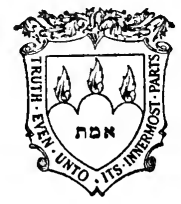

This volume is part of the George A. Barton Collection patiently gathered through a lifetime of devotion by one of the most distinguished scholars in the field of Biblical archaeology.

With the Compliments of the Author and of the Dropsie College 




\section{THE BOOK OF ESTHER}

\section{IN THE LIGHT OF HISTORY}

JACOB hOSChander, Рh.D. (Marburg)

INSTRUCTOR IN COGNATE LANGUAGES IN TIIE DROPSIE COIIEGE

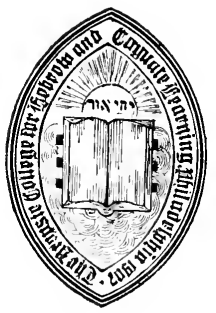

P H I L A D ELPHI $\Lambda$

THE DROPSIE COLIEGE

FOR IIEBREW $A$ N I COGNATE LEARNING 1923 
$F=\therefore \cdots$

$H-2$

PRINTEH IN ENGLANA AT THE OEFORH UNIVERSITY PRFS IX FREDERICK HALL 
TO MY WIFE

\section{BERTHA HOSCHANDER}

IN AFFECTIONATE APPRECIATION

OF IIER ENCOURAGEMENT AND DEEP INTEREST IN

$$
\text { MY STUDIES }
$$

THIS BOOK IS DEDICATED 



\section{PREFACE}

THE aim of the present book is to interpret the Book of Esther from the historical point of view and to show the historical origin of the Festival of Purim. It is this historical aspect which fundamentally differentiates the present interpretation from all previous attempts at explaining the origin of the Purim Festival on which the Biblical narrative is based, as in none of them has there been suggested an historical reason, drawn from non-Biblical sources, for the danger impending over the Jews during the Persian period. The very fact, however, that outside of the Biblical narrative which attributes this danger to the enmity of a Persian grand vizier toward a single Jewish individual, nothing was known from external historical sources to account for such an event, was reason enough for doubting or denying altogether its historical character. My interpretation, however, is based upon an historical event during the Persian period, well known from nonBiblical sources, the consequences of which must have been disastrous to the Jews of the Persian empire. This event I considered of so great importance for the Jews of the Persian empire that, in investigating the subject, I felt constrained to declare, that if the Book of Esther had never been written, historians might have found out, that during that period the Persian Jews were threatened with complete extermination. The real problem is not, whether such an event did happen, but how the Jews escaped the danger, and its solution is presented, 1 claim, in the Book of Esther. The historical event, on which the Biblical narrative is based, is treated in the sixth chapter. 
In placing this novel interpretation of the Book of Esther for the consideration of Biblical and Semitic scholars, I am far from deluding myself into the belief that it will immediately find ready acceptance. $A s$ far as the modern critics are concemed, the non-historical character of the Book of Esther is at present with them the standard opinion, and my interpretation would come into collision with what may be properly termed a dogmatic bias. Conservative scholars, on the other hand. might look askance at an interpretation of a Biblical narrative, which on numerous points deviates from the traditional vicws. However, the only aim of scholarship, be it modern or conservative, is truth, and if my solution of this Biblical problem has attained that goal, I may rest assured that it will finally prevail, notwithstanding the current opinions.

In conclusion I wish to acknowledge my special indebtedness to the President of the Dropsie College, Doctor Cyrus Adler. who during the initial stages of this investigation and liter during its preparation for publication assisted me with helpful criticism, both in the preparation of the manuscript and in the reading of the proof.

JACOB HOSCHANDER.

Drorsie College,

Pinlladelihia. PA.,

Deccmbcr, 1922. 


\section{TABLE OF CONTENTS}

\section{CHAPTER I}

THE ill-fate of the Book of Esther-The Greek version-The apocryphal additions - Talmudic interpretations-Luther's verdict-Modern theoricsConservative exegetes-Errors of the interpreters-The interpolators in the Maccabean period-The erroneons identification of the king of Esther

\section{CHAPTER II}

The improbability of Mordecai's genealogy - His access to the harem-Haman's genealogy-The etymology of his proper and gentilic names

\section{CHAPTER III}

The author of Esther as an historian-The date of these events-The extent of the Persian empire-The coronation festivities-Xerxes' war with Greece-His queen $\Lambda$ mestris-The Jews outside of the Persian empireThe diaspora-Jewish persecutions in post-exilic times-The improbability of Haman's decree-Xerxes' character-His attitude towards the JewsThe new possessions of Ahasuerus . . . . pp. 30-4 I

\section{CHAPTER IV}

$\Lambda$ hasucrus' identity with $\Lambda$ rtaxcrxes II Mnemon-Plutarch's Life of $\Lambda$ rtaxerxes-Plutarch's sources and their reliability $-\Lambda$ rtaxerxes' characterHis relations to the Greeks-The Peace of $\Lambda$ ntalcidas-The rebellion of Cyrus the Younger-The date of the battle of Cunaxa- $-\Lambda$ rtaxerxes' celebration of his victory-His domestic life-Quarrels between his queen and his mother-The rule of the harem-The queen's disobedicnce-Her degradation and murder-Her name $-\Lambda$ rtaxerxes' concubines $-\Lambda$ rtaxerxes' suspicions against his grandees-His palace at Susa-The name Ahasucrus in the Hebrew version $-\Lambda$ comparison between Xerxes and $\Lambda$ rtaxerxes IIThe resurrection of the Persian empire-The Arsacides alleged descendants of $\Lambda$ rtaxcrxes 11 His proper nane-The uniformity of the Seriptures-The name $\Lambda$ rtaxerxes in the Greek version . . . . . pp. $+2-80$ 


\section{CHAPTER V}

The term 'Judeans'-The renascence of Isracl's religion-National aspirations-The religious propaganda among the exiles-Religious creeds and the conduct of their adherents-The hatred of the Babylonian Jews toward Babylonia-The attitude of the Judeans in Egypt towards this country-The conduct of the wealthy Jews in Babylonia-The cause of persecutions-The Judeans' attitude towards the Persians-Zoroaster's 'monotheistic' religion-The characters of Mordecai and Esther-The two opposing tendencies within Judaism-Mordecai versus Ezra and NehemiahThe effect of the religious persecutions-The predicament of the Sopherim-The omission of all religious elements in the Book of Esther--The attitude of the Rabbis towards this book-The omission of the names of Mordecai and Esther in Sirach's Fathers of the World . . . pp. 8I-II7

\section{CHAPTER VI}

The nature of the danger recorded in the Book of Esther-The introduction of anthropomorphic images into the Zoroastrian religion-The reform against Zoroastrianism-Religion and state-Zoroastrianisin as the supreme religion of the Persian empire-Anahita as the representative and manifestation of Ahuramazda-The effect of the reform- $\Lambda$ Persian tradition-The reform affected the Jews-The religious persecntions-The strictly religious Jews-The festivals of Anahita-Historical reminiscences of the persecutions

. pp. $118-13^{8}$

\section{CHAPTER VII}

The author of the reform-The success of the reform among the Persians-The resistance of the Jews-The contrary effect of the persecutions upon them-Their plea-Esther's relationship to Mordecai-His identity among Gentiles-The necessity of his having some position at the courtI I is discovery of a conspiracy-His attitude towards the persecuted JewsHis rufusal to bow down to the prime minister-His confession of being a Jew-The prime minister's hesitation to punish him-His action and the creed of the Jews-The significance of the casting of lots-The simultancity of Purim with a non-Jewish festival-The efagonena-Haman's difficult task-The Jews in Palestine-Itaman's accusation-His aim-The sanguinary style of his decree-His promise of ten thousand talents-His wealth - The king's investigations - The carly promulgation of the decreeIts being reconsiclered under the influence of wine . . pp. 139-182 


\section{CH.PTER VIII}

The effect of the decrec upon Mordecai-His sources of informationThe numerous Jewish cunuchs-Esther's attitude towards the calamity of the Jews-Mordecai's messagc-Esther's arguments-Mordecai's threatsEsther's compliance-Her omission to request an audience of the kingHer difficult task-Her diplomacy-Her invitation of Haman-The advice of Haman's friends-The gallows-The incident of the honoring of MordecaiThe king's inquiry-His suspicions of the prime minister's disloyaltyThe king's apparel-A lesson in modesty-The king being ignorant of Iordecai's creed-Haman's reflections-The deliberation under the influence of wine-Esther's accusation of Haman-The king's indecision-Haman's plea with Esther-The king's ridiculous accusation of Haman-The covering of Haman's face-His denunciation by Harbonah-A parallel between Tissaphernes' and Haman's fate-The partiality of the Jewish point of view

\section{CHAPTER IX}

The infallibility of kings-The forfeiture of Haman's property-The downfall of his whole family-The king being acquainted with the close relationship of Mordecai to Esther-His reflections upon Mordecai's modesty and Haman's ambition-The attitude of the people of Susa-The law concerning the worship of Anahita not being enforced-Its resurrection under Artaxerxes 111 Ochus-Haman's decree being still in force-Esther's plea-The king's point of view - The sanguinary style of Mordccai's decree-The interpolaters-The decree in the Greek version-lts remarkable addition-Mordecai in the pomp of a prime minister-The joy of the people of Susa - The conversion of many Gentiles-The joy of the Jews at being given permission to defend themselves-The hope of their enemies to execute Haman's decree-The fight at Susa-The Jews being attacked on the second day-Haman's special decree for Susa-The exposing of the bodies of Haman's sons-The number of the slain Gentiles-'The Festival of Purim-The attitude of the Sopherim towards it-Its secular character and Persian features-Mordecai's Letter of Purim-The 'Fast of Esther'Mordecai's second Letter of Purim-The opposition of the SopherimPurim a safeguard against Persian persecutions-The composition of the Book of Esther in a later period-The Persian annals-Mordecai's Persian name-His characterization by the author of the Book of Esther pp. 230-299 



\section{THE BOOK OF ESTHER IN THE LIGHT OF HISTORY}

\section{CHAPTER I}

The ill-fate of the Book of Esther-The Greek version-The apocryphal additions-Talmudic interpretations-Luther's verdict-Modern theoriesConservative exegetes-Errors of the interpreters-The interpolators in the IIaccabaean period-The erroneous identification of the king of Esther.

IF there were any truth in the cabbalistic maxim, 'All depends on fate, even the Scriptures', we would say that the Book of Esther was ill-fated from the very outset. It relates how once upon a time, in the Persian period, a terrible danger to the Jews was averted by natural circumstances, without any visible divine intervention. In our sceptical age, we should expect such a story to be held the most credible of all the narratives of the Old Testament. Just the contrary has happened. None among them is more discredited by modern exegetes, except a few, than this story. The narrative is by some partly doubted, partly denied, by others denied altogether. But it is only fair to say that they are not to blame. ${ }^{1}$ The current interpreta-

1 There is, however, no excuse for the unfair treatment of the story of Esther by not a few of the modern eritics who are not satisfied, with demonstrating its unhistorical claracter, but for the purpose of impressing upon the mind of the reader its fabulous absurdity, frequently distort the facts and make forced interpretations. The arguments and theories of many of them would be more convincing if they were presented in an objective manner, and were nct seasoned with abusive language direeted at the contents of this story, its tendency, and at the Jew's in general. For

II. 
tion hardly admits of a more favourable conclusion. However, it is evident that already in antiquity the facts had been distorted and represented in a false light. Interpreters who lived two hundred years or more after the events of the story occurred, and knew nothing about the real issue of those events, corrupted the text according to their own wrong interpretations.

The Alexandrian Jew who translated the story into Greek-at a time, however, before the Hebrew text was greatly corrupted-increased the perplexity. ${ }^{2}$ The Greek version, being a free and paraphrastic translation, naturally does not square with the original Hebrew text. But the differences touch also in a striking manner the proper names," a fact that cannot be due to paraphrase or exegesis. This phenomenon gave cause to suspect the authenticity of the Hebrew text. ${ }^{4}$ No other satisfactory

specimens of this kind, we may point to Carl Siegfried, in his commentary on the Book of Esther (in Nowack's 'Hand-Commentar zum Alten Testament', Göttingen, I901); Paul de Lagarde in his essay 'Purim', Göttingen, I887; G. Jahn in his book 'Esther', Leiden, I90I; see also note 26.

2 For the various Greek and Latin versions of Esther, cf. B. Jacob, 'Esther bei den LXX' in Stade's Zcitschnft für. Alttestancntliche Wisscnschaft, Giessen, I8̂go, pp. 241-98); L. B. Paton, Critical and Excgetical Connnentary on the Book of Esther, New York, 1908, pp. 29-47; P. Haupt, 'Critical Notes on Esther' in Old Testannent and Scmitic Studies in Mcmory of Willian Raincy Harper, Chicago, 1908, pp. 115-93); H. Willrich, 'Esther und Judith' in his Judaica, Göttingen, pp. I-28 , and G. Jahn's book cited above. The latter's Hebrew rendering of the Greek version is an amateurish biblical parody, but several of his observations deserve serious consideration.

3 See Jacob, l. c., p. 271 .

${ }^{4}$ Willrich. l.c. p. 15, seriously maintains that the Book of Esther was originally written in Greek and subsequently translated into Hebrew. There is no need to discuss this impossible view, as Willrich himself reluctantly concedes that the Hebrew text in several places exhibits more originality than the Greek (p. 19. n. I', and, moreover, confesses that he is unable to examine the linguistic character of the former. 
explanation for this odd divergence has been forthcoming. This difficulty is due to the fact that the action was placed in the wrong period. The difference between the two versions is easily explained as soon as we know that Egypt was not a part of the Persian empire at the period of these events. $^{5} \quad$ Hence the Egyptian Jews were not involved in the decree of Haman, and probably knew nothing about the events of Purim. ${ }^{6}$ The Alexandrian translator, who apparently was a learned and pious Jew, nay have lived in Palestine or in some other part of Syria among pious Jews who observed the festival of Purim. ${ }^{7}$ Having annually listened to the reading of the Book of Esther, he may have known it fairly well by heart, but could not remember correctly most of the proper names. After returning to his own country, he translated this story for the edification

5 Egypt revolted from Persia in the year 405 в.C.E., and remained independent for a period of sixty-five years. The latter, however, never recognized Egypt's independence, and frequently made futile attempts to reduce it to obedience.

${ }^{6}$ We thus fully agree with Willrich (l.c., p. 3), that the Alexandrian Jews had neither observed the festival of Purim, nor known anything about these events, before the story was ivritten in Greek. But we go still further and maintain, that even after they had become acquainted with this story, the Alexandrian Jews had no cause to celebrate the events of Purim. This testival was most likely introduced into Egypt by Palestinian Jews not long before the destruction of the Temple.

7 We must bear in mind that the pious of that period who strictly observed all religious ordinances represented only a small fraction of the Jews. The common people had abandoned the celebration of Purim long ago. Therefore, there was no reason for the author of the First Book of the Maccabees to refer to the latter festival, even if it had coincided with Nicanor Day, which it did not. Thus the objections of Willrich and all critics on this point are unfounded. Moreover, if Willrich were right in his assertion that the author of the First Book of the Maccabees assumes a decidedly hostile attitude towards the Pharisees, we could not expect this author to mention a festival observed solely by this pious sect. 


\section{of his countrymen. Not having had a Hebrew copy at} his disposal, and the translation not having been intended for liturgic purposes, but merely as a novel, he substituted numerous fictitious names for those in the original. ${ }^{8}$

"Jacob, l.c., pp. $266 \mathrm{ff}$., is certainly right in concluding that the Greek version is a free translation from the Hebrew text. But that alone would not account for the proper names, as Jacob (p. 270, n. I) freely admits, which with the exception of a few differ entirely from those of the Hebrew text cf. Paton, l.c.. pp. 66-71. Furthermore, a free translator would hardly omit passages without paraphrasing them, and would rather add than omit. Finally, it seems improbable that he should have paraphrased passages in a way which show the story in a different light, as he did in the passages containing the decrees of Haman and Mordecai. Jahn's sweeping assertion that the Greek version, on all points, resembles more the original than the Masoretic text, is not to be taken seriously. Willrich's view that the story was originally written in Greek (see n. 4), cannot be considered at all. But eren the present writer's explanation that the Greek translator did not have a Hebrew copy at his disposal when he made his translation, is not free from objections. It is incredible that the translator should not have remembered the name of Ahasuerus which occurs twenty-eight times in the story, the gentilic noun Agagi which occurs six times. and especially the passage: "And he thought scorn to lay hands on Mordecai alone; for they had showed him the people of Mordecai (3. 6) which is of vital importance for the understanding of the main event of our story. But in the opinion of the present writer, the Hebrew text underwent considerable changes after it had been translated into Greek. The Alexandrian translator was a pious, conscientious Jew and a good Hebrew scholar who, though paraphrasing the original text and substituting fictitious names, did not consciously omit anything. The omissions found are due to his exegesis. Thus, for instance, he could not understand the

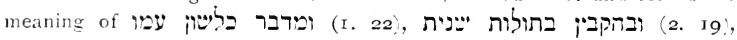

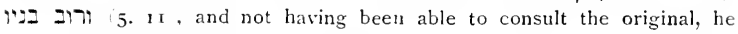
attributed the difficulties to his bad memory, and omitted them altogether. He may have known and applied the maxim : 'In doubtful cases, omission

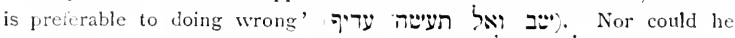

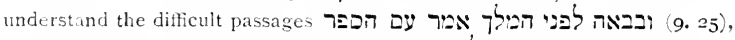

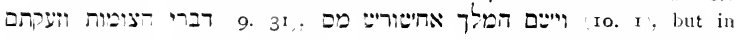
these cases, having been convinced that they were corrupt, he explained them differently. The fact, that so far none of the commentators have been able to explain the passages quoted satisfactorily, leaves no doubt that the 
The apocryphal writer went a step farther.' To his pious mind it seemed inconceivable that such a miraculous

Greek translator was a good Hebrew scholar. His memory, however, played him a trick as to the date of Esther's elevation. Since the tivelfth month played so important a part in the events of Esther, he believed tha. Esther's elevation took place in the same month. This wrong date proves again that he translated from memory; for if the original had contained this date, there was not the least reason for any interpolator to place that event in the tenth month. As for the decrees, however, the translator neither omitted anything nor paraphrased them, but presented an exact translation (sce Chapter IX). The passage 3.6 is undoubtedly due to a late interpreter who believed that Haman's decree was caused by his enmity towards Mordecai. We owe a debt of gratitude to the Greek translator who showed us that the original Hebrew author was quite inuocent of this stupidity. As to the name Artaxerxes in the Greek version, there is not the least doubt that the Hebrew text, even in a late period, contained the name ארתחשטשתא (see Chapter IV). The gentilic noun Agagi in the Hebrew text is not original either (see Chapter II).

9 The Greek version has at the end a subscription giving information about its authorship and date, which reads: "In the fourth year of the reign of Ptolemy and Cleopatra, Dositheus, who said that he was a priest and Levite, and Ptolemy his son, brought the foregoing letter concerning Phrourai, which they said was genuine, and that Lysimachus, son of

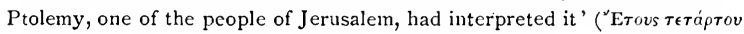

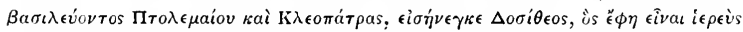

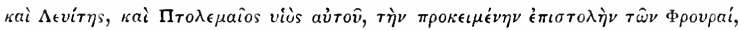

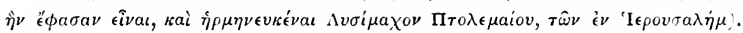
Jacob, l.c., p. 274, maintains that the king Ptolemy referred to in this subscription was Ptolemy VII, Soter II, Lathurus, who reigned II $7_{-8}^{-8}$ B.c.r., and thus the introduction of our story into Egypt occurred in the year I 4 , while Willrich. l.c., p. 4 f., contends that this king was Ptolemy XIV, and that the Book of Esther was composed in the year 48 B.C.E. However, both of them are wrong as far as the date of the Greek version is concerned. The subscription does not refer to the original Greek version of our story. Willrich himself points out that the Alexandrian scribe was not convinced of the genuineness of this Book and declined to take any responsibility for it (p. 3). Jacob likewise observes that expressions in this subscription indicate something like distrust (p. 276). This is of course the meaning

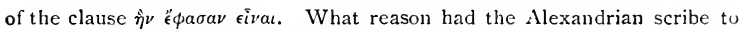
doubt the genuineness of this Book? The Alexandrian Jewish scholars to whom we are indebted for the preservation of so many apocryphlıl books 
event should be narrated unless abounding in religious sentiments, and he believed it to be a meritorious deed to improve upon its contents by representing the chief Jewish figures in the story as saints in Israel. This representation, though obviously contrary to the facts, was nevertheless generally accepted in ancient and modern times. Flavius Josephus, in his Antiquitics, moulded into his story of Esther both the Hebrew and Greek versions-though more of the latter than of the former ${ }^{10}$ - and considerable parts were not so liypercritical as to doubt the event of Purim. With the exception of Sirach, none of the apocryphal books has a subscription. Paton, l.c.. p. 3o, observes: 'A more serious objection to the genuineness of the subscription is the fact that it stands at the end of the long additions that seem to come from a different hand from that of the original translator'. However, this fact does not prove that the subscription is not genuine. There had been a well-known Greek version of Esther long before the arrival of Dositheus. But the latter brought another version, enlarged and interpolated by additions, and asserted that it was the genuine story of Esther translated from the Hebrew text, contending that the old version was defective. Therefore, the Alexandrian scribe who copied it rightly doubted his assertion, and declined to accept any responsibility for its truth. The original Greek version was undoubtedly made in a preMaccabaean period. This seems to be the true reason why the Book of Esther is the only historical book in the Greek Old Testament that has a subscription.

${ }^{10}$ We cannot agree with Jacob, l.c., p. 29I, that Josephus faithfully follows LXX, and Jahn, l.c., p. $\mathrm{x}$, is perfectly right on this point. Josephus calls Haman an Amalekite, which can be only a translation of Agagi of the Hebrew text, while the Greek version has instead of it Bovyaios. Then Josephus quotes the passage ויבו בעיניו, which LXX omits (see n. 8). Further, he gives the names of the two conspiring eunuchs בגתן ותרס, but appears to have read גבתן ותרס, which are omitted in LXX. Finally, in accordance with the Hebrew text, he states that the Jews slew seventy-five thousand Gentiles, while LXX knows only of fifteen thousand. Nevertheless, Josephus evidently preferred the Greek version for his purpose. He may have done so for linguistic reasons. A Jew translating the Old Testament into a foreign tongue would for the most part, if possible, make use of and adhere to the expressions of the already existing version. We can therefore understand why Josephus should have made use of expressions of LXX 
of the apocryphal additions, embellishing them with some exegesis, probably of his own. ${ }^{11}$ Origen ${ }^{12}$ declared the Greek version and its additions canonical. ${ }^{13}$

Though the use of the expression 'common sense' is a platitude, we cannot refrain from asserting that common sense has played no part in the interpretation of the Book of Esther, either in ancient or in modern times. The Rabbis, by their homiletic interpretations, contributed not a little to change this strictly historical narrative into an incredible fable. ${ }^{14}$ A few among them seem to have felt that there was something strange about this book. ${ }^{15}$ But, as a rule, the talmudic and midrashic sayings concerning the events of our story are not of the least value for exegesis, ${ }^{16}$ and in all probability were not intended to be. Notwithstanding this obvious fact, we, even in our critical age, still follow time-honoured talmudic interpretations

(Jacob, l. c., p. 262). On the other hand, his Antiquities was written for Gentiles, and therefore his intention may have been that his version of Esther should be in accordance with that written in Greek which might have been known to the critics of his period.

11 We do not agree with Paton, l. c., p. 39, that Josephus's additions are derived from an early form of Jewish Midrash, as no trace of them is found in the talmudic literature. His representation is a mixture of truth and fiction.

12 In his letter to Julius Africanus, $3 . \quad 13$ Cf. Paton, l. c., p. 34.

14 See especially Talmud Babli Megillah ro a-r6b, and cf. Paton, l.c., pp. 18-24 and 97-104.

15 See Chapter V.

16 The talmudic chronology concerning the date of our story is of no value at all. It is noteworthy that in Talmud, Midrash, and Targumim, Mordecai is represented as a contemporary of Zerubbabel (see Ezra 2. 2, \&.c.). But in Talmud Babli Menahot 65 a, we find the same Mordecai as the contemporary of Hyrcanus and Aristobulus. This fact appears to have escaped the notice of all critics. Willrich might have made it the basis of his theory that the Book of Esther was written 43 в.c. E. (see n. 8), if he had known it 
which obscure the right understanding of the book. Some exegetes are apparently over-fond of the rabbinical sayings. gleefully quoting and exploiting them for the purpose of stamping the story as legend. ${ }^{17}$ It is even possible that modern critics would hardly have hit upon the idea of seeing a legend in this story, if Talmud, Midrash, and Targumim had not embellished it with their exaggerated fables. ${ }^{18}$ It is regrettable to see that the strict line drawn by the mediacval Jewish commentators between 'exegesis'

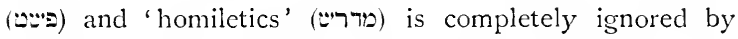
modern scholars. ${ }^{19}$ Nany of the rabbinical sayings dealing with Esther are of such a character that we cannot but believe that they were witty and homiletic remarks, partly to amuse, partly to exhort, the audience gathered around the Purim-table. ${ }^{20}$

Martin Luther's condemnation of the Book of Esther in his Table-Talks: 'I am so hostile to this book that I wish it dicl not exist, for it Judaizes too much, and has

17 Characteristic in this respect is Paton's Commentary. As a book of reference it is an exceedingly valuable work. But with all modern critics he holds the story of Esther to be a mere fable. In order to prove this point, he employs a peculiar method. His exegesis in the main is actually based upon the Talmud, Midrash, and Targumim. Though on every point he quotes numerous opinions, his general contention is that the only correct explanation of the points under discussion is given by the rabbis, and. since the facts, according to their explanations, could not have occurred, - i'rgo the whole story is not true. Cf. also Siegfried, l. c., p. I63, and Jahn. l.c., p. ${ }_{48 .}$

${ }_{18}$ Paton's observation (l.c., p. I8) is interesting: 'They (the Targumim) show a fine feeling for the Hebrew idiom and a e exceedingly suggestive to the molern interpreter'. So they are, as many theories of the modern interpreters have been suggested by them.

${ }^{19}$ Paton, l.c., p. 10o, does indeed point out the difference between and $: מ ר$, and nevertheless treats the latter as serious rabbinical exiegesis.

20 See Talmud Babli IIegillah 7 a. 
too much heathen naughtiness,' ${ }^{21}$ largely contributed to prejudice the mind of Protestant theologians in clealing with it. ${ }^{22}$

As early as the eighteenth century, scholars began to doubt the veracity of many facts described in Esther, as they seemed to be contradictory to the customs of the Persians recorded by Herodotus, and pronounced them unhistorical. ${ }^{23}$ The nineteenth and twentieth centuries actually teem with hypotheses concerning both the origin of Purim and the contents of our story." ${ }^{24}$ There is no exaggeration in declaring that it is easier to believe in the most improbable tales of antiquity than in these theories which are-with hardly any exception-flimsy, vague, and incredible. It is not necessary to discuss and refute them, as this has already been done-successfully and conrincingly-by Siegmund Jampel. ${ }^{25}$ But it is hardly fair to condemn the Talmud, as most of the modern commentators clo, for holding the Book of Esther higher than the Books of the Prophets. ${ }^{26}$ The Rabbis were not Bible

${ }^{21}$ In his works, edited by Walsh, VII, 194 ; XXII, 2080. On Luther's opinion, cf. A. P. Stanley, The History of the Jewish Chuich, Ncw York, 1879, III, p. 194. Paton, l.c., p. 96, observes that Luther's verdict is not too severe. Paton shares this attitude with numerous Protestant theologians who approach this subject with the pre-conceived idea of justifying Luther's verdict.

22 But there were a few Protestant commentators who, notwithstanding their veneration for Luther's personality, had the courage to blame him for his subjective judgement, as did Carl Friedrich Keil, in his commentary on Esther, p. 6ri3.

${ }^{23}$ For the literature of the eighteenth century, see Paton, l. c., p. II If.

${ }^{24}$ Cf. Paton, l.c., pp. 77-94 and I I I-I I 7 .

${ }_{25}$ Das Buch Esther, Frankfurt a. M., 1907, pp. 45 ff.

2; Emil Kautzs:h, in his Geschichte des Alttcstancntlichon Schriftums, Freiburg, I892, p. II 7 , vehemently denounces the Jews for holding the Book of Esther in such high honour, and considers it his duty as a Christian to protest against it. Similar opinions are expressed by Riehm, Wildebocr, 
critics, and believed in every syllable of our story. Therefore how could they have thought differently? Of what use would have been the Prophets, if the Jewish people had been exterminated? In their belief, the words of the Prophets and even the Pentateuch would have disappeared, if the Jewish people had not been saved by Mordecai and Esther. The Fathers of the Church, in declaring the Book of Esther canonical, reasoned exactly like the Rabbis : If there had not been Purim, Christianity would not have existed.

All the modern critics agree that our story was invented. Even Kautzsch, who is a moderate critic, is unable to find

Cornill, and others. They do not consider that Purim, according to the current conception, commemorates an historical event unequalled in the whole history of the Jews, their escape from complete annililation, and 'all that a man hath will he give for his life'; therefore it is natural that the Book that records this event should be held in the highest esteem among the Jews. Even from a purely ethical point of view, this Book is not inferior to the other Scriptures, as it teaches the great lesson, not found in the latter, that Providence may rule the destiny of man by natural circumstances, without visible intervention; and this lesson was the hope and comfort of the Jews whose existence was extremely precarious during the last two millenniums. It is wrong to see in the celebration of Purim the spirit of revenge. The Jews do not rejoice at the hanging of Haman, but at their own escape, firmly believing that their own destruction would have been inevitable, if Haman had been left alive. Scholars ought to be more objective, put aside their personal sentiments, and be able to comprehend also the Jewish point of view in dealing with this Book. It is regrettable to find views such as are expressed by E. Bertheau, that in this Book we find that spirit of Israel which does not trust in God, but in its own power, and which refused to embrace Salvation when it came to them (Die Bücher Esra, Nehemia, und Esther by Bertheau-Ryssel, Leipzig, 1887, p. 375. Paton, l.c., p. 97, observes: "With the verdict of late Judaism modern Christians cannot agree'. But is this verdict the only point of disagreement between late Judaism and modern Christians? Do not the latter regard the whole Pentateich as partly legendary, partly fabrication, and the secular history of Israel, in the main, untrustworthy? 
an historical nucleus in it, and considers it romance. ${ }^{27}$ Driver, who cannot be accused of prejudice, declares that 'it is not strictly historical, though it cannot reasonably' be doubted that it has a substantially historical basis. "28 There are only a few scholars who see in our story a really historical event. ${ }^{29}$ Paulus Cassel's commentary, ${ }^{30}$ notwithstanding its homiletic character and the numerous Christological remarks which have no bearing on the story, is full of sound judgement and contains a great many historical parallels and reminiscences which shed light on the events. It is a storehouse of real information. But it is extremely conservative, and sees in Mordecai and Esther the most splendid characters and heroes of Israel. One of the best attempts in recent years is Jampel's book cited abore. ${ }^{31}$ With a great array of arguments he tries to prove that all the events narrated in Esther might have happened under the reign of Xerxes.

In the present writer's opinion, however, all the commentators have been on the wrong track. The facts, as already stated, were misrepresented in ancient times, and modern interpreters have placed the action in the wrong period. If we may depend upon undeniably historical facts, we are justified in contending that the Book of Esther is strictly historical. We even maintain that, if this book had never been written, historians might have found out that at the period in which we place this action the Jews were threatened with complete extermination. The question is not whether this event did happen,

${ }^{27}$ Geschichte des Altt. Schriftt., p. 116.

28 An Introduction to the O. T., New York, 1898, p. 453.

29 See the bibliography of the conservative treatises, marked with $\mathrm{C}$, by Paton, l.c., p. 113 .

8. Das Buch Esther, Berlin, 1891

31 Sec 11. 25. 
but how the Jews escaped the danger. The solution of this problem is presented in the Book of Esther.

The main event of the story actually happened under Persian rule, though not in the reign of Xerxes. The Jews had indeed been in danger of extermination, though not in the sense generally understood. Many of the statements our story contains find their support in historical facts. As for the others, they are absolutely credible as far as they are original. For this book was considerably interpolated at a later period. The reason is not hard to explain. We must bear in mind that the real danger impending over the Jews was a tempest in a teapot: the whole excitement did not last more than four days, in Susa as well as in all parts of the empirc. ${ }^{32}$ IVith the death of Haman and the elevation of Mordecai, the condition of the Jews was no longer desperate. All the exegetes appear to have overlooked this fact. An event of this short duration did not make a lasting impression. ${ }^{33}$ Its commemoration was no doubt annually observed by pious Jews. But the common people, after a few generations, may have neglected it, or may have feasted on Purim without caring about the origin of the festival. ${ }^{3 *}$ They may have doubted the whole story, as Jews in prosperity soon forget troubles of former

$32 \mathrm{By}$ the splendid royal post under the Achaemeneian rulers (see Eduard Meyer, Geschichtc des Altcrthums, III, p. $66 \mathrm{f}$.), the overthrow of Haman and the elevation of Mordecai must have been known to the officials everywhere, a few days after the arrival of Haman's edict.

33 We shall see that there were religious persecutions, preceding Haman's decree, which lasted for several years. But these persecutions were of a sporadic character, as the rank and file of the Jews had not been affected by them (see Chapter VI).

4 Numberless Jews in the present age are doing exactly the same, in enjoying the customary dishes prepared for certain festivals with great relish, without caring in the least for the religious character of the latter 
day's, and as the danger could not reasonably be accounted for, it was looked upon as an incredible tale. The Jew's did not remain untouched by the scepticism prevailing in the Alexandrian age. Living unmolested under the mild sway of the Lagidae and the first Seleucids, the Jews did not believe that a man like Haman had ever existed, or that a king should have decreed the extermination of their ancestors. The Book of Esther became popular with them under the rule of Antiochus Epiphanes (175-16+ B. C. E.) and his successors, when they met everywhere with numerous men of the type of Haman intent upon destroying them. In those times of terror they looked for comfort to the Scriptures. They found only one book in which a similar event had been recorded-the Book of Esther. At that late period the actual events under Persian rule which had almost caused the destruction of the. Jewish people were no longer known. Being now popular, this book became the favourite theme of the preachers and an object of special study. The teachers who had to explain it to the people made wrong interpretations, which subsequently were incorporated into the story. We may well assume that for the purpose of impressing upon the people the necessity of being united, and exhorting them to fight one for all and all for one, the preachers in their sermons took as their theme the decree of Haman, and explained to their congregations that the latter intended to exterminate all the Jews on account of a single individual. We know that the Jews of that period were unwilling to resist their enemics and to fight for their independence, and their leaders had to use any means for inducing them to do so by arousing their fear and hatred. To encourage the people to fight 
their enemies without fear, the preachers told their congregations about the heroic deeds of their ancestors, who killed 75,000 men in one day without losing a single man. The Edomites, the hereditary enemies of Israel, were no less hostile at the time of the Maccabees, until conquered by Hyrcanus. Therefore Haman may by some witty preacher of the time have been made a descendant of Esau, by changing the gentilic name הבגי into האגי Paul Haupt is partly right in observing: 'The spirit of revenge that breathes through the Book of Esther and manifests itself in the celebration of Purim seems perfectly natural as soon as we know that the book was written during the period of the Maccabees, after the Syrians had committed unspeakable atrocities in Judaea.' ${ }^{36}$ These interpretations were later inserted into the Hebrew text. The Alexandrian translator was unfamiliar with them. ${ }^{37}$

When we understand the historical events which form the background of the story, the social and moral state of the Jews of the period, and the psychological motives of the chief figures, our story will be viewed in a different light: Mordecai and Esther will lose their nimbus, Haman his terror, and Ahasuerus's decree against the Jews will no more be ascribed to his imbecility. Words or passages

85 See n. 8.

so Purin, Baltimore, 1906. This paper contains numerous ingenious suggestions. However, the theories advanced there for the origin of Purim and for the prototypes of Ahasuerus, Haman, Mordecai, and Esther are impossible, as Paton, l.c., pp. 80-82, has already pointed out. But $\mathrm{P}$ Haupt is the only modern critic who is absolutely fair in his treatment of this story. However, on some points he goes too far. The Jews in post-exilic times were never persecuted on account of their nationality; thus the persecutions of the Russian Jews do not present a parallel to those described in the Book of Esther.

37 See Chapter II. 
contradictory to our interpretation will easily be recognized as later additions. But we must draw a line between additions and changes due either to exegetes or to errors of copyists and changes owing to circumstances over which the Jews had no control. The name Ahasuerus, which is undoubtedly identical with Xerxes, had been substituted for the real name of the king, for obvious reasons. In the Eastern countries under the rule of the Arsacids, this change was made rather early; in the West at a later period, at the time of the fixing of the Canon. This fictitious name led the modern commentators astray. Those who gave credence to the story contended that Xerxes was quite capable of doing all the silly actions ascribed to Ahasuerus, and made more or less successful attempts at reconciling these events with the historical facts recorded by Herodotus. But the overwhelming majority of exegetes rightly rejected these forced interpretations. There is, indeed, no room for doubt that the Ahasuerus of Esther cannot be identical with Xerxes, as we hope to prove in the third chapter. 


\section{CHAPTER II}

The improbability of Mordecai's genealogy-His access to the haremHaman's genealogy - The etymology of his proper and gentilic names.

BEFORE proceeding to outline our own conception of the story of Esther, we consider it necessary to investigate some objections of a general character, though they have no bearing on our own interpretation. These objections, raised by all modern critics, appear to throw doubt on the veracity of the author of the book, and to betray a certain tendency to present an artificial contrast between two hostile races. Though others have already dealt with this subject, their conclusions are not quite satisfactory.

(s) There is a chronological question of the highest importance. The author states: 'There was a certain Jew in Shushan the palace, whose name was Mordecai, the son of Jair, the son of Shimei, the son of Kish, a Benjamite; who had been carried away from Jerusalem with the captivity which had been carried away with Jeconiah king of Judah, whom Nebuchadnezzar the king of Babylon had carricd away'. According to this statement, Mordecai, as fellow captive of Jeconiah (= Jehoiachin), was carricd into captivity in the year 597 b.C.E. Shall we then believe that 123 years later he became prime minister, in the 12 th ycar of Xerxcs' reign, in the year $+7+$ li.C.E. ? But those who raise this question do not entertain any doubt that Kish, the ancestor of Nordecai mentioned in his genealogy, is identical with the father of Saul, the first 
king of Israel. Accordingly, the clause "who had becn carried away' (איטר הגלה) can only refer to Mordecai, and not to Kish. However, this identification is by no means certain and is indeed emphatically denied by Ibn Ezra. ${ }^{1}$ Then there is no reason why this clause should not refer to Kish and not to Mordecai." Wildeboer, ${ }^{3}$ Siegfried, ${ }^{4}$ and many. other modern commentators refuse to accept this explanation, as it would be against the Masoretic division, which places this clause at the beginning of the following verse. But they themselves often completely disregard the Masoretic text, and would be correct in doing so here. Cassel is right in observing: "One cannot imagine it possible that biblical commentators should have hit upon

1 Ibn Ezra ad locum remarks: "If Kish, mentioned in Mordecai's genealogy, referred to the father of Saul, the author of Esther would have ו"אילו היה אבי '

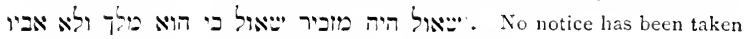
of this reasonable observation by the modern critics.

2 The relative clause

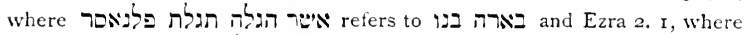

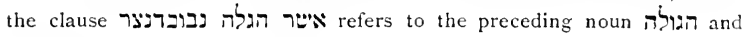
not to בני המרינר תוברינר.

${ }^{3}$ Die fünf Megillot, in Martis Kurzer Hand.Commentar zun Alien Tistanent, Freiburg i. B., I898, 180.

4 In his commentary on Esther, l. $c$., p. I 8 . We must consider that the chronological knowledge of the Masoretes was no more exact than that of the rabbis, who consider Mordecai a contemporary of Zerubbabel see Chapter I, n. I6) and place the reign of Ahasuerus within the seventy years of the Babylonian Captivity. We may further presume that the Masoretes accepted in good faith the talmudic interpretation of the name

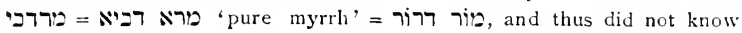
that Mordecai was a purely Babylonian name. Therefore the Masoretes had no reason not to refer the clause איטר הגלה to Mordecai. The latter might have been carried away into captivity in his childhood, and was still alive in the period of this story. Besides, the Masoretes may have earnestly. believed that Kish in Mordecai's genealogy referred to the father of Saul. 
such a monstrosity, in referring the statement of Jeconiah's exile to Mordecai.' 5 Moreover, the purely Babylonian name that Mordecai bears evidently shows that the author did not intend to say that he was born in Jerusalem. We would have to assume that the Persian-Jewish author ${ }^{6} \mathrm{did}$ not know that Mordecai was a Babylonian name, at a time when the cult of Marduk was still in existence. IVildeboer asserts that the author clearly indicates that it was not his intention to give a real genealogy. ${ }^{7}$ There is not the least ground for such an assertion, as the identification of Kish with the father of Saul is at least doubtful. Siegfried remarks; 'By the brevity of the genealogy, the author, in omitting a few members of it, skips over the times of Saul to Kish.' But did the author omit merely a few members

5 Das Buch Esther, p. 51.

5 Seeing that our author was well informed on Persian manners and institutions, a fact that is almost generally conceded, and was well acquainted with the Persian language, a fact that only those critics deny who are not authorities on Persian philology, as Jampel truly remarks, we may safely assume that the author was not a Palestinian Jew. P. Haupt Purim, p. 3 ; Critical Notes, p. 116) believes that he was a Persian Jew. In the present writer's opinion, however, the Book of Esther was written in Babylonia (see Chapter V); and at that period the Babylonian Jews were just as well acquainted with Persian manners, institutions, and language as were the Persian Jews. But Haupt from his own point of view must assume that the author was a Persian Jew, since he contends that Esther was written after the Maccabean period, and at that time Persian Jews only could have been so thoroughly acquainted with Persian manners, institutions, and language.

7 Paton, l.c., p. 167 , concedes that Jair may have been the father of Mordecai. The reason for his concession seems to be, because he cannot disccver an ancient bearer of this name among the Benjamites. Shimei, however, cannot have been the father of Jair, since there once existed a man belonging to the tribe of Benjamin whose name was Shimei son of Gera (2 Sam. 16.6. Kc.). Nor can Kish be the father of Shimei, since the same name was borne by the tather of Saul. But there were four bearers of the name Shimei belonging to the tribe Reuben a Chron. 5. 4 , Simeon 
of this genealogy? From Mordecai to Kish would be at least fourteen generations, ${ }^{8}$ and the author enumerates only three of them. But it is not impossible that the genealogy is not quite complete, and that between Mordecai and his exiled ancestor Kish there were a few more generations. IVe shall see that according to our conception the events of our story occurred about two hundred years after Jeconiah's exile, and we may reasonably doubt whether only three generations could have intervened between this period and that of Esther. For such a possibility we may point to Ezra's genealogy, in which his immediate ancestors are omitted. ${ }^{9}$ A similar omission may be inferred in Mordecai's genealogy. We may suggest that they were men of a type whose names the biblical authors deemed unworthy to perpetuate, probably idolaters. ${ }^{10}$

ibid. 4. 26, 27), Levi (ibid. 6. $1_{4}$ and 28), besides two others of the tribe of Benjamin (ibid. 8. 21 ; 1 Kings 4. 18). So also we find two bearers of the name of Kish, both Levites (I Chron. 23. 21, \&c.; 2 Chron. 29. 12). The genealogy of Mordecai given in the Second Targum, on which the contention of the modern critics is evidently based, is of course pure fiction, and badly invented, as from Mordecai to Kish it enumerates eleven generations, hut from $\mathrm{K}$ ish to Benjamin twenty-eight generations.

8 We find fourteen generations from Kish to the return from the Babylonian Captivity (I Chron. 8. 33-8). The same number we find from Zadok to Joshua (ibid. 5. 34-4I).

${ }^{9}$ Cf. Ezra 7. I ; I Chron. 5. 4ò. Bertheau-Ryssel, in his commentary on Ezra, p. 88, believes that the author merely intended to show us that Ezra was a lineal descendant of high-priests, and therefore omitted his immediate progenitors who were not high-priests. But this explanation is improbable. The line of the high-priests was well known, since Joshua and his descendants still held this office. What we want to learn is Ezra's relationship to this high-priestly line, ard this point is altogether omitted.

1' We shall show (Chapter V) that IIordecai's family does not appear to have been strictly religious, and may have belonged to those noble Jewish families which continued idolatrous practices in Babylonia, before its conquest by the Persians. The same may hold true of numerous priests, 
(2) The author further states: 'And Mordecai walked every day before the court of the women's house, to know how Esther did, and what should become of her'. This statement is denied by most of the modern commentators, who regard as impossible that Mordecai should have been permitted free access to the harem without being a eunuch. ${ }^{11}$ We freely admit that this is impossible, but impossibilities sometimes happen. One could never believe that prominent scholars and grammarians who know Hebrew pretty well should raise such an objection. The author does not say: "Mordecai walked in the court of the women's house' (מרדבי מתהלך בהזצר בית הניטים), but 'before

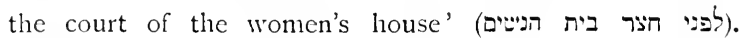
Mordecai did not enter the court of the harem, which no doubt was surrounded by a high wall, but walked outside of it, to inquire of the cunuchs about his adopted daughter. Many other Persians who had daughters there most likely did the same. Siegfried's sarcastic remark,

though Ezekiel seems to bear testimony that the 'sons of Zadok' kept themselves free from idolatry (Ezek. 44. 15). Some of them may have become corrupted after Ezekiel's death. The intermarriage of the sons of the high-priest Joshua with Gentiles shows that even the priests were not above reproach. Now there is a talmudic maxim that the names of irreligious men should not be recorded, based upon the verse ושם רשעים ' ' the name of the wicked shall rot' (Prov. 10. 7). This verse is interpreted דלא פסקינן ביטתויה, that we should not bring up their names Talmud Babli, Yoma $38 \mathrm{~b}$. Such a conception is not purely rabbinic, but is found also in the Bible; cf., for instance, Exod. 17. 14; Deut. 32. 27 ; Isa. 26. I4; PS. I12. 6, Sic.

11 Th. Noldeke (Encrclopatdia Biblica, I40r), Wildeboer, Siegfried, in their commentaries, J. D. Prince (Jewish Encyclopaedia, under 'Esther', and many others. Haupt Critical Notes, p. 135) suggests that Mordecai may have been a eunuch. But the passage: 'and speaking peace to all his seed', clearly indicates that Mordecai had children, and we would have to assume that he became a eunuch after he had raised a family. 
'The author does not trouble himself about the difficulty, how Mordecai could have shown himself in the court of the harem and converse with Esther', is characteristic of his commentary. ${ }^{12}$ Besides, Esther at the time of this event had not yet been in the real harem that was under the supervision of Shaashgaz. The virgins under Hegai, not yet being concubines, may have enjoyed the liberty Esther of communicating with their relatives. ${ }^{13}$

(3) The author finally states: 'After these things did king Ahasuerus promote Haman the son of Hammedatha Esther the Agagite, and advanced him, and set his seat above all the princes that were with him'. The commentators are by no means wrong in their arguments concerning the representation of Haman as descendant of Agag, in calling attention to the following points: (a) The statement that Haman was a descendant of Agag is in itself quite improbable. (b) It is incredible that the Persians should have tolerated the rule of an Agagite prime minister. (c) The representation of a racial contrast between the Benjamite Mordecai and his antagonist the Agagite Haman, renewing the ancient hereditary enmity between the Benjamite Saul and the Amalekite Agag, is too artificial to be regarded as an historical fact. ${ }^{14}$ The critics, however, do not seem to perceive that their arguments are

12 The present writer is gratified to find that Haupt had already called Siegfricd to account for his distortion of the truth, in observing: The narrator, it may be supposed, knew more about Oriental manners and customs than did Siegfried. The author did not overlook the difficulty, but Siegfried overlooked 'לפ', (Critical Notes, p. 135' . However, Siegfried merely repeated an old objection found by many earlier commentators.

13 Paton, $l$. c., p. I8o, is also of the same opinion that the concubines under the custody of Shaashgaz were probably kept under stricter surveillance.

14 Wildebocr, Sicgfried, \&c., \&c., and so also Paton, l. c., p. $7^{2}$. 
not directed at the veracity of the author, but at a talmudic interpretation. They would never have thought of that contrast if Talmud, Midrash, and Targumin had not dwelt at length on it. It is well known that it is a pet fancy of the rabbis to represent all the enemies of the Jews, even Rome, ${ }^{15}$ as descendants of Esau - who had been wronged, but never committed any wrong in his lifetime-and it is still customary to designate any persecutor of the Jews as Esau. Characteristic in this respect is the Second Targum, which contains a complete genealogy of Haman, in which we find Greek and Latin names of oppressors of the Jews, and among them occur also those of king Herod and his father Antipater. ${ }^{16}$ Hence it is obvious that the talmudic interpretation of $A g a g \bar{z}$ is merely homiletic and should not be taken seriously.

However, for the sake of argument, let us admit that the gentilic noun $A g a g \bar{z}$ actually means 'descendant of Agag', and that accordingly the narrative indeed implies a contrast between two hostile races. The question now arises whether the narrative would have been less comprehensible without that contrast. Would there be a missing link in the narrative, if the gentilic noun Agagi were entirely omitted? This question must certainly be answered in the negative. Nobody would presume to assert that the Greek version of Esther is not quite intelligible because it knows nothing about a racial contrast between Haman and Mordecai. This version further clearly furnishes proof that the gentilic noun האגנ could not have been in the original Hebrew text, but was due to some interpreter, as

15 See Lewy's Handwörterbuch zum Talmud und Midrasch, under 'Edoin', and cf. Rashi on the passage ולאם מלאם יאפיץ (Gen. 25. 23).

${ }^{16}$ For the genealogy of Haman, see Cassel, l. c., p. 83 f. 
already suggested in Chapter $I,{ }^{17}$ who intended to represcnt that racial contrast, after the story inad been rendered into Greek. The Alexandrian translator was undoubtedly well acquainted with the Scriptures and thus knew who Agag was. If he had found the gentilic noun האג' in his Hebrew text he certainly would have rendered it 'A yayaios, not Bovraios. ${ }^{\text {s }}$ There can scarcely be any doubt concerning the meaning of the latter term. The Persian word baga $=$ 'God' is found in numerous Persian personal names, as for instance, Bagacaus, Bagoas, Bagopates, Bagophancs, Bagosaces, \&c. ${ }^{19}$ Therefore, if we find Bovyaîos as gentilic name of a Persian, in a narrative the scene of action of which is Persia, we may reasonably see in it the Persian element baga and assume that Bovraios $=B$ ayaios. The same element no doubt occurs in the names of the eunuchs, בגתי בגתא. The latter is rendered in the Greek version $B o v \gamma \alpha \theta \dot{\alpha} \nu=B \alpha \gamma \alpha \theta \alpha \dot{\nu}$. Paul Haupt's explanation of the Greek Bovyaios as a Homeric term, 'braggart' is far fetched. ${ }^{\circ}$ The fact that the Alexandrian translator was forced to substitute fictitious names for the genuine Persian names in the Hebrew text, evidently shows that he did not understand the Persian language. Nevertheless the gentilic noun Bovyaios is genuine Persian. Therefore we may safely assume that the equivalent of this term in the Hebrew original was not האגני, הבג' the Bagoan'. A similar

17 Cf. Chapter I, n. 8.

${ }^{8}$ Or the Alexandrian translator might have rendered it $\Gamma \omega \gamma$ aîs, as did Lucian. The name Hegai usually rendered $\Gamma a i$ in the Greek version, is

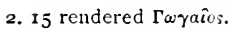

${ }^{17}$ See Iranisches Namenbuch by Ferdinand Justi, Marburg, I895.

20 Purim, p. 12; Critical Notes, p. 141. Haupt evidently overlooked that the element Bov $\gamma^{a}$ is also found in the eunuch's name Bov $\gamma a \theta a v$ (instead of Ilarbonab, 8. 9 . 
name is borne by one of the Jewish leaders who returned from exile with Zerubabel, בגו, which the Septuagint correctly renders Bayovaí. ${ }^{11}$

Moreover, how could the Hebrew author have intended to say that Haman was a descendant of Agag? He undoubtedly was familiar with the Scriptures, and must have known that Agag's whole tribe had been exterminated by Saul; Agag himself was slain by Samuel, ${ }^{22}$ and the other tribes of Amalek had been destroyed in the time of Hezekiah. ${ }^{23}$ Is it conceivable that a Jewish author would have dared to contradict the Scriptures? Now it has been suggested that the author's intention in designating Haman as an Agagite was merely to characterize him as an inveterate persecutor of the Jews. ${ }^{24}$ But also this interpretation is improbable. The fact that Saul and the people, notwithstanding the divine command, spared Agag and did not wish to slay him, indicates that Agag personally was by no means a ruthless oppressor of Israel, but suffered mainly for the many wrongs committed by his ancestors and his tribes, as the Bible indeed informs us.. ${ }^{-5}$ Thus there is no reason why just his name should have been selected for the formation of an appillatizum, given to Haman, as a great enemy of the Jews. If that was the intention of the author, he certainly would have

21 Ezra 2. 2, \&c.

22 I Sam. 15. 134.

23 x Chron. 4.43.

24 So Cassel, l.c., p. 84 .

${ }_{25}$ Graetz, in his History of the Jca's, vol. 1, p. 91, states that the Amalekite king Agag appears to have caused great trouble to the tribe of Judah in the days of Saul. Now there is no doubt that the Amalekites made predatory incursions into the Jewish territory on all occasions. They did the same in the periods of Ehud Judges 3. 13 and of Gideon (ibid.6.3). The Midianites did exactly the same. The other neighbours of Israel, as the Philistines and Ammonites, were no less hostile to the Israelites than the Amalekites. 
called Haman Pyל ${ }^{26}$ We may therefore contend that there is no truth whatever in this interpretation, and that in the two words אגני אגe merely have a similarity of sounds which is frequently deceptive. How fanciful identifications of this kind are, we can illustrate by identifying "אגי with the Babylonian word agagu, "to be powerful', the Arabic أجَّاج 'burning', 27 or even with Greek a'y $\hat{\omega} \gamma \alpha$, 'leader.'

It has further been suggested, by Paul Haupt, ${ }^{23}$ that the original reading of Haman's epithet was 'האי = Gagi, in the sense of 'Northern barbarian', which was afterwards changed into אגי. This suggestion is based upon the Lucianic recension, which renders Haman's epithet ' Twyaios. But Lucian's recension was made towards the end of the third century C.E., and is either, as some contend, an independent translation from the Hebrew, or a recension of the old Greek version, in which the Hebrew text was used as well. ${ }^{29}$ Josephus ${ }^{30}$ and the Talmud undoubtedly read אג, and therefore it is exceedingly improbable that Lucian should have found in his Hebrew original the reading גיאג. Furthermore, it is highly improbable that a gentilic noun $G \bar{a} g \bar{\imath}$, derived from 2 , should ever have been written with $N$. Lucian may have found in his Hebrew text the reading 's, but being well aware of the fact that Haman could not have been a descendant of Agag, considered this term either a scribal error or an

${ }^{25}$ Similarly Cassel, l.c., p. 84 .

27 The present writer, offering these etymologies ad absurdum, was surprised to see them seriously suggested by H. Winckler (Altoricintaische Forschungen, II, p. 381 ).

${ }_{8}$ Purim, p. I4; Critical Notes, p. 14 I.

29 See Jacob, l.c., p. 260 , and Paton, l.c., p. $3^{8}$.

30 Josephus states that Haman was an Amalekite (see Chapter I. n. Io . 
arbitrary corruption on the part of the Jewish scribes for the purpose of representing a contrast between the Benjamite Mordecai and the Agagite Haman, and therefore believed that the original term was 'ג, which he rendered Twyaios. He even may have seen in the rendering Bovyaios of the Alexandrian version a corruption from Twyaios or Tovyaios. But even according to Lucian's reading we have no reason for the assertion that the author's intention was to represent Haman as a northern barbarian. The land $i d$ in Ezekiel's prophecies, ${ }^{31}$ identical with Giga in the Amarna Letters, ${ }^{32}$ was undoubtedly. situated in Armenia. ${ }^{33}$ We know that this country became a part of Persia proper, where the Zoroastrian religion and the Persian language had been successfully introduced, ${ }^{3 t}$

31 Ezek. 37. 2, \&c.

${ }^{32}$ See H. Winckler's Tell-El-Amarna Letters, No. 5 (in Eb. Schrader's Keilinschriftliche Bibliothek, vol. V).

${ }^{33} \mathrm{Gog}$ is designated by Ezekiel : 'chief prince of Meshech and Tubal'. These nations are of course identical with the Mushki and Tabal. They belonged to the Hittites (see A. Jeremias, The O. T. in the light of the Ancient East, vol. I, p. 280). We know that Tabal dwelt in Lesser Armenia (cf.ibid., p. 28I), and the Mushki are everywhere in the Cuneiform inscriptions mentioned in connexion with Tabal and Urartu. In Xerxes's army against Greece we find both nations, Tabal and Mushki, under the names of Tibarenians and Moschians under one commander (Herodotus VII, 78). These nations are mentioned in Ezekiel with Togarmah, identical with Tilgarimu. which, according to Dillmann, Kiepert, and Friedr. Delitzsch, is situated in South-Western Armenia (Del., Paradies, p. 246). The principal state of these nations was Magog, which comprises Eastern and Western Armenia (ibid., p. 247). Now the Hittites, to which evidently all these nations belong, were by no means barbarians, if we may judge by their monuments. Thus the assertion that Gog is a term used for 'northern barbarian' is unfounded.

34 Cf. J. Marquart's Fundanente Israclitischer und Jïdischer Gischichte, Göttingen, 1896 , p. 38 , and Hastings's Encyclopaedia under 'Armenia' (Zoroastrianism). 
and where the P'ersian nobles possessed large estates.:5 Therefore, Haman could have been of purely Persian origin and nevertheless be designated by the gentilic noun i, because he was a native of the land of $G \dot{o g}$.

Howerer, for the question, whether Haman was a foreigner or a Persian, we must consider, beside the gentilic ' 2 , his orn name and that of his father. We know what a prominent part Haoma (Hōm) plays in the Zoroastrian religion. It was the name of the guardian angel and of the holy plant used for sacrifices. ${ }^{36}$ The names of Haman and his father Handatha, 'given by Hōm ', are undoubtedly connected with Haoma. Cassel is even inclined to suggest that such holy names could only have been borne by priests, and that Haman and his father were Magians, ${ }^{37}$ who were a tribe of the Medes. But Cassel goes perhaps too far in this assumption. We cannot see why names like Bagadatha 'given by God', and Mithradatha. 'given by Mithra', should be less holy than the former, and yet there are bearers of such names who did not belong to the priestcaste of the Magians. Such names could even have been borne by foreigners, as we see that one of the Jewish leaders bore the name "ב, which, as has been suggested, ${ }^{38}$

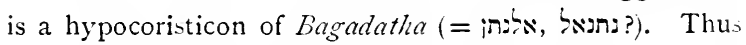
the Persian names which Haman and his father bore are no evidence that they were not of foreign descent. But

35 See Eduard Meyer, Geschichte, III. p. I38.

${ }^{36}$ Cf. A. V. Williams Jackson's Zoroaster, New York, 1899. pp. 25, 50, and Geldner's article 'Zoroaster', in the Encyclopaedia Britannica, I Ith ed.

37 Cassel, l.c., p. 82.

${ }^{38}$ A. Wellhausen, Israelitische und Jüdische Geschichte, p. r 20. His suggestion that Bagadatha is a translation of Jonathan is improbable. Ed. Meyer (Entstehung des Judentuns, p. ${ }_{57}$, n. 2 ; thinks that Bagadatha and Baroi are distinct Persian names, both derived from baga. 
being a naturalized Persian, it is doubtful whether Haman's foreign descent would have lowered him in the eyes of the Persians and debarred him from occupying a high position. ${ }^{33}$ Now it is true Humma or Umma is the name of an ancient Elamitic deity which occurs in numerous Elamitic proper names," and we might see the same divine name in the names Haman and Handatha. We could therefore contend that Haman was by origin an Elamite. But who knows whether the divine elements Him and Humma are not identical? It would be a curious coincidence if $H \bar{o} m$, one of the chief deities in the religion of the Persians whose capital was in Elam, should not have some connexion witi Humma, one of the chief Elamitic deities. ${ }^{41}$ However, for the question under consideration it is quite irrelevant whether Haman was of Persian or Elamitic

${ }^{39}$ Herodotus VI, 4r, states that the children of Metiochus son of Miltiades were accounted Persians, because their father had married a Persian woman.

${ }^{40} \mathrm{Cf}$. the Elamitic proper names Ummanigash, Unmanaldasi, Toumman, \&c. But it is strange that we do not find the name of this deity among the names of the twenty gods enumerated by Aslurbanipal cf. $K B$, ll, p. 205. However, the element amman is found in the compounded

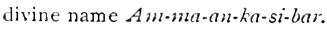

${ }^{41}$ Haoma, generally considered to be identical with Vedic Soma (cf. Geldner, l.c.): the Persians did not take over this deity from the Elamites. We may only question whether there were not early relations between the Elamitic and the Vedic religions. The racial affinity of the Elamites is still an open question. They may have been related to their neighbours, the Kassites. Now it has been observed that some of the Kassite names bear most striking resemblance to those of the Hittites, and especially to those of the stock of Mitani (ct. Clay, Personal Nants of the Cassite Pcriod, pp. 44, 45. It has been further demonstrated that there were Aryan elements among the Hittite-Nitanni, as the Aryan deities Mira, Vama, Indra, Nasatya oicur in the Hittite documents found by $\mathrm{H}$. Winckler in Boghaz-kui Mitt. d. Doutoch. Oricnt. Ges., Dec, 1907, p. 51). Thus there is a possibility that Humma is of Aryan origin and identical with the Vedic Soma. 
origin, as at the period of our story there was hardly any difference between Persians and Elamites. ${ }^{4}$

But the question whether the Persians would have submitted to being ruled by a foreigner-a question which concerns Mordecai's position as well as that of Hamanwe can by no means answer in the negative, if it is true that Bagoas, the most powerful prime minister under Artaxerxes III and his successors, was a native of Egypt. ${ }^{43}$ Thus the premises from which the conclusions under discussion are drawn do not stand the test of impartial research, and the objections of the modern critics do not invalidate the contention that the Book of Esther is historical.

42 If Ahasuerus is to be identified with Xerxes, we may doubt whether the Elamites, who had rebelled against Darius I, and set up a king of their own (Behistun Inscription, Col. I, 29), were in the short period of about forty years completely assimilated to the Persians. But if our story happened much later, we may reasonably assume that at that time there was hardly any difference between Persians and Elamites.

${ }^{43}$ See Justi, Iranisches Namenbuch, under 'Bagoas'. However, the whole argument concerning the descent and the name of Haman is absurd, and it would be a waste of time and of labour to deal with it seriously, if it were not for the fact that all modern critics attribute to it so much importance and base upon it mythological or historical theories. Haman might have been of Amalekite origin and be nevertheless to all intents and purposes a real Persian. His ancestors might have lived in Persia for a long period, though his foreign descent was still known to the Jewsa fact that is of course quite improbable. but not impossible. 


\section{CHAPTER III}

The author of Esther as an historian-The date of these events - The extent of the Persian empire-The coronation festivities-Xerxes' war with Greece-His queen Amestris-The Jews outside of the Persian empireThe diaspora-Jewish persecutions in post-exilic times-The improbability of Haman's decree-Xerxes' character-His attitude towards the JewsThe new possessions of Ahasuerus.

IF a book contains anachronisms, as do the Books of Daniel, Tobit, and Judith, we may cloubt its historica! character, since its author could not have committed errors of this kind if he had known the history of the period in which the events are said to have occurred. The author of the Book of Esther, however, is not guilty of anachronisms, and was well informed on Persian manners and institutions. Therefore, we have no reason to assume that his knowledge of Persian history was inferior to that of the Greek writers of his period. From this point of view we shall investigate the events of our story, and demonstrate that the Ahasuerus of Esther cannot be identical with Xerxes.

Esther I.I.

(1) The story opens: 'Now it came to pass ${ }^{1}$ in the days

1 The Imperfect with waw consccutivum in $ו$, that implies a precedins verb in the Perfect, and is always used in continuation of a historical narrative, is here correct. The Book of Esther continues the history of lsrael, and thus forms a part of the other historical Books. The author does not intend to write the story of Ahasuerus, and presupposes that the reader is acquainted with the earlier history of this king, as BertheauRyssel, l.c., p. 379, strangely explains. Nor is the use of the Imperfect with waw consccutivum an imitation of the older histories, designed to suggest that Esther belongs to the same class of literature, as Paton, l. c., p. 1<0 assumes. 
of Ahasuerus, this is the Ahasuerus who reigned from India even unto Ethiopia, over a hundred and seven and twenty provinces'.2 The intention of the author evidently was to give to the reader exact information concerning the ling under whose reign the events narrated occurred." He assumes that several Persian kings bearing that name are known to his readers-as Ibn Ezra explains-and therefore fixed the date by the additional remark, that the Ahasuerus of the story was that king who ruled from India to Ethiopia, and no other king bearing the same name, for the dominion of the other did not extend so far. If this king was Xerxes, there was no need to fix the date.

(2) The king of the story did not lose any of his hundred and twenty-seven provinces during the whole period of his reign. But Xerxes did lose a considerable part of Asia Minor, in the sixth and seventh years of his reign, as we

2 The identification of the term מינינה with 'satrapy' is decidedly

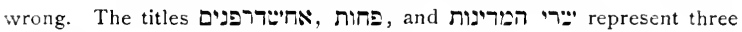
classes of officials. The first were rulers of satrapies, as is well known, the second were governors of smaller territories, and the last were the governors of districts. The word מדיפה is a derivation from ${ }^{\prime}$ ' to judge', and means 'the seat of a judge, judge's circuit'; and therefore in Arabic and Syriac the terms for 'city' are was a Ilcdinah, not a satrapy. In a later period, Judea and Galilee were considered two different מריפות. Accordingly, there is no discrepancy between the author of Esther and Herodotus. who states that Darius I divided the Persian empire into twenty satrapies III, 3). Cf. Keil, ?. c., p. 616, and Paton, l.c., p. 123 .

3 Wildeboer, Driver, and others deduce from this passage that the reign of Ahasuerus lay in a past somewhat distant at the period of the author. But we ought to give the author credit for more sense. The latter evidently intended to present this story as an ancient document. Hence it is improbable that he should have expressed himself as if he intended to show that those events occurred in the distant past. Therefore it is obvious that his sole intention was to fix the date of that ruler under whose reign the story occurred. 
know that most of the Greek territories became independent after the battles of Salamis, Plataea, and Mycale. ${ }^{*}$ This fact seems to have been overlooked by all the exegetes.

Esther I. 2,3 .

(3) The story continues: 'In those days, when the king Ahasuerus was sitting on the throne of his kingdom, which was in Shushan the palace, in the third year of his reign, he made a feast unto all his princes and his servants; the power of Persia and Media, the nobles and princes of the provinces being before him'. In these passages the author seems to contradict himself. The clause, "when the king Ahasuerus was sitting on the throne of his kingdom', evidently implies that this feast took place on the occasion of the king's accession to the throne, and immediately the author states that it occurred ' in the third year of his reign'. Hence it is obvious that the former clause can have no other meaning than "when the king Ahasuerus was firmly established on the throne of his kingdom'." Both the Alexandrian translator and Rashi felt this difficulty; the former therefore renders this clause ö $\tau \epsilon$

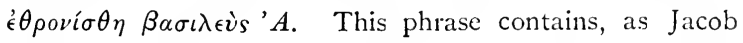
points out, the special Egyptian term for the coronation festivities of the Ptolemies. ${ }^{6}$ Rashi explains this clause "when the kingdom was established, in his hand'. Both interpretations may mean the same. The author evidently intends to inform us that the king

4 See Ed. Heyer, Geschichte, III, p. 4 I6.

${ }^{5}$ Paton, l.c., p. 124, cbserves: 'The language suggests the beginning of his reign, but I. 3 says that it was in the third year'. H. Winckler (Der Alte Oricut und die Geschichtsforschung, 1906, p. 2 I) thinks that this phrase means: 'when he ascended the throne'. H. Willrich, l. c., p. I5, sees in this expression an official coronation that may have been celebrated three years after the accession of the king. But cf. Keil, l.c., p. 6r7, and Bertheau-Ryssel, l.c., p. 384 .

${ }^{6}$ See Jacob, l.c., p. $28 \mathrm{r}$. 
of our story did not feel himself secure in the possession of his throne at the beginning of his reign. He must have had a rival who challenged his right to the throne. Therefore no festivities took place on his accession. But in the third year of his reign, after having defeated his rival, and being now generally recognized as legitimate ruler and thus firmly established on his throne, the king celebrated the event in the manner described. This was actually a coronation feast. If this interpretation is true, the ling cannot be identified with Xerxes. The latter being the son of Darius and Atossa, the daughter of Cyrus the Great, his right to the throne, after his accession, was not contested-though during his father's lifetime there might have arisen a cloubt whether Xerxes, who was born in the purple, or his elder brother should succeed to the throne. There is no record that ferxes had to assert his right to the succession against any claimant. None of his brothers rebelled against him.

(4) The events narrated in the second chapter of Esther could hardly have occurred between the third and seventh years of Xerxes' reign. He was at that time fully occupied with his preparations for the war against Greece. The advice of the courtiers seems to have been carried out in the sixth year. But Xerxes was at that time in Greece. The selection of Esther took place in the seventh year. But the testing of the other virgins. before Esther's turn came, must have lasted several months. We would have to assume that Xerxes at that time was already back from Sardis. Such an assumption is not impossible, but rather improbable.

(5) Esther could not have been the queen of Nerxes 7 See Herodotus VII. 23.

H. 
between the serenth and twelfth years of his reign, as the queen at that time was Amestris, and she cannot be identified with Esther. ${ }^{8}$ We cannot accept Jampel's forced suggestion that Esther was not a real queen, but one of Xerxes' wives-not a concubine ${ }^{9}$-as she is continually referred to as queen in our story. Moreover, according to a statement of Herodotus, Darius made an agreement with the six conspirators against Pseudo-Smerdis, stipulating that the king was to marry into no families except those of the conspirators. ${ }^{10}$ If this statement be true, it is very improbable that this agreement was disregarded by the immediate successor of Darius. But history shows that kings hardly ever faithfully observe agreements made by distant ancestors with their subjects, and we may well imagine that this agreement was violated in a later period. Furthermore, if we may believe Herodotus, the Persian kings had a very convenient ancient law that decreed 'that the king of Persia might do whatever he pleased ',"1 which enabled them to set aside any law or agreement that interfered with their own pleasure.

Esther 3.6. (6) The passage 'The Jews throughout the whole kingdom of Ahasuerus'. and similar expressions, apparently imply that at the period of our story there were Jews outside of the Persian empire. Herodotus does not know anything about the Jews. ${ }^{12}$ This fact alone is sufficient

8 Amestris was the daughter of Otanes cf. Herodotus IX, I09; Ctesias, Persica 20. Cf. Paton, l. c., p. 7 r f.

9 Jampel, l. c., p. II $4 . \quad{ }^{10}$ Herodotus III, $84 . \quad{ }^{11}$ Ibid. III, 3 I.

12 Ed. Meyer Geschichte, III, p. 218) is evidently wrong in identifying

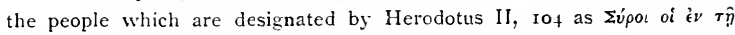

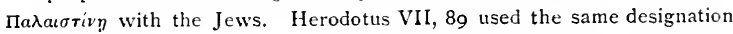
for the Syrians who, along with the Phoenicians, furnished three hundred ressels for the war against Greece. This of course can refer only to those 
evidence that no Jew's lived at that time among the Greeks. Egypt was under the dominion of Persia during the reign of Xerres. An assumption that Jews lived among the independent, savage Scythians is not to be considered. The only independent, cirilized country where Jews might have settled was Carthage, and so far we have no record of the existence of Jews among the Carthaginians. Hence it is highly improbable that Jews existed outside of the Persian empire at the time of Xerxes.

(7) The passage 'There is a certain people scattered Esther 3.8. and dispersed among the people in all the provinces of thy kingdom' distinctly shows that the Jews at the period of our story had already settled in all parts of the Persian empire. If those events occurred under the reign of Xerxes, it is hardly credible that such a dispersion should have been accomplished in the relatively short space of about sixty years. However, this objection is not conclusive. ${ }^{13}$

(8) The main proof, however, that Ahasuerus cannot be identified with Xerxes, may be seen in the principal event of our story. If we are to believe that a Persian king had once decreed the destruction of the Jews, we must advance some plausible reason for such an action. Considering it from the point of view of all commentators, we encounter a monstrosity inconceirable to the human mind. Does it stand to reason that Haman, on account of a single individual, who had refused to pay him due homage, should have resolved to destroy a whole innocent race? Now

Syrians who inhabited the sea coast, and the Jews in the Persian period were not inhabitants of the sea-coast.

13 This problem is treated in the Appendix. The Exiles of Judah and Israel'. 
it is true the bloody pages of Jewish history bear testimony to terrible persecutions of the Jews, in all ages, down to the present, through no fault of their own. But we must bear in mind that this hostile attitude was always caused by religious fanaticism and intolerance. In post-exilic times, the hatred against the Jews was never directed against the Jewish race, but against the Jewish religion. The Jew who became a pagan, or embraced Christianity or Islam, was in all countries and in all ages just as safe as one of the other races. It was always the aim of intolerant rulers to compel the Jews to abandon their exclusive position, and this task could not be accomplished except by means of persecution. We know that the Jews who abandoned their religion could attain to the highest dignity in the Christian hierarchy, even in the Dark Ages. But Haman's action is without a parallel in history. If he had been a religious fanatic, he would have compelled the Jews to abandon their religion, as did Antiochus Epiphanes.

However, let us admit that Haman was of an exceptional turn of mind, and desired to exterminate the whole Jewish race on account of Mordecai. But how can we believe that Xerxes was exactly of the same turn of mind and readily agreed to carry out his intentions? Jampel's suggestion that Xerxes was afraid of the Scythians, who frequently laid waste the country: and therefore believed that Haman's accusation referred to them,${ }^{14}$ is impossible. Who ever heard of enemies of this kind being destroyed by royal decrees? Xerxes might just as well have decreed the destruction of Greece! If the Scythian hordes had been so weak as to be destroyed by the people, they could 
not have inspired any fear. There was no need to ask special permission and offer a large amount of money for the destruction of enemies of this kind. If he had been afraid of these hordes, Xerxes would gladly have given anything to rid himself of them. Moreover, the words of Haman, 'scattered and dispersed in all the provinces of thy kingdom', distinctly indicate that he could not have referred to the Scythians, who were by no means scattered and dispersed in all the provinces, but came in large bodies from their steppes whenever they committed their depredations. It is also preposterous to assume that Xerxes could have decreed the extermination of a people without knowing their name. The testimony of classical authors, quoted by Jampel, that Xerxes was of very inferior intelligence, 'being a body without a soul', does not deserve any credence. The only authority for the personality of Xerxes is the honest, unbiased Herodotuswho, though he may in some cases have been misinformed, never distorted the truth. The profound remarks which Herodotus ascribes to Xerxes, no matter whether they are oratorical embellishments or not, indicate that he considered this king a man of intelligence. It is wrong to see in the scourging of the Hellespont a childish action, as is generally done by the commentators. Herodotus and the Greeks did not look upon it as childish, but as impious. It was a symbolic action, a chastisement of the Greek god Poseidon, whom Xerxes may have held to be a creature of Ahriman, according to his religious conception. This action was in some respect similar to the striking of the Red Sea and of the Rock by Moses. According to Herodotus, Cyrus punished the river Gyndes by dividing it into three hundred and sixty parts for a lesser cause, his 
favourite horse having been drowned in it. ${ }^{15}$ Xerxes was not inferior in intelligence to any of his successors. Curtius justly describes him as having had a deep sense of the dignity of the empire. ${ }^{16}$ The Persians in later times may have depicted him as an incapable ruler, attributing to his incapacity the disgraceful defeats Persia suffered under his reign. But exegetes have no right to stamp Xerxes a fool for the purpose of confirming the veracity of the Book of Esther.

It has further been suggested by Jampel ${ }^{17}$ that Xerxes' detestation of the Jews may have been caused by his religious fanaticism. Now there is no doubt that Xerxes was a fanatical adherent of the Zoroastrian religion, apparently more so than his father Darius. The former even removed the statue of Bel-Marduk from the Babylonian temple, an action which his father 'had not the hardihood to do', as Herodotus informs us. ${ }^{1 \text { s }}$ It has been pointed out that Xerxes after the fourth year of his reign is no longer styled 'king of Babylon' in the Babylonian documents; for this title could only be borne by a king who seized the hand of Bel-Marduk on the New Year festival. ${ }^{1}$ Though the action of Xerxes may have been a political measure and done for the purpose of abolishing the kingdom of Babylonia and uniting it with the Persian empire, and not with any religious motives, nevertheless Xerres could

15 Herodotus 1, 189. Grote. in his History of Grece, IV, p. 284. does not doubt this narrative, though it has been said that $\mathrm{Cy}$ rus's real intention was to put this river cut of his way in case he should find it necessary to cross it.

16 In his History of Grece, 11, p. 273 .

17 l.c., p. I19. $\quad 18$ Herodotus I, 183.

19 Cf. Ed. Mejer, Forschungtn zur Altcn Gischichte. Halle, 1892. I, p. 47 , and Geochichte. I11, p. 130. 
hardly have committed such a sacrilegious decd, if he had not been, as a true Zoroastrian, an inveterate enemy of the worship of idols. It has even been asserted that he destroyed Greek temples for the same reason. ${ }^{20}$ This, however, is rather doubtful, as Herodotus states that on the day after the temple of Minerva was set on fire, Xerres assembled all the Athenian exiles and bade them go into the temple and offer sacrifices after their own fashion. ${ }^{21}$ Xerxes would in all probability have destroyed the temples of his enemies, even if he had been an idolater. But the very fact that Xerxes was an ardent Zoroastrian is proof to the contrary, that he could not have been hostile to the Jews on account of their religion. We shall see that the latter were by no means averse to the Persian religion, as long as it remained in its purity, free from idolatrous representations. Both the Jewish and Zoroastrian religion were in the main points, superficially at least, alike, acknowledging only one God and having no idols. ${ }^{22}$ If Xerxes was an ardent Zoroastrian, he must have been favourably inclined towards the only non-Iranian subjects in his empire, who had a religion akin to that of the Persians, and readily acknowledged the divinity of Ahuramazda. As significant for his favourable attitude towards the Jews we consider

20 Cf. G. Rawlinson's Herodotus, vol. III. p. 254 ; IV, p. 241, and Cassel, l.c., p. 82.

21 Herodotus VIII, 54. The fact that Xerxes destroyed Greek temples is no proof that he was opposed to the worship of idois. Herodotus VIII, 35 states that he intended to invade Delphos for the purpose of seizing the riches which were laid up there. It was a political measure lest the Greeks might use these treasures against him. For the same purpose he may have plundered the very rich temple of Apollo at Aboe, according to Herodotus VIII, 33. Ed. Heyer (Geschichte, III, p. 255) contends that Xerxes was not hostile towards the Greek gods.

22 See Chapter V. 
the statement of Ezra, 'And in the days of Ahasuerus, in the beginning of his reign, they wrote an accusation against the inhabitants of Judea and Jerusalem.' ${ }^{23}$ It is noteworthy that nothing is said about the result of this accusation." ${ }^{24}$ It is evidently due to Xerxes' benevolent attitude towards the Jews that this accusation remained without result. Seeing that we cannot assign sufficient reasons for the danger of extermination impending over the Jews under the reign of Xerxes, it is obvious that the latter cannot be identified with the king of our story.

Esther IO. 1 .

(9) There is a remarkable statement in the last chapter of our story" 'And the king Ahasuerus laid a tribute upon the land, and upon the isles of the sea' ${ }^{-5}$ This passage has puzzled all commentators: What connexion may this trivial remark have with the preceding events? Cassel's ingenious cxplanation, that the king indemnified himself for the ten thousand talents he had lost in frustrating Haman's decree, ${ }^{26}$ is impossible. The money that Haman promised was not a profit, but indemnification for the loss of Jewish taxes. Further, the king had renounced all

23 Ezra 4. 6. Ahasuerus in this passage is undoubtedly Xerxes, not Cambyses. Cf. Keil, p. 442, and Bertheau-Ryssel, p. 64 .

${ }_{24}$ Marquart. l. c., p. 63. sees in this passage the gloss of an interpolator. But if the intention of the alleged interpolator was to give us some information about troubles of the Judeans under the reign of Xerxes, why does he stop with the accusation? This 'interpolator' was apparently a better historian than the author of the Book of Daniel, since he placed Ahasuerus between Darius I and Artaxerxes I. Siegfried, in his commentary on Ezra, p. 24, observes: 'The petition to Ahasuerus is missing.... But this gap is filled out by Ezra 2. 17-25'. But Ezra omits this passage altogether, and the rerses $17-25$ correspond. with the exception of the proper names, to the Hebrew text.

25 See Keil, p. 658; Bertheau-Ryssel. p. 545; Wildeboer, p. 196; Siegfried, p. I75: Paton, p. 303, \&c.

2r Cassel. l. r.. p. 236. 
claim to this money, in saying: "The silver is given to thee'. Finally, the king had already indemnified himself by confiscating Haman's property. ${ }^{2 i}$ The author evidently intended to inform the reader about the great statesmanship of Mordecai, that the king by following his counsel was very fortunate in his enterprises, and increased his dominions by acquiring a new land and isles on which he levied tribute. $^{23}$ But we know that Xerxes did not increase hiempire; on the contrary, he lost the Greek cities and islands of Asia Minor, the whoie of Thrace. and the greatcr part of Cyprus between the years $479-476$ B.C.L., and never recovered them. Hence such a statement cannot refer to the reign of Xerxes.

${ }_{27}$ Though Ahasuerus made a present of it to Esther, the property of his wife was always at his disposal.

2s Ibn Ezra, ad locum, is the only commentator whe recognized the meaning of this passage. 


\section{CHAPTER IV}

Ahasuerus' identity with Artaxerxes II, Mnemon-Plutarch's Life of Artaxerxes-Plutarch's sources and their reliability-Artaxerxes' characterHis relations to the Greeks - The Peace of Antalcidas-The rebellion of Cyrus the Younger-The date of the battle of Cunaxa-Artaxerxes' celebration of his victory-His domestic life-Quarrels between his queen and his mother-The rule of the harem-The queen's disobedience-Her degradation and murder-Her name-Artaxerxes' concubines-Artaxerxes' suspicions against his grandees-His palace at Susa-The name Ahasuerus in the Hebrew version-A comparison between Xerxes and Artaxerxes IIThe resurrection of the Persian empire-The Arsacides alleged descendants of Artaxerxes II-His proper name-The uniformity of the ScripturesThe name Artaxerxes in the Greek version.

THE veracity of a story has to be judged by the facts narrated therein, and these facts on their own merits, independently of the names of the dramatis personae, which may have been changed for some reason. The modern exegetes of the Book of Esther evidently do not grant these premisses. Having identified Ahasuerus with Xerxes, an identification that etymologically cannot be doubted, and finding that historically the events of this Book could not have occurred under the reign of the latter, they conclude that the story is fictitious. This conclusion is erroneous. We readily concede that an assumption that these events actually happened under Xerxes' reign is beyond the limits of consideration, as we have shown in the preceding chapter. But this fact does not prove that these events are unhistorical. They might have occurred under a ruler whose name was not Ahasuerus. We indeed 
contend that the events of our story, being corroborated by cxternal, non-biblical historical sources, camnot be denied, and that the name of the king found in the present Hebrew version of the Book of Esther is fictitious. In the course of our investigation, we hope to prove the truth of our contention.

Historical events under the reign of Artaxerxes II Mnemon (404/3-359/8 B.C.E.) leave no room for doubt that the events narrated in our story occurred under that king's reign. The latter having played a part in the history of Greece, such as no other Persian king before or after him, we have abundant information about his political affairs, which can be traced in our story. But records about his domestic life, written by various Greek authors, are scanty and not of a character to be implicitly relied upon, being apparently a mixture of truth and fiction. The writings of the older classical historians who dealt with this subject, like Ctesias of Cnidus, Deinon of Colophon, Heraclides of Cyme, and others are lost, with the exception of some fragments of Ctesias. ${ }^{1}$ All later historians who touched upon this subject drew from these sources. Plutarch, in his Life of Artaxerxes, relied for the description of the first part of this ling's reign chiefly upon Ctesias, for that of the later years chiefly upon Deinon, but drew also from Heraclides and other sources. Ctesias could testify as an eye-witness to the events that happoned in the first six years of Artaxcrxes' reign, since he was physician at the Persian court for about seventeen years (414-398). Hc wrote his history about 390. His testimony ought secmingly to be regarded of prominent value.

1 For the historical sources for this period see Ed. Meyer Gesch. III. Pp. $7 \mathrm{ff}$ 
But Plutarch does not place much confidence in him, charging that he had filled his books with a number of extravagant and incredible fables. Ctesias had indeed in antiquity the not undeserved reputation of a liar and forger. Deinon wrote his history towards the end of the Achaemenian period, and is generally regarded as trustworthy. For our present investigation, we must chiefly rely upon Plutarch. But judging by his Artaxerxes, we must doubt Deinon's reliabiiity. We shall demonstrate by a few striking examples that this historian does not deserve great confidence. It is surprising to see our modern historians, like Ferdinand $\mathrm{Justi}^{2}$ and even Eduard Meyer, the greatest authority on ancient history in our times, implicitly accepting in their Histories many statements of Plutarch, without subjecting them to a critical analysis. Ve call attention to the following points :

(I) According to Plutarch, Artaxerxes II reached the age of ninety-four years. ${ }^{3}$ Both $\mathrm{Justi}^{4}$ and Eduard Meyer ${ }^{5}$ accept this statement. If this be true, Artaxerxes must have been forty-eight at the time of his accession to the throne, since he reigned from $404 / 3$ to $359 / 8$. But the latter was the son of Darius II and Parysatis. They had, according to Plutarch, ${ }^{6}$ four children, of whom Artaxerxes was the eldest, Cyrus the second, and Ostanes and Oxatres the two youngest. Darius reigned 424-404. As Cyrus claimed the throne on account of having been born in the purple, he must have been about nineteen years old at the

${ }^{2}$ Geschichie des Alten Persicns, Berlin, 1879 (in Oncken's 'Allgemeine Geschichte', part IV.

Plutarch's Artaxeres, XXx, 9.

4 In his Geschichte, p. I 36.

${ }^{5}$ In his Forschungen, p. 480 . In his Geschichte he says that Artaxerxes was wralt.

6. Artarcress, I, 2. 
demise of his father. Accordingly Artaxerxes would have been twenty-nine years older than his second brother. Parysatis, remarkable for her cruelty, would have been more remarkable as a natural phenomenon, having borne three lusty sons after an intermission of twenty-nine years. ${ }^{7}$ As a matter of fact, Artaxerxes was merely a few. years older than his second brother. He must have been at the prime of his life at the time of his campaign against the Cadusians, about twenty-four years after his accession. if he could bear all the hardships of the march like the meanest soldier and show strength and alacrity by marching two hundred furlongs daily, as Plutarch informs us. ${ }^{3}$ However, Plutarch is in this case not as much to blame as the modern historians; for the former gives Artaxerxes a reign of sixty-two years, ${ }^{9}$ and thus Cyrus would have been only about thirteen years younger than his eldest brother. If historians rightly reject the statement concerning the years of his reign as unhistorical, they ought to have repudiated also that as to Artaxerxes' age!

(2) Plutarch's date of Artaxerxes' reign, mentioned above, is not a scribal error, as the same date is given by Sulpicius Severus, and both drew from the same source. from Deinon, according to Ed. Meyer. ${ }^{10}$ The latter

7 There is also another chronological improbability. Artaxerxes I, who was the younger son of Xerxes, was undoubtedly born in the purple. As the latter ascended the throne ${ }_{4} 8_{4}$, and was murdered ${ }_{4} 65$, Artaxerxes could hardly have been more than eighteen at the time of his accession. Now if Artaxerxes II was forty.eight years old when he became king, he must have been born 452. Then Artaxerxes I would have become a grandfather at the age of thirty. G. Rawlinson (Herod. IV, p. 2) considers it incredible that Xerxes should have had a grown-up son when he was at most thirty-six years old.

* Artaxiries, XXIV, 1 i.

Ibid. $\mathrm{x} \times \mathrm{X}, 9$.

10 Forschungen, p. 489 . 
admits that he is unable to explain how such an error could have occurred. He evidently overlooked the fact that this date, giving Artaxerses the age of ninety-four years at his death. is the basis of all the stories about Cyrus and Parysatis, told by Plutarch. It is also possible to explain the occurrence of this error: Eusebius gives Artaxerxes II a reign of forty years, while Africanus gives Artaxerxes III a reign of twenty-two years. Hence it is very possible that the date given by Plutarch and Severus include the regnal years of both these kings. This date sufficiently shows how badly Deinon must have been informed about the Persian history of this period.

(3) Plutarch tells us that Cyrus had a concubine named Aspasia, who had been taken prisoner in the battle of Cunaxa, and afterwards became the concubine of Artaxerxes. But his oldest son Darius, after having been appointed successor, requested his father to give Aspasia to him. Artaxerxes complied with his request, but soon afterwards he took her away and made her priestess of Diana of Ecbatana, whom they called Anaitis, that she might pass the remainder of her life in chastity. ${ }^{11}$ Darius, incensed and persuaded by Teribazus, conspired against the life of his father and intended to assassinate him in his bedchamber. ${ }^{12}$ When these events occurred, Artaxerxes was

11 Artaxerves, XXvil, 4.

12 Ibid. XXIX. Plutarch may congratulate himself that he was not a Jewish author. The commentators on Esther concern themselves with the difficult question how Esther, who as cousin of Mordecai must have been at least fifty or sixty years of age, should have been so beautiful as to captivate the heart of Xerxes. Plutarch's tale is more incredible, and nevertheless Justi, Gesch., p. I37, accepts it literally, without expressing any doubt as to its historicity. Some commentators believe that in the seclusion and care of an Oriental harem beauty lasts to an extreme age (see Bertheau-Ryssel, p. 400, and Paton, p. 170). However, just the 
already far adranced in years, as Plutarch asserts. The fact that a successor to the throne was appointed show's that they happened in the last years of his reign. At that time Aspasia was already an old woman, at the age of seventy at least, according to Plutarch's chronology. Accordingly, 'the goddess of beauty' could not have 'cuntributed her share towards persuading Darius by putting him in mind of the loss of Aspasia'.

(4) Plutarch further tells us that Parysatis was instrumental in bringing about the marriage of Artaxerxes to his own daughter Atossa, by telling him to make her his wife, without regarding the laws and opinions of the Greeks. ${ }^{13}$ This daughter was apparently rather young at the time of her marriage to her own father, since her brother Ochus, the youngest son of Artaxerxes, is said to have promised her to make her his queen, in case she would assist him in putting his elder brothers out of the ray. ${ }^{14}$ This occurred at the time of Darius's conspiracy. But according to Plutarch, Parysatis must have been fifty years of age at least. when Artaxerxes ascended the throne, and could hardly have been alive towards the end of his reign.

Historians attach too much importance to Persian harem-stories recorded by Greek authors. We ought to bear in mind that the Persian harem was more closely guarded than the Golden Fleece. No outsider could know

contrary is true. Justi, l.c., p. I25, observes: The charms of the women last seldom more than eight or nine years. The splendid beauty soon turns withered, lean, blear-eyed, and becomes in every respect an ugly woman. Each year brings a new wrinkle, until the former light of the harem is quite obscured'. From this point of view, we understand why there were new gatherings of virgins from time to time.

15 Artaxerars, XXili, 5.

1" Ibid. XXVI, 3. 
exactly the real happenings there. ${ }^{1 ;}$ The stories are based upon rumours which may have been embellished and distorted, not upon first-hand information. It should also be taken into account that the Greek writers in telling startling stories about the barbarians, were playing to the gallery. The Greek physicians at the Persian court were most likely better informed about happenings in the harem. But with the exception of Ctesias, who is fond of giving fiction instead of truth, especially where his own ambition was concerned, these physicians did not write histories.

There is no doubt some truth in many stories of Plutarch's Artaxerxes, but it is mixed with fiction. There may have been a conspiracy against the life of Artaxerxes in the first years of his reign, in which Aspasia played some part. Who knows whether she was not involved in some conspiracy to avenge the death of her lover Cyrus, which the Greek author mixed up with the conspiracy of Darius that occurred about forty years later? Ed. Meyer, who in his History gave full credence to Plutarch's account. seems to have lost faith in it, as his description of the events under discussion, in the Encyclop. Brit. (I I th Edition), differs in several points from that of Plutarch. He writes: 'In the last years of his reign, he had sunk into a perfect dotage. All his time was spent in the harem, the intrigues of which were complicated by marrying his own daughter Atossa. At the same time his sons were quarrelling about his succession. One of them. Ochus, induced his father to condemn to death three of his elder brothers who stood in his way. Shortly afterwards Artaxerxes died.' This

15 It is different with Jewish writers, as some of them were in all probability eunuchs 'see Chapter VII', and therefore were better acquainted with the secrets of the harem than the average Persians. 
historian evidently does not believe in Plutarch's stories, that Darius was found guilty of a conspiracy, that the second brother, Ariaspes, committed suicide, and that the third brother was murdered by Harpates at the order of Ochus. ${ }^{16}$ We must indeed take these stories with a grain of salt, not as did Justi who in his History'adheres faithfully to Plutarch's description in all its details.

It is noteworthy that there is a period of about thirty years at least between the death of the first queen of Artaxerxes and the alleged marriage to his own daughter Atossa. Who was queen in the meantime? If there had been a queen, she would in all probability have taken part in the intrigues at the court, as did all the Persian queens, and Greek writers would have told us something about her. There seems to have been a queen who differed from all her predecessors, in not mixing herself in the intrigues of the court, and, therefore, Greek writers did not know anything about her. Now it is true, Plutarch states: 'Some historians, amongst whom? is :Heraclides of Cyme, affirm that Artaxerxes married not only Atossa, but also another of his daughters Amestris.' ${ }^{17}$ However, the latter marriage could only have preceded that to Atossa by a few years; for Plutarch tells us that Amestris had been promised to Teribazus, but Artaxerxes, instead of keeping his promise, married her himself, promising Teribazus that he should have his youngest daughter Atossa, of whom, however, he also became enamoured and whom he married. ${ }^{13}$ Moreover, Plutarch's statement that Artaxerxes married his own daughters, though generally accepted by all historians,

18 Ibid XXVII, 7-9.

H. 
is rather doubtful. ${ }^{19}$ We have no similar record of any other Persian king of the Achaemenians, Arsacids and Sassanids. Artaxerxes may have had a queen whose name by some was said to be Atossa, by others, Amestris. But the Greek writers, knowing that the Zoroastrian religion considers next-of-kin marriage sacrosanct, and being led astray by the queen's names, identical with those of his daughters, believed that he married the latter. ${ }^{20}$

Ed. Meyer describes Artaxerxes II as being a goodnatured monarch, but weak, capricious, readily accessible to personal influences and dependent upon his favourites; in his time the baleful influence of the harem made appalling progress.' ${ }^{21}$ The character of Ahasuerus, as represented in the Book of Esther, could not be more accurately depicted than by this description. However, notwithstanding his character, Artaxerxes II was, without exception, the greatest monarch of the Achaemenian dynasty. It is true he does not deserve any credit for his power. His greatness was due neither to his own personality nor to the strength of the Persian empire, which on the contrary showed in all parts under his reign

13 Cf., however. Ed. Meyer, Gesch., Einleitung, 1910, pp. 23-32, and III, p. 4I. He accepts this statement on Plutarch's authority. The latter tells us in connexion with Artaxerxes' marriage to his own daughter: 'his affection for Atossa was so strong, that though she had a leprosy which spread itself over her body, he was not disgusted at it'. This statement is not in accord with that of Herodotus. I, I39, who writes: - If a Persian has the leprosy, he is not allowed to enter into a city or to have any dealings with the other Persians.'

20 It is rather curious that the names of Artaxerxes' queen Hadassah and Esther should be almost identical with those of his two daughters, Atossa and Amestris, he is said to have married.

21 See his article 'Artaxerxes', in the Encyclop. Brit., Irth ed., and Geschichte, V, p. I8I. 
visible signs of decline and decay, but to the discord and corruption of the Greeks. Still the Persians must have looked upon him with the greatest admiration for having vindicated their honour. Since the days of Marathon and the humiliating defeats at Salamis, Plataea, and Mycale, the Persians, this proud nation which considered itself to be greatly superior in all respects to the rest of mankind, ${ }^{22}$ could not help admitting the superiority of the Greeks, by whom they had been disgracefully defeated. Ed. Meyer observes: 'In many Persians may have been alive the feeling of disgrace that the great campaign had ended so deplorably, that they were even unable to come to the assistance of the brave garrisons in Thrace.' ${ }^{23}$ Both Artaxerxes I, who was compelled to recognize the independence of the Greeks of Asia Minor, and Darius II were only too glad when the Greeks did not interfere in their own dominion. ${ }^{24}$ But under the rule of Artaxerxes II, the Persians could lift up their heads again and look down with contempt upon their former arch-enemies, the Greeks. What a spectacle it must have been for the Persians to see the descendants of the heroes of many glorious battles crouching at the feet of their king and paying him divine honours! ${ }^{25}$ The aim for which Darius I and his successor Xerxes had striven in vain, the subjection of the Greeks, was actually attained by Artaxerxes II. Greece was subdued, and officially recognized Persia's suzerainty. There is no doubt that this king's memory was held by the Persians in the greatest esteem and reverence even in

22 Herodotus I, I34.

23 Geschichte, III, p. $5^{85}$.

24 Egypt would never have succeeded in freeing itself from Persia without the aid of the Greeks.

25 Artaxerxes, XXII, 8. 
later times. Diodorus Siculus informs us why Ochus, the successor of Artaxerxes II, assumed the name Artaxerxes: 'Artaxerxes, ruling the kingdom with great justice and integrity, and being a great lover and earnest promoter of peace, the Persians decreed that all succeeding kings should be called by his name.' ${ }^{26}$ Such an unhistorical and ridiculous legend must have come from an oriental source at a time when Persian history was no longer known, but the memory of Artaxerxes II was still alive. We consider it hardly a coincidence that the founder of the Neo-Persian empire bore the name of Artaxeres (Ardashir, Artashatr). ${ }^{27}$

Artaxerxes II was, like Darius I, incontestably king of Asia. The extent of his empire is defined in the Book Esther of Esther by the geographical term: "from India unto I. I; 8.9 Ethiopia' (טהודו ועד כו"). ${ }^{28}$ At the outset of his reign, he was fortunate in recovering many Greek cities of Asia Ninor lost about eighty years before his reign by his great-grandfather Xerxes. The fall of Athens (402 B.C.E.) ended its hegemony over these cities, and they became an easy prey to the Persian empire. Sparta's plan to continue Athen's policy and to establish a new hegemony, was frustrated by the corruption of Greece. Plutarch states that Artaxerxes forced Agesilaus, who was victorious everywhere, to leave Asia Minor by sending Hermocrates into Greece with a great amount of gold, and instructed him to corrupt with it the leading men in the Greek states and to stir up a Grecian war against Sparta. The most important

26 In his Historical Library, XV, 2.

27 See Justi, Geschichte, p. 177 .

${ }_{28}$ There may be some doubt whether such a geographical term includes Egypt. The latter country was no longer under the Persian rule at the period of our story. But we may reasonably assume that its independence was never recognized by the Persian kings (cf. Chapter I, n. 5). 
cities formed a league against it. Artaxerxes deprived Sparta also of the dominion of the sea through the agency of the Athenian Conon who acted in conjunction with the Persian satrap Pharnabazus. After he had won the battle of Cnidus, he drew almost the whole of Greece into his interest. The Peace of Antalcidas (387 B.C.E.) was entirely of his own making. Sparta, at the advice of Antalcidas, gave up to the Persian king 'all the Greck citics of Asia Minor, and the islands which are reckoned anong its dependencies, to be held as tributaries', as stipulated by this Peace. ${ }^{29}$ It is noteworthy that both Plutarch and the author of the Book of Esther, in describing the signal success of Artaxerxes II, use exactly the same expression. The passage: 'And the king Ahasuerus laid a tribute on the land and the isles of the sea ', undoubtedly refers to the Greek part of Asia Minor and the islands which became tributary to this king, by virtue of the Peace of Antalcidas. It was concluded five years after the events narrated in our story. Our author does not say that Ahasuerus came into the possession of these territories by means of conquest. He was an historian, and knew that they were not acquired by force of arms but by diplomacy. Being well acquainted with the historical events of that period, he was justified in saying: 'And all the acts of his power and of his might ... are they not written in the book of Esther to. 2 . the chronicles of the kings of Media and Persia?' These high terms of praise were well merited, and justly applied to the political achievements of this king. Artaxerxes II was indeed, from the Persian point of view, as Diodorus said, an earnest promoter and great lover of peace. By his famous 'Royal l'eace', he freed his empire from its 
hereditary enemies, gained valuable possessions, and deprived Greece of its independence, so that the Greeks themselves had hardly anything left worth fighting for. But from a Greek point of view the Greek was right who exclaimed: 'Alas for Greece, when the Lacedaemonians are turning Persians!' 30

Darius II died in the spring of 404 B.C.E. He had appointed his eldest son Artaxerxes as his successor. This appointment was not in accord with the precedent of Darius I, who had appointed his younger son Xerxes as his successor, because he was born in the purple. According to this precedent, Cyrus, the second son of Darius II, had a better claim to the throne, having been born after the latter had become king. ${ }^{31}$ It was also well known that Parysatis, the all-powerful queen, the mother of both Artaxerxes and Cyrus, was strongly in favour of her younger son. Hence Artaxerxes II, at the beginning of his reign, did not feel himself secure in the possession of the throne. He may have well remembered how Xerxes II, after a reign of forty-five days, had been murdered by his brother Sogdianus, and the latter in his turn, after several months, at the order of his own father Darius II. Thus fratricide was not unusual among the members of his dynasty. Cyrus, indeed, at the accession of his brother, on the occasion of his consecration at Pasargadae, designed to murder him. This design was frustrated by Tissaphernes. The tears and entreaties of his mother prevailed with Artaxerxes to pardon his brother for this crime, and he sent him back to Lydia. ${ }^{32}$ Soon after, despising his brother for his weakness for having let such a dangerous enemy escape, Cyrus again began to conspire against

3o Ibid. XXII, 4.

s1 Ibid. II, 4-5.

32 Ibid. III. 
him. Artaxerxes was well aware of his designs, being warned of all his movements by Tissaphernes. But Parysatis made it her business to remove the king's suspicions.:3 Meanwhile Cyrus gathered a large army, and also wrote to the Lacedaemonians for assistance, making them great promises in case he should achieve his aim. In this letter he spoke in very high terms of himself, telling them that he had a greater and more princely heart than his brother; that he was the better philosopher, being instructed in the doctrines of the Magi, ${ }^{34}$ and that he could drink more wine and carry it better (oivo $\pi i \nu \in \iota \nu$

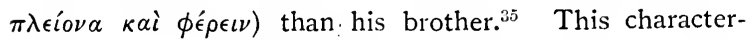
ization of Artaxerxes II by his brother Cyrus is of the highest importance for the interpretation of the Book of Esther. Artaxerxes was indeed a weak character. He was not a good Zoroastrian, for under his reign the Zoroastrian religion was completely corrupted. ${ }^{30}$ Finally, under the influence of wine, he was losing his senses. ${ }^{37}$

Having made all preparations for carrying out his designs, Cyrus began his march against the king with a numerous army, among which were about thirteen thousand Greek mercenaries. $\mathrm{He}$ found one pretence after another for having such an armament on foot; but his real designs did not remain long undiscovered. For Tissaphernes went in person to inform the king of them. ${ }^{38}$ Therefore on the march Cyrus openly declared his intentions to overthrow his brother and to seize the crown.

33 Artaxerxes, IV, 3.

34 Cyrus evidently meant to imply to the Greeks that the Magi would willingly assist him in his enterprise.
35 Artaxerxes, VI, 3-4.
3i See Chapter VI.
37 See Chapter VIII.
s* Ataverxes, VI, 6. 
This rebellion came to an end at the battle of Cunaxa in which his army was defeated and Cyrus lost his life. This battle occurred in October 404. Now it is well known that the Babylonian chronology is a year behind that of the Greeks and Egyptians. The latter had the system of ante-dating, that is to say, the year in which a king died is reckoned as the first year of the succeeding king, and with the civil New Year begins the second year of his reign. Accordingly Artaxerxes II, having ascended the throne in the year $40_{4}$, the Greek chronology places the battle of Cunaxa in the fourth year of his reign. The Babylonians, however, had the system of post-dating, the year in which a king ascends the throne is given to his predecessor, while the first year of his own reign begins with the first of Nisan, on the New Year festival, in which the king had to seize the hand of Bël-Marduk, in order to be recognized as legitimate king. ${ }^{39}$ The Book of Esther was undoubtedly written in Babylonia, and according to Babylonian chronology, the year 404 in which Artaxerxes ascended the throne was reckoned to his predecessor Darius II, and his own reign began 403. Therefore the battle of Cunaxa occurred two years and a half after his accession to the throne.

Esther Cyrus being dead, Artaxerxes II was at length firmly I. 2-9. established on his throne. He could now in perfect security celebrate the long delayed coronation festivities, and at the same time the victory over his enemy. It was done in a magnificent fashion, befitting the rank of the Great King, and the signal occasion; he had saved his life and his throne. The description of these festivitics is therefore by no means exaggerated, as all modern commentators ${ }^{39}$ Cf. Ed. Meyer, Forschungen, pp. 437-502. 
contend. ${ }^{40}$ This celebration lasted throughout the whole Winter; one hundred and eighty days. The battle of Cunaxa occurred, as we have seen, in October, and the festivities lasted from October to April. ${ }^{41}$ Satraps and governors, grandees and nobles, from all parts of the empire, not a few from a great distance, arrived daily and departed after a sojourn of a few days. Many who formerly favoured the claim of Cyrus may have hastene:d to the court to assert their loyalty to the victorious king. Plutarch states: "There were turbulent and factious men who represented that the affairs of Persia required a king of such a magnificent spirit, so able a warrior, and so generous a master as Cyrus was; and that the dignity of so great an empire could not be supported without a prince of high thoughts and noble ambition. ${ }^{42}$ All these guests had to be magnificently entertained. Besides these officials and nobles, the king feasted 'the army of Persia and Media' (חיל פרס ומדי), ${ }^{43}$ that is to say, those loyal warriors who came to his assistance against his brother. It must have been a very large army, though the number nine hundred thousand, given by Xenophon, ${ }^{4+}$ and four hundred thousand, as stated by Ctesias $^{45}$ and Diodorus, is evidently exaggerated. After these festivities were over, Artaxerxes gave a special feast of seven days to the inhabi-

40 Paton, p. 73, and numerous other exegetes, regard the gathering of nobles from all provinces for a feast of hundred and eighty days as intrinsically improbable.

${ }^{41}$ According to Xenophon (Cyropacdia, VIII, 2. 6), Susa was the winter residence of the Persian kings.

2 Artaxerxes, VI, I-2.

43 Siegfried, Wildeboer, Paton, \&c. believe that we have to read

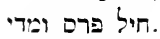

44 Anabasis, I, 7. I I-12. 45 Pers. 4I ; Diod. NIV, 5. 
tants of the capital, that is to say, each day of the week a different part of the population was invited. It may have been the farewell feast before the king's departure from Susa, or the New Year festival in the month of Nisan. On the seventh day, when not in a sober condition, the king ordered the eunuchs to bring to the banquet his queen Vashti 'to show to the people and the princes her Esther beauty; for she was fair to look on. But the queen I. 10-12. Vashti refused to come at the king's commandment by the eunuchs'.

For the interpretation of this incident we again refer to Plutarch who tells us: 'Artaxerxes married a beautiful and virtuous lady, by order of his parents, and he kept her when they wanted him to put her away. For the king having put her brother to death, designed that she should share his fate. But Artaxerxes applied to his mother with many tears and entreaties, and, with much difficulty, prevailed upon her not only to spare her life, but to excuse him from divorcing her.' ${ }^{46}$ Plutarch's source for this story is Ctesias who gives a more detailed account of this event in telling us that the whole family of Hydarnes, the father of Artaxerxes' wife, were put to death with the exception of the latter, on account of Teriteuchmes the son of Hydarnes, who had been found guilty of the crimes of adultery, incest, and murder. ${ }^{47}$ We must bear in mind, that by opposing the will of his parents, Artaxerxes might have easily forfeited his right to the throne, to which his claim, as we have seen, was questionable. It was very dangerous for Parysatis to let a woman whose whole family she had destroyed, have the power of a queen, and she indeed exerted all her influence with the king to

$$
\text { 4i. Avtaxirxes, II, 2-3. }{ }^{47} \text { Pers. } 29 .
$$


deprive him of the succession. But Artaxerxes cared more for his wife than for the throne.

Plutarch tells us further that this wife of Artaxerxes was a great favourite with the people: "What afforded the Persians the most pleasing spectacle was the queen riding in her chariot with the curtains open, and admitting the women of the country to approach and salute her. These things made his administration popular.' ${ }^{4}$ This queen and her mother-in-law detested each other, and quarrelled continually. When Cyrus rebelled, the queen openly upbraided her mother-in-law for her intercession by which she had saved Cyrus's life, and accused her of favouring the claim of the latter. ${ }^{49}$ When Parysatis executed in a most cruel way the faithful servants of the king who had killed Cyrus, the queen complained of her injustice and cruelty. ${ }^{50}$ "These expostulations fixed in the heart of Parysatis, who was naturally vindictive and barbarous in her resentment and revenge, such a hatred of the queen that she contrived to take her off. Deinon writes, that this cruel purpose was put into execution during the war; but Ctesias assures us, it was after it. And it is not probable that he, who was an eye-witness to the transactions of that court, could either be ignorant of the time when the assassination took place, or could have any reason to misrepresent the date of it; though he often deviates into fictitious tales, and loves to give us invention instead of truth.' ${ }^{1}$ 'It was only from the hatred and jealousy which Parysatis had entertained of the queen from the first, that she embarked in so cruel a design. She saw that her own power with the king

\footnotetext{
${ }_{48}$ Artaxerxes, V, 6.

${ }^{50}$ lbid. XVII, 9.
}

49 Ibid. VI, 6-7.

51 Ibid. VI, 8-9. 
depended only on his reverence for her as mother; whercas that of the queen was founded in love, and confirmed by the greatest confidence in her fidelity. The point she had to carry was difficult, and she resolved to make one desperate effort.' ${ }^{52}$ Plutarch further states that after Parysatis had managed to poison the queen, Artaxerxes inquired into the affair, and executed her principal attendants who assisted her to carry out this design. But 'as for Parysatis, the king did not reproach her with the crime, nor punish her any further than by sending her to Babylon, which was the place she desired to retire to, declaring that he would never visit that city while she lived.' 53 However, 'the ling did not long retain his anger, but was reconciled to his mother, and sent for her to court; because he saw she had understanding and spirit enough to assist in governing the kingdom, and there now remained no further cause of suspicions and uneasiness between them.' ${ }^{54}$

The queen represented in the Book of Esther, her great beauty of which the king was so proud, her great influence with the latter that she presumed upon his love to disobey his behest, cannot be better depicted than by Plutarch's description of the queen of Artaxerxes, the daughter of Hydarnes. Only a woman like the latter would act like Vashti, openly daring to disgrace the king in the presence of the people, presuming upon his love for her to obtain pardon for her disobedience. The queen of Artaxerxes evidently lost her life shortly after Cyrus's rebellion. But Plutarch's description of the method of her assassination is rather fabulous, and the deed itself seems improbable. We can hardly imagine that Parysatis should have dared

52 Ibid. XIX, I-2.

53 lbid. XIX, 8-1o.

54 lbid. XXII!, 2. 
to murder a queen with whom the king was so decply in love, and that the latter should not have reproached her with this crime, and should have been reconciled to her after a short time. Plutarch himself refuses to accept Ctesias's account that Parysatis plotted against the queen and resolved to carry her off by poison, because at her own request the king promised not to put Clearchus to death, but afterwards, persuaded by the queen, he destroyed all the prisoners, except Menon, and observes: 'But it is a great absurdity in Ctesias to assign so disproportionate a cause. Would Parysatis, for the sake of Clearchus, undertake so horrid and dangerous an enterprise as that of poisoning the king's lawful wife, by whom he had children and an heir to his crown?' 55 Hence, if we should accept Plutarch's account that Parysatis out of hatred of the queen did undertake 'so horrid and dangerous an enterprise', we must assume that the queen's position had undergone some change, before she was murdered; that in the meantime some incident occurred which to a certain degree estranged the king from the queen. Parysatis, seeing that the love of the king for his queen was no longer so strong as before, and being afraid lest the latter should regain her former influence, resolved to murder her. The fact that the king, after a short banishment, recalled her, shows that she had not been wrong in her reasoning.

Plutarch further states, 'None had been admitted to the king of Persia's table but his mother and his wife; the former of which sat above him and the latter below him. Artaxerxes, nevertheless, did that honour to Ostanes and Oxartes, two of his younger brothers.' ${ }^{56}$ This statement shows that it must have been a very rare privilege to dine 
with the queen..$^{57}$ A special feature of his character was his great vanity, claiming credit for actions which he never did and for qualities which he did not possess. He was desirous of having the world believe that Cyrus was lilled by himself. ${ }^{58}$ When Mithridates, the real slayer of Cyrus, to whom Artaxerxes owed his life and throne, in an unguarded moment, under the influence of wine, boasted of his deed, he was put to death in a manner that beggars description. ${ }^{59}$ Artaxerxes also put many grandees to death, because 'he thought that they despised him for the ill-success of his campaign.' ${ }^{60}$

For the interpretation of the incident of Vashti, we must call attention also to another point. We have

57 Plutarch's statement that none had been admitted to the king of Persia's table but his mother and his wife, is quoted by Paton, p. 150, as proof that it was not Persian custom to seclude the women, in observing: 'Stateira was present at the table of Artaxerxes'. Paton's quotation of Herodotus IX, IIo, in support of his contention that Persian queens were present at the royal banquets, is just as incorrect. Amestris was at the birthday feast of Xerxes, but Herodotus clearly implied that the latter did not dine with the people, as it is incredible that Amestris would have dared 'to weary Xerxes by her importunity' in the presence of the people. Even Masistes, his own brother, was not present at his table, as he was afterwards called into his presence. Paton further quotes Herodotus, V, r8, where the Persian ambassadors say to Amyntas, king of Macedonia, that the Persians bring their wives and concubines to the feasts. But it is evident, as G. Rawlinson (ad loctm) rightly observes, that the Persian ambassadors presumed upon the Greek ignorance of Persian customs, in order to amuse themselves with the foreign women. They had indeed to atone with their lives for their conduct, as Alexander, Amyntas's son, well knew the Persian customs, and divined their intentions. Paton and others overlook what Plutarch says about the Persians that they 'are so extremely jealous of their women, that capital punishment is inflicted, not only on the man who speaks to, or touches one of the king's concubines, but on him who approaches or passes their chariots on the road' (Artaxives, XXVII, I).
6) Ibid. X1V, 5 .
59 Ibid. XV, XVI.
${ }^{60}$ Ibid. $\mathrm{XXV}, 3$. 
already mentioned that under the reign of Artaxerxes II the baleful influence of the harem made appalling progress. The rule of the harem was indeed the main curse of the Persian empire. The king was a mere tool in the hands of his favourite wives. The most meritorious grandees fell victims to their intrigues. No Persian could regard himself for one moment secure, if one of the favourite wives or her family bore him ill will. Such a man, his life being in danger, was easily persuaded to conspire against the king or join an insurrection. The patriotic statesmen must have perceived that such a condition was disastrous to the existence of the empire, and were desirous of eliminating the influence of the women. IVe may also reasonably suppose that the feminine influence at the court set a bad example to all Persian families. ${ }^{61}$ These statesmen were wrong in believing in a remedy for an incurable evil. A man of weak character, be he ling or beggar, will always yield to his wife's influence, for good or evil.

We return now to the incident of Vashti: The king, as we have seen, was deeply in love with the queen, and exceedingly proud of her beauty. Having been under the influence of wine-and from Cyrus's letter to the Lacedae-

61 Paton, p. 162, observes: "The absurdity of the solemn edict commanding the wives to obey their husbands struck even the doctors of the Talmud'. The latter might have been right, if they had ridiculed the idea of making the husbands masters in their own houses by a royal edict. But in remarking that 'even the weaver is master in his own house', they were decidedly wrong. However, Paton and the rabbis overlooked the fact that the royal edict does not say anything about the obedience of the wives to their husbands, but merely contains the fundamental principle, 'that every man should bear rule in his own house ', which of course gives the husband power also over his wife. Such a general principle is by no means ridiculous, since it formed one of the fundamental Roman laws, as set forth in the Twelve Tables, according to which the life and liberty of children were in the father's hands. 
monians we learn that Artaxerxes II did not possess the Persian 'virtue' of being able to consume great quantities of wine without becoming intoxicated-the king commanded the queen to come and partake of the feast, that the guests might admire her beauty. The queen, however, being 'a virtuous lady', as Plutarch expresses himself, and well aware that that request was not in accordance with the Persian customs, properly inferred that the king in his right senses would never have made such a request, and rightly refused to show herself in the presence of an intoxicated crowd. Artaxerxes, exceedingly vain, and ashamed to admit that he was under the influence of his wife, 'was very wroth and his anger burned in him'. The thought might have occurred to him, having no authority in his own palace, how could he expect the people to obey his commands? The queen's disobedience could not pass with impunity.

'Then the king said to the wise men which knew the times.... and the next unto him ..... the seven princes of Persia and Media, which saw the king's face and which sat the first in the kingdom: "What shall we do unto the queen Vashti according to law, because she hath not performed the commandment of the king Ahasuerus by the eunuchs?"' The royal councillors to whom this question was addressed were well acquainted with the weak spots in the king's character and with his love for the queen. This question put them in a most embarrassing situation. Considering the queen's disobedience from a purely moral point of view, they could not but admit that under the circumstances her conduct was justifiable. Yet to defend her action would have been nothing short of high treason. The authority of the king was indeed at stake, if the queen 
should be acquitted. It was the latter's duty to comply with the king's behest, even if it was not in accordance with the Persian customs. Besides, if we may believe Herodotus, the Persian kings were not bound by customs, as there was an ancient law decreeing that the king of Persia might do whatever he pleased. ${ }^{62}$ Moreover, it was not for the councillors to decide the guilt of the queen. The question put before them was merely concerning the punishment that should be meted out to her. This was a very difficult problem. They did not want to condemn her to death, lest after a short time the king's yearning for his lost queen might return, and they would have to atone with their lives for their judgement. ${ }^{63}$ They feared the same fate, if they should propose her divorce, as nothing would prevent the king from marrying her again, if he still loved her, and the queen, after regaining her power, in her resentment against them, might easily bring about their destruction. If they should condemn her to the loss of the rank of a queen, it was probable that she would soon regain her former influence with the king, without the royal rank, and again would not fail to avenge herself upon them. Yet the latter course was the lesser evil and the only way out of this dilemma. Therefore, the councillors condemned her to the punishment of degradation for her conduct. But this queen, as we have scen, was a great favourite with the people. It was not enough to hold up the authority of the king, but also to demonstrate the justice of her punishment. Artaxerxes' administration

62 Herodotus III, 31 .

63 The Targumim indeed say that after sleeping of his wine-debauch and having grown sober, Ahasuerus executed the councillors who advised him to put Vashti to death.

H. 
was very popular, as we have seen, and they did not wish that by their advice the king should lose his popularity. Besides, no king at the beginning of his reign likes to gain the reputation of a tyrant. Hence, the councillors represented the queen's offence as a danger to the well-being of the empire, saying: "Vashti the queen hath not done wrong to the king only, but also to all the princes, and to all the people that are in the provinces of the king Ahasuerus. For this deed of the queen shall come abroad unto all women, so that they shall despise their husbands in their eyes, when it shall be reported, the king Ahasuerus commanded Vashti the queen to be brought in before him, but she came not. Likewise shall the ladies of Persia and Media say this day unto all the king's princes, which have heard of the deed of the queen. Thus shall there arise too much contempt and wrath.' The councillors, therefore, advised the king to promulgate the degradation of the queen by a decree, in proposing: "If it please the king, let there go a royal commandment from him, and let it be written among the laws of the Persians and the Medes, that it be not altered, that because Vashti came not before the king Ahasuerus, the king shall give her royal estate unto another that is better than she.' Such a decree would have the effect of making the lives of the Persians more secure at the court and more peaceful at home. ${ }^{\text {it }}$ The

64 The clause עa is is isenerally regarded as corrupt. The rendering of the English version : 'and that it should be published according to the language of every people', is of course quite impossible. We have already mentioned that the Greek version omitted this clause (see Chapter I, n. 8). Berthcau-Ryssel, Wildeboer, Siegfried and others emcnd it, with Hitzig, to 'what suits him'). These commentators could have saved themselves the trouble of emending this corrupt clause, if they had seen how such a corruption might have occurred. We may assume 
councillors of course could not mention the deplorable state of harem-rule at the court, but only the latter's effect: 'And when the king's decree, which he shall makc, shall be published throughout all his empire, for it is great, all the wives shall give to their husbands honour, both to great and small'. This affair undoubtedly caused an estrangement and a bitter feeling between the king and Vashti. The former could not get out of his mind the humiliation he suffered in the presence of his subjects, and the latter was indignant at the injustice of her degradation. Parysatis, taking advantage of this state of affairs, resolved

that there were manuscripts in which the ammitim ran in the following lines:

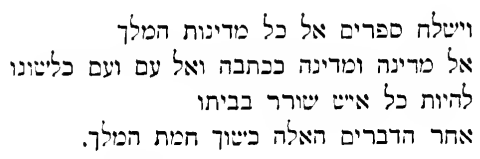

ויעם =ליטונו or made a blot on them, and not having had the proper means handy to erase them, wrote the same words again underneath in the following line, after the words להייות בל אי": ישורר בביתו. as between the first and second chapters there was in all probability a free space. Subsequently, some copyist read להיות כל אי״: ישורר בביתו ועם כלישונו, and understood the passage to mean: 'That every man should bear rule in his own house, and every people according to its uwn language'. But as the passage in this construction did not seem to give a proper sense, he may have changed the

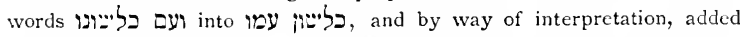
the marginal gloss ומרבר. Haupt (Critical Notes, p. 13r), considers the whole clanse a late gloss, since in Talmud Babli Megillah $12 \mathrm{~b}$ the passage I. 22 is discussed, but there is no reference to this clause. But this fact is no proof at all that the rabbis did not know this passage. They did not discuss it, because it seemed to them incomprehensible. We cannot expect them to suggest that this clause was a gloss or corruption. Moreover, a suggestion that a gloss was added in post-talmudic times, when the Book of Esther had been already for hunclreds of years one of the most esteemed canonical bouks, deserves no consideration w'hatever. Finally, a gloss is supposed to have some sense, and this clause has none at all. 
to put her out of the way, lest the king might be reconciled to his wife and she regain her former power. ${ }^{65}$

We are well aware of the fact that our interpretation is not in accordance with the text under discussion, which

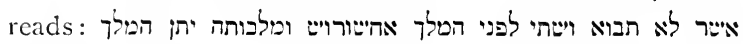
לרעותה העובה :'מינה : that Vashti come no more before king Ahasuerus, and the king shall give her royal estate unto another that is better than she'). Accordingly, the text distinctly states that Vashti was actually divorced and not merely degraded from the rank of a queen. However, by a critical analysis of this passage we can demonstrate that the text here must be slightly corrupted. If the promulgation of Vashti's punishment was intended to have a salutary effect upon the conduct of the Persian women for all times, we would expect to find in this edict 'written among the laws of the Persians and the Medes', the cause of her punishment. Furthermore, the second part of this passage is quite superfluous, it being a matter of course for the king to choose another queen, if Vashti was divorced, and cannot be a part of the edict; why should such a trivial fact be written among the laws of the Persians and the Medes? Nor can it have been the advice of the councillors, as this was unnecessary. The original reading of this passage may have been something like (על) אישר לא באה ו"שת לפני המלך אה'שורויש מלכותה יתו המלד because Vashti came not before the king Ahasuerus, the king shall give her royal estate unto another that is better than she'; but the original reading

6: Plutarch's statement that shortly before the murder of Stateira, the latter and Parysatis had. in appearance, forgotten their old suspicions and animosities, and began to visit and eat at each other's table, implies that the queen no longer interfered with her mother-in-law (Avtaxerxes, XIX, 5 . 
אישר לא תבוא could also mean : 'because she will not come'. In either case, the text, according to our emenclation, would contain both cause and effect, and be in agreement with our presentation of that incident. Vashti lost only her rank as queen, but still remained the lawful wife of Artaxerxes. ${ }^{56}$

There is still another point to be discussed. The name of the queen of Artaxerxes II was not Vashti, but Stateira. Plutarch is no doubt right on this point, as Ctesias who lived at the court of Artaxerxes must have known the name of that queen. As far as the other Greek writers are concerned, all of them are more or less dependent upon Ctesias, and they took over the name of this queen from the latter. The name of the queen was indeed Stateira, but having been a famous beauty and a great favourite with the people, she was styled Vashti, which, as was recognized long ago, ${ }^{67}$ means in the Persian language 'beauty'. In the memory of the people, her proper name was displaced by this epithet. We have a classic example of such a phenomenon in the name of the famous Greek woman who lived in Egypt under the reign of king Amasis. Her real name was Doricha, yet Herodotus and other classic writers call her by her epithet Rhodopis, 'the rosycheeked', though they knew that Sappho mentioned her by her real name. ${ }^{68}$ Our author may likewise have known that the queen's real name was Stateira, and nevertheless preferred to call her by the widely-known epithet Vashti.

66 Renan, in his History of the Pcople of Israel, VIII, I5, note, is the only historian who conjectured that 'possibly there is some reminiscence of Stateira and Parysatis'.

67 Cf. Richardson's Uebcr morgcnländischc Völkcr, 1779, p. 166; Cassel, l. c., p. 27, and Justi, Iran. Namcnb., under 'Wasti'.

68 Herodotus II, 134-5, and cf. G. Rawlinson, n. 2, ad locum. 
Howerer, the possibility that I'ashti is a hypocoristicon of a compounded name Sta-teira = Asta-teira = Mashtateira, which may mean 'the beauty of the god Mercury', ought also to be considered. ${ }^{69}$

We have already observed that Plutarch is silent as to the immediate successor of the assassinated queen. Ctesias may have known nothing about it, as he left the court about $39^{8}$ B.C.E. ${ }^{70}$ But the former states a fact that

69 The name Stateira is, according to Justi, Iran. Namenb., compounded of the two elements sta and teira. The latter element is evidently identical with $t \vec{\imath} \cdot$ in the Persian personal names Teribazus, Teridates, Teriteuchmes, \&c., which is generally taken by Justi and others to be the Persian name of the planet Mercury (as god, the seribe of Ahuramazda, and identical with $N a b n)$. The same divine element we may see in the names Aghrinatteira, Batshat-teira, and Pairish-teira. Doubtful, however, is the meaning of the first element sta. The latter occurs also in two other Persian names $\Sigma_{\tau \alpha \mu \dot{\epsilon}^{\prime} \eta \eta}$ and $\Sigma \tau a \beta a \dot{k} \eta \bar{s}$, the meaning of which is, aceording to Justi, doubtful. We suggest that the name Sta-teira corresponds to the Persian name Vashta-teira. The name Vashti is rendered in the Greek version into ${ }^{*} \mathrm{~A} \sigma \tau \iota \nu$ and $" \mathrm{~A} \sigma \tau \iota$, in which the first radical is represented by a vowel. The same rendering is found also in other Persian names, as Vidama = 'I $\delta$ '́ $\rho \nu \eta$ ',

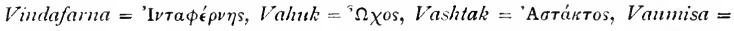
' $\Omega \mu \iota \sigma o s$, \&.c. Lucian's rendering of Vashti into Ováarıv and that of Josephus

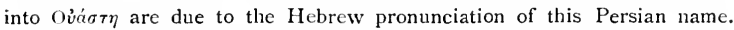
Now the element asta is actually found in several Persian names, as in 'A $\sigma \tau \iota \beta a \sigma \alpha s$, 'A $\sigma \tau a ́ \sigma \pi \eta s$ Aescliylus, Persae 22), and 'A $\sigma \tau \eta$ s. The same

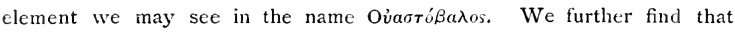
a vowel at the beginning of a name was regarded as prothetic; so we find

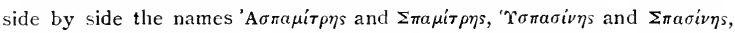

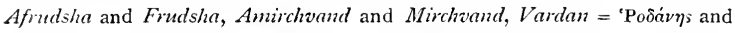
'Opórin Persian name Vashta-tcira was rendered by the Greeks into Asta-teira, and by treating the first vowel as prothetic, was also pronounced Sta-teira. The Babylonians, however, shortened this compounded name by omitting the second element and by attaching to the shortened name the Babylonian hypocoristic termination $\bar{i}$.

7 His departure from the eourt may have had some connexion with the barishment of Parysatis, who was a friend of Clearehus whom Ctesias so greatly admired Phutarch, Aitaxeres, XVIII). The latter may have been her protige. 
somewhat seems to corroborate the incident of the second chapter of Esther: 'Artaxerxes had three hundred and sixty concubines, all women of the greatest beauty'.il This reminds us of the gathering of the virgins for the selection of a successor of Vashti. Now, it is true, Diodorus Siculus tells us exactly the same about Darius III. ${ }^{i 2}$ And all Persian kings had a large number of concubines. But the current interpretation of the incident of the second chapter is erroneous. The royal harem could not have been maintained without having taken into it, either by force or with the consent of their relatives, the daughters of the subjects. From time to time such a harem had to be replenished and rejuvenated by younger women. ${ }^{73}$ The advice about the gathering of the virgins was not an innovation under the reign of Ahasuerus, as such gatherings were customary in the Persian empire. The author of our story merely intends to inform us that on the occasion of such a gathering Esther became the queen of Aliasuerus. The latter, when his wrath was appeased, 'remembered Vashti, and what she had done, and what was decreed against her'. Remembering now that she was unjustly condemned and publicly disgraced, his love for her revived, and he mourned her loss. Among the women of his harem, there was none the equal of his lost wife in beauty and other qualities, who could replace her. Nor was there among the high nobility with whom the royal family was wont to intermarry such a woman to efface in the heart of the king the image of the former queen. Therefore

i) Artaxerxes, XXVII, 5 .

72 Diodorus XVII, 8.

7. See n. 12. Diodorus indeed alludes to such gatherings in saying that these three hundred and sixty women were the greatest beauties that could be found throughout Asia. 
the courtiers advised the king that such a customary gathering of virgins should be held now-though the need of the harem may not have required it, or it may not have been the usual period for such a gathering-and among those gathered might be found one woman who would be in every respect equal to Vashti. It was by no means necessary that such a woman should succeed the latter as queen. But from the king's weak character it was a foregone conclusion that the latter would bestow on her the highest rank, if she succeeded in completely obliterating in his heart the memory of his former wife. The courtiers in saying: 'Let the maiden which pleaseth the king be queen instead of Vashti', may have alluded to the agreement of Darius I with the other conspirators, that the Persian kings should not marry outside of their own families, and advised the king to disregard this agreement, which under present circumstances became invalid; since of these noble families there was none worthy of taking the place of Vashti.

Of further interest for the character of Artaxerses II is Plutarch's account of his return from the campaign against the Cadusians: "He found on his arrival at his capital that he had lost many brave men, and almost all his horses; and imagining that he was despised for his losses and the ill-success of the expedition, he became suspicious of his grandees. Many of them he put to death in anger, and more out of fear.' it Though the expedition against the Cadusians took place in a later period of his reign, and therefore these executions have no connexion with our story, nevertheless this conduct sheds light upon this ling's character. A king who puts to death many 
grandees in anger, and more out of fear, was quite capable of executing his prime minister Haman, his sons and partizans, for the same reason. No less characteristic of this king is his treatment of Tissaphernes. The latter had saved his life at Pasargadae and watched all the movements of Cyrus, informing the king of his designs, as already mentioned. Plutarch calls him 'the most implacable enemy of the Greeks', ${ }^{75}$ and thus, from a Persian point of view, he must have been the most ardent patriot. His final reward was to be executed upon charges preferred against him by his greatest enemies, the Greeks and Parysatis. ${ }^{i 6}$

In support of our contention that Ahasuerus of Esther is identical with Artaxerxes II, we may call attention to the following fact. The French Archaeologist Dieulafoy describes the ruins of Susa, and demonstrates that the description of the palace of Ahasuerus in the Book of Esther is absolutely correct. ${ }^{77}$ But the palace to which this scholar refers is not that of Xerxes but that of Artaxerxes II. The palace in which Xerxes and his successors resided had been destroyed by a fire and was rebuilt by Artaxerxes II, as the latter in his inscription informs us. ${ }^{78}$ Who knows whether the palace of Xerxes, dating from an early period, was not in many points different from that given in our story ? ${ }^{79}$

We may mention also a remarkable statement of Bar Hebraeus in his Chronicles: 'This Artaxerxes (II) the

${ }^{75}$ Artaxerxes, XXIII, I.

${ }^{75}$ lbid., 2.

77 M. Dieulafoy, L'Acropole de la Susa, i8go.

i8 Die altpersischen Keilinschriften, p. 45.

${ }^{79}$ Paton, p. 65 , also observes: 'The palace of Xerxes, as described in Esther, is not unlike the palace of Artaxerxes Inemon, as excavated by Dieulafoy at Susa. 
Hebrews call Ahasuerus; and therefore Johanan was of the opinion that the story of Esther occurred in his days'

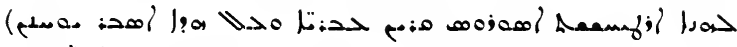

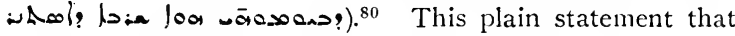
Artaxerxes II was by the Hebrews called Ahasuerus must rest upon some tradition still preserved in the days of Bar-Hebraeus (c. 1250 C.E.). On the basis of this tradition, and for no other reason, Johanan suggested that the story of Esther occurred under the reign of Artaxerxes II, seeing in this story a similar phenomenon that the Ahasuerus of the Hebrew text is in the Greek version called Artaxerxes.

Having now sufficiently demonstrated that the king described in the Book of Esther was Artaxerxes II, we have to explain why the Hebrew text should contain a fictitious name. The solution of this problem may be found by a comparison of the political careers of the two Persian kings Xerxes I and Artaxerxes II, and by taking into account historical events in a later period of the Persian empire.

No nation cherishes the memory of a ruler by whom it was humiliated. The memory of Xerxes was no doubt detested by the Persians in a later period, after the passing of the Achaemenian dynasty, when they looked back at their glorious past, and could freely express their opinions about the happenings of those times. After four years of preparations, with enormous forces at his command, Xerxes was disgracefully defeated several times by the comparatively small army of the Greeks, and in consequence of these defeats, lost the Greek cities of Asia Minor, Thrace, and Cyprus. By these misfortunes Xerxes put 
upon the haughty Persians the stigma of cowardice. The later Persians could vindicate the honour of their ancestors only by laying the blame for these defeats on Xerxes, contending that they were not due to any lack of courage in the Persian armies, but to the misfortune of having been under the command of an incapable ruler. The disparaging description of Xerxes's personality by late classical writers may have had its source of information in the Orient. No Persian would have objected if Xerxes was represented as a weak character.

The condition of the Persian empire, as far as its foreign relations were concerned, exhibited under the reign of Artaxerxes II a sharp contrast to that under Xerxes. The memory of the former, who humiliated the hereditary enemies of the Persian empire and vindicated its honour, could not but be sacred to every Persian. The legend mentioned above, that in honour of Artaxerxes II, the Persians decreed that all his successors should bear the name Artaxerxes, must have its origin in the Orient in a period when the Persian history of the Achaemenian empire was no longer well known. The names Arses and Darius III, who succeeded Artaxerxes III, were sunk in oblivion. But Artaxerses II was a name never to be forgotten.

The Persian empire overthrown by Alexander the Great was, after an interruption of about eighty years, resurrected in the year 248 B.C.E., though under another name, Parthia. The founders of the Parthian empire, Arsaces and Tiridates, and their successors traced their lineage to Artaxerxes II, and based upon it their claim as rightful heirs to the empire of the Achaemenians,"1

"1 Sce Justi, Iran. Namenb., p. 28. Ed. Meyer (Encycl. Brit., under Arsaces' says: 'A later tradition, preserved by Arrian, derives Arsaces 
though this claim may have no real foundation. The representation of the alleged famous ancestor of the Parthian kings as a weak character, and the recital about him of uncomplimentary details in the Jewish sacred writings, was not without danger for the Jews in the East, and may indeed have been the cause of persecutions. We must bear in mind that the Parthian empire was established in the Alexandrian age, when the Jewish writings were being rendered into Greek. The Parthians were somewhat imbued with Greek culture. The Arsacids even founded Greek cities. When Arsaces Mithridates conquered Babylon, he assumed the epithet Philhellene. ${ }^{82}$ The hostile attitude of the Greeks towards the Jews in the second century B.C.E. was no doubt just as intense in the East under the Arsacids as in the West under the Seleucids. The presumption that Greeks actually accused the Jews of slandering publicly and annually the memory of the famous ancestor of the Parthian kings, whose name ought to be sacred to everybody, is very likely. Therefore the Jews were compelled to choose between two alternatives: either to suppress the Book of Esther altogether and at the same time abolish the festival of Purim, or to change it in such a way that it might not be offensive to the national feeling of the inhabitants of the Parthian empire. They naturally preferred the latter course, and substituted

and Tiridates from the Achaemenean king Artaxerxes 1I. But this has evidently no historical foundation'. This historian is no doubt right, if he means that this tradition is without historical foundation. But there can be scarcely any doubt that the Arsacids did claim to be the lineal descendants of Artaxerxes II. Arrian certainly did not invent this tradition. It would have been without historical analogy, if they had not claimed to be the descendants of an ancient royal family.

*2 See Ed. Meyer (ibid.) and Justi, Geschichte, p. ${ }_{4} 8$. 
in the Book of Esther, for the name of Artaxerxes, the name of Ahasuerus (= Xerxes), which could be used with impunity.

The substitution of the name Ahasuerus was quite natural. Besides, the Jews had no other choice among the names of Achaemenian kings. Those of Cyrus and Darius could not be considered for this purpose, as they were sacred to the Jews, and even more so than to the Persians. The names of Cambyses and Arses were out of the question, as these kings did not rule twelve years. Nevertheless, the name they substituted is remarkable, as there is reason to assume that the proper name of Artaxerxes II was Ahasuerus. If this is true, it is either a coincidence, or the Jewish leaders in the East, in the second century B.C.E., must have known more about Persian history than we are willing to give them credit for. The name Artaxerxes was not a proper name, but a title, and means 'he whose empire is well fitted, or perfected ', $\$ 3$ which was assumed by the kings Artaxerxes I, II, III, on their accession to the throne. From an astronomical cuneiform tablet dated 'in the twenty-sixth year of Arshu, who is Artaxerxes' (Arshu sha Artakshatsu) ${ }^{\text {st }}$ we learn that the proper name of Artaxerses II was Arshu. This evidently confirms Deinon's statement that his name was Oarses. Plutarch. however, does not accept this statement, and observes: 'Artaxerxes at first was named Arsicas (or Arsaces), though Deinon asserts that his original name was Oarses. But though Ctesias has filled his books with a number of incredible and extravagant fables, it is not probable that

${ }^{83}$ See Ed. Meyer, Encycl. Brit., under 'Artaxerxes', and Justi, Iran. Namenb.

* Strassmeier, in Zeitschrift f. Assyriologie, VII, p. I $_{4} 8$. 
he should be ignorant of the name of a king at whose court he lived, in quality of physician to him, his wife, his mother, and his children'. ${ }^{85}$ But Plutarch did not know that both names, Oarses and Arsaces, are identical. The name Arshu = Arses = Oarses = 'man.' The suffix $k \in k(a)$ is a Persian hypocoristic termination. ${ }^{86}$ Thus Arsaces (Arsicas) is a hypocoristicon of Arshu. But hypocoristic terminations, as a rule, are affixed only to shortened names. ${ }^{87}$ What may have been the original compounded name of Artaxerxes? The name Xerxes = Persian Khshaj'ärsha = Babylonian Khi-sha-ar-shu means 'a mighty man, warrior, hero'. It was not a title, like Artaxerxes, but a proper name. In antiquity, especially among the Aryans, a proper name was the expression of the bearer's personality. ${ }^{8 s}$ The bearer of a name 'Mighty man' had to live up to its meaning, and could not be a coward. Both Darius I and Artaxerxes I gave the name Khshayärsha to the legitimate heirs of the throne. Darius II, though he had not yet been ling at the birth of his eldest son, may have nevertheless imitated their example and named his first-born son Khshajārsha. But the first royal bearer of this name was murdered. When the same fate happened to the second royal bearer of this name, it may have become ominous. Besides, this name may have become unpleasant to the ears of Darius Il, who occupied the place of his murdered brother, Xerxes II. Hence Darius

${ }^{85}$ Arta.icr:xes, 1,4 .

\&6 Justi, Iran. Namonb., Einleitung.

87 See ibid. It is quite possible that in a later period the name Arsaces was treated like a regular name and lost its hypocoristic signification. But the fact that Artaxerxes is called Arshu in the Babylonian document leaves no doubt that Arsaces was a hypocoristic formation.

88 Cf. H. Ranke, Die Pirsonemnamen i. d. Lrkund. d. Hammurabidynastic, 1902, p. 2. 
may have shortened his son's name Khshayārsha to Ársha and affixed to it the hypocoristic termination $k \epsilon(k a)$. But in official documents this name was written without the hypocoristic suffix. ${ }^{89}$ The Jews who had many eunuchs at the Persian court, of whom some appeared to have been leaders in Israel, may have been better informed of these details than the Greek classical writers. These court stories may have been handed down, so that the original name of Artaxerxes II was still known in the second century B.C.E. and even later.

Outside of the Parthian empire, in Syria and Palestine, the original name Artaxerxes has been preserved in the Book of Esther. The rabbis, who fixed the Canon, aimed of course at uniformity of the Scriptures. But the Jews in the East could not accept the name Artaxerxes.-And there can be no doubt that the fixing of the Canon was done with the co-operation and approval of the Eastern rabbis, though we have no information whatever how this work was done.-Therefore the Western rabbis had no other choice but to accept the reading, Ahasuerus. Hence the Greek version which undoubtedly ante-dates the fixing of the Canon,,$^{90}$ has the original name Artaxerxes. But the Lucianic recension made towards the end of the third century C.E. preferred the reading of the Hebrew text and rendered it 'Arúnpos. Josephus follows as usual the

.9 We might even suggest that the title Arsaces of the Parthian rulers was not assumed in honour of the founder of this empire, but to assert their descent from Artaxerxes whose proper name was Arsaces. It is even possible that the very name of the founder of the Parthian empire was assumed in honour of his alleged ancestor. The former ruled only two years, and his dominion was insignificant, as it was limited to his native land Parthia.

90 Cf. Chapter I, n. 9 . 
Greek Version and has the correct name Artaxerxes, but identificd this king with Artaxerxes Longimanus. ${ }^{91}$

91 Josephus may or may not have known that the name Ahasuerus in the Hebrew text was due to 'the correction of the Scribes' (תקון סופרים). But this question is quite irrelevant, as his chronology of the Persian period is not to be relied upon. In presenting Ezra as a contemporary of Xerxes, Josephus follows neither the Hebrew nor the Greek text. This error is no doubt due to his wrong identification of the king of Esther with Artaxerxes Longimanus. The latter, according to Ezra 7, was very favourably inclined towards the Jews in the seventh year of his reign. Therefore it seemed to Josephus incredible that the same king should have decreed five years later their destruction, and he concluded that the king of Ezra was Xerxes. 


\section{CHAPTER V}

The term 'Judeans'-The renascence of Isracl's religion-National aspirations-The religious propaganda among the exiles-Religious creeds and the conduct of their adherents-The hatred of the Babylonian exiles towards Babylonia-The attitude of the Judeans in Egypt towards this country-The conduct of the wealthy Judeans in Babylonia-The cause of persecutions-The Judeans' attitude towards the Persians-Zoroaster's 'monotheistic' religion-The eharacters of Mordecai and Esther-The two opposing tendencies within Judaism-Mordecai versus Ezra and Nehemiah -The effect of the religious persecutions-The predicament of the Sopherim-The omission of all religious elements in the Book of EstherThe attitude of the Rabbis towards this book-The omission of the names of Mordecai and Esther in Sirach's Fathers of the IVortt.

In the preceding chapter we have demonstrated that the Ahasuerus of the Book of Esther is to be identified with Artaxerxes II. Now it remains to prove that the main event of our story actually occurred under that king's reign. Before, however, proceeding to deal with that event, it is indispensable to outline the conditions and the character of the Jews during the Babylonian captivity and the Persian period; for the misinterpretation of the Book of Esther in ancient and modern times is mainly due to misconception on those points. In the first place we have to investigate the term 'Jews' (יהודים).

In pre-exilic times, the inhabitants of the kingdom of Judea, irrespective of their descent, had been termed 'Jews ' II. 
(יהורים). Even those who werc worshippers of Baal, Moloch, or Astarte, who were the citizens of that country, werc nevertheless called 'Jews'. This appellation was used without the least regard to their beliefs. The practice of idolatry did not deprive any one of his nationality. On the other hand, Gentiles who had adopted the religion of Jahveh, but had not become inhabitants of Judea, were, of course, not called 'Jews' (יהורים), and still remained members of their own nationality. ${ }^{2}$ Thus the term 'Jews' had not the least religious significance.

What were the criteria of the Judean nationality of the inhabitants of Judea who had bcen carricd into the Babylonian captivity, or had migrated to Egypt? The Hebrew language ${ }^{3}$ and the national consciousness! But

1 The term יהורים (2 Kings 16.6; 25. 25; Jer. 32. 12, \&c.), includes all inhabitants of Judea, even those who did not belong to the tribe of Judah (cf. Ges.-Buhl's Hwb., p. 3II).

${ }^{2}$ It goes without saying that the worship of Jahveh, as generally practised by the people in the pre-cxilic period, was not restricted to the state of Judea, and thus was not characteristic of the inhabitants of this country. There were the inhabitants of Samaria who claimed to be worshippers of Jahveh (Ezra 4. 2). The name Jaï-bi'di of the king of Hamath points to the existence of that worship in the latter country. In this fact we may see a corroboration of the reading Joram, the name of the son of the king of Hamath (2 Sam. 8. ro), of which we find the variant Hadoram (I Chron. 26. 25). The name Azri-jau of the king of Ja'udi (cf. Winckler, Altorientalische Forsehtungen, I, 'Das Syrische Land Jaudi und der angebliche Azarja von Juda') leaves no doubt that the Jahveh-worship existed in the latter country. But we may wonder whether it is a mere coincidence that the name of that country is identical with that of Judea, in the cuneiform inscriptions, and that in both countries the Jahveh-worship is found. Who knows whether there is not after all some ethnological connexion between these two countries. For the legal status of foreigners among the Jews ef. Ed. Meyer's Entstehung des Judenthums, pp. 227-34.

s Hcbrew was still the national tongue, as in the period of Hezekiah (2 Kings 18. 26), and had not yet been superseded by Aramaic, as we may learn from the words of Ezckiel: "For thon art not sent to a people of 
on a foreign soil these distinctive marks could not have endurcd for a long period. The succeeding generations, born in those countries, could not but adopt the idiom of the population among whom they were dwelling, with whom they were in intercourse. Their own national tongue was scarcely of any use in their daily pursuits, and this fact must have been detrimental to its preservation. Nor could the national consciousness of those generations survive for a long space of time. Gradually it must have evaporated. There was nothing that should have prevented the descendants of those captives or immigrants from being absorbed in the nations among whom they dwelt. Their assimilation with the latter seemed to have been inevitable.

The complete disappearance of the remnant of Israel was averted by the renascence of the Religion of Israel. The religious ideas, propagated by the prophets of the captivity and a small number of zealous Jews, made rapid progress, not only among their own fellow captives of Judea, but also among Gentiles. The result of that religious movement apparently was the preservation of the Jewish nationality. But as a matter of fact, a new principle was now being proclaimed. This did not result in restoration, but in reform of the Jewish nationality. Henceforth, neither descent, nor language, but religion, was the criterion of 'Jews'. However, the religion the exilic prophets resurrected could not be restricted to the narrow bounds of the Jewish nationality. The national barrier had to be removed, and every one was invited to a strange speech and of a hard language, but to the house of Israel, (Ezek. 3. 5). Even after the return from the captivity, Hebrew continued to be the common language, as we may adduce from the words of Nehemials (13. 24), that the offspring of those who married non-Jewish wives could not speak the Jews' language. 
cnter into this religious union and was gladly received. Those who accepted this invitation, and entered into the Covenant of Isracl, became at the same time 'Jews' (יהודים). Consequently, the Jewish nationality disappeared from the scene, and its place was taken by the Jewish religious community. ${ }^{4}$ The latter included, on the one hand, all adherents of the Jewish religion, even Gentiles, and, on the other hand, excluded all idolaters, even those who belonged to the Jewish race. ${ }^{5}$

There were, indeed, Jewish patriots who thought differently. They saw in the religious movement an effective force for the Jewish national resurrection, whose preservation could be effected only on a racial basis. These claims could not but deeply hurt the feelings of the newlyconverted Gentile, who bitterly complained: 'The Lord hath utterly separated me from His people'. ${ }^{6}$ But those national aspirations were nipped in the bud by the great

${ }^{4}$ Ed. Meyer (Gesck. d. Alt., I1I, p. 183) arrives at the same conclusion, but from a point of view which the present writer does not share, in observing: "The community is no longer national, but had become a religious association which makes propaganda and enlists adherents among foreign tribes.' Cf. also his Entstehung $d$. Jud., p. $233 \mathrm{f}$. He points to the large number of proselytes in the Greek and Roman periods. The Semites of the Western countries, who were captives like the Jews, may have associated with the latter rather than with the Babylonians, and thus were easily persuaded to embrace their creed.

בני נבר 5 We shall see further below that the latter were designated as 'sons of the stranger'.

${ }^{6}$ Isa. 56. 3. There must have been a national party which was dissatisfied with Ezekiel's declaration, that the proselytes should become equal citizens in the land restored to Israel, who said: 'And it shall come to pass that ye shall divide it by lot for an inheritance unto you, and to the strangers that sojourn among you, which shall beget children among you: and they shall be unto you as born in the country among the children of Israel. They shall have inheritance among you among the tribes of Isracl' (Ezek. 47. 22). 
exilic prophet, the so-called 'Second Isaiah', who proclaimed: 'Also the sons of the stranger which join themselves to the Lord to serve Him, and to love the name of the Lord, to be His servants, every one who keepeth the Sabbath from polluting it, and taketh hold of my covenant. Even them will I bring to my holy mountain, and make them joyful in my house of prayer; their burnt offerings and their sacrifices shall be accepted upon mine altar; for mine house shall be called a house of prayer for all people'? In accordance with this principle, Jewish nationality receded into the background, and the religion became its postulate. The idea of Jewish nationality required adherence to the Jewish religion, not, however, zice acrsa. Idolaters of Jewish descent ceased to be 'Jews', and Syrians, Babylonians, \&c., who accepted the Jewish religion, became at the same time 'Jews' (יהודים). The latter term lost its gentilic significance and became a rcligious designation. In post-exilic times, the pagans who lived among the Jewish people in Judea, though inhabitants of this country, were never termed 'Jehūdìm'. The truth of this definition was felt by the Rabbis, who expressed this idea in observing, 'Everybody who denies idolatry is called a Jew' (יהודי), and further assert that the

7 Isa. 56. 6, 7. This prophet went still further than Ezekiel. To him it is irrelevant whether the stranger who worshipped Jahveh lived among the Jews or in his own country. The house of God is the common property of all nations, and everybody is made welcome here. There is only this difference between Jews and Gentiles; the former are condemned for forsaking the God of their ancestors, while no blame is attached to the latter, if they refuse to join the Lord and adhere to their ancestral deities.

8 Talmud Babli Megillah I3a: כל הכופר בעבודה זרה נקרא יהודי. The Talmudic expression, however, is mislcading. A gentile denying the divinity of idols and refusing to worship them does not become thereby a 'Jew'. The Talmud of course means that every Israclite who refuses 
biblical commandment, "This is the ordinance of the passover: There shall no stranger eat thereof', exclusively refers to a Jewish idolater. ${ }^{9}$ The latter is thus, notwithstanding his Jewish descent, termed 'the son of a stranger' (בן ב נכר), according to the Rabbinic conception. The same term which is used by Ezckiel, 'Thus saith the Lord God: no stranger, uncircumcised in heart, nor uncircumcised in flesh, shall enter into my sanctuary, of any stranger that is among the children of Israel', ${ }^{10}$ may have the same meaning. We see, then, that the appellation 'Jews' (יהודים) in the exilic and post-exilic periods was a purely religious designation, ${ }^{11}$ and not a national term, like 'Nazarenes' for 'Christians' in the Middle Ages. It is of interest to notice that יהודי is the only gentilic noun from which a verbal noun, מתיהרים 'becoming Jews', is derived, but we nowhere meet with a similar derivation from other gentilic nouns,

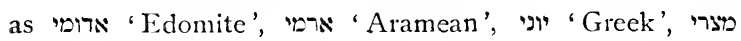
'Egyptian', \&c. The author of the Book of Esther who to recognize idols, even a descendant of any other tribe and not of Judah, is nevertheless called a 'Judean'. The same is of course true of proselytes.

- See Rashi on Exod. 12, 44.

10 Ezek. 44. 9. In the following passages the prophet excepts the Levites, though they had been idolaters. Thus the former passage seems to refer to Israelites, not to utter strangers.

11 Cassel, l.c., p. 40, is the only commentator who correctly perceived that יהורים in Esther is a distinctly religious, not a national, term. But he was wrong in believing that the name 'Isracl' remained the ideal designation characteristic of the relation of God to Israel. On the contrary, the term 'Israel' has a purely national signification, including even those who are not 'sons of the covenant' (בני ברית), according to the Rabbis, and as can be seen from the term פוּ: It is of interest to see how the modern commentators contradict themselves. They generally see in יהורים a national term (cf. Siegfried, p. I4 $_{4}$ and others', and nevertheless almost all of them entertain no doubt that the story of Esther reflects the events of the Maccabean period, though these events had a purely religious character. 
used that derivation knew that the appellation $\mathcal{F} c h i u l \bar{z}$ was a religious term. ${ }^{12}$

The words of the Babylonian Isaiah, quoted above, indicate that the promoters of the religious movement did not content themselves with the conversion of their own brethren, but became aggressive, and carried their religious ideas into the camps of the Gentiles. The religious propaganda, carried on successfully, produced the same change of conception concerning the term 'Jews' among Gentiles as among the Jews themselves. Secing people of nonJewish descent embracing the Jewish religion, the Gentiles used the term 'Jews' in a religious sense. This neither implied that an adherent of the Jewish religion was of foreign descent, nor that the family of such a one belonged to the same creed, which was an individual belief, regardless of family, race, and country.

What reason may we advance for the great success of that religious revival among the Judean exiles? Did the latter attribute their great miseries, the loss of their country and of their freedom, to their evil conduct and transgressions against the God of their ancestors? This may have been the case with a small fraction of the exiles. But if we should judge the reasoning of the average of the Judeans by the behaviour of their brethren in Egypt, ${ }^{13}$ we would be forced to the conclusion that the sufferings they experienced produced just the opposite effect, inducing them to believe that their misfortune was due to the wrath of the gods whose worship they neglected. ${ }^{1+}$ Shall we

12 For the author's statement that many embraced Judaism, see the discussion of that subject in chapter $\mathrm{IX}$.

13 Jer. 44. 16-19.

14 Ed. Meyer (G. A., III, p. 177) assumes that the Babylonian Jew' 
ascribe that success to the eloquence of the exilic prophets, and the lofty ideas of religion and morality they proclaimed? In their former country the Judeans had prophets whose eloquence and religious ideas were by no means inferior to those of the captivity, and yet they were not persuaded by their arguments and exhortations. ${ }^{15}$

The average man hardly ever judges religious creeds on their own merits, but by the conduct and deeds of their adherents. In their actions and behaviour he sees the

thought differently from their own brethren in Egypt. This is correct, as we shall further see. But he ought to have been more explicit and inform us of the reason why they did think differently.

15 This question is hardly touched upon by Ed. Meyer, l.c. He sees in the exiled Jews strict adherents to the Jahvistic religion, with the exception of a few who were soon lost among the gentiles, and does not give credence to the accusation of Ezekiel that they were idolaters, considering chapters XIV and XX mere fiction. This historical conception is decidedly erroneous. There is no denying the fact that the Jews who remained in Judca continued to be idolaters, notwithstanding the introduction of the I.aw by Josiah. For this fact we have the testimony of the eye-witness Jeremiah $(19,25,32,33$, \&c.). Those who were carried into captivity could not have been different from those who were left behind. Nebuchadnezzar did not select religious Jews as captives. Those who were carried away belonged to the partisans of Egypt, and there is no reason why they should have been more religious than the others. As to the chapters dealing with the idolatry of the Jews being fictitious, such an assertion is rather daring. The prophets frequently made predictions which did not come true. But none of them would have dared to make accusations which were not true. Ezekiel wrote his book for his contemporaries, not for modern historians. If he had accused them of sins they did not commit, the prophet would have lost his reputation for veracity and discredited all his prophecies. Ed. Meyer seems to have overlooked to whom the prophet addressed himself in those chapters, not to the common people, but to 'the Elders of Israel'. Most of the common people abandoned idols not long after their arrival at Babylon, but not the wealthy elasses, as we shall see further on. Renan (IIistory of the People of Israel, VII, I) does not explain how the anavin, 'the pietists, the fanaties', became prominent in Israel. Nor does Graetz, in his History, I, p. 332, though his description of the exiles is partly correct. 
influence of their religions. Therefore, just and benevolent intercourse of members of a religious creed with their fellow-men will help more towards disseminating their belief than the highest code of ethics. On the other hand, unfair and malicious dealings of members of any creed will do more towards discrediting the latter than the worst ethical conceptions. A people, as a rule, is favourably inclined towards the religion of its friends, and is easily persuaded to follow their example, but detests that of its enemies, without investigating which of the two religions is of higher quality. This may be the reason why the Israelites, during the period of the Judges, were willing to imitate the idolatrous worship of their friendly neighbours, but always turned back to the God of their ancestors when oppressed by them. ${ }^{16}$ This repentance may have been a purely psychological process, and not the effect of religious convictions. The modern scholars who contend that the Mosaic Code contains numerous Babylonian rites and myths, taken over in the exilic period, leave out of consideration the character of the Jews. The latter have been living among Christian nations for the last sixteen hundred years. And yet we do not find any rite or custom the Jews adopted from their Christian neighbours during this long period. This remarkable phenomenon is by no means due to the rigidity of the Jewish religion. In modern times, in liberal countries, where Jews are treated more or less fairly, many have abandoned ritual laws of the Bible and Talmud, and have even adopted Christian customs. The Spanish Jewish preachers, six hundred years ago, who considered the stories of Genesis pure mythology, and saw in the Patriarchs and the Twelve Tribes personifications 
of the planets and the signs of the Zodiac, ${ }^{17}$ were quite capable of changing the Jewish religion in the most radical manner, but for the persecutions the Christians continually inflicted upon the Jews. In paraphrasing a Talmudic saying, we may venture the paradoxical statement: The Christians did more for the preservation of the Jewish religion by their persecutions, than did the Prophets and the Talmudic literature. ${ }^{18}$ The same, of course, holds true of the Mohammedans. The Bible undoubtedly contains many ideas similar to or identical with those of the Babylonians. If they originated in Babylonia, they must have been transmitted to the Jews in a very early period, ${ }^{13}$ not at a time when the Jews suffered under the heavy yoke of that empire. ${ }^{20}$

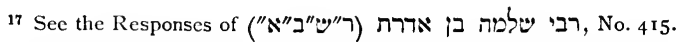

18 The Talmud observes: "The seal-ring which Ahasuerus gave to Ilaman effected a greater success than the forty-eight prophets who rose in Israel : it did what none of them was able to do, to cause them to repent of their sins', Megillah I 2 b.

${ }^{19}$ In the present writer's opinion, the transmission to Israel of ideas developed in the Euphrates Valley dates back to a pre-Mosaic period (cf. Jearish Quartcrly Review. New Series, vol. I, pp. I47 ff.). Of the same opinion is also Jastrow, in his recent work, Hebrew and Babylonian Traditions, New York, i9ı4, p 4. Albert T. Clay takes a different position, in his work Amumu, Philadelphia, I909, and contends that the Babylonian religious conceptions developed mainly in the Westland, the home of Israel.

${ }^{20}$ Renan (Ilistory, VI, I) remarks: 'It is our opinion that the pious Jews who were captives in Babylonia wilfully closed their eyes to all that surrounded them, like Bretons transplanted to Paris who will not look at anything and depreciate all that passes under their eyes.' The analogy is rather incorrect. Paris did not destroy Bretagne, and thus the Bretons have no reason to detest the former city, and merely look down contemptuously upon this state of luxury. The Judeans, however, had ample reason to abominate Babylonia, even thcse who were not pious. Jastrow, in the work cited above (see preceding note), correctly observes that the Hebrews were in no mood to assimilate ideas from those who appeared to them in the light of ruthless destroyers. 
The Judeans led into captivity to Babylonia naturally hated intensely the people which had deprived them of their liberty. Their conqueror, Nebuchadnezzar, was by no means a cruel monarch. He was a generous robber, and had no desire to destroy his victims utterly. Though depriving the exiles of their possessions and their freedom, he gave them means of subsistence in his native land. The prophets Jeremiah and Ezekiel, seeing in this king the instrument of Jahveh's judgement, were grateful to him for his gentle treatment of the exiles, and even represented him as the 'servant of Jahveh'. But the victims themselves thought differently on this point. Little did they care whether he was an instrument in the hand of Jahveh for the execution of his judgement. They saw in him only the merciless destroyer of their happiness, and thus detested and cursed this king, his country, his people, and all their institutions.

The exiles were addicted to idolatrous practices in their own country. Their local gods having, according to the common conceptions, ${ }^{21}$ no power outside of their own

21 Such a conception was generally shared by Jews and Gentiles alike. David complained to Saul: "They have driven me out this day from abiding in the inheritanee of the Lord, saying: Go, serve other gods' (1 Sam. 26. 19). The colonists transplanted by the Assyrians to Palestine found that their own gods were powerless to protect them against the lions, until they placed themselves under the protection of Jahveh, and only then were able to worslip their ancestral gods, who beeame now the manifestations and ministers of Jahveh, 'they ftared the Lord and served their own gods' (2 Kings 17. 25-33). The Assyrians frequently carried their captives and their gods to Assyria, for the purpose of depriving the latter of their power to avenge the harm done to their votaries. In Assyi the foreign gods became subjeet to the will of the indigenous gods, and had to punish their own votaries if they were not faithful to their masters. The Bible expresses the same idea: "The Lord shall bring thee... unto a nation which neitlucr thou nor thy fatler have known; and there shalt thou serve other gods, wood and stone' (Dcut. 28. 36). Jahveh, laving no representation, could 
dominions, were of no use to them in a foreign country. The same conception prevailed even among those who were worshippers of Jahveh, that $\mathrm{He}$ was powerless to assist His votaries outside of Palestine. Now the Baalim and Astartes they had worshipped were essentially and by origin identical with many gods of the Euphrates valley, and the exiles could easily have substituted the latter for the former deities. And even the worship of Jahveh could have been preserved on this foreign soil by identifying him with one of the chief Babylonian divinities of West Semitic origin, like Adad or Marduk. But how could they be expected to recognize the very gods to whom their mortal enemies attributed the victory over them? It was quite natural that the captives who could not reconcile themselves to the new conditions, and deeply felt the misery of the captivity, detested and refused to worship the gods of their conquerors. ${ }^{22}$ Not being able to preserve their old religious practices, and not willing to put themselves under the protection of the gods of their enemies, the captives were practically without any religion. There was a void in their heart, and they felt themselves forsaken by god and man.

Under those circumstances, the prophets found it easy to disseminate the old religion of Israel, as the soil was well prepared. The religion whose laws awakened memories

not be carried into captivity, and his worshippers would have to serve there other gods. It was due to the prophetic idea of the Omnipresence of Jahveh that the Jewish belief lost its local character, and could be established everywhere. Nevertheless, the idea of Galuth ha-Shekinah, that the Lord abides with his people in the captivity and is powerless to redeem them, has still survived in the Talmudic and Cabbalistic literature. It would lead us too far to dwell upon it.

22 Renar, l.c., failed to see that the idolatrous Jews had more reason to detest Babylonia than those who were pious. The latter may have seen in their miseries the hand of the Lord, while the former did not. 
and aspirations immensely dear to their hearts was enthusiastically accepted by the people. The change in their religious conceptions was effected in a short time. Not long after the first exile Jeremiah could already contrast the religious conduct of the Babylonian exiles with that of those who were left behind in Judea, in the parable of the 'two baskets of figs'. ${ }^{23}$ The Judeans in the old country still continued the practice of idolatry. But as soon as they came to Babylonia, after the complete destruction of Judea, most of them imitated the example of their fellow captives and accepted the religion of Jahveh. They had even more cause for detesting the Babylonians and their deities than the first exiles. ${ }^{24}$

The condition of the Jews who migrated to Egypt was different from that of the Babylonian captives. Egypt had done no harm to Judea. Though the latter suffered a terrible defeat, twenty years before the destruction of the Temple, at the hands of the Egyptians at Megiddo, ${ }^{25}$ Egypt was not responsible for this calamity. It was due to the presumption and short-sightedness of the Judean government. Being assured that the king of Egypt

23 Jer. 24. 3. The same is seen from the letter sent to the captives $\left(29.1-3^{2}\right)$. But not all of them had at that time abandoned idolatry (sce n. 15$)$.

24 We may assume that the captives at the final destruction of Judea, who had proved themselves faithless to the Babylonian in their covenant with the Babylonian king, were not treated with some consideration as were those who were exiled with Jehoiachin. This may perhaps be the reason why the last chapters of Jeremiah show such a deep-rooted hatred toward Babylonia, and so strangely contrast with the sentiments of this prophet toward the Babylonian empire. Jeremiah may have learned in Egypt of the sufferings of those exiles at the hands of the Babylonians, and thus his sentiments toward them naturally changed.

${ }_{25} 2$ Kings 23. $29 ; 2$ Chron. 35. 20-24. Cf. Graetz, Hist., p. 296 f. 
had no hostile intentions against Judea, Josiah had no reason to prevent the passing of the Fgyptian army through his borderland to Syria. At the time of Judea's final destruction and conquest by Babylonia, the Egyptians were the allies of that country and made an attempt to come to its rescue. ${ }^{26}$ The Judean immigrants expected to find a safe refuge in the land of their former allies, were no doubt received in a friendly way by the Egyptians, and accordingly felt a deep gratitude towards their lind hosts. 'The Queen of Heaven', to whom the immigrants sacrificed, was an Egyptian goddess whose cult had been introduced into Judea long before the reform of Josiah. ${ }^{27}$ Thus the immigrants had not the least reason for abandoning the worship of this goddess, since they believed that her wrath for having been formerly abandoned by them was the cause of their present condition. We do not know whether at that time the Jahveh-cult was given up altogether. It is more probable that along with the worship of Jahveh the Egyptian Jews practised idolatry, as they formerly did in Judea. But after the conquest of Egypt by Cambyses, the intercourse of the Egyptian Jews with their Babylonian

26 Jer. 37. 5, 6-11.

${ }^{27}$ Graetz, Hist. I, p. 300 , asserts that the worship of the 'Queen of Heaven' was introduced after the battle of Megiddo. The improbability of such an opinion is evident, as the Jews would never have accepted voluntarily the cult of a people at whose hands they suffered a terrible defent and to whom they had to pay a heavy indemnity. Moreover, the words of the immigrants: 'But we will certainly do whatsoever goeth forth of our own mouth, to burn incense to the Queen of Heaven, as we have done, we and our fathers, our kings and princes, in the cities of Judah' (Jer. 44. I7), prove that her cult in Judah must have dated from an earlier period. The Egyptians were continually on friendly terms with Isracl and Judea and the other Western states, since the Assyrians started their conquests in the West, and the Judeans may have adopted the cult of the goddess at that period. 
brethren was not without influcnce, and many of them may have become pure worshippers of Jahveh. ${ }^{23}$

As a rule, religion plays a minor, not to say an insignificant part, in the affairs of those who live in affluence. The religious propaganda was successful among the poor and middle classes of the Judean captives. The nobles, however, who exercised a certain authority over their poor brethren, ${ }^{29}$ were soon reconciled to the exilic conditions. Having been the leaders of the people, they came in contact with the government officials, and entertained friendly relations with many Babylonians. Out of deference to the latter, and in order to keep on good terms with them, these nobles were quite willing to pay their respects to the Babylonian deities. There were others who became prosperous by commerce, and were quite contented with their present conditions in the great Babylonian metropolis, where they found more opportunities for accumulating riches than in their former agricultural country. Being satisfied with their new surroundings, they had no ill will towards the king and the people who transplanted them to Babylonia, and thus no reason for refusing to worship the gods of this country. Those Jews, though representing a small portion of the captives, were, on account of their influence, a constant menace to the religious movement. The activity of the prophets was directed against them.

${ }^{28}$ But the Elephantine Papyri (published by Sachau, Leipzig, I9II) seem to indicate that the Egyptian Jews were not pure worshippers of Jahveh in the fifth and fourth centuries B.c.e. There may, however, have been a number who accepted the religious conceptions of the Babylonian Jews, and the sanctity of the Temple of Jeb was not recognized by them.

${ }^{29}$ See Ezek. 34. There can be no doubt that these 'shepherds' were the leaders of the Jews in the captivity. Cf. Gractz, l.c., 1. 332, and Renan, l.c. VI, I. 
However, they had little regard for the prophets, and ridiculed their prophecies. ${ }^{30}$ 'The elders of Israel' frequently visited Ezekiel, but not for the purpose of listening to his teachings..$^{11}$ The prophet being respected, and enjoying the highest authority among the common people, it was a matter of policy to occasionally ask his advice, in order to give to their measures divine sanction. ${ }^{32} \mathrm{Hypo-}$ critically they asked for a divine message. But he was well acquainted with their conduct, and they could not deceive him. "What do you idolaters care for God and His messages?' was his reply. Whenever he addressed the elders of Israel he accused them of idolatry. ${ }^{33}$ To the common people, however, he spoke in a different tone, comforting them and correcting their religious conceptions. ${ }^{34}$ As long as the influential men among the captives were not won over to the religious party, the existence of the Jewish religion was precarious.

The religious propaganda could not be carried on sccretly. The publicity which it aroused could not fail to engender bad feeling among the Babylonians. Combatting and deriding idolatrous conceptions in the very centre of the Babylonian cult was nothing short of high trcason. $^{35}$ Such a movement was undoubtedly the cause

${ }^{30}$ Ezek. 2r. 5.

s1 If the elders of Isracl practised idolatry, we cannot assume that they were in earnest in visiting the prophet and listening to his admonitions.

32 A similar condition is not totally unknown at the present time, that wealthy men of influence stand at the head of communities and consult the Rabbis upon the religious work of the congregations though these leaders themselves may be totally indifferent to religion.

33 Ezek. 14, 20.

s4 Ibid. 18, 33, 34, 36, 37, 38. 25-9.

85 It is inconccivable how Renan (Iistory, VI, 1) came upon the idea 
of numerous persecutions, ${ }^{36}$ which, however, had no discouraging effect upon the zeal of the pious Jews. On the contrary, even those who had held aloof from the religious movement could not remain unaffected by the sufferings of thcir brethren. It is easy to sneer at rcligious ideas, but they assume a different aspect when one sees men willing to pay for them with their lives. However, this sympathy did not have an immediate effect. Those wealthy Jews preferred their own comfort above everything, and were not inclined to expose themselves to persecutions by abandoning idolatrous practices. They were not of the stuff of which martyrs are made.

The conquest of Babylon by Cyrus dealt a death-blow to the Babylonian religion. The superstitious belief in Bēl's power was shattered. Idolatry, though still tolerated, was no longer fashionable. The seeds of the Jewish religion now found a fruitful soil cven in the hearts of the wealthy people, who gave up idolatry and joined the Jewish community. Nevertheless they still remained indifferent members, without high regard for the obscrvances of the Jewish laws. They were the people of whom the Babylonian Isaiah said: 'They who are cating swine's

that the Babylonians at that period denied both the gods and Providence. The Babylonians were certainly at that period just as religious as ever.

36 Graetz (History, I, p. 334) states that the violent hatred of the Jews toward Babylonia was caused by Nabunaid's refusal to grant them permission to return to their own country. But the letter of Jeremiah stated that they had to remain in the captivity seventy years (29.10). The pious Jews were firm believers in the prophetic prediction, and thus did not cherish any hope of an earlier return. The indifferent Jews felt comfortable in that country, and were not eager to leave it. Even if we should see in that prediction a later interpolation, we have not the least evidence for an assumption that Nabunaid had been kindly disposed towards the captives on his accession to the throne, and later changed his mind.

II. 
flesh, and broth of abominated things is in their vessels.' $^{3 i}$

If the Jews detested the Babylonian religion as being the creed of their oppressors, it stands to reason that they loved the Persian religion as being that of their liberators. This love would have been disastrous to the establishment of the Jewish religion if the Persians had been idolaters. The mere fact that the Persian religion did not do much harm to the Jewish religious conceptions is in itself a sufficient proof that there were no great differences between the principal doctrines of both the Jewish and Persian religions.

Ahuramazda was a purely spiritual god, not represented by any image, according to the Avesta. His emblem, adopted by the Iranians from the Assyrians, ${ }^{38}$ consisting of a winged ring floating in the air with a human figure rising from the circular space, was not considered an idol. ${ }^{39}$

37 Isa. 65. 4. This accusation does not refer to those who practised idolatry. No prophet would have blamed idolaters for not observing the dietary laws. On the contrary, if the latter had observed them, the prophets would have ridiculed their conduct. The prophet in those passages describes different kinds of Jewish transgressors; some were real idolaters, sacrificing in gardens and burning incense upon altars of brick; others were superstitious, remaining among the graves and lodging in the monuments, and practised necromancy; and others finally had already abandoned all those practices, but still continued to eat swine's flesh.

38 This was the emblem of the Assyrian god Ashur (see Justi, History, p. 69, and Ed. Meyer, G.A., III, p. 123). If Zoroastrianism dates from the beginning of the sixth century, we must assume that the adopting of this emblem was pre-Zoroastrian, and that Zoroaster did not consider it an idolatrous representation.

${ }^{39}$ See Ed. Meyer, ibid. Justi, however, is of the opinion that the religion of the Achaeamenides was not identical with that of the Avesta, as the latier prohibits the representation of Ahuramazda by an image. But then he would have to go a step further and maintain that the religion of the Sassanides, the most fanatical adherents of the Zoroastrian religion, 
-The essential part of this cmblem was the winged ring and not the human figure, as this emblem was represented frequently without the latter. ${ }^{40}$ This divinity was not the supreme god of the Persians, but actually the only one. The Daêvas, the gods of the popular belief, were, according to the teaching of Zoroaster, to be regarded as spurious deities, and their priests and votaries as heretics. ${ }^{41}$ The angels, by whom Ahuramazda was surrounded, originally represented abstract ideas. ${ }^{42}$ However, at a later period, when the Zoroastrian religion became corrupt, they assumed the character of the former Daēvas. ${ }^{43}$ The power of Ahuramazda, the god of light, having continually to strive under whose rule the Avesta was compiled, was not identical with that of the Avesta either, as the Sassanides represented Ahuramazda in human shape. Thus we cannot but assume that the Persians did not look upon these figures as representations.

${ }^{40}$ Cf. George Rawlinson, Herodotus, vol. I, p. 208, n. 3. That this symbol was not regarded as an image is seen from Berossus who was no doubt well acquainted with the Persian religion, and nevertheless asserts that the Persians knew of no images of the gods before Artaxerxes II (see chapter VI).

${ }^{11}$ See K. F. Geldner's artiele 'Zoroaster' in the Enc. Brit. J. Darmesteter (Zend-Avesta, p. 59) observes that Mazdcism struggled on towards unity : the Lord (Ahura) slowly brought everything under his unquestioned supremacy, and the other gods became not only his subjerts, but his creatures. Justi, in his History, remarks: 'All these things have in Zoroastrianism an essentially different position than in the natural religion. They have given up their character as gods, and preserved only their cosmic sphere of action. They are creatures and servants of the supreme god' (p. 82).

${ }_{42}$ Cf. Geldner, l.c. Darmesteter, l.c., p. 71, observes: 'They were at first mere personifications of virtue and moral or liturgical powers; but as their lord and father ruled over the whole world, they each took by and by a part of the world under their carc.'

43 In Armenia, at least, some of the Anshaspands possessed their own sanctuaries ; cf. the article 'Armenia' (Zoroastrian) by H. M. Ananikian, in Hastings's Encyclop. of Religion and Ethics, and Ed. Meycr, G. A., Ill, p. $127 \mathrm{f}$. 
with Anra-Mainyu, the god of darkness, was seemingly • limited. Notwithstanding this conception, he was, to all intents and purposes, the only god. The conception of the power of darkness in the Zoroastrian religion corresponds to that of the spiritual enemy of mankind, the Evil One, in the Christian religion, who is feared, but not worshipped. ${ }^{44}$ The term dualism applied to the Persian religion is a misnomer. The two opposing forces of light and darkness represent the principles of good and evil. There is no good without its counterpart, evil. The latter being the destructive element in nature, it is reasonable that man should place himself under the protection of the good, constructive principle. Ahuramazda himself was originally, to a certain extent, placed above these opposing forces, as has been pointed out. ${ }^{45}$ In a later period, however, the Holy Spirit was made equivalent to him. ${ }^{46}$ This would

44 Herodotus VII, II 4 seems to contradict that assumption, as he tells us: "I have heard that Amestris, the wife of Xerxes, in her old age, buried alive seven pairs of Persian youths, sons of illustrions men, as a thanksoffering to the god who is supposed to dwell underneath the earth.' But Zoroastrianism is just as little responsible for the superstition of Amestris as Christianity for some mad witches who worshipped the devil. George Rawlinson (ibid., vol. IV, p. 8) holds as probable that Herodotus merely speaks as a Greek. In the Avesta there is no vestige of such a cult. That god Anra-mainyu, being the personification of the evil principle, was naturally unlike any other deity that cculd be propitiated by sacrifices. Justi, in his History, observes: "If the ancient writers inform us that the Persians sacrificed to Hades, we may recognize therein a feature of the Median religion of the Magians' (p. 83). The latter religion, however, was not identical with that of Ahuramazda, but represents the old Iranian belief.

${ }^{45}$ A similar opinion is expressed by Darmesteter, l.c., p. 82: "When the Magi had accounted for the existence of evil by the existence of two principles, there arose the question how there could be two principles, and a longing for unity was felt, which found its satisfaction that both are derived from the same principle.'

${ }^{46}$ Cf. Geldner's 'Zoroaster', Encycl. Brit., and Justi's IIist., p. 83. 
account for the fact that Darius, in his Bchistun Inscription, does not mention Anra-Mainyu. ${ }^{47}$ Besides, the limitation of Ahuramazda's power was held to be merely temporary, as he was bound aiter a certain period to be victorious, and destroy his enemy. ${ }^{48}$

To scholarly minds there might have been great differences between the Jewish and Persian conceptions concerning the Divine Nature. However, to the average man, Jahveh and Ahuramazda were identical in all respects but in name. ${ }^{49}$ The Persian religion having no images, no temples, and no altars, ${ }^{51}$ the Jews did not see any transgression in acknowledging Ahuramazda as God, and identifying him with Jahveh. ${ }^{51}$ We may assume that they

47 It has been contended that Darius did not know anything about Zoroaster, since he does not mention Anra-Mainyu in his Behistun inscription.

48 Geldner, l.c , and Justi, l.c., p. 83.

4. Graetz (History, I, p. 402) is certainly correct in his remark: "They contrasted that doctrine witl their own belief that the God of Israel created light and darkness, good and evil.' A similar opinion is expressed by Alfred Jeremias (The Old Testament in the Light of the Ancient East, II, p. 276): "The assumption that the prophet (Isa 45. 7, 12) combats the theology of Zarathustra, at least in its exoteric interpretation, is well founded.' He further observes (n. 2): 'The esoteric religion of Zarathustra is not dualistic in the proper sense.' Bat the contrary may be true. Zoroaster's esoteric religion was dualistic, and the prophet called attention just to this fundamental principle which the common people did not perceive. But so subtle a distinction could scarcely have made any impression upon the average Jew. Moreover, it was no easy task to convince the people that God himself was the creator of evil. The very idea of the prophet that God created the darkness evidently contrasted with the story of Creation in which the first divine act was the creation of light.

50 Herodotus I, 13I.

61 It looks as if the Persians themselves saw in Jahveh thcir own God Ahuramazda under a different name. Marquart (Fundamente, p. 49) indeed contends that 'the God of Heaven' (Ezra 7. $12,25,23$ ) is Ahuramazda. This conjecture is not without foundation. The edict of Artaxerxes, in which enormous powers are conferred upon a Jewish priest, even to impose 
did not fail, whenever there was an opportunity, to impress upon the minds of the Persian officials the close relationship of their own religion to that of the Persians, and thus justly claim special favours.

During the Babylonian period, the distinctive mark of 'Jews' (יהודים) was the rejection of idols. Under Persian rule, however, this fact ceased to be the criterion of the latter, as the true Zoroastrians did the same. Zoroastrianism having adherents everywhere throughout the Persian empire, a Jew, not caring to reveal his identity, could live among Gentiles all his lifetime without being recognized as an adherent of the Jewish religion. A strictly pious Jew could

the death penalty upon those who disobey the Jewish Law, is quite incomprehensible. The Persian rulers were very tolerant towards the creeds of their subjects. There is nothing improbable in granting the Jews permission to return to their old home, to rebuild the Temple and the walls of Jerusalem, and to live according to their own laws. But it is rather strange that a Pcrsian king should have been so solicitous about the promulgation of the Jewish Law as to impose it by force upon those who had no inclination to accept it. Hence it is no surprise to find that the authenticity of that edict is denied by Kuencn (Hist.-krit. Emleitung, I, p. 165), Kosters (Het Herstel van Israel, 1903, p. 114), Wellhausen (Israel. und jüd. Geschichte, 1914, p. 160), Th. Nöldeke (Gött. Gel. Anz., 1884, 1014), and others. Ed. Meyer (Entst. d. Jud., p. 6o f.), however, has clearly demonstrated that this document is absolutely genuine. But his explanation that Artaxerxes was superstitious, and that the promulgation of the Law had to be sanctioned by the government is very forced. There is no parallel between favours granted to the Greeks in religious matters and those granted to Ezra. A polytheistic religion does not interfere with other polytheistic creeds, while the promulgation of the Jewish Law involved the negation of other creeds. We therefore suggest that this promulgation was a matter of policy on the part of Artaxerxes. The latter looked upon the Jewish crecd as being identical with that of the Persians. He was desirous of introducing the latter belief in the Western countries in order to connect them more firmly with his empire, and he saw in the Jewish Law such a connecting link betwcen these inhabitants and the Persians. We shall deal with this subject further on in chapter VII, n. 59. 
not have done so, on account of his observance of the ritual laws. But at that period these laws had not yet been firmly rooted in the hearts of the Jewish people, and many of them may have neglected them..$^{52}$ The wealthy cared more, as we have seen, for their own comfort than for religion. Many among them, indifferent to the religious observances, in all probability pretended to be Zoroastrians, and concealed their religion. Examples of this kind of Jews we may see in Mordecai and Esther.

Mordecai was born in Babylonia, as we may conclude from the pure Babylonian name he bears. The fact that he could rise later to a high position in Persia seems to indicate that he came to Persia in his early youth, and received a Persian education. ${ }^{53}$ He was a member of one of the distinguished families which had been carried into the Babylonian captivity with the Judean king Jeconiah (=Jehoiachin). We have already observed that those noble families were soon reconciled to their fate, and were idolaters. Under Persian rule, however, idolatry having gone out of fashion, they apparently abandoned it, as evidenced by the fact that the late prophets do not accuse any Jew of idolatry. But even then they were not quite averse to the worship of the Babylonian deities, being indifferent to both the Babylonian and the Jewish religions. There can be little room for doubt that the father of Mordecai was a Jew of that type. In Babylonia a proper name compounded with the name of a deity was intimately

52 The Rabbis accuse the Jews of that period of having partaken of the feast of Ahasuerus (Megillah 12a). They correctly judged that the Jewish observances were neglected at that period.

63 According to Flavius Josephus, in his story of Esther, Mordecai moved from Babylon to Susa after Esther had been taken into the house of the king. This is of course purc fancy. 
connected with the religious belief of its bearer, as may be seen from the seal cylinders. ${ }^{54}$ The bearer of a name Nabū-nasir, 'the god Nabū protects', was a votary of the god Nabū. The name Mordecai is a hypocoristicon of a complex name compounded with the divine name Marduk. Thus the full name was undoubtedly of idolatrous character. If the Talmudic statement, 'Mordecai is identical with Bilshan', ${ }^{55}$ is based on tradition, the compounded name of Mordecai was Marduk-bél-shunu, 'Marduk is their lord'.56 Such a name could be borne only by a worshipper of the god Marduk. But that does not prove that Mordecai's father was an idolater. To ease his son's path through life, that he should not be hampered with an outlandish name which stamps one as an alien, his father gave him a pure Babylonian name. Not infrequently Jews in European countries, where biblical names are very seldom met with among Christians, consider it likewise a disadvantage for the future career of their children to be named Abraham,

54 Cf. J. Krausz, Dic Göttemamen in den Babylonischen SicgelcylinderLcgenden, M ünchen, I9 Iо, pp. I $5 \mathrm{ff}$.

55 Megillah $15 \mathrm{a}$ and Menahoth 65a. However, the Talmud had not the slightest notion of the meaning of Bilshan, and explained it as 'master

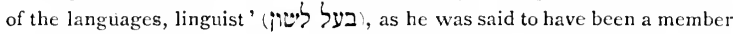
of the Sanhedrin, and was therefore supposed to understand 'seventy languages', that is to say, he had to understand the various idioms in use in Palestine, and not to have to rely upon the services of an interpreter. The explanation of Bilshan presents a counterpart to that of Mordecai, which is explained as 'pure myrrh' (פורא דכיא), the Aramaic translation of 7 is (Exod. 30. 23). The fact that the Rabbis did not know the meaning of Bilshan, and nevertheless connect it with Mordecai, seems to point to a true tradition. As a matter of faet, Bel shümu is an abbreviated name, and so is Mordceai.

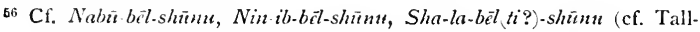
quist, Neubabylonisehes Namenbuch, Helsingfors, 1905; Assyrian Porsonal Names, 1914. Many of the numerous names Mardaka, Marduku (sce ibid.) may be hypocoristica of Maduk-beil-shunu. 
Moses, \&c. No Jew with any regard for his religion would have given his son a name that implied his being dedicated to the worship of Marduk. But Jair was not an exception in this respect. It was customary among the indifferent Babylonian Jews to name their children Arad-Gutla, Nana-nadin, Ninib-muballit, Sin-nașir, \&c., ${ }^{57}$ as may be seen from the business documents of those periods. But it may be of interest to observe that we very seldom find names of idolatrous character borne by relatives of those whose names are compounded with the divine name $\mathcal{F a w a}^{5 \mathrm{~s}}$ The latter were, as it seems, characteristic of the religious conduct of their bearers and their families as faithful worshippers of Jahveh. Mordecai was not better in this respect, if not worse, than his father, and by no means proud of his religion. Though exercising, as it seems, some authority over his humbler co-religionists in Susa, as did his distinguished family in Babylonia, he was anxious to conceal his Jewish identity, which under Zoroastrianism it was easy to accomplish, without transgressing the main tenet of the Jewish religion. The name Mordecai

57 Cf. Babyl. Exp., IX, x and Tallquist, l.c. That the bearers of such names, are Jews may be seen by the names of their fathers or sons. Renan (History, VI, I) remarks: 'A great many Jews became servants of the households of the Chaldean nobility and adopted Chaldean names, without troubling themselves about the paganism implied by these names. It did not entail any apostasy and was no more shocking than when the Jews of the Roman epoch called themselves Apollonius or Hermes.' His analogies are wrong. Strictly religious Jews never adopted in post-exilic times names implying paganism. The name Apollonius is a mere translation of the Hebrew name Samson, and the name Hermes means literally 'interpreter', and a Jew may bear such a namc, even if it is also that of a Greek god. It would be different if a Jew would be called Apollodoris or Isidorus. They would certainly be characteristic of the indifference toward the Jcwish religion on the part of thcir hearers.

58 See chapter $I X$. 
being Babylonian, we may assume that he had for special use in his dealings with Persians a pure Persian name..$^{59}$

Esther, like Mordecai, was born in Babylonia. Her name, undoubtedly identical with that of the goddess Ishtar = Astarte, is a hypocoristicon of a complex name compounded with that of this goddess. Her full name may have been Ishtar-udda-sha, 'Ishtar is her light', which would account for her two names, הדסה and, both abbreviations,

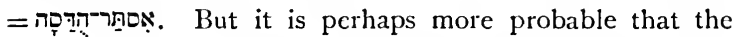
name הרסה is the Persian Hutaosa, rendered into Greek as Atossa, ${ }^{60}$ and was adopted by her in Persia. Whatever

- her compounded name may have been, the name Esther= Ishtar evidently shows that Abihail, Esther's father, was a worthy brother of Mordecai's father, Jair. Having lost both parents in her childhood, Esther was brought to Susa and adopted by Mordecai. He could not give her a better Jewish education than he himself possessed. Their real characters are shown in the second chapter of the Book of Esther.

59 We find names compounded with $u d d a$, cf. Tallquist, Namenbuch.

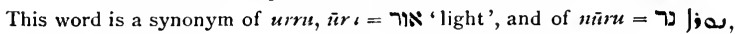
of the same meaning, and is etymologically identical with Hebrew 'splendour', which is used also in the formation of Hebrew proper names (see Hebr. Dictionary). Both synonyms are found in cuneiform proper names, as in Ilu-ur-ri, U-ru-l Ma-lik, \&c. ; Nüri-Ishtar, \&c. (see Tallquist, l. c.) That $u d$-du does not refer merely to the 'daylight'; though UD = Shamash, may be seen from the name Nabü-shakin-ud-du, 'the god Nabū makes light' (cf. ibid.). This noun may have been pronounced hud-du, according to the etymology. We see that even the Sumero-Babylonian word $c k a l$, 'great house, temple, palace' was by the Hebrews pronounced hēkäl.

${ }^{60}$ Stanley, History of the Jewish Church, III, p. 196, remarks: 'Hadassah (her Hebrew name) is either "myrtle", or else a Hebraized form of the Persian Atosst.' But the Hebrew form stands nearer to the Persian name Hutaosah than the Greek rendering Atossa. Cf. Cassel, l.c., p. 54. 
Orthodoxy and Heterodoxy, the two opposing tendencies within Judaism, are by no means peculiar to and characteristic of our enlightened era. They are as old as Judaism itself, though in each age, in accordance with the prevailing ideas, Heterodoxy assumed a different character. As long as idolatry was fashionable, the Heterodox were idolaters; in the Alexandrian age, Hellenists; under the Maccabees, Sadducees; during the Jewish-Christian era, adherents of the Christian doctrines; in the period of the Geonim, Karaites; in the Middle Ages, philosophers; and at a later period, Cabbalists. Orthodoxy, the real representative of that Judaism established during and after the Babylonian captivity, has survived all these changes. ${ }^{61}$ The same two tendencies in Judaism are met with in the times of Mordecai and Esther.

The author of our story states: 'Esther had not shewed Estler ir. her people nor her kindred; for Mordecai had charged her that she should not shew it'.62 He tells it so frankly and

61 Many of those opposed to Rabbinic Judaism, whose aim was at the start to abrogate its rigid observances, found that they could not draw a strict line between the latter and those of the Mosaic I.aw.

62 The passage לא הגירה אסתר את עמה ואת מולרתה is not quite

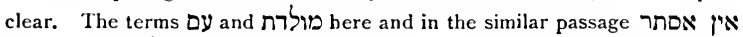
אי מגרת מולדתה ואת עמה (II, 20) might be regarded as hendiadys. But

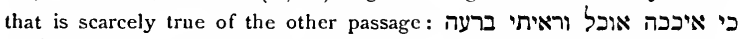

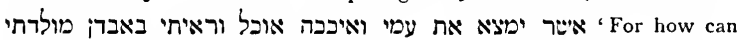
I endure to see the evil that shall come unto my people? or how can I endure to see the destruction of my kindred'? (VIII, 6). The term מולדת means either 'native place' or 'kindred'. The former meaning is here impossible, as Esther's native place was Babylonia, and the latter very improbable. But מולרת may mean also 'place of origin', and conld refer to Judea. Such an interpretation is not impossible, as the execution of Haman's edict involved the destruction of the Jewish state, as we shall further see. But it is strange that the terms עם עמולרת are nowhere found, outside of Esther, in the Old Jestament. We find only אריץ ומולדת מולת אריץ מולדת. 
naively, without giving any reason for such a conduct, as if it were the most natural way and a matter of course, and not a dastardly act, for a Jew to conceal his religion. ${ }^{63}$ It was indeed unnecessary for the author to explain why Mordecai charged Esther not to disclose her Jewish identity, as we can read the reason between the lines. Relying upon Esther's great charms, which, in his belief, could not fail to captivate the king's heart, Mordecai was apprehensive of her being excluded from the competition for the rank of queen if she was known as an adherent of the Jewish religion. For her elevation he was ready and willing to sacrifice her religion. ${ }^{64}$ If Mordecai had been imbued with

Hence there is room for doubt whether the original text contained the word מולדת. We shall find that Haman's edict was not directed against the Jewish race, but against those who were adherents of the Jewish religion. They were in no danger, if they abandoned it. But at a later period, the real issue of that event was not known any longer. The term דת, a Persian loan-word (which oceurs so often in Esther), in the passage their laws are diverse from all people', refers of course to the Jewish religion. The identical term is used in the Mishnah

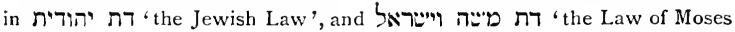
and Israel'. Hence we venture the following suggestion. The same word ד might have been contained in the original text in the passages quoted. 'But a later copyist changed the word מולדת into, believing that and עם are superfluous synonyms, as a member of the Jewish race is of course an adherent of the Jewish religion. Thus the original meaning of the passages II, 10. 20 might have been: Esther kept secret her people and her religion. In her supplication to the king, Esther complaincd not only about the evil that shall come unto her people, but also about the disappearance of the Jewish creed. Siegfried, l.c., is correct in objecting that here out of place.

63 Ibn Ezra remarks: 'Some say that Mordecai was wrong in commanding Esther not to disclose her origin, because he feared that he might not take her for a wife if he knew that she was one of the cxiles. But others say that Mordecai learned in a dream that Esther was destined to save Israel'.

51 Paton, l.c., p. I 78 , observes: "Therc is nothing of the martyr-spirit in Mordecai, as in Daniel and his friends who display their Judaism at all 
the spirit of Ezra and Nehemiah, there is no doubt that rather than giving her in marriage to a Gentile he would have slain his adopted daughter with his own hands, and he would certainly have charged her to disclose her religion. ${ }^{65}$ If Esther had been a true daughter of Israel she would have done everything in her power not to become the wife of a Gentile, preferring the observance of her religion to the rank of a queen. ${ }^{6}$ On informing the keeper of the harem of her religion, Esther would have done her duty, and been free from blame if he had kept her notwithstanding that reason, as we could not condemn her for not having been courageous enough to prefer death to that fate.

However, on the other hand, the question presents itself: Why did Mordecai so ardently desire to see Esther as queen? Was it due to his ambition? Certainly not! ${ }^{67}$ If he had been ambitious, it would have been easy for him

costs. So long as there is any advantage in hiding it, he does not let Esther tell her race; only when secrecy is no longer useful, does he bid her disclose it' (see n. 68).

${ }^{65}$ The author of the apocryphal additions to the Greek version of Esther could not comprehend either how the pious Esther could have acted in that way, and lets her say in her prayer: 'Thou hast knowledge of all things, and thou knowest that I hate the glory of the wicked and abhor the bed of the uncircumcised and of every alien'. This prayer is characteristic of the mode of thinking of religious Jews of the Graeco-Roman period concerning intermarriage.

${ }^{66}$ See, however, Cassel, p. 6r f.

67 The commentators who think that Esther concealed not only her Jewish origin, but also her kinship to Mordecai, must admit that the latter could hardly have profited anything by Esther's exalted position. Moreover, they assume that 'Mordecai was sitting in the king's gate' as a lounger, and not in an official character. Thus what advantage was there for Mordecai? Hence it is evident that Mordecai did not act out of selfish motives in furthering the elevation of Esther, but for the welfare of his people (see n. 64). 
to be appointed to a high position after the elcvation of Esther, or at least after having saved the king's life. Thus it is evident that his desire that Esther should be elevated to the rank of queen was not prompted by selfish motives. Although concealing his own religion, Mordccai was nevertheless solicitous for the welfare of his people, and was convinced that Esther on becoming queen would be in a position to render them many useful services, as indeed she was.

However so prudent and farsighted the policy of Mordecai, in his endeavour to elevate Esther, may have been for the benefit of the Jewish people; from a purely religious point of view, we either must condemn his conduct or accept utility as the solc standard of rectitude. An approval of Mordecai's action would give full licence to intermarriage. We might say that that prohibition under certain circumstances may be disregarded, if any essential advantage would accrue to the Jewish people or to some Jewish community from such an intermarriage. It would be wellnigh impossible to draw a strict line between a marriage to a king, a high official, or any other person. But Mordecai no doubt belonged to that party which espoused intermarriage between the Jews in Palestine and their non-Jewish neighbours, as by these alliances they were strengthening their own position. ${ }^{68}$ That policy, however, though of great advantage to the newly-established Jewish state, was disastrous to the Jewish religion, and wc may doubt whether the latter would have survived if such a practice would have been permitted to continue. On the

68 That party was in all other respects just as strict worshippers of Jahveh as Ezra and Nehemiah, since even the family of the High-priest was related by marriage to the Samaritan Sanballat and to other non-Judaeans. 
other hand, the zeal of Ezra and Nehemiah against intermarriage caused many hardships to the Jewish people in Judea, and jeopardized the existence of the new state, but the Jewish religion remained pure and intact. Thus Ezra and Nehemiah represented Orthodoxy, while Mordecai was the representative of the Heterodox wing of Judaism of that period which advocated intermarriage.

It is characteristic of Jews in all periods that, though indifferent to religious observances, and being hardly recognized as members of the Jewish people, at times of religious persecutions they do not stand aloof from thcir suffering brethren, but identify themselves with them in every respect, some of them becoming even more or less religious. The religious persecutions which soon broke out had the same effect upon Mordecai. Seeing the sufferings of the Jews, Mordecai openly declared his adherence to the Jewish religion, ${ }^{63}$ and did everything in his power to assist his brethren. But a change produced by sympathy, not conviction, never has a lasting effect. Mordecai, after his elevation to the rank of prime minister, was not and could not have been religious. ${ }^{70}$ The Rabbinic homiletic interpretation of the passage, "He was pleasing to most of his brethren', that it meant to indicate that a part of the Sanhedrin separated themselves from him, ${ }^{71}$ contains a great deal of truth, even morc than the rabbis intended to imply. A part of his brethren refused to have any intercourse with Mordecai. Even among the Sanhedrin, the leaders of Israel, the strictly religious Jews, who do not barter the tenets of their religion for worldly advantages,

69 See chapter VIII.

70 Cf. also Renan, History, VI, I.

${ }^{71}$ Megillah $16 \mathrm{~b}$. 
though being in atl periods Israel's very representatives and prescrvers, always form only a small fraction. And men of that type refused to associate with him.

The Book of Esther was in all probability composed in Babylonia, not Palestine, ${ }^{72}$ as the former country was for a considerable period the real centrc of Jewish learning. It undoubtedly was composed at a time when the personalitics of Mordecai and Esther were still well known. Its compilers were the Sopherim, who strictly adhered to the principles of Ezra and Nehemiah. Upon them devolved the task of commemorating an event, in which the opponents of the latter, against whose principles they still had continually to fight, figured as heroes and saviours of Israel. Those Sopherim were in a most cmbarrassing situation. They could not deny the fact that Mordecai and Esther, though having been transgressors of the Law, actually effected the rescue of Israel's religion. Not to record such an cvent would have bcen disgraceful. ${ }^{73}$ But

72 But they did not put this story in writing during the life-time of Mordecai and Esther (see following notes and chapters VII, IX).

75 Megillah 7 a : "Esther sent to the sages, saying: "Record this event of mine for future generations." But they sent back : "It is written, Have I not written for thee three times?" (Prov. 22. 20'. This passage teaches that any event should be recorded only three times, and not four times, and the memory of Amalek's destruction is already recorded three times. (Thus they refused to record it) until they found for her a biblical verse: "Write this for a memorial in a book" (Exod. I6. I4): "write this" refers to the records made by Moses himself, here and Deuteronomy 25. 17-19; "for a memorial" refers to that which is written in the historical records of the prophets (I Sam. I5. I-34): "in a book" refers to the event of Purim, the story of which ought to be represented in a special Book'

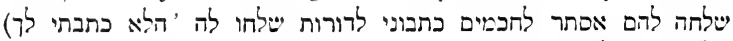

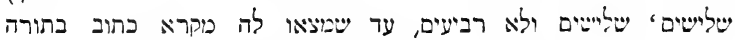

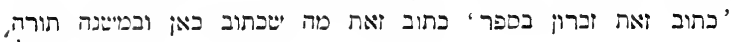

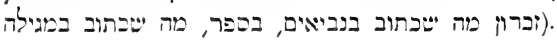


it could not be done without jeopardizing the religious principles for which they stood. To describe Mordecai and Esther as ardent adherents of the Jewish religion was impossible. The religious conduct of Mordecai and Esther was well known. Besides, the Sopherim would under no circumstances have consciously distorted the facts. To represent, however, non-religious Jews as God's chosen instruments for the preservation of Israel, would have becn destructive to the ritual edifice they strove to preserve intact. The people would have been perplexed, and would have raised the question: How could the rites and observances be an essential part of the Law of Israel if God chose for his own instruments people who did not care for them? The only way out of this dilemma was to represcnt the events exactly as they happened, without suggesting that there was any divine intervention. In this way the compilers did not commit themselves, and the people could interpret this story each according to his own sentiments. In the present writer's opinion, a strictly orthodox rabbi of to-day would be in the same predicament, if compelled by circumstances to write the biography of a great Jewish philanthropist who was indifferent to all religious observances, and would have to act in the same way as the Sopherim did in the compilation of the Book of Esther, circumspectly avoiding all matters pertaining to religion.

There is a Talmudic statement that Esther requested the sages of her period to compile the story of that event, and they at first refused to comply with her request. ${ }^{74}$

74 Rabbi Joshua, son of Hananiah (flourished about roo c. E.), still held that this Book ought not to have been put in writing, in explaining: 'write this' refers to what is written in Exodus; 'for a memorial' refers to the repetition of that commandment in Deuteronomy to remind Israel to keep it in their memory; 'in a book' refers to what is written in the Jook of I1. 
Who knows whether this narrative is not based on some tradition? We can well imagine that it was Esther's just ambition to have the event in which she played such a conspicuous part recorded for the admiration of future gencrations, and that the Sopherim, confronted by the difficulty of such a task, used some subterfuge to be excused from compiling that story, in expressing their opinion that it ought to be handed down by tradition, like the Oral Law, and not to be recorded. ${ }^{75}$ We may even assume that they definitely refused to undertake this compilation, and that the only record of that event consisted of the letters scrit out by Mordecai and Esther. ${ }^{76}$ Later, however, being afraid lest the Feast of Purim might assume a non-Jewish character, as we shall sec further on, the Sopherim could not but compile the story of that event, and order its

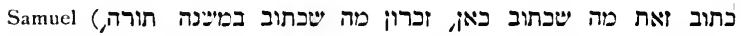
בספר מה שכתוב בנביאים homiletic explanations do not give the real reasons pro and contra. The Rabbis were averse to questioning the religious conduct of Mordecai, and therefore expressed their opinions in homiletic disguise.

76 See chapter IV.

76 We shall see that the Sopherim were even averse to the commemoration of this event, because the time of the celebration was simultaneous with that of a Persian festival. The Talmud indeed tells us: 'Esther sent to the sages : "Establish for me a festival for future generations". But they sent back: "Will you incite envy against us among the nations?" She, however, sent back: "(There is no fear of that) as the event of mine is already written in the book of the chronicles of the kings of Mledia and

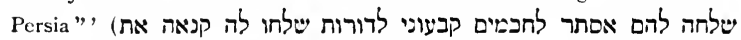

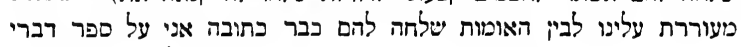
הימים למלכי מרי ופרס perhaps see a trace of a tradition that the Sopherim refused to sanction the establishment of the festival of Purim. We observe, by the way, that this saying seems to confirm the suggestion in chapter IV, that the existence of the Book of Esther may have caused trouble to the Jews in the East in a certain period, 'inciting envy against them among the nations'. 
reading on the day of this Festival. Both Rabbi Joshua and Samuel in decreeing that 'the Book of Esther does not defile the hands ${ }^{\prime}, 77$ were undoubtedly displeased with the non-religious style of the book, and considered such a defect just as bad as the scepticism of Ecclesiastes. ${ }^{78}$ Looking upon Mordecai and Esther as saints in Israel, and on the compilers of that book as having been inspired by the Holy Spirit, the non-religious character of that book was beyond their comprehension. They may have believed that the Sopherim did not dare to represent Ahasuerus as an instrument of the God of Israel, and therefore omitted all religious elements. Those rabbis, however, did not approve of such a procedure. In their opinion, if a book that records such a signal rescue of Israel had to be devoid of all religious elements, the records of that event ought not to have been put in writing, but handed down by tradition. ${ }^{79}$ This is the real meaning of the Talmudic interpretation of those rabbis' opinions: 'The story of Esther

77 The saying אסתר אינו מטמא את הידים 'the Book of Esther does not defile the hands', is mentioned only in the name of Samuel, not in that of Rabbi Joshua. Since, however, we are informed that 'Samuel holds the opinion of Rabbi Joshua', that Esther ought not to have been recorded, we must assume that in the latter's opinion, Esther does not belong to the sacred Books, and thus does not defile the hands (see ibid.).

${ }^{78}$ As to Ecclesiastes, there are divergent opinions: 'Rabbi Meir says : 'Eeclesiastes does not defile the hands, but there is disagreement concerning Canticles'; Rabbi Jose says: 'Canticles defiles the hands, but there is disagreement concerning Ecclesiastes'; Rabbi Simeon says: 'Ecclesiastes belongs to the decisions in which the School of Shamai was more lenient than the School of Hillel, but Ruth, Canticles, and Esther defile the hands' רבי מאיר אומר קהלת אינו מטבא את הידים ומחלוקת בשיר השירירים,

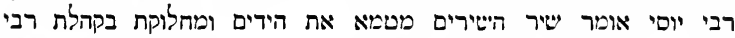

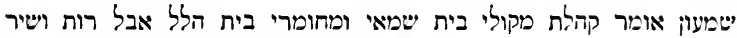

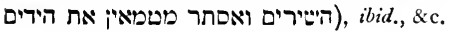

79 See note 73. 
was composed to be read, but not to be written down'.80 The latter agreed with their colleagues that 'the compilation of the story of Esther was made by the inspiration of the Holy Spirit," 81 but were unwilling to admit that the Holy Spirit had inspired them to omit the name of God, seeing in this omission a certain faint-heartedness. The other rabbis, however, looked upon it from a different point of view, holding perhaps that the story is the more religious in its spirit, because of its being so entirely free from the phraseology of religion. ${ }^{82}$

Bearing in mind the religious conceptions of Mordecai and Esther, we understand why Sirach did not enumerate them among 'the Fathers. of the world' ${ }^{83}$ To any un-

80 אסתר נאמרה לקרות ולא נאמרה לכתוב, Megillah 7 a.

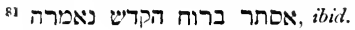

82 See also Stanley, History, III, p. 201.

${ }_{83}$ Wildeboer, p. $\mathbf{1 7 2}^{2}$, and other commentators conclude from the fact that Sirach did not mention Mordecai and Esther, that their story was unknown in his time. Jampel, however, calls attention to Sirach's omission of Daniel and Ezra. But these omissions do not invalidate the critics' objection. The existence of the historical Daniel cannot be denied, as we have for it the testimony of Ezekiel (28. 3): 'Behold, thou art wiser than Daniel'. But there can be no doubt that the latter was not a contemporary of Ezekiel, as he is represented with Noah and Job as an example of a Godfearing man ( I $_{4} \mathrm{I}_{4}, 20$ ). If he was not a pre-historic personality, he must have lived in the hoary antiquity. The Book that bears his name is no doubt younger than Sirach. As to Ezra, Sirach was not a 'Bible-critic'. In his eyes Ezra was merely the copyist of the Mosaic Law and a holy man, but no more holy than the prophets Haggai, Zachariah, and Malachi, whom he also omitted to mention. Ezra, in Sirach's opinion, was only the leader of about fourteen hundred immigrants and one of the great teachers of the people. But having built neither the Temple nor the walls of Jerusalem, he did not leave a lasting memorial for future generations. Of Nehemiah he could say that he raised the walls of Jerusalem and restored the home of Israel. But Sirach could not have omitted the names of Mordecai and Esther who played such an important part in Jewish history, if he had considered them saints in Israel. 
prejudiced mind it must have been obvious that they did not belong in this assemblage. In a later period, however, the Book of Esther having become popular, it would have been blasphemy to criticize the conduct of these saviours of Israel. The rabbis had no other course but to represent them as Jewish saints, and endeavoured to the best of their ability to defend and justify all their actions. 


\section{CHAPTER VI}

The nature of the danger recorded in the Book of Esther-The introduction of anthropomorphic images into the Zoroastrian religion - The reform against Zoroastrianism-Religion and state-Zoroastrianism as the supreme religion of the Persian empire-Anahita as the representative and manifestation of Ahuramazda-The effect of the reform-A Persian tradition - The reform affected the Jews - The religious persecutions-The strictly religious Jews-The festivals of Anahita-Historical reminiscences of the persecutions.

IN the preceding chapter we have discussed the term 'Jews' (יהורים), and found that it designates adherents of the Jewish religion, regardless of their extraction. This definition is borne out by historical facts. All dangers and persecutions the Jews experienced, from the time of Antiochus Epiphanes down to the present, were solely due to their religion, and not to their race extraction. Jews never suffered, as we already observed, if they conformed to the religion of the country where they dwelt, because such a step wiped out the mark that distinguished and separated them from the Gentiles. Jews living in a country for many hundreds of years were always considered aliens. But if one among them abandoned his religion he became at once a full-fledged citizen.

The danger impending over the Jews recorded in the Book of Esther was no exception in that respect. This also had a purcly religious character. The current opinion 
concerning the personality of Haman and his detestation of the Jewish race is absolutely erroneous. If a man is an inveterate enemy and a zealous persecutor of a certain religious creed, which he regards as pernicious to the welfare of his country, it does not follow that he is a wicked character. Haman was not worse than many Christian and Mohammedan potentates who, actuated by zeal for their own religions or by political reasons, fanatically persecuted their Jewish subjects, but who in other respects by no means showed vile dispositions. Haman never thought of destroying a whole race without cause on their part. His decree was not aimed at the Jewish people, but at the Jewish religion, and such a danger could be easily averted by renouncing it. His intention was the destruction of an idea, not of the individual who adhered to it. The fate of being exterminated was of course inevitable, if the Jewish people should remain stubborn and refuse to part with their religious belief. But the decree was of no effect if they ceased to be 'Jews' (יהודים). However, that religious persecution was not due to his personal aversion to the Jewish religion. It was dictated by the policy of the Persian empire, with which the Jewish religious conceptions came into collision.

Under the reign of Artaxerxes II an important innovation was introduced into the Persian religion. The Babylonian priest and historian Berosus informs us that the Persians knew of no images of gods until Artaxerxes II erected images of the goddess Anahita in all the centres of the Persian empire. ${ }^{1}$ The statement of Berosus is confirmed by the cunciform inscriptions. ${ }^{2}$ Those of the former

1 Müller's Fragmenta Historicorum Graeconum, 16.

${ }^{2}$ Die Altpersischen Ke'linschriflen (Weissbach und Bang), p. 45. 
kings name only Ahuramazda, but Artaxerxes II, in his inscriptions, invokes Ahuramazda, Anahita, and Mithra. The last two gods belonged to the old popular belief, but were abandoned by the true Zoroastrians. ${ }^{3}$

This innovation, having been against the spirit of Zoroastrianism, could not have met with the unanimous approval of the Persians. Now Zoroaster's religion could have been preserved in purity only within a limited circle. - The common people required religious food of a more sensual and vigorous character', as Ed. Meyer observes. ${ }^{4}$ Nevertheless, that limited circle was no doubt sufficiently numerous and influential to resent and oppose such an innovation. The erection of sanctuaries for Anahita in all the centres of the Persian dominion, even among nonIranians as in Sardes and Damascus, indicates that Artaxerxes II desired to introduce the worship of this Iranian goddess throughout his empire. What may have caused Artaxerxes II to depart from the ways of his predecessors? It could not have been a mere fancy for overthrowing the old established principles of the Zoroastrian religion. Some important object must have been involved whose attainment he deemed necessary for the consolidation of his empire.

Religion was always intimately connected with the worldly power. All the institutions of the government were permeated by religious ideas. ${ }^{5}$ The king was merely the representative of the tutelary deity of the state. Accordingly the rank of the deity depended upon that

${ }^{3}$ Cf. Ed. Meyer's article 'Artaxcrxes', Encycl. Brit. and G. A., III, 127.

4 lbid., p. 126.

"On this subject sec especially Jastruw's Religions. Aspects and Lelicfs in Beliglonia and sosviel, 1911, chapter V'. 
of the king by whom it was represented, rising and falling with the fortunes of its representative. In one case, however, the deity assumed such a high position that it became the protector of the state which had raised it from obscurity, and its rank remained independent of that of its representative. Such was the case of the Babylonian god Marduk who was originally an insignificant local god of Babylon. But he became the head of the Babylonian pantheon, and was identified with the former Sumerian chief god, Enlil of Nippur, because Babylon had become, under the reign of Hammurabi, the capital of the Babylonian empire. This city, though politically no more of importance, after the passing of the Hammurabi dynasty, nevertheless retained its high position as the seat of Bël-Marduk. The king who scized the hand of the god on the New Year festival considered himself the greatest monarch, and claimed by virtue of his position the rule of the world. The various Babylonian cities were united by a religious idea.

The constitutions of the governments of the Euphrates Valley present in that respect no exception to the general rule. The same fundamental idea of the body politic existed in most ancient states. Religion was in antiquity the basis of the political community. The state existcd only through the gods. In claiming to fight for the glory of the gods and not for its own aggrandizement, the state could hold its own against other powers, and increased thereby in strength and prosperity. ${ }^{6}$ The theocratic constitution of Israel, as ordained by its Lawgiver, though never fully rcalized, was no novelty. The institutions of ancient Grecce, as the Amphictyonic Council and the

$$
{ }^{5} \text { See Ed. Meyer, G. A., III, p. } 167 .
$$


Olympics, which were of paramount importance for the unification of the various Greek states and the preservation of their independence in the Persian Wars, were of purely religious origin. The mighty empire of the Caliphs was founded upon Islam. The mediaeval Christian rulers pursued the same policy. Thus religion was in all periods considered the best cement for joining heterogeneous races into one united nation.

However, the Persian empire was different from other governments of antiquity. Here we do not find that intimate relationship between Temple and Palace. Although the Achaemenian kings had been the very representatives of the Zoroastrian religion and identified with all its movements, ${ }^{7}$ the Persian empire was not founded upon a religious idea. The conglomerate of the heterogeneous elements of which it consisted was kept together by force of arms, the effect of which could only be transitory. The Persian rulers felt themselves powerful enough to hold the conquered countries in obedience without the aid of religion. As a rule, they did not interfere with the creeds of their subjects, and made no attempts to disseminate their own religion in their dependencies. On the contrary, though considering the polytheistic religions, in which the gods were represented in human and animal shapes, puerile, the Persian kings treated them with all reverence. We must, of course, except the conduct of the demented Cambyses in Egypt.

When Artaxerxes II ascended the throne, the authority of the empire in the interior provinces was badly shaken. Insurrections frequently occurred, and the disintegration

7 See Jackson, Zoroaster, 'On the Date of Zuroaster'. 
of the empire seemed imminent. Though its foreign relations were better than before his accession, this was not due to its power, but to the discord of the Grecian states. According to Plutarch: 'The Greeks who forced their way, as it were, out of the very palace of Artaxerxes, showed that the grandeur of the Persians was mere parade and ostentation'. The liberal policy pursued by the Persian kings, which at the time of their vigour largely contributed to the building up of the empire, as the subjugated countries soon became reconciled to its rule, " was now, as the Persians were becoming somewhat enervated, the very source of its wcakness. ${ }^{10}$ The Persian empire lacked an idea suitable to cement the divergent races into one united nation.

We may safely assume that the Persian patriots and the king's councillors were fully aware of the gradual decay of the empire, and devised various remedics to check its progress. One of the councillors, acquainted with Oriental history, and thus knowing how religious ideas were utilized for political purposes, and what powerful instruments they are for the consolidation of governments, suggested the religious idea as the best remedy for the unification of the empire: religion should form the link between king and subjects. If Zoroastrianism, of which the king was the visible representative, should be proclaimed as the

8 Plutarch, Artaxerxes, XX. I.

9 Ed. Meyer, G. A., I11, p. 94.

10 We have a somewhat analogous case in the Turkish empire. At the height of their power, the Turks were rather tolerant towards their subjects and did not impose upon them their religion and language. Owing to this policy, the subject nations were soon rcconciled to their rule. If they had not been tolerant, the European Christian nations would have united themselves against them, and we may doubt whether they would have prevaled over a united Europc. But at present the policy that was formerly the source of their success, is the very cause of their downfall. 
supreme religion of the empire, all the subjects being enjoined to accept it, the authority of the king, on account of its religious charactcr, would be respccted everywhere, and the common cause of religion would ensure the loyalty of the subjects.

However, that plan was not feasible without fundamentally modifying the doctrines of the Zoroastrian religion, which, as we have seen, was purely spiritual, without images, temples, and altars. The acceptance of the principles of this religion, which forbade the worship of idols and rejected all other divine beings beside Ahuramazda as spurious deities, was incompatible with the continuation of all other polytheistic religions throughout the Persian empire. The introduction of such a religion could not be made compulsory without simultaneously oppressing all other idolatrous creeds. Such a measure would undoubtedly have been the cause of a general uprising among the polytheistic subjects, and unfailingly would have caused the downfall of the Persian empire. The people, accustomed from immemorial times to the worship of visible gods, were incapable of comprehending a religion without physical representations. This religion could not appeal to the people, even if it should modify its monothcistic principle, and grant to them the permission to continue the worship of their own deities as manifestations of the supreme god Ahuramazda. There was indeed the winged circle, which the Zoroastrians were able to admit as a religious emblem without sacrificing any principlc. ${ }^{11}$ But no temple was ever erected to Ahuramazla, as Ed. Meyer points out, ${ }^{12}$ eren after the 
Zoroastrian religion became corrupt. The Zoroastrians seemed to have held and strictly adhered to the principle that the God of heaven and earth could not be worshipped in the limited space of a house. ${ }^{13}$ Besides, the simple worship of this god, consisting in keeping up the Holy Fire, had nothing alluring and attractive for the people. Yet the Zoroastrian religion could not be made popular without images, temples, and altars.

The Daēvas, the gods of the old Iranian religion, which Zoroaster declared to be spurious deities, were at a later period, but already in the time of Herodotus, ${ }^{14}$ introduced into the Zoroastrian religion, though not yet represented by images. The highest among these Daēvas were Anahita and Mithra, equivalent to the deities Ishtar and Shamasti in the Babylonian pantheon. Anahita, and as Marquart contends, ${ }^{15}$ in conjunction with Mithra, were, under the

13 The same idea is expressed also by the exilic Isaiah: "The heaven is my throne, and the earth is my footstool ; where is the house that ye built unto me? and where is the place of my rest?' (66. r), and also in the prayer of Solomon: 'Behold, the heaven and the heaven of heavens cannot contain thee; how much less the house that 1 have builded' (I Kings 8. 27). We need not see in this idea Persian influence or vice versa, as it is simple enough to originate among various people independently. We shall further refer to the fact that the Babylonian supreme god Anu does not seem to have ever possessed a centre of his own, and it may be due to the same idea.

${ }^{14}$ See Herodotus 1, 131, where he states that the Persians believed in elementary gods, which is certainly not in accordance with Zoroaster's doctrines.

${ }_{15}$ Fundamente, p. 37. It is noteworthy that Plutarch, Artaxerxes, XXIII, 7, states that Artaxerxes paid homage to no other goddess but Hera. This goddess is evidently identical with Anahita, though the latter is identified by him wilh Artemis, XII, 4. We need not assume that he contradicts himself. Anahita has been identified with the Babylonian goddess Ishtar who appears in various manifestations; as Bëlit iläin, 'Mistress of the gods', she corresponds to Hera; as daughter of $A \mathrm{nu}$, to Pallas Athene; as goddess of vegetation, to Demeter and also Perseplone; 
reign of Artaxerxcs II, selected to be represented as manifestations of Ahuramazda. Anahita was originally a goddess of vegetation, but later became goddess of fertility, and was represented with all the attributes of Ishtar. The main feature of her cult was prostitution. ${ }^{16}$ A divinity of this kind strongly appealed to the sensual propensities of the people, and was readily accepted everywhere by the polytheistic inhabitants of the Persian empire as chief deity and representative of the supreme god Ahuramazda. If Marquart's view, which seems to be corroborated by the cuneiform inscriptions of Artaxerxes, is correct, we may assume that the Mithra-Feast became about the same time the chief Persian festival, in which the king used to get drunk and performed the national dance of the Persians.

The introduction of that new element into the Zoroastrian religion was not due to the predilection of the king for Anahita. This was done as a political measure for the consolidation of the empire. Hence it was not left to the free will of the people whether they should imitate the example set by the king. The worship of that goddess was made compulsory. The supremacy of Anahita actually meant the supremacy of the ruling race. Her worship was made a test of loyalty. Those who refused to recognize her were marked as disloyal subjects. Marquart is unquestionably right in seeing in the erection of the images

as sister of the Sun-god, to Artemis; as goddess of fertility, to Aphrodite. All these attributes may have been taken over by Anahita. Plutarch may have not known it, and speaking from a Greek religious point of view, differentiates between Anahita of Susa who may have been worshipped as Hera, and between $A$ nahita of F.cbatana who may have been identified with Artemis.

${ }^{16}$ See Justi, History, p. 95, and Ed. Meyer, G. A., III, p. $126 \mathrm{f}$. 
of that goddess in all the provincial capitals of the Persian empire a royal law enjoining on all the inhabitants the worship of Anahita. ${ }^{17}$

Did that reform of the Zoroastrian religion produce the desired effect of more firmly uniting the various races of the Persian empire? This may or may not have been the case. We know only that it did not prevent that empire's final downfall. But we may reasonably doubt whether even united and in their full vigour the Persians could have prevailed against the military genius of their conqueror. However, that innovation was of paramount importance for the dissemination of the Zoroastian religion. We may assume that the successful introduction of the latter, and in its wake of the Persian language, among the Turanians in Armenia and Cappadocia ${ }^{18}$ was chiefly due to this reform of Artaxerxes II. In Armenia, Anahita had temples at Artaxata and Yashtishat in Tauranitis, and especially in Erez in Akilisene, the whole region of which was consecrated to her. ${ }^{19}$ Here she had a golden statue, and Strabo states that the daughters of the noble families used to go there and prostitute themselves to strangers before their marriage. ${ }^{20}$ She was worshipped likewise in Pontus and Cilicia. ${ }^{21}$ In Lydia she left numerous traces of her presence, and became amalgamated with Cybele. ${ }^{22}$ The Zoroastrian religion, which even among the Iranians could be kept in purity only in a limited circle, could hardly

17 Fundamente, p. 37.

18 See ibid., p. 38 , and especially the article ' $\Lambda$ rmenia (Zoroastrian)' in Hastings' Encyclup.

19 See the article 'Anaitis', ibid.

20 Strabo's Geography, XI, I4, $16 . \quad{ }^{21}$ Ibid., XI, 8 ; XII, 3.

22 See Rev. Archeol, 3rd Series, VI, 107 ; VII, 156. 
have gained adherents outside of Iran without undergoing a complete change. Formerly there was a gulf between the popular religion and that of Zoroaster, as the common people, though Zoroastrians, by no means abandoned the old Iranian Daēvas. ${ }^{23}$ This gulf was now being bridged over by the innovation of Artaxerxes II, which sanctioned the popular religious conceptions, and introduced them into the system of the Zoroastrian religion. Both Zoroastrianism and Christianity succeeded in gaining adherents and establishing themselves by conforming more or less to the ideas and customs of the people.

Jackson, in his Zoroaster, observes: 'Tradition, according to Brahman Yasht, asserts that Ardashir the Kayan, whom they call Vohuman, son of Spen-dat, and whom we know as Ardashir Dirazdast, or "the long-handed", is the one "who made the religion current in the whole world". Actual history agrees with this, in so far as it shows that Artaxerxes Longimanus, or "long-handed", was an ardent Zoroastrian ruler. From the pages of history we, furthermore, learn that by the time of the last Achaemenians, at least, Zoroastrianism is practically acknowledged to have become the national religion of the Iranians'. ${ }^{24}$ In the

23 It is seen by the Persian proper names compounded with the names of various Iranian gods, as Ed. Meyer points out, G. A., III, p. I26.

24 P. 133 f. A similar view is expressed by Darmesteter, Avesta, p. lv : 'Neiv progress marked the reign of Artaxerxes Longimanus'. He gocs even so far as to contend: - It was he who blended the worship of AnatMylitta with that of the Iranian Anahita (the ascription of that innovation to Artaxerxes Mnemon, by Clemens Alexandrinus (Stromata I) must rest on a clerical error, as in the time of Herodotus, who wrote under Longimanus, the worship of Analita had already been introduced into Persia)' (note 3). But Darmesteter's contention rests on a logieal error. Berosus (apud Clem.) does not state that the worship of Anahita was introduced by Artaxerxes II. He merely states that the latter was the first who 
light of our observations, the matter will be viewed differently. The later Persian scholars, and even the compilers of the Zend-Avesta which, as Renan observes, is a Talmud rather than a Bible, ${ }^{25}$ had no more exact knowledge of Persian chronology than the Talmudic Rabbis. The tradition of the dissemination of the Zoroastrian religion being due to Ardashir is undoubtedly correct, but the king of that name was not Artaxerxes Longimanus, but his grandson Artaxerxes Mnemon. Besides, we cannot find any historical source that presents the former king as an ardent Zoroastrian. Concerning the reference of Brahman Yasht to Vohuman son of Spen-dat we may perhaps see in it an obscure tradition referring to Haman ( $=" \Omega \mu \alpha \nu o s)$ son of Hamdatha. ${ }^{26}$

taught the Persians to worship anthromorphic images, in erecting statues of Anahita. Darmesteter evidently overlooked the fact that Herodotus himself, who informs us of the worship of Anahita by the Persians, distinctly states that the Persians knew of no images of the gods. Moreover, the same statement is given in his Exhortation to the Grecks, V, I, and it is unlikely that he should have committed twice the same error.

25 In his History, VII, I 4.

${ }^{26}$ Vohmman is rendered into Greek as Omanos, as Strabo, in his Geography, XI, I4, states: 'There were founded both the sanctuaries of Anaitis and of the associated gods, Omanos and Anadatos'. The latter names remarkably resemble Hanan and Handatha. Strabo further writes: 'These things were customary in the sanctuaries of Anaitis and Omanos'(XI, I6). The eleventh Persian month Vchumanah is called in

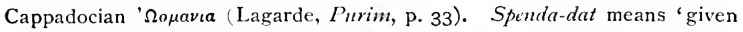
by the Holy Spirit' (Justi, Iran. Namenb.). Haoma, which is the most sacred and most powerful offering, comprising the life of the whole vegetable kingdom, and by drinking of it man will become immortal on the Day of Resurrection (Darmesteter, l.c., p. 69) may have been the symbol of the Holy Spirit. Thus Höm-data and Spendudat may be synonymous names. Pseudo-Smerdis, whom Darius in his Behistun-inscription calls Gaumata, is by Ctesias called Sphonda-dates (see chapter IX). Thus it seems that Spenda-dat is a priestly title, and not a proper name. In the light of these observations, Cassel's view, quoted above (chapter II/, that Haman and his

$\mathrm{H}$. 
The limited circle of the true Zoroastrians no doubt resented that innovation and corruption of the Persian religion, and must have denounced it as heresy. But the latter may have submitted sooner or later. We cannot say to what extent they went in their zeal for the preservation of the purity of the Zoroastrian religion. They may or may not have sacrificed themselves in their opposition to that innovation. But we can with all certainty assert that the only part of the populace which absolutely refused to comply with the royal will and become idolaters were the strictly religious Jews. The latter were, of course, marked as disloyal subjects. Defying the authority of the empire was nothing short of high treason, and could not be tolerated. The officials had to enforce obedience to the royal decree, without exempting any person, and could not grant special privileges to the Jews.

We have already observed that as long as the Persian religion was undefiled by idolatrous practices, the Jews in all probability boasted in the presence of the Persians and their officials that their own religion was closely akin to or identical with that of Zoroaster. The Persians could not but be flattered by the compliment paid to their own religion, it being of such a high character that non-Iranians pride themselves in having similar religious conceptions. This established good will and friendship between Persians and Jews. The favours granted to the Jews by the Persian kings may have becn due to that fact. Now the condition was different. In refusing to worship Anahita, the Jews showed that the Persian religion was not good enough for them. This could not fail to arouse the hatred

father belonged to the tribe of the Magians, is rather probable. Their names may have been priestly titles and not proper names. 
of the gentiles. It was of course the cause of arguments, and frequently led to personal attacks. The officials who had continually to punish the Jews for their stubbornness, and to settle the quarrels between them and their enemies, considered them a constant source of annoyance, a turbulent, disloyal element among a peaceful and loyal populace.

This was a period of religious persecutions, similar to those the Jews experienced under the reign of Antiochus Epiphanes, and frequently in the Middle Ages. Yet the former persecutions were somewhat different from the latter. The Jews were not ordered 'to forsake their own laws' ${ }^{27}$, but to recognize the supremacy of Anahita, and to worship her. The latter was the more dangerous to the Jewish religion. Seeing in the worship of Anahita a mere formality, many Jews pretended compliance with the will of the king without regarding such a step as apostasy from Judaism. These Jews, though bitterly resenting the force that compelled them to pay respect to idols they abominated, practically did not suffer any inconvenience, and still remained on friendly terms with their neighbours. The only victims of those persecutions were the strictly religious Jews.

We have seen that in post-exilic times the only mark of 'Jews' (יהודים) was the rejection of idols, and under Persian rule, that mark was obliterated. The business documents of the Persian period show that a large number of Jews of that time were engaged in commerce. We may well assume that this was the only course open to them for providing means of subsistence. A nation, as a rule, is not disposed to admit large numbers of forcigners into its country to take possession of the soil and to settle as 27 I Nace. 1. 4 I. 
peasants, unless as bondmen. And not every man is able to be an artisan. But primitive nations readily welcome people who serve as middlemen between producer and consumer. Men of that calling do not live crowded together, but settle, whenever afforded an opportunity, in localities where competition is not too keen. Thus scattered in small numbers throughout the provinces of the Persian empire, the Jews were scarcely noticeable, as long as they peacefully attended to their own affairs. The succeeding generations of the immigrants were in all probability not different in language, dress, habits, and many even in their names, from the people among whom they dwelt. Now and then some neighbours learned incidentally that those people had a peculiar creed of their own. But a casual observer would have held them to belong to the strict Zoroastrians. Even the keen-eyed Herodotus who noticed every feature of the Oriental peoples, did not know the Jews as adherents of a special creed. With the corruption of the Persian religion, the Jews were thrown back into the former state under Babylonian rule. Those who refused to participate in the worship of Anahita, pleaded that the faith they professed prohibited the worship of idols, and thus became known as adherents of a different creed. $\Lambda$ barrier was now being erected between Jews and Gentiles. The former could not faithfully adhere to their religion, without being recognized as 'Jews' (יהודים).

If there is any reliance on historical analogy, we may accept it as an indisputable fact that the innovation of Artaxerxes II introduced into the Persian religion was the cause of Jewish persecutions. It would be of no consequence whether there were records testifying to those events or not. We must bear in mind that the real 
sufferers were the zealous, pious Jews, who formed only a very small portion of the Jewish peoplc. The persecutions were, in all probability, occasioned at the time of the high festivals of Anahita, ${ }^{28}$ when the Jews, in refusing to participate in the festivities, sharply contrasted with the rest of the people. Only those denounced by malignant ncighbours suffered the penalty of the law. The Jews settled in small towns and villages where there were no sanctuarics of Anahita, could easily under some excuse stay away from the festivities without exposing themselves to any danger. The hatred caused by the refusal of the pious Jews to recognize the divinity of that goddess naturally reacted upon all the Jews, who were looked at askance by the people and the authorities. However, if they held their peace, and did not express any opinion averse to the Persian religion, they could not be legally punished. The execution of a number of Jews in the various centres of the Persian empire was not so important an event as to be recorded by historians.

But we have, as it would appear, some record of those Jewish persecutions by the Persians. Hecatacus, according to Flavius Joscphus, in his Polemics against Apion, states that the Persians erected tcmples and altars in Palestine, and attempted to turn the Jcws away from their religion. ${ }^{29}$ This statcment refers of course to the reform of the Zoroastrian religion by Artaxerxes II. ${ }^{30}$ The historian Graetz, in his History of the $\mathcal{F}_{\text {ezus }}{ }^{31}$ describes that event

2* See chapter VII.

29 Josephus, Contra Apionem, I.

30 Willrich (Jutaica, p. 92 ) does not believe this statement, and naively asks: "Who should have attempted in the Persian period to do so?' He ought to have read Graetz's Mistory of the Jea's and his references to Berosus before dealing with Jewish history.

31 German edition II, p. 208, and his nutes, Pp. flif ff.; Engl. edition I, p. 408. 
as follows: "The relations between the Judeans and the Persians were at the same time somewhat disturbed. The latter, influenced by foreign example, began to practise idolatry. The goddess of love, who under the different names Beltis, Mylitta, or Aphrodite, was constantly brought under the notice of the Persians, exercised a powerful influence upon them. The victories they had achieved, and the riches they had acquired inclined them to sensual pleasures. They were, thercfore, easily enthralled by the goddess and induced to serve and worship her. As soon as they had adopted this deity, they gave her a Persian name, and included her in their mythology. Artaxerxes II sanctioned her worship, and had images of her placed everywhere in his great kingdom, in the principal cities Babylon, Susa, and Ecbatana, as well as in Damascus and Sardes, and in all the towns of Persia and Bactria ... Thus the spiritual link which had bound the Persians to the followers of Judaism-their common abhorrence of idolatry-was broken.... Having compelled his own people to bow down to this newly adopted goddess of love, Artaxerxes tried, as it appears, to force her worship upon the Judeans; the latter were cruelly treated in order to make them renounce their religion, but they chose the scverest punishment, and even death rather than abjure the faith of their fathers.' This account of that event, though not exact in details in the light of our investigations, is in the main correct. Graetz did not see the real object of the introduction into the Persian religion of the cult of that goddess, nor the reason for enforcing her worship upon the Jews. It was certainly not due to a mere fancy of the king to make her worship obligatory on all inhabitants of the Persian cmpirc. The departure from 
the policy of his predecessors not to interfere with the creeds of their subjects was urged upon this king for political reasons.

However, Hecataeus was acquainted with the circumstances of that event only as far as it concerned the Jews of the province Judea. Here was the centre of the cult of Jahveh. The whole province almost exclusively inhabited by a people which detested idolatry was forced to the worship of idols. ${ }^{32}$ The disturbances caused by these proceedings must have been sensational, and excited wide-spread interest. Egypt, which a few years before the accession of Artaxerxes II recovered its independence from the Persian empire, and was continually in a state of war with the latter, must have watched with keen satisfaction the unsettled conditions in the neighbourland, and we may reasonably conjecture that it incited the Jews to rise against their oppressors and promised them its assistance. But the Jews may have profited by the experiences of their past, well knowing that the friendship of Egypt was just as responsible for the downfall of the states of Israel and Judah as the armies of Assyria and Babylonia," 33 and preferred to suffer rather than to rise in arms and 'to trust in the staff of this broken reed, on Egypt'. ${ }^{3 t}$ Hecataeus

32 As to the Samaritans, though they were worshippers of Jahveh, they were not yet pure monotheists, and still continued ' to serve their gods and to fear Jahveh', as the author of Kings described their religion. At any rate, their religious conceptions were not different from those of the former Israelitish inhabitants (see 2 Kings $17 \cdot 34-41$ ). The change in their religious conceptions belongs to a later period.

33 Both prophets, Isaiah $20.5,6 ; 30.3,4)$ and Jeremiah $(37,7)$, warned the Judeans not to rely upon the promises of the Egyptians, and not to rise against the Assyrians and Babylonians, and their state would have survived if they had accepted this advice.

$34=$ Kings 18.21 . 
who flourished in the fourth century B.C.E., and lived in Egypt as the close friend of Ptolemy I, was a reliable authority on the events of that period in Judea. But he had no information concerning the same kind of persecutions in the interior provinces of the Persian empire. Here the persecutions were not directed against a people but against individuals who resisted the royal decree. If numbers of them were on certain occasions imprisoned and executed, events of this kind were not so rare as to attract special attention.

While we have no external testimony for the latter persecutions, we are fortunately in possession of a biblical record testifying to that effect. We find such a record, evidently based on a true tradition, in the Book of Daniel, in the third chapter. The narrative, embellished with miraculous and anachronistic features, states: 'The king Nebuchadnezzar made a golden image of large dimensions and set it up in the Babylonian city of Dura. Then he assembled the princes, the governors, and the captains, the judges, the treasurers, the counsellors, the sheriffs, and all the rulers of the provinces, to be present at the dedication of that image and the performance of the rites. Then he proclaimed by heralds that all people, nations, and languages should fall down and worship the golden image at the sound of the music of the solemn service; and whosoever should not comply with the command, should the same hour be cast into the midst of a burning fiery furnace. Therefore all the people did as the king commanded. But Chaldeans came and accused certain Jews to have no regard for the king's commands, refusing to serve his gods and to worship the golden image. Then these Jews were brought before the king, but cven in his 
presence they remained stubborn, still refusing to do his command. Then they were bound and cast into the burning fiery furnace, but the fire had no power over them.' 35

Extremely divergent opinions are held concerning the historicity, contents, and tendencies of the Book of Daniel. But there can be no disputing that its author was of high intellect and well acquainted with Oriental customs. This account, however, seems so singular as to reflect upon the intellect of its author. Does it stand to reason that any polytheist should ever have refused to worship an idol, unless threatened by being cast into a fiery furnace? But divesting this account of all anachronistic and miraculous elements, it presents a plain historical tradition of the innovation of Artaxerxes. II introduced into the Zoroastrian religion; it describes how this king-as ruler of Babylon styled Nebuchadnezzarerected a golden image of Anahita in Babylonia, how he forced the Zoroastrians under the penalty of death to bow down to it, and the royal command was complied with by all except the strictly religious Jews. This tradition presents the antecedents of and the prologue to the Book of Esther. It bears at the same time testimony to the monotheistic character of the Zoroastrian religion and the high religious principles of its adherents, that only the choice between life and death compelled them to submit to the royal will. We may well assume that they deeply resented this command and secretly sympathized with its Jewish victims. How exact in some points this tradition is may be seen by the fact that this golden image is said to have been set up in Dura $=$ Der $=$ Divrilu, in North 
Babylonia, in the neighbourhood of Babylon. This locality was from ancient times the centre of Ishtar with whose attributes Anahita was invested. Just as the supreme Babylonian god Anu never possessed a centre of his own, ${ }^{36}$ but was always worshipped in conjunction with his daughter Ishtar, who was the representative of her father, so Ahuramazda was worshipped through his manifestation Anahita, and never possessed a temple of his own. There was indeed a burning fiery furnace. But it was not for the purpose of casting into it the recalcitrants to the worship of Anahita. This was the Holy Fire, the symbol of Ahuramazda. The Holy Fire would have been defiled by casting into it human beings. In this tradition we thus have an authentic record of that event, and of the Jewish persecutions in the East of that period.

It is of interest to find that tlie Talmud regards the danger impending over the Jews as punishment for their transgression in having submitted to the worship of the image described in the Book of Daniel. It is not impossible that the Talmud had some dim tradition as to the connexion of those two events. It is stated: ${ }^{37}$ "The Jews of that pcriod deserved destruction for having bowcd down to the image erected by Nebuchadnezzar; but as they mercly pretended to worship it, God intended to scare them as a punishment for their cowardice.'

36 The city of Erech was properly the centre of Nana-Ishtar, not of Anu.

37 Megillah i2a. But the Rabbis, led astray by Daniel's chronology, believed that the event of Purim occurred wilhin the seventy years of the captivity, and that $\Lambda$ hasucrus reigned not long after the death of Nebuchadnezzar (cf. ibid. I6a). 


\section{CHAPTER VII}

The author of the reform-The success of the reform among the Persians-The resistance of the Jews-The contrary effect of the persecutions upon them-Their plea-Esther's relationship to Mordecai-His identity among gentiles-The necessity of his having some position at the court-His discovery of a conspiracy-His attitude towards the persecuted Jews-His refusal to bow down to the prime minister-His confession of being a Jew-The prime minister's hesitation to punish him-His action and the creed of the Jews-The significance of the casting of lots-The simultaneity of Purim with a non-Jewish festival - The epagomena-Haman's difficult task-The Jews in Palestine-Haman's accusation-His aim-The sanguinary style of his decree-His promise of ten thousand talents His wealth-The king's investigations-The early promulgation of the decree -Its being reconsidered under the influence of wine.

IN the preceding chapter we learned from the pages of history that there was a Jewish persecution under the reign of Artaxerxes II. Turning to the Book of Esther, we are confronted by the fact that the chief executive of that king was an inveterate enemy of the Jews. We may thus safely conclude that those Jewish persecutions occurred at a time when this Jewish enemy stood at the head of the Persian government. But the persecutions could not have been due to a personal enmity of the prime minister towards the Jews. They were merely the outcome of the greatest movement in the spiritual life of the Persians since Zuroaster. On the other hand, we find that this minister 
occupied an extraordinarily high position, without seeing any cause for his elevation. Considering all these facts, we are justificd in looking for a logical connexion between the innovation of Artaxerxes II, the exalted position of his prime minister, and the enmity of the latter towards the Jews. This connexion we find in seeing in that prime minister who so severely persecuted those who did not willingly submit to the Zoroastrian reform the very author and originator of this idea. The author of the Book of Esther had no intention of writing Persian history. His sole aim was to explain the origin of Purim. He, therefore, wrote only the facts absolutely necessary for our information, ' of that which they had seen concerning this matter, and which had come unto them'. As to the other facts he refers us to 'the book of the chronicles of the kings of Media and Persia'. Moreover, the Book being compiled for the Jews of the Persian empire, the author could not touch upon the antecedents of that event, and refer to the cause of that prime minister's elevation, the corruption of the Zoroastrian religion, and the resistance of the Jews to that worship, without dceply insulting the adherents of that religion and endangering thereby the cxistence of the Jews.

The plan of reforming the Persian religion, by which it should gain popularity and be more easily disseminated among the subjects of the Persian empire, certainly did not originate in the muddled brains of an effeminate monarcli, but was devised, as already suggested, by one of the royal councillors. It was no doubt a very clever device for the purpose of establishing Zoroastrianism as the religion of the Persian empire. However, the introduction of that innovation was extremcly dangerous. 
Failure to realize it might have been disastrous to the dynasty, or at least, to the king. The Holy Wars, described in the Sacred Books of the Zoroastrians, which, according to Jackson and others, ${ }^{1}$ occurred in the sixth century B.C.E., could not have been forgotten in the course of two centuries. The great festival of the Magophonia established to commemorate the overthrow of Pseudo-Smerdis, who evidently had intended to abolish the Zoroastrian religion and to reintroduce the old Iranian popular belief, was, as Ctesias informs us, ${ }^{2}$ still cclebrated at that period. Some satraps, under the pretext of defending the purity of the Zoroastrian religion, might have caused an insurrection. ${ }^{3}$ The plan could not have met with the unanimous approval of the privy council. The strict Zoroastrians could not have been a party to the corruption of their religion, and naturally advised against that reform. The biblical tradition discussed above shows that the nobility and the officials were bitterly opposed to that innovation, and submitted to it only under the penalty of death. Many officials, though indifferent to religious principles, may have shrunk from being associated in the execution of that plan, knowing well that, if it should fail and cause disaster, the

1 Jackson, Zoroaster, p. I74; Alfred Jeremias holds the same opinion (The Old Testament in the light of the Ancient East, I, pp. 161 ff.) that 'Zoroaster's theology dates from the sixth century'.

2 Ctesias, Persica, 15.

3 We have already pointed out that the letter of Cyrus to the Lacedaemonians, in which he boasted of being instructed in the doctrines of the Magi, is not without significance. The Lacedaemonians had no concern whether Cyrus knew more of the religious doctrines than Artaxerxes. But he meant to indicate that in his enterprise he could reckon upon the assistance of the priesthood and the 'Church' party (see chapter IV, n, 21). Ardashir, who overthrew the empire of the Philhellenic Parthians and founded the New-Persian empire was a Magus Darmesteter, l.c., p. 55). 
king would hold them responsible, and willingly sacrifice them, to appease the anger of the people, as usually happens.

Impressed by the magnitude of the plan, and being convinced by the reasons advanced, that it was the best remedy for the prevention of the empire's dissolution, Artaxerxes entrusted the execution of the plan to its author. Such a sweeping and far-reaching plan could not have been carried through by a minister with limited powers. The satraps and governors of the provinces who were not favourably inclined towards the innovation might have interfered with his ordinances, and ignored them. The royal princes might have been too proud to receive orders from an inferior in rank. Therefore, committed to that policy, the king was bound to bestow upon this minister the highest rank, exalting him over all princes, grandees, satraps, and governors of the empire. Thus it was not a favour, but a grave task, conferred upon this councillor. By his elevation he was made responsible for the success of his advice. If the contrary of his intentions should occur, and the policy inaugurated by him should cause insurrections, he was utterly ruined. This councillor, of

Esther 3. r. course, we identify with 'Haman, the son of Hammedatha, whom the king promoted and advanced, and set his seat above all the princes that were with him'.

This councillor, however, appears to have been thoroughly acquainted with the religious sentiments of the Persian common people. The Iranians, though Zoroastrians and not worshippers of anthropomorphic images, never entirely abandoned the gods of the old popular belief. This fact is borne out by the numerous Persian proper names of the sixth and fifth centurics, which are compounded with 
names of old Iranian deities. ${ }^{4}$ The close intercourse with the Babylonians, Egyptians, Grecks, and other polytheistic nations for a considerable period was not without influence upon the religious conception of the Iranians. The latter became gradually reconciled to the idea of representations of the divine beings in which they continued to believe. Therefore the latter did not meet with any serious opposition among the Iranians. The strict Zoroastrians represented by the intellectual class, and many of the dignitaries, as it seems, though of considerable influence, formed only a small portion of the population, as Zoroaster's religion was too spiritual to attract real converts. None of them were courageous enough to raise the standard of rebellion for the religious cause. The polytheistic nations of the empire, which regarded the ruling Iranians as enemies of the gods, could not but be pleased with the religious change.

Nevertheless, the success of this reform was not quite complete. Resistance arose among a part of the population with which the prime minister never reckoned. In his official career, the Jews could not have been unknown to him, but like all the Persians who came in contact with them, he looked upon their religion as a variety of Zoroastrianism, and was not interested in finding out its exact nature. The Jew's for their own sake had good reason for upholding and corroborating these incorrect opinions, as we already observed. ${ }^{5}$ Therefore, it was to be expected that the Jews, like all other Zoroastrians, would submit

4 See chapter VI, n. 23 .

5 Marquart, Fundanente, p. 37, remarks: "It is probable that the Jews represented to Artaxerxes their God as being essentially identical with Ahuramazda, hence his sympathy for the Jews' (sec chapter V, note $5 \mathrm{r}$ ). 
to the religious reform. However, the Jews formed so insignificant a fraction of the inhabitants of the Persian empire that it may be seriously doubted whether the prime minister thought of them at all, and whether their submission or resistance ever entered into the calculations of his scheme.

But the resistance of the Jews was by no means immaterial to the success of the innovation. Numerically and in all other respects they were at too great a disadvantage to apprehend on their part any serious opposition, not to say, an insurrection. But one spark may set a building aflame where there is combustible matter. The dissatisfaction of the strict Zoroastrians with the corruption of their creed might have been stimulated by the example set by the Jews, and might have found vent in a Holy War, and this was certainly a subject of serious apprehension. Being informed of the resistance of the Jews, the prime minister instructed the officials to adopt the strictest measures against them. Receiving continuous reports from all parts of the empire of their obstinacy, his mind could not have been well disposed towards them. At first he may have tried rather lenient measures to render them submissive. But seeing the futility of bending them to his will in that way, he had no course but to break their stubborn resistance by imposing upon them the most severe sentences. The condemned, of course, gave vent to their imprecations on the author of their doom. Thus it happened that this prime minister became a persecutor of the strict adherents of the Jewish religion, and was looked upon as 'an enemy of the Jews'.

The prime minister was under the delusion that a number of exccutions in various sections of the empire 
would have the salutary effect of frightening the rest into obedience. But the effect of these executions was contrary to his cxpectations. The Persians had not yet had the experiences of religious persecutors, that blood is the best fertilizer for the growth of a religious creed. One martyr made numerous converts. As in former days, under Babylonian rule, the courage, devotion, and fervour of the martyrs reawakened the religious conscience slumbering in the hearts of many indifferent Jews. Many of the latter who by their conduct had not even been recognized as Jews, now openly declared their adherence to the Jewish creed, protesting against the cruel treatment of their coreligionists, and denouncing the author of those persccutions. We may doubt whether they went to the utmost limit of sacrificing themselves for their religion. But they were at least willing to share the disadvantage of being known as adherents of an unpopular creed. There may have been others less indifferent who. moved by the example set by their brethren, became strictly religious, and were ready to share the fate of the latter. The Talmud appears to be right in observing, that the Jews had again voluntarily accepted the Jewish religion, in the days of Ahasuerus. ${ }^{6}$

In former days, the Jews had been eager to demonstrate to the Persians that their own religion was closely akin to that of the latter. This policy had now to be abandoned ; for if the Jewish religion was based upon the same principles as that of Zoroaster, there was no ground why

6 Shabbath 88 b. The Talmud, however, in all probability did not know of these persecutions, and merely based its saying upon the verse: "The Jews confirmed and took upon themselves' (IX, 27), which they interpreted: 'They confirmed now (the Law) which they had taken upon themselves long ago' (קימו מה 'שקבלו כבר). 
it should not undergo the same change. The logical conclusion would have been that the opposition the royal decree met with on the part of the Jews, was not due to the fundamental principles of their religion, but to the obstinacy and disloyalty of its adherents. The Jews could plead their innocence only by demonstrating that their own religion prohibited the worship of idols, that 'their laws are diverse from all people'. They could easily refute the accusation of being disloyal subjects by pointing out that they had always recognized the divinity of Ahuramazda, the supreme God of the Iranians, and still continue to do the same, being thus more loyal to the Persians than all their polytheistic subjects who formerly had not the least regard for the Persian religion. This plea was irrefutable, but more harmful to their cause than silence. The Jews thus assumed the part of 'Defenders of the Faith', insisting upon the purity of Zoroastcr's religion. Now intolerance toward the creeds of the non-Iranians was not a part of the scheme of that innovation, as the recognition of Anahita did not restrain them from continuing to worship their own deities. The idea of toleration, however, did not work as far as the creed of the Jews was concerned. The prime minister perceived that the religious conceptions of these people were inimical to and incompatible with the execution of his measures. He saw in this religion the root of the evil which must be eradicated. It was against Persian political principles to be intolerant towards other religious beliefs, and he may have been reluctant to depart from them and apply measures for the suppression of the Jewish religion. The latter, however, the fundamental doctrine of which was: "Thou shalt have no other gods before me... for I the Lord thy God am 
a jealous God', could not expect tolerance from the believers in other gods, the existence of which it denied. But as long as those who resisted his ordinances were merely found sporadically, no great harm was done, and he was loath to use extreme measures against the practice of that religion. He saw that this fundamental doctrine was adhered to only by a small fraction of the Jews, and believed that with their extinction, it would be in abeyance, and no longer detrimental to the innovation. But the condition became more and more aggravated. This strictly monotheistic conception gained converts everywhere. An example of this kind we find in Mordecai.

The author of our story informs us: 'Esther had not Esther 2. showed her people nor her kindred'. Does the author 1o. intend to state that Esther kept secret not only her Jewish extraction but also her kinship to Mordecai? How could she have done so, since she was taken from Mordecai's house, and he went every day to inquire of the eunuchs about her ? ${ }^{7}$ If Mordecai was known to be a Jew, and anxious that Esther should conceal her connexion with the Jews, was he not afraid lest by his constant solicitude for her welfare the secret might leak out? The author could not be guilty of so flagrant a contradiction. This statement undoubtedly meant to imply that Esther concealed the fact that she belonged to those who were adherents of the Jewish religion. Since, however, Esther was actually of Jewish lineage, the author used the para-

7 Owing to the current interpretation of the Pook of Esther, this question has not yet found a satisfactory solution. Haupt, Critical Notes, p. 135, thinks that by some diplomatic questions Mordecai could have obtained some special information concerning Esther without revealing the fact that she was his cousin and foster-danghter. But this is impossible, since she was taken from Mordecai's house, as Paton, p. 175, and others object. 
phrase 'her people and her kindred'. Thus Esther kept secret her Jewish religion. ${ }^{8}$ But Mordecai did exactly the same. He was not known among the Gentiles to be a Jew. ${ }^{9}$ Thus there was no reason why Esther should have concealed her kinship to Mordecai. It was by no means necessary to be of pure Persian lineage to be regarded as Persian. Herodotus states that the children of Metiochus, the son of Miltiades, were accounted Persians. ${ }^{10}$ If Greeks could be so easily changed into Persians, why not Jews? Mordecai, like many other Jcws of that period, was in dress, habit, language, and, in all probability, even in his name, ${ }^{11}$ not in the least different from any other Persian. Having been an indifferent Jew, he was looked upon by his neighbours and casual acquaintances as a genuine Persian.

An obscure private citizen can easily conceal his identity, but not a high official who is constantly in the eye of the public which is naturally curious to learn all about his personality and pedigree. Esther, soon after her elevation to the rank of queen, procured for her cousin an office at the court. She might have done so, informing the king that Mordecai was related to her, without dwelling upon the fact that the latter was her cousin and had adopted her as his daughter. This she did after the downfall of Haman. Both Mordecai and Esther were anxious to conceal their identity, which could only be effected if the former remained in a humble position, fearing that the king on being informed of their close kinship might appoint the queen's adopted father to a high position. We

8 See chapter V, n. 63.

9 See chapter V.

10 Herodotus VI, $4 \mathrm{I}$.

11 We may reasonably assume that Mordecai had a Persian name (sce chapter $\mathrm{IX}$. The same is true of Nehemiah, cf. Marquart, Fundamente, p. $3^{x}$. 
may assume that even then the king was willing to bestow upon him some considerable office, but Esther, under some pretext, may have declined it. ${ }^{12}$ However, there is no need to assume that Mordecai owed his office at the court to the king's favour. The queen had only to hint at such a request to the chief of the eunuchs or to one of the high dignitaries to procure for Mordecai this position. Thus Mordecai became one of the guards, 'sitting in the king's gate'.

Was there any urgent need for giving Mordecai a position at the court? Mordecai, being a descendant of a wealthy family, was not in need of this position for his sustenance. Nor was he ambitious to pride himself on being a court official. We have seen that Mordecai's desire that Esther should captivate the king's heart was not due to his personal ambition, but to the forcthought that in time of need she might be helpful to the Jewish people. This plan showed, as we have observed, his solicitude for the welfare of his brethren but little regard for their tenets. This plan required that Mordecai should be in the proximity of the queen. As an attendant of the royal court, it was possible for him, by means of the eunuchs, in case of an emergency, to be in communication with the queen without attracting attention.

As one of the body-guards in charge of the gate of the Esther 2. royal palace, Mordecai was, of course, in intercourse and 21-23. on friendly terms with other attendants and eunuchs about the person of the king. Thus, on one occasion, he discovered a plot against the life of the king. This plot may be identical with the conspiracy against the life of Artaxerxes, which, if Aspasia, the concubine of Cyrus, did play any 
part in it, must have occurred not many years after the battle of Cunaxa, as was already suggested in the fourth chapter. In that case, the servant who, according to Plutarch, divulged that conspiracy, may be identical with Mordecai. Our text is here, owing to an error of a copyist, somewhat confused. We have to read: 'In those days, when the virgins were gathered together, the second time, and while Mordecai sat in the king's gate, two of the king's eunuchs, Bigthan and Teresh, of those which kept the door, were wroth' (מימים ההם בהקבץ בתולות שנית ומרדבי) . Our author intends to give the date of that conspiracy: it occurred at a time when virgins were gathered again. We have seen that gatherings of this kind were an oldestablished institution at the Persian courts, for the purpose

13 No commentator has as yet explained this passage. Wildeboer thinks that when a company of girls arrived pcople crowded into the court to see them, and that Mordecai took that opportunity to penetrate further into the palace than he could ordinarily go. Siegfried explains this clause as due to the clumsiness of the author. See the various views by Paton, pp. I $86 \mathrm{ff}$. But while sceking the explanation how Mordecai could have discovered the conspiracy at the time of the gathering of the virgins, they overlooked the main difficulty of that passage. This can have no connexion with the conspiracy, since it is separatcd from the latter's description by verse 20 : 'Esther had not yet shown her people nor her kindred, \&c.' However, a close examination of that passage shows that it is indeed misplaced. We notice in the first place that the clause 'Mordecai was sitting in the king's gate' is repeated twice in the verses 19 and $2 x$. Moreover, after the words בימים ההם we would expect בישבת מרדכי בישצר המיר

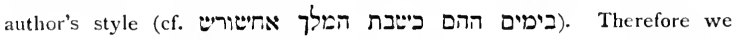

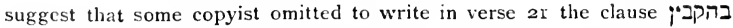
בתולו, and in order to show that it belongs after ביפים המית, he wrote on the margin perpendicularly, there not being enough space for בהקבין בהולות ישנית ומרדכי יוישב בשטר horizontal witing, both clauses במצt; and another copyist inserted them in a wrong place, in verse 19. Thus originally they had some connexion with the conspiracy. 
of replacing the faded beauties of the harem. ${ }^{14}$ We may assume that they always occurred when the various governors of the provinces sent to the court a sufficient supply. We are not distinctly informed of the nature of that plot. In the conspiracy of Darius, mentioned by Plutarch, the conspirators intended to murder Artaxerxes in his bed-chamber. In our case, the conspirators were 'of the keepers of the threshold' (משמרי הסף), who evidently guarded the entrance to the king's private chambers. This may be corroborated by the fact that they were eunuchs, while it was not a requirement of those 'who sat on the king's gate' to belong to that class. Therefore we may conjecture that it was a conspiracy of the same kind. However, there is a possibility that the clause, "when the virgins were gathered together, the second time', is more than a date, and has a deeper meaning. Did the conspirators intend to murder the king by pretendingr to introduce to him one of the newly arrived virgins? We may perhaps think of how Alexander of Macedonia, the son of Amyntas, destroyed the Pcrsian embassy by introducing to them beardless youths dressed in garments of women. $^{15}$ We may even imagine that one of the virgins may have been a party to the conspiracy in order to avenge the death of some relatives. We may recall the case of Phaedima, the daughter of Otanes, who played a very important part in the overthrow of Smerdis. ${ }^{16}$ Having been one of the guards, and on intimate terms with the other attendants, Mordecai may have been invited to join

\footnotetext{
14 See chapter IV, note 12.

15 Herodotus V, 20. Similar stories are told by many ancient writers, sec G. Rawlinson, Herodotus, vol. IV, p. 190, n 1.

16 Herodotus 111, 69.
} 
the conspiracy. The fact that he disclosed it reflects no credit upon Mordecai. The king's murder would have ended all his hopes and expectations of Esther's high position for the benefit of his brethren. He had more interest in the king's life than had any one else. The king, of course, could not know this, and we may safely conjecture that the latter, as a reward for his deed, was willing to appoint him to a high office commensurate with his merits. But Mordecai, as we have seen, could not have accepted this honour. ${ }^{17}$ The chief executive at that time saw no reason to promote Mordecai against his will, and was certainly well pleased with Mordecai's modesty. Nevertheless, his deed being recorded in the royal archives as that of 'a benefactor of the king', it was a valuable asset of which Mordecai could make use in time of need.

Considering that Mordecai was so anxious to advance the welfare of his brethren, the question naturally arises: Why did he not request Esther to intercede with the king on behalf of the persecuted Jews? Not having been strictly religious, Mordecai considered the recognition of Anahita a mere formality, and disapproved of the fanaticism of the strictly religious Jews. He saw in their obstinacy an act of self-destruction. We must bear in mind that, as already observed, Haman in all other respects did not interfere with the practices and observances of the Jewish religion. Moreover, Mordecai knew what importance the king attached to the innovation recently introduced into the Zoroastrian religion, sceing in it a panacea for his diseased empire, and had no expectation

17 Paton, p. 192: "Why Mordecai should not have been rewarded at once, but his services merely recorded in the annals, is hard to understand.' Similarly Siegfried and others see in it a defect of composition. 
that Esther's intercession with the king would be of any avail. In doing so, Esther might have endangered her position, and would have been of no further use to the Jewish cause. But notwithstanding his disapproval of the zeal of his brethren, blood is proverbially thicker than water, and his heart bled at the sight of their misery. Its author being the prime minister, Mordecai naturally heartily detested the butcher of his brethren.

All commentators on the Book of Esther have laboured in vain in secking a rational explanation for Mordecai's refusal to bow down to Haman, a homage certainly due to the chief executive and highest grandee of the empire. ${ }^{18}$ Modern exegetes, who see in the events narrated in this book pure fiction, regard this point as one of the principal defects in the composition of our story. We do not blame them, as the historical events of that period which form the background of our story and the antecedents of Haman's position were not known to them. But in the light of the present exposition it is clear that Mordecai in his state of mind could not have acted in any other way. Paying homage to the relentless persecutor and murderer of his brethren was for Mordecai out of the question. No Jew with a spark of honour could have stooped to so base an action. Thus it was not vanity that prevented Mordecai from doing obeisance to the prime minister. But we might still contend that it was imprudent of Mordecai to insult the prime minister, who was entitled to the honour of $\pi \rho \circ \sigma \kappa v \dot{v} \eta \sigma \iota s$, according to the Persian law, from all his subordinates. ${ }^{19}$. Mordecai should have spared

18 The old explanation that Haman claimed divine honours is of course fancy (see the various vicws by Paton, p. 196 f.).

1) Our author clearly states that it was a special command of the king. 
himself that humiliation by resigning his position at the court, and would thus not have to face the prime minister. The Talmud actually blames Mordecai for his conduct. ${ }^{20}$ However, we have to bear in mind that just at that period, when the conditions of the Jews became more and more precarious, it was more than ever necessary for Mordecai to remain in the proximity of Esther. He saw in his mind the time approaching when Esther's intercession would be the only means of rescuing his people. But even if Mordecai's conduct was unwise, the very fact that he dared to challenge Haman proves how deeply he was affected by the sufferings of his brethren. Carried away by his passionate hatred towards the persecutor of his people, he was unable to consider the inadvisability of insulting the former, and was even careless about his own safety. This conduct, if imprudent, redounds even more to his honour as a Jew than the great service he later rendered to the Jewish cause. In exposing his own life, Mordecai fully identified himself with the strict adherents of the Jewish religion.

Esther3.2. Thus while 'all the king's servants, that were in the king's gate, bowed, and reverenced Haman: for the king had so commanded concerning him, Mordecai bowed not, nor did him homage'. His odd behaviour could not pass unnoticed. His fellow keepers of the gate could not

Herodotus tells us about the method of salutation by the Persians: "Where the diffurence in rank is great, the inferior prostrates himself upon the ground.' Our author may mean that Haman was by his elevation, according to the Persian law, entitled to receive that salutation from all officials. However, it may have been a special command of the king that Haman, who occupied such a high position, should be saluted in that way by everybody; the king may have intended to show that he had appointed him as his alter cgo, and that his authority is like that of the king.

20 Negillah 13 a. 
conceive of a man in his sound mind committing such an action by which one could easily forfeit his own life, if it were reported to the authorities, and were naturally curious to learn the reason of his strange behaviour. 'Then the king's servants, which were in the king's gate, said unto Mordecai, Why transgressest thou the king's commandment?' It seems that at first he gave them an evasive answer or no answer at all, as he still kept secret the fact of his being a Jew. But as they became importunate, and repeated the same question 'from day to day', Mordecai finally broke his silence, and disclosed to them the real reason for his behaviour. His fellow keepers were to a certain degree responsible for his disrespectful behaviour, and threatened to denounce him to the proper authorities in case he should still refuse to explain it. Now he had to throw off his disguise, and frankly declared 'that he was a Jew', an adherent of the Jewish religion. ${ }^{21}$ It was a sufficient reason, and his fellow-keepers readily understood that as a man of honour he could not be expected to do homage to the persecutor of his co-religionists. But being responsible for his conduct, they may have advised him to leave the court and not expose his and their lives to the penalty of the law. They did not know that he accepted that office for the purpose of being near to the queen. He seems to have confided to them the fact that he saved the king's life, and assured them that being one

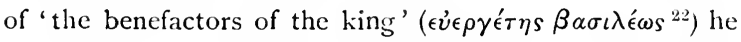
would not be punished, and could, if the worst happened, invoke the king's protection. It was a slim chance. Rcligious questions may have formed the daily topic of

21 It is clearly seen that he was not rccognized as a Jew.

22 See Herodotus III, 140 ; VIII, 85, and Diodorus XVII, ${ }_{4}$. 
their arguments, in which Mordecai exasperated his fellow officers by his opinions. The latter, to insure their own safety, had no other course but to report Mordecai's conduct, and convince themselves of the truth of his immunity, and in that case they would no more annoy him with their interference: ' and they told Haman, to see whether Mordecai's words would stand', that is to say, his assurance that he would not be punished. ${ }^{23}$

Esther3. 5. Why did Haman hesitate to punish Mordecai, as transgressor of the royal command, for his disrespectful conduct? The fact that Mordecai had saved the king's life could not have given him full licence to disobey consciously and persistently the royal command. The modern exegetes indeed regard this part of the story as highly improbable. ${ }^{24}$ It is no surprise that they are not able to comprehend this point. They labour under the delusion that the term "Jews' (יהודים) was a racial designation. It is perhaps due to the conditions of the Jews in the Christian era which left its impressions on their mode of thinking, that they cannot dissociate the idea of the Jewish religion from that of the Jewish race. They do not consider the possibility of a man being by descent, language, habit, and in all respects a genuine Persian, and nevertheless, as far as religion is concerned, a real 'Jew' (יהודי). This misconception lies at the bottom of all improbabilities and impossibilities we are confronted with in the actions of Mordecai and Esther. In the opinion of the modern commentators, Haman could not have been

23 Mordeciti must have declared that he would continue to do so with impunity. This is the meaning of the passage: 'to see whether Mordecai's words would stand' (היעבורו דברי מררכי).

24 See Siegiried, p 139; Palon, p. 74. and other conmentators. 
aware of the relationship between Mordecai and Esther, if he knew that the former was a Jew. For if he was acquainted with buth facts, he could not doubt that Esther was a Jewess, and the whole story would be impossible. Seeing, however, that Esther was taken from Mordecai's house, and their relationship could not have remained a secret, and Haman knowing likewise that Mordecai belonged to the Jewish race, the commentators cannot but condemn our story as impossible. Therefore we dwelt, in the fifth chapter, on this point to demonstrate that in post-exilic times, among Jews and gentiles alike, the term 'Jews' (יהודים) had a merely religious significance. Haman, who had trouble with the Jews and was naturally interested in them, was not unacquainted with the fact that there were many among them of non-Jewish origin. Mordecai's adherence to the Jewish religion was a private matter. He could have belonged to the highest Persian nobility, and be nevertheless by religion a 'Jew' (יהודי). not identify the idea of the Jewish religion with that of the Jewish race. Such an idea never entered into his calculations. He was not interested in racial probiems, but in the religious question. Esther was innocent of Mordecai's adherence to the Jewish religion, and he knew that as quxen she deported herself with the devotion of a true believer in the Persian religion. There is no doubt that Haman could have executed Mordecai for having persistently disregarded the royal command. Artaxerxes, who was so jealous of his authority, as we have seen in the fourth chapter, would certainly not have been lenient towards Mordecai, even if he was 'one of the king's bene-

25 In a later period, Izates, the king of Adiabene, embraced Judaism (Flavius Josephus, Antiquitics, $\mathrm{XX}, 4$. 
factors'. But Ilaman was too sagacious to act hastily in this case. He knew that Artaxerxes was completely under the influence of the harem. Assuming that the queen was naturally attached to her relative, Haman was afraid lest some day the queen might avenge his death. He could not have forgotten how Stateira, in order to avenge the death of her brother Teriteuchmes, had put Udiastres to a death too cruel to be described, ${ }^{26}$ and how Parysatis, by her intrigues, had destroyed all the nobles and eunuchs who saved the life and the throne of Artaxerxes in the battle of Cunaxa, in order to avenge the death of her son Cyrus. It was even dangerous to harm a relative of the favourite women of the king. Therefore Haman's policy was to be on good terms with the queen, and he did not dare to punish her relative. Subsequently, however, sceing from the special distinction with which the queen treated him that it was impossible that she should care much for her relative, or that she should have approved of his disrespectful conduct towards him, Haman did not hesitate any longer to inform the king of Mordecai's disobedience to the royal command, and to ask his permission for Mordecai's execution. ${ }^{27}$

26 Ctesias 57 .

27 Notwithstanding being all-powerful, Haman had to ask the king's permission for Mordecai's execution, and could not act on his own responsibility. Herodotus I, I37, informs us: 'The king shall not put any one to death for a single fault. ... Bnt in every case the services of the offender shall be set against his misdoings; and if the latter be found to outweigh the former, the aggrieved party shall then proceed to punishment'. Cf also the story of Sandoces who was taken down from the cross, because Darius thought that the good deeds of Sandoces toward the royal house were more numerous than his evil deeds, as told by Herodotus VII, r94. Haman as chief executive learned of Mordecai's act in saving the king's life. But that fact was not an absolute protection. So did Tissaphernes, to whom Artaxerxes owed his life and throne, and who was neverthcless executed. 
However, the conduct of Mordecai meant more than Esther 3.6. an insult to the dignity of the prime minister or a transgression of a royal command. His disrespect was a protest against Haman's policy. His endeavours to consolidate the empire by bringing the various inhabitants of the Persian empire into closer relations with the Persians was openly denounced and condemned. This was a matter for grave reflection. If his authority was defied in the very palace of Artaxerxes, how could he expect his ordinances to be obeyed in the provinces? Mordecai's conduct opened his eyes. He now fully realized that the numerous executions he had ordered did not produce the effect of frightening the Jews into obedience. Mordecai was not an eccentric individual, but a type of the Jews. He now clearly perceived that the religion of the Jews, unlike other religions, is detrimental to the welfare of the empire, as its existence was incompatible with the newly inaugurated innovation of the Zoroastrian religion. The Jewish faith being at the root of the evil, it had to be extirpated, by proclaiming its adherents traitors and criminals, even those who had hitherto not resisted the worship of Anahita, but still declared themselves to be 'Jews' (יהודים), and lived according to the observances of the Jewish religion. Haman now became the prototype of Antiochus Epiphanes. For the first time, the Jews were ordered 'to forsake their Laws'.

On the vernal New Year Festival, celebrated in Persia Fsther 3. 7. as well as in Babylonia, ${ }^{28}$ in which the gods determine the destinies of man for the coming year, ${ }^{29}$ Haman cast

${ }^{28}$ Haupt Purim, p. 3) remarks : 'The Persian Spring-festival . . . is no doubt based upon the Babylunian New Year's festival. It was celebrated at the vernal equinox'.

29 The gods were believed to assemble themselves in the chamber of 
lots ${ }^{30}$ to ascertain by divination the fate of the Jews, ${ }^{21}$ and the favourable month and day for their extermination.

Was the casting of the lots so significant an event as to afford a sufficient explanation for the name of Purim ? ${ }^{32}$ Astrology, according to Maimonides, ${ }^{33}$ borders on idolatry. But this expression is too mild. Astrology is to all intents and purposes identical with idolatry. The belief that the planets influence the fate of man can be sustained only by identifying them with the gods of the pantheon. ${ }^{34}$ The chief office of the Babylonian priests was divination, the most prominent of which was that based on the observation of the phenomena of the heavens. Diodorus, in dealing with the wisdom of the Chaldees, writes: 'The chiefs of these gods, they say, are twelve in number, to each of whom they attribute a month and a sign of the zodiac' ${ }^{35}$ The belief in constellations actually meant the recognition of the powers of the gods. If the people had seen in the planets inanimate heavenly bodies moving in obedience to

fate under the presidency of Bèl-Marduk to determine the destinies of man. Cf. Zimmern's theory on Purim (Keilinschriften und das Alte Testament, 1902, p. 514; Zeitschrift für altt. Wissen-ch., I891, pp. ${ }^{1} 5^{2}$ ff.). In Persia the determiner of fate was of course Ahuramazda. It goes without saying that upon the identical idea is based the Jewish New Year Festival which is held to be the day in which the fate of Israel is determined.

so Haupt (Purim, p. 19) shows many parallels to the eustom of casting lots on New Year.

st Haman did not only wish to discover an auspicious day and month for the execution of his plan, but also whether that plan would be approved by the gods. If he had not found an auspicious day and month, it would have shown that the gods disapproved of his plan.

32 Haupt (Purim, p. 3) and others deny it.

33 See Maimonides' letter to the men of Marseilles (cf. Stcinschneider's Hebräische Uebersetzungen des Mittelalters, 1893, 931).

34 Cf. Jastrow's Aspects of Religious Belief and Practice, ehapter V.

35 Diodorus II, 3. 
an inexorable law in nature, they never would have believed them to portend future events. Therefore, the prophet Jeremiah, in contrasting the power of the God of Israel with that of idols, prefaces his exhortation with the words: "Thus saith the Lord: Learn not the way of the heathen, and be not dismayed at the signs of heaven, for the heathen are dismayed at them '. ${ }^{36}$ The belief in the signs of heaven was contrary to that in the God of Isracl. As long as idolatry flourished, astrology was generally considered to be an idolatrous practice. In a late period, however, astrology assumed a different aspect. Judaism, Christianity, and Islam could easily demolish the statues and images of the gods held to govern the planets. But the belief that those heavenly bodies govern the fate of man could not be eradicated. Therefore, in order that the popular belief should not contrast with the established religions, it was tacitly admitted that the movements of the stars predict future events. And as astrology could hide itself under the wings of its scientific sister astronomy, and still cater to the superstitions of the people, it was a profitable profession, became a legitimate science, and was practised by Jews, Christians, and Mohammedans alike, ${ }^{37}$ without investigating its nature and origin. Thus astrology is not a remainder of polytheism, but its fundamental factor. The Jewish astrologers about the first century B.C.E., and probably also later, were well aware of the fact that their practice was identical with idolatry, and in order to absolve their conscience, substituted for the heathen deities as governors of the planets angels under the names Shamshi-cl (= Shamash), Kokab-cl (=Ishtar), Shabti-cl

36 Jer. 10. 2.

37 Cf. the article 'Astrology' (Blau and Kohler), in the Jcaish Encyc.

II. 
(= Ninib), \&c., ${ }^{39}$ who were in their names and functions the very images of the old gods of the pantheon. Thus to ascertain fate by divination and to select a favourable day and month for the execution of some enterprise means the practice of idolatry, as it presumes that each day and month stands under the rule of one of the gods. Though passages in the Talmud express the same notion that each of the seven days of the week is governed by planets, ${ }^{39}$ this could not have been the old Rabbinic conception. There is indecd a 'Baraitha' that distinctly states that this kind of divination was prohibited, in declaring that the biblical commandment, 'Ye shall not use enchantment' refers to

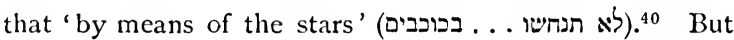
though these Rabbis condemned this practice, they could not stamp it as pure idolatry, since it was generally practised. It was different in the fourth century B.C.E., when the belief in divination was tantamount to that in the power of the gods, and monotheism and astrology were recognized as incompatible.

Now Haman's intention was to extirpate the Jewish monotheistic religion. The casting of the lots was the act of divination performed by the priests to inquire after the will of the gods. We may surely assume that this performance was not done secretly, but was solemnized in the temple with sacrifices and a stately service in the presence of the public. The execution of Haman's intention greatly depended upon the goodwill of the Gentile population,

${ }^{38}$ See the book Enoch, I, 6, 7 ; VII, 3. We are told that Barakicl taught astrology; Kokabel, the constcllations; Ezckacl, the knowledge of the clouds: Arakiel, the signs of the earth; Shamshiel, the signs of the sun; and Sariel, the course of the moon.

${ }^{39}$ Shabbath 156 a.

40 Sanhedrin 68 b. 
and he had to demonstrate that his action was commanded by the gods. Thus it was generally known that, according to those lots called in the Hebraized form 'Purim', ${ }^{41}$ the fate of the Jews was sealed. Any expression of sympathy for the cause of the Jews anong the Gentiles was silenced by the word 'Purim', indicating that no man may interfere with the will of the gods. It became, as we may say in modern parlance, the slogan of the enemies of the Jews. The conflict of Haman with the Jews was actually a struggle between Monotheism and Polytheism. ${ }^{42}$ Thus we can well conceive that those who instituted the commemoration of those events used the very battle-cry of their encmies as an appropriate name of that festival, ${ }^{43}$ expressing

4: It is improbable that Haman cast the lots out of superstition.

42 Cassel, p. 1o1, sees also in the casting of the lots a contrast between Judaism and paganism.

43 The question whether a Persian word pin', 'lot', is found, is irrelevant. What do we know about the old Persian language? The language of the Avesta had never been the Persian idiom. They are merely related dialects, but for the most part independent. As to Pahlavi, the language used in Persia under the Arsacides and Sassanides, it is a middle dialect between the ancient and modern Persian languages (Darmesteter, l. c., p. xxxiv). We may reasonably assune that our author would never have connected pir with 'lot' if he had not known that it has that meaning in the Persian language. Thus the emphatic assertion of Haupt (Purim, p. I6) and others that 'there is no Persian word piur, meaning 'lot', is rather daring. But we need not assume that pür is an original Persian word. There is no getting away from the fact that we have an equation pur = abnu, 'stone' ( $S^{c} 114$; Brinnow 6972). Now it is generally admitted that the Hebrew word 'lot', which our author identifies with pür, is etymologically identical with Arabic جَ, 'pebble'. P. Jensen was the first who suggested that pīr, 'lot' is connected with cunciform pur, 'stone' (Liter. Centralli., 1896, No. 50, col. r8o3), and he is no doubt right. Zimmern's objection that piru in the cuucilorm language means 'a sacrificial bowl or table' $=$ pashshīu $\left(K A T\right.$, p. $\left.5^{18}\right)$ does not invalidate Jensen's suggestion. The words furme and abnu incan 'a stone jug' (cf. Prince, Materials to a Sumerion Lexicon, 1908, p. 63). But the very fact that only 
at the same timc how deceptive the belief in the planetary gods is and thereby decrying their power. However, it is possible that the word 'Purim' is etymologically closely connected with the name of the old Persian festival Farwardigan. The latter may have sounded in the language of the old Persians more closely to the Hebraized form 'Purim'. Hitzig had already compared the latter with the modern Arabic Plunr, the name of 'the new year'.4t The casting of lots on the Persian new year festival may have been a general custom which Haman also used for detcrmining the fate of the Jews. The latter by adopting the name of the Persian new year as that of their own day of commemoration may have intended not only to commemorate the danger they had escaped but also to disguise the very nature of this festival in order not to offend the Persians.

a stone jug is called piuru, evidently shows that it bears this name on account of its material, and proves that piuru must have been a synonym of abnu, 'stone'. Granting, however, that pīru means only 'a sacrificial bowl or table', what do we know about the method of casting lots among the Babylonians and the Persians? Who may tell whether the lots were not put in a sacrificial bowl or upon a stone altar? We can well conceive that such a sacred act of divination, inquiring after the will of the gods, should have been performed in sacred vessels. We may call attention to the fact that stone vessels, according to the Rabbis (Mishnah Parah I, 2), cannot be defiled, and are used where absolute purity is required, as for "the Water of Separation made of the ashes of a red heifer' (Num. 19). The Persian laws of purification, and perhaps also those of the Babylonians, may have been similar to those of Israel (cf., however, Vendidâd, Fargard, $\mathrm{VII}, \mathrm{X}$. The Vulgate indeed translates: missa est sors in unnam quae Hebraice dicitur phur (ef. also Haupt, Purim, p. 20). When the Persians took over the New Year festival from the Babylonians, the customs connected with it and their terms were taken over at the same time. Thus the Persian word pür may be a Babylonian (and originally a Sumerian) loan. word.

44 In his Geschichte Israels, 1869. p. 280. 
The lot fell upon the month of Adar. It has been contended by numerous scholars that Purim originally was a non-Jewish festival. ${ }^{45}$ IVe believe that this contention is essentially correct. It secms, indeed, that there was a great Persian festival simultaneous with the Feast of Purim. We have already observed that the persecutions of the Jews, as a rule, occurred at the time of the high festivals of the Persians. All the year round people do not concern themselves with religion. Every man has his affairs to attend to, and cares little for the creed of his neighbours. It is different at the seasons of the festivals. The people, in high spirits, are fully devoted to their own creed and zealous for the honour of their gods. They see the Jews indifferent to their festivities, which indifference is, of course, interpreted as depreciation, and feel insulted. Their pride is hurt and their honour outraged. Some Jews may have been dragged by force to the temples, and murdered if they resisted. Others might have been compelled to express an opinion concerning the divinity of Anahita, and if it was unfavourable, might have been executed. We must bear in mind also that debauchery was always characteristic of festivities among common people. Being full of intoxicants and bereft of their senses, they were capable of committing atrocities. If Haman wanted the people to

45 Ernst Meier, Geschichte der poetischen National-Literatur der Hebrë̈r, 185o, p. 506; Julius Füst, Kanon de's A. T., p. 104; Hitzig, Geschichte des Volkes Isracl, ז869, p. 280 ; Zunz, ZDMG., XXVII, p.606; J.von Hammer, Jahrb. f. Litcr., XXXVIII, p. 49; Lagarde, Pmim; Renan, History, VII, 14 ; Schwally, Leben nach dem Tode, 1893, p. 42 ; Hommel in Weisslowitz's Prinz und Dinisch, 1890 ; Zimmern, $K A T$., p. 514 f. ; Jensen, in Wildeboer's Commentary, p. 173; Meissner, ZD.MG., L, p. 296; Winckler, Altoricntal. Forschmigen, 1I, pp. 9I ff., r8: ff., \&c. For the discussion of various views see Paton, pp. 84-94. 
rise against the Jews and exterminate them, he had no better opportunity to achieve his aim than on the day of some great festival. At any other time it was doubtful whether the people could be induced to murder the Jews in cold blood. Subsequently, when the Festival of Purim was established, there was no fear that this celebration might offend the feelings of the Gentiles, as it was simultaneous and to all appearance identical with the Persian festival. On the contrary, by its introduction, the danger of future persecutions was minimized. That fact sheds a good dcal of light on the attitude of the Sopherim towards the Festival of Purim, as we shall see further in Chapter IX. Now we have already suggested that the Book of Esther would never have been recorded if there had not been the fear that the event of Purim would sink into oblivion, and the festival would assume a non-Jewish character. ${ }^{46}$ We see now that the fear of such a possibility was not unfounded. The Festival of Hanukkah frequently coincides with Christmas, though these festivals have not the least connexion. And among some modern Jews the former festival recedes into the background and assumes the character of Christmas. Exactly the same would have happened with the Festival of Purim, and with more reason.

What kind of festival may the Persians have celebrated in the month of Adar? The worship of Anahita being the cause of the Jewish persecutions and of the decree for their extermination, it is safe to conjecture that it was one of the festivals of that goddess. Al-Boruni states that the Sogdians celebrated the five days of the epagomena at the end of the year. ${ }^{47}$ According to Paul de Lagarde, these five ${ }^{46}$ See chapter V.

${ }^{47}$ See Lagarde, Purim, p. 38. 
days were dedicated to Anahita. ${ }^{48}$ Lagarde and also other scholars believe that it was an 'All-Souls' Feast'. ${ }^{4}$ But we have the testimony of Strabo, who lived about a thousand years before Al-Berūni and knew the Zoroastrian religion while it still flourished better than did the Mohammedan author, that Anahita was a goddess of prostitution..$^{50}$ The festival of a goddess of that kind was not of a very solemn and noble character, as Lagarde would have us believe, and it must have resembled a carnival rather than a festival of the dead. Lagarde contended that the Festival of Purim is identical with that of the cpagomena ${ }^{51}$ We accept this theory, though Lagarde himself later abandoned it. ${ }^{52}$ We find a distinct trace of such a connexion with the cpagomena in the Mishna, which states: 'The Megillah may be read on the eleventh, twelfth, thirteenth, fourteenth, and fifteenth days of Adar, not earlier and not later'.53 These five day's of which there is no trace in the Book of Esther, ${ }^{54}$ scem to corre-

48 See Lagarde, Purin, p. 53.

49 Ibid., p. $3^{2}$. Schwally (cf. n. 45) and similaıly Spiegel (Eranische Alterthushsunde, 1878, p. 577).

on See chapter VI. However, we have already pointed out the fact that the Babylonian goddess Ishtar corresponded also to a chthonic deity, and the same may be true of Anahita (see chapter VI, n. 15). But there can be no doubt that in Armenia at least, Anahita was a goddess of prostitution.

${ }_{51}$ Bertheau-Ryssel, p. 372 and Paton, p 86, raise a great many objections to that theory, which are not unfounded.

52 Gött. Gel. Anz., 189o, p. 403.

53 Mishnah Megillah 2 a.

64 Now it is true the Mishnah explains very plainly bow it happens that the Megillah may be read on these five days. But this explanation may date from a late period. The Talmudic deduction from the term 'in their times' (בומצניהם), instead of 'in their time' (בista is harlly to be taken seriously (see the Talundic discussion on that subject). 
spond to the five days of the epagomena. Now it must be admitted that the dates of these two celebrations do not exactly agree, as the epagomena, according to the Jewish calendar, must have been celebrated by the Persians from the seventh to the eleventh of $\mathrm{Nisan} .^{55}$ However, we scarcely know anything about the customs of the Persian festivals in antiquity, and who may assert that these five days of the Persian and Jewish festivals were not simultancous? It is noteworthy that Pseudo-Smerdis seized the throne on the fourteenth of Adar. ${ }^{56}$ This also suggests that there was some festival on that day. The worship of Anahita properly belongs to the old belief of the Magi. Hence on the day of the festival of this goddess, the Magians attempted by the means of Smerdis to overthrow Zoroaster's religion, and to re-establish their own former religion. ${ }^{57}$ Thus the Magians who cast the lots and in-

55 The Persians had a year of 360 days which, with the five epagomena, constituted a solar year of 365 days. But the Jews lave a lunar year of 354 days. Thus there was a difference of eleven days between the Jewish and Persian first of Nisan. But we must consider that our knowledge of the Persian Calendar in the Achaemenian period is extremely scanty, as may be seen from the names of the montlis on the Behistur inscription which do not slow the least resemblance to those of the Avesta, Sogdians, Chorasmians, and the Neo-Persians (see Lagarde, Purim, pp. 29-32). The probability that there is some connexion between the epagomena and the Festival of Purim cannot be denied. If the former had been celebrated on the days of Passover, we might say that the Jewish festival was clianged to the fourtecinth of Adar, in order not to conflict with the other festival. Since, however, the efagomena were celebrated at the beginning of Nisan, the Jews could have done the same. Who knows whether the epagomena were not celebrated in the middle of the twelth inonth?

56 The fourteenth of Viakhna (Behistun inseription, col. I, 15) is identical with the fourteenth of $A$ dar (cf. Ed. Ifeyer's Forschungen, p. 472 f.).

57 Gco.ge Rawlinson r.ghtly contended that the accession of Pseudosmerdis, whercby the Ifedes regancel their ancicnt supremacy, was not 
formed Haman that Adar would be the favourable month for the execution of his plan chose the time which Haman himself would have chosen, without the means of divination.

Thus, in the first month of the twelfth year of Artaxerxes' reign, in the year 392 13.C.E., Haman planned to exterminate all the Jews of the Persian empire. It was no easy task for Haman to inform the king that the policy inaugurated by him causcd so much annoyance that he was forced to use the most extreme measures against those who opposed him. If the religious innovation had encountered the opposition of a warlike people, the downfall of Haman would have been inevitable. Artaxeres would have sacrificed him rather than uphold his authority and thereby cause a holy war. At that period he needed his army for other purposes. It was before the Peace of Antalcidas. The Jews, however, were powerless and defenceless. But what about the Jews in Palestine? Haman did not consider them at all. It goes without saying that, if the Jewish religion had been abolished, the existence of the temple in Jerusalem would have become impossible. It would have been either demolished or changed into a heathen sanctuary. From the statement of Hecataeus of Abdera we know that the Palestinian Jews suffered greatly under those persecutions, as described in the sixth chapter. ${ }^{\text {is }}$ The condition of the Jews in Judea was then hardly better than in the time of Nehemiah. They were still surrounded by hostile neighbours who were ready to attack them and to wipe out their semi-independent state. Jerusalem was

a national revolution, but the ascendency of the Hagian religion Herodolus, vol. II, p. 457). A similar opinion is expressed by Marquart (Fundtmente, p. ${ }_{4} 8$ ), and approved by Ed. Meyer (G. A., III, p. 123 '

ib Juscphus, Conlia Apioncm, I. 
now surrounded by a wall. However, the latter could only protect the city from a sudden attack on the part of hordes, and not against a regular army. There was no need for Haman to decree the destruction of the Judean state. The latter owed its existence to the grace of the Persian satraps. This province would have been lost if the Persians had withdrawn their protection and left it to the tender mercies of their hostile neighbours. ${ }^{59}$ Therefore

59 The question whether Ezra was a contemporary of Nehemiah is not solved yet. and is still a matter of dispute. Ed. Meyer (Entst. d. Jud., pp. 89-92) seems to have proved that they were contemporaries. However, Batten (Ezra, in the International Critical Commentary, New York, 1913, p. 28), still contends that Ezra belongs to a later period than Nehemial. Several of his arguments are not eonclusive, and were already discussed and refuted by Ed. Meyer. But there is one point of evidence against the latter's view that deserves serious consideration. We find that Ezra went into the chamber of Johanan, the son of Eliashib, to spend the night there (Ezra 10. 6). The succession of High-priests deseribed in Nehemiah (12. 22) shows that Johanan is identical with Jonathan (ibid., I2. I1), and that he was the grandson of Eliashib, as Stade, in his Geschichte dis Volks $I \mathrm{racl}, \mathrm{II}, \mathrm{p}$. I53, has already proved. If Eliashib was a contemporary of Nehemiah, Ezra seems to have lived two generations later, as Batten expresses himself ' exactly where he belongs, in the reign of Artaxerxes II'. However, even this point is not absolutely convineing. It is not quite impossible that the Johanan, to whose ehamber Ezra retired, is not identical with that Johanan who, according to Elephantine Papyıi, was High-priest in Jerusalem in 407 , as Wellhausen (Gött. Gel. Nachr., r895, r68) indeed suggests. Or it is not impossible that the compiler who revised the Ezra Memoirs, may have ehanged the name of the chamber, beeause in his time it was known under the name of 'the chamber of Johanan, the son of Eliashib', as Ed. Meyer thinks. Neither of the two opinions is quite satisfactory. In either ease we will have to encounter a great many difficulties. But one of them must be true. If Batten is right, this faet will shed considerable light on both the Books of Esther and Ezra, and it will be seen that both are elosely conneeted. The prayer of Ezra shows that the conditions of the Jews at his time were still unsettled, and that their existence was preearious. Batten further admits that there is no good reason whatever to doubt the genuineness of the edict of Artaxerxes II concerning the promulgation of the Law. Then the Law must have been 


\section{Iaman in his decree did not allude to the Jewish province in Palestine. He aimed chiefly at the Jews living dispersed}

promulgated about 396 , exactly at the time of Esther. We may notice, by the way, that the fact that the Law just now received official recognition may shed some light on the religious indifference of the Jews of that period. We might even assume that the Talmudic saying: "The Jews received the Law again in the days of Ahasuerus' Shabbath $88 \mathrm{~b}$ ), rests upon true tradition. But these are minor points. However, there are others of more importance. We see Ezra in high favour with Artaxerxes II. But we do not find the least reason why the king should have favoured him. If he had been an official, like Nehemiah, he would have informed us of this fact, as did Nehemiah. On the other hand, looking at the events of the Book of Esther, it seems strange that a Jewish woman occupying such a high position, who might, without disclosing her identity, confer many a boon upon her people, by predisposing the king in their favour, should remain quite indifferent to their welfare. But we notice a remarkable coincidence. In the seventh year of Artaxerxes II two events happened: In that year a Jewish woman became queen, and in the same year the Jewish Law received official recognition. Is it indeed a mere coincidence? Would it not be more logical to see a close connexion between these two events? Esther on her elevation may have called the king's attention to a people whose religion was identical with that of the Persians, and may have expressed the opinion that it would be good policy to support that creed, as the spread of the Persian religion in the Western countries would join them closer to the Persian empire. This opinion coincided with an advice urged upon him by one of the councillors to make Zoroastrianism the supreme religion of the empire, and thus prevent its disintegration. It is therefore reasonable that the same king who was desirous of disseminating his own religion for a pclitical purpose should promote the Jewish religion which he believed to be identical with his own. Hence Ezra, the priest and chief teacher of the Eastern Jews, was entrusted with the task of promulgating the Law. He must have known to whom he was indebted for that favour. But the man in whose eyes intermarriage with Gentiles was an unpardonable crime could not tell that he owed his own position to such an intermarriage. Moreover, it would have been wrong to disclose the secret of Esther and expose his benefactress to danger. In accepting Batten's date, another problem could be solved. The edict clothed Ezra with power to punish the disobedient with death, Lanishment, confiscation of property, or imprisonment (Ezra 7. 26). Nevertheless he was unable to effect a single divorce, except by a pathetic appeal to the people. Sumething must have happence in the mcantine which deprived Ezra of his power. 
among the other races, who might by their rebellious conduct incite others to imitate their example. If the Jews had lived together in large numbers, they might, indeed, have risen in arms against their oppressors, as they did in a later period, under the Romans in Cyrene. But scattered and dispersed in all provinces of the empire the Jews were incapable of offering resistance. ${ }^{60}$

The elevation of Haman occurred shortly after Esther had become the wife of Artaxerxes. We therefore conjecture that the decree concerning the worship of Anahita and the refusal of the Jews to submit to it, put an end to Ezra's power. We may further conjecture that the great fast the Jews observed on the tiventy fourth of Tishri occurred in Ezra's period, not in that of Nehemiah. There was not the least reason why under the reign of Artaxerxes Longimanus, the Jews should have fasted 'with sackcloth and earth upon them' (Neh. 9.. They certainly could not have complained: "They have dominion over our bodies and over our cattle, and we are in great distriss'. They had their own Jewish governor, who was the king's favourite, and certainly did not oppress them. But a short time after the arrival of Ezra and promulgation of the Law, the news about the grcat danger to the Jewish religion reached the Jews in Judea, and Persian officials were sent into the land to erect a sanctuary to Anahita. Therefore they fasted and made a covenant among themsclves to resist with all power the execution of that decree. Therefore 'the seed of Israel separated themselves from the strangers'; for 'no strangers ought to know that they intended to resist the royal decree'. This was not, as Batten (p. $3^{6} 3$ ) observes: 'Because the pure-blooded son of Abraham was alone a fit object for Jahveh's favour'. However, it must be admitted that the two dates of Esther and Ezra do not agree in every detail. Ezra arrived in the fifth month of the seventh year of Artaxerxes at Jerusalcm, and Esther became queen five months later. But the Boo's of Ezra and Nehemiah had been, as Ed. Mcycr and Batten pointed out, often revised. Thus we cannot expect the dates to be correct in every detail. It is possible that the edict of the promulgation was given in the seventh year, but Ezra's arrival at Jerusalem occurred in the fifth month of the eighth year of that king's reign. The preparations for such an enormons expedition must have taken a year at least. Thus if we accept Batten's date of Ezra in the light of the present writcr's exposition of the Book of Esther, all these events will be viewed differently, and numcrous prohlems will be solved (cf.chapter V, 11. 51 ).

tio No commentator has as yet satisfactorily explained the passage: 
'And Haman said unto King Ahasucrus, There is a Esther3.8. certain people scattered abroad and dispersed among the pcople in all the provinces of thy kingdom; and their laws are diverse from all people; neither keep they the king's laws: therefore it is not fit for the king's profit to suffer them.' Haman's accusation of the Jews and his advice to decree their extermination were worded very carcfully and diplomatically. But bis accusation was absolutely true. He did not slander them. And we indeed know from the Behistun inscription ${ }^{61}$ and from Herodotus ${ }^{62}$ that the most disgraceful deed for a Persian was to tell a lie. Haman prefaced his accusation by allaying the king's fear and forestalling any reproach, that by his advice he had plunged the empire into anarchy, in stating that the people which defies the king's authority is not dangerous in itself to the peace of the empire, being scattcred and dispersed in all the provinces of the empire. But by its disobedience it sets a bad example to others and destroys the king's authority. Our author seemingly does not state that Haman expressly mentioned the name of the people he accused. That he actually did mention it, we may deduce from the peculiar cxpression wי', literally 'its being', and thus referring to a preceding noun. ${ }^{63}$ The author gives only the substance of

'There is one people scattered and dispersed among the people'. This cannot be a part of the accusation. Such a condition is surely no crime, but a misfortune. Nor can it refer to the barrier of the Law, as Paton, p. 203, explains. The latter idea is expressed in the following sentence: 'Their laws are diverse from all people'. Hence that passage expresses the idea of disregard; their condition is so pitiful as not to fear their resistance.

61 Behistun inscription, col. $5+\mathrm{ff}$.

62 Herodotus I, I39.

63 The expression 'ני does not mcan 'there is'. The same form occurs also elsewhere three times (Deut. 29. I4; I Sam. I4. 39 ; 23. 23), where 
Haman's report, which, of course, exhaustively dealt with the Jewish problem. Herodotus or any Greek writer would have used for this report a full chapter.

If we had no proof that Haman aimed at the destruction of the Jewish religion and not of the Jewish race, we could deduce his intention from the words of his accusation in stating: 'their laws are diverse from all people; neithcr keep they the king's laws'. The first part of this statement is no accusation. It is no concern of the king, whether the laws of this people are peculiar or not, as long as they do not interfere with the laws of the empire. But Haman asserted that those laws are contrary to those of the empire, and prevent them from complying with the latter. Thus, there must have been Persian laws inconsistent with those of the Jews. Here we have a further corroboration of our description of the events of the period in which the Jewish religious conceptions came into conflict with the Persian laws. But if the Jewish religion is obnoxious to the welfare of the empire, it cannot be tolerated and must be suppressed, and the king would certainly have answered: 'Lct them abandon their religion, and if they refuse, you have my permission to destroy them.' This is exactly what Haman requested the king to do, in continuing to say: 'It is harmful to the king's authority to be indifferent toward their transgression of the Pcisian laws'.

Esther 3. Haman certainly was an enemy of the 'Jews', as the I3. author styles him (צורר היהודים), but not of those of Jewish extraction, as soon as they ceased to be 'Jews', in abandoning their religion. Now it is true the style of Haman's

it refers to a preceding noun. Sec chapter III on the impossible assumption that the king shonld have condemned a people to extermination whose name he did not know. 
decree is so sanguinary as to represent him as the very cmbodiment of wickedness. But Haman is not responsible for that style, nor is the author of the Book of Esther. The heaping of synonymous expressions, 'to exterminate, to kill, and to destroy' (להשמיר להרוג ולאבר) is inconsistent with the terse style of edicts. Haman's decree nust have been worded differently. Our author was a good historian and well acquainted with the style of edicts. Even if Haman had intended to exterminate the Jewish people without regard to their religion, there was no reason for the murder of little children. They could have been sold as slaves, and thus be of more profit to Haman or the people. Those exaggerations are certainly due to late interpolators, as suggested in the first chapter. The Greek version of our story has, no doubt, the original text of this passage. For

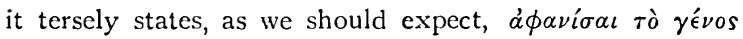

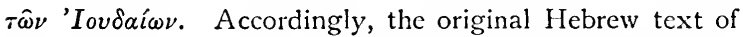
this edict must have been לאבר את (עם) היהודים, 'to destroy (the people of) the Jews', or a similar phrase. It is intercsting to notice how consistent both the Hebrew and Greek versions are. The former explains the hatred of Haman towards the Jews, by the statement: 'And he thought scorn to lay hands on Mordecai alone; for they had showed him the people of Mordecai'. WVe have already remarked that this improbable explanation is a late intcrpolation at a time when the real cause of Haman's action was no longer known. A man who is able to destroy a whole race on account of a single individual who insulted him, is certainly to be credited with any inhuman monstrosity. The Alexandrian translator, howcver, did not know of that passage, and in accerdance with this, the version of Haman's decrec is noi sanguinary. 
Esther3 9. Ilaving convinced the king that the conduct of the Jews could not be tolerated, Haman submitted this proposal: 'If it please the king, let it be written that they may be destroyed: and I will pay ten thousand talents of silver to the hands of those that have the charge of the business, to bring it into the king's treasuries'. If the Jews were disloyal subjects and according to law deserved to be exterminated, why should Haman promise ten thousand talents for the royal permission to rid the empire of criminals? Though the victims of the persecutions may have numbered many thousands, nevertheless they represented, as we observed, merely a very small portion of the Jewish communities throughout the wide dominions of the Persian empire. We have no census of the Jews of that pcriod, but at a very conservative estimate, they must have numbered many hundreds of thousands. ${ }^{64}$ The average Jews submitted with a bad grace to the innovation, as the Rabbis correctly perceived, since they saw in the worship of Anahita a mere formality forced upon them, and had no inclination to expose themselves to persecution by their refusal. Thus the friendly relations between them and the Gentiles were not disturbed. This being so, it was doubtful whether Gentiles in many localities, seeing no reason for the wholesale massacre of their Jewish friends and neighbours against whom they felt no animosity, would

64 About 140 years before that event, the Jews who returned from the captivity numbered 42360 (Ezra 2. 67). The larger part of them had no inclination to leave Babylonia and expose themselves to the laborious task of rebuilding the home of their ancestors. It is a low estimate to assume that about 100,000 stayed behind, who preferred to move into the interior provinces of the immense empire, where as merchants they had the best opportunity of accumulating riches. Thus within 140 years they may have increased to a number of many hundred thousands, at the lowest estimate. 
not resent those edicts and prevent their cxecution. The Jews, assisted by the population, could easily offer resistance against the force entrusted with the execution of those edicts. Therefore, to be sure of success, Haman appealed to the lowest passion of the people-greed. The lower strata, which form everywhere a considerable, if not the major, portion of the populace, are always willing to go to any extent, if they are afforded an opportunity of enriching themselves at the expense of their wealthy fellow-citizens. The Jews being mostly engaged in commerce were reputed to be very wealthy. In granting permission to the populace to keep the property of the Jews, Haman could reckon with full certainty on the carrying out of his edicts to the letter. ${ }^{65}$ But how could he dispose of their property? If the Jews were condemned for their disloyalty, they were traitors, and their goods had to be confiscated to the treasury. ${ }^{86}$ Thus it was necessary to reimburse the treasury for the loss it would have sustained by Haman's largess to the populace.

Have we ground to consider-as many commentators $\mathrm{do}^{67}$--the sum of ten thousand talents as an estimate of the Jews' wealth, which would amount to about eightecn million dollars, an exaggcration and incredible? As far as the Jews' wealth is concerned, the estimate was far too low. Concerning Haman's ability to supply that sum of his own means, if we believe Herodotus that the Lydian Pythius offered Xerxes for his campaign against the Grecks 'two

6i Paton, p. 209, correctly explains: 'This is offered as an inducement to the people to attack the Jews.'

66 The property of criminals was confiscatel by the Stite. See Herodotus III, 129, and Josephus, Antiquities, XII, i. 4.

${ }^{7}$ Cf. Haupt, Purim, p. 6 ; Paton, P. 206, and others.

II. 
thousand talents of silver, and of gold four million Daric staters, wanting seven thousand ', 68 which would amount to about twenty-four million dollars, ${ }^{69}$ we have no reason to doubt the statement of our author. ${ }^{70}$ We may recall the immense fortunes the Roman governors amassed in a few years. The Persian satraps had the same opportunities. Haman was no doubt a satrap before he became prime minister. We may assume that his father and his progenitors had served in the same capacity. Thus he may have possessed untold riches.

Esther 3. 'And the king took his ring from his hand, and gave it IO, II. unto Haman the son of Hammedatha the Agagite, the Jews' enemy. And the king said unto Haman, 'The silver is given to thee, the people also, to do with them as it seemeth good to thee.' By Haman's offer, the king became convinced of his unselfish motives, and fully granted his request to rid the empire of those internal enemies. We might, perhaps, doubt the statement of the king's generosity in bestowing upon Haman a gift of ten thousand talents. But we find a similar statement by Herodotus of Xerxes' generosity, who declined the offer of the Lydian and said: 'The seven thousand staters which are wanting to make up thy four millions I will supply, so that the full tale may bc no longer lacking and thou mayest owe the completion of the sum to me. Continue to enjoy all that thou hast acquired hitherto '.11

68 Herodotus, VII, 2 7-9.

${ }^{69}$ Cf. G. Rawlinson, Herodotus, vol. III, p. 25, n. I. According to Cassel, p. Iro, however, the sum that Pythius offered to Xerxes would be 9,986 talents, thus about equivalent to that offered by Haman to Artaxerxes; for five darics = one mina, and roo minas $=$ one talent. As to the immense riches of the satraps, cf. Herod. I, 192.

70 Similarly G. Rawlinson in his commentary on Esther, 1873 .

i) Herodotus VII, 29. 
However, did the king actually believe Haman's accusation and give him full permission to deal with the Jews as he deemed proper, without any further investigation? The Persians were certainly reputed in antiquity for their high sense of justice, as Xenophon represented them in his historical romance Cyropacdia. ${ }^{22}$ Thus how could we believe that Artaxerxes condemned a whole people without being certain of their guilt? Our author was not an orator, like the Greek writers, as we observed, and condensed Haman's accusation into a few sentences. Haman naturally dwelt thoroughly on that subject, and laid before the king the reports of the governors and officials concerning the disloyal conduct of the Jews and the disturbances everywhere, and corroborated each point of his accusation by absolutely reliable documentary evidence, and, perhaps, also by the personal testimony of many satraps and governors. Convinced of the guilt of the Jews by that evidence, and persuaded by the prime minister of the futility of any other remedies to reduce them to obedience, the king could not but grant Haman the permission to exterminate them.

The letters commanding the Jews' extermination were Esther 3 . written on the thirteenth day of the first month and 'were I 2 - I 4 . sent by posts into all the king's provinces, to kill ... all Jews . . . in one day, even upon the thirteenth day of the twelfth month, which is the month Adar, and to take the spoil of them for a prey. The copy of the writing for the commandment to be given in every province was

72 Cf. I, II, 6, 7, I5; I, III, I6-18. Though Xenophon actually meant to depict the Lacedaemonians, nevertheless he never would have dared to attribute those virtues to the Persians if they had not had a high reputation for the conception of justice. 
published unto all people, that they should be ready against that day.' Why did Haman promulgate the decree about a year before its execution? Seeing that the modern commentators consider Haman an inveterate enemy of the Jewish race, we expect to find the explanation of that early promulgation of the decree as being directed to enhance the sufferings of the Jews by keeping them in suspense as long as possible. ${ }^{73}$ Other commentators believe that it was done to give the Jews an opportunity to leave the country. ${ }^{74}$ The latter explanation is certainly strange. We cannot impute to scholars ignorance of geographical knowledge and of the extent of the Persian empire at that period. Seeing that those scholars identify Ahasuerus with Xerxes, the whole of Asia, with the exception of the Ionian free cities and islands, and Egypt, were under Persian dominion. Where could the Jews have found a refuge if they had left the Persian empire? Where could the Jews living in Parthia, Bactria, Sogdiana, \&c., have gone? Those of Asia Minor might have sought a place of escape in the Ionian free cities. Would the latter have admitted them? Certainly not as free citizens. At the time of Artaxerxes, the Jews of the province of Judea could have escaped to Egypt, as their people did two hundred years before. However, the early promulgation of the edicts greatly redounds to the honour of Haman. He was loath to commit that wholesale slaughter, if he could avoid it. His intention was to give the Jews ample time for reflection whether it would not be more advisable to desist from their obstinacy and to abandon their exclusive position among the nations, in parting with their singular creed. That early promulgation is a further confirmation of our

${ }^{73}$ So Bertheau-Ryssel and others.

is So Keil, Rawlinson. 
exposition of those events, that Haman's object was the destruction of the Jewish religion, which could not be accomplished without destroying the adherents of this creed.

'The posts went out, being hastened by the king's Esther 3 . commandment, and the decree was given in Shushan, the I5. palace. And the king and Haman sat down to drink; but the city of Shushan was perplexed.' The statement that the king and Haman sat down to drink has a deeper meaning than generally assumed. The modern commentators are on the wrong track in explaining: 'It is meant as a very effective piece of contrast. Orders have been sent out that will throw the empire into confusion, but the king and his prime minister enjoy themselves after finishing this troublesome business.' is This passage again shows how minutely our author was acquainted with Persian customs. Herodotus states: 'It is also their general practice to deliberate upon affairs of weight when they are drunk; and then on the following day when they are sober, the decision is put before them by the master of the house in which it was made; and if it is then approved of, they act on it ; if not, they put it aside. Sometimes, however, they are sober at their first deliberation, but in this case they always reconsider the matter under the influence of wine.' ${ }^{76}$ Thus our author means to state that the decision to exterminate the Jews was made when the king and Haman were sober, and it was reconsidered under the influence of wine. In the light of this explanation we understand the meaning of the clause: 'and the city of Shushan was perplexed'. This passage has not yet found any reasonable explanation. The exegetes cannot believe that the Gentile population

${ }^{75}$ See Paton, p. $21 \mathrm{r}$.

26 Herodotus I, r33. 
of the capital would have felt any great grief over the destruction of the Jews. Now the news reached the people that there was a deliberation concerning the destruction of the Jews, and that it was agreed upon. Still it was not certain whether this decision would not be set aside in the second deliberation under the influence of wine. Thus the people were perplexed and kept in suspense; their curiosity was aroused. Some held that the decision would stand, and some denied; some approved and some disapproved it. The passage apparently is not in the proper place. We have, perhaps, to read: "The king and Haman sat down to drink and the city of Shushan was perplexed; the posts went out, hastened by the king's commandment, and the decree was given in Shushan the palace' (נהמלך והמן ישבי לישתות והעיר יטושין נבוכה הרינים יינאו דחופים בדבר המלך והרת נתנה

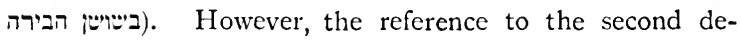
liberation under the influence of wine may have been an afterthought of our author. 
CHAPTER VIII

The effect of the decree upon Mordecai-His sources of informationThe numerous Jewish eunuchs-Esther's attitude towards the calamity of the Jews-Mordecai's message-Esther's arguments-Mordecai's threatsEsther's compliance-Her omission to request an audience of the king-Her difficult task-Her diplomacy-Her invitation of Haman-The advice of Haman's friends-The gallows-The incident of the honouring of MordecaiThe king's inquiry-His suspicions of the prime minister's disloyalty-The king's apparel-A lesson in modesty - The king being ignorant of Mordecai's creed-Haman's reflections-The deliberation under the influence of wineEsther's accusation of Haman-The king's indecision-Haman's plea with Esther - The king's ridiculous accusation of Haman- The covering of Haman's face-His denunciation by Harbonah-A parallel between Tissaphernes' and Haman's fate-The partiality of the Jewish point of view.

IN the preceding chapter we have dealt with the events which led to the promulgation of a decree for the extermination of the Jews that almost sealed their doom. The reform of the Zoroastrian religion and the Jews' resistance to the worship of Anahita being incontestably historical facts, there is no room for doubting the historical character of the danger impending over the Jews recorded in the Book of Esther. Based upon these facts, it has been pointed out at the starting-point of our investigation, that even if the Book of Esther had never been written, historians might have found out that at the period in which we place that event the Jews were threatened with complete extermination, and that the main question is not whether such an event ever did happen, but how the Jews escaped that danger. But the reality of their escape cannot be questioned either. Yet there is no external 
evicence to account for this event. Thus, without the story of the Book of Esther this fact would be historically unexplainable. The solution of this historical problem begins with the fourth chapter of our story.

Esther 4. The description of Mordecai's conduct on perceiving the doom of his people seems to indicate that he did reproach himself for his imprudent conduct toward the prime minister, seeing in it the cause of the disaster, and in repentant mood, as an expression of his regret, 'rent his clothes, and put on sackcloth with ashes, and went out into the midst of the city, and cried with a loud and a bitter cry'. Such an interpretation would be indeed permissible, if Haman's decree had been due to private motives: his personal hatred of Mordecai. But it has been sufficiently proved that this was by no means the case. Thus, concerning this point also the conception of the commentators is erroneous. Mordecai might have acted in the same manner, even if he had never come in contact with Haman. The third verse of this chapter distinctly states: 'And in every province, whithersoever the king's commandment and his decree came, there was great mourning among the Jews, and fasting, and weeping, and wailing; and many lay in sackcloth and ashes'. It is thus seen that many other Jews who never came into collision with the author of the decree, and had no reason for self-reproach, did exactly the same. Being at the court, Mordecai lnew that Haman's decree was not actuated by personal revenge. It was not to be expected that the ineffectual fines, imprisonments, and executions of those Jews who refused to recognize the godhead of Anahita should go on for ever. A crisis was inevitable. Being the first to learn of Haman's decree, Mordecai went 
into the city to inform his brethren of it, and to deliberate with them on the proper measures to be taken for its repeal. Here he bitterly complained to the population at the wrong done to the Jews, and no doubt vehemently denounced the prime minister for his inhuman decree, appealing to the compassion of the populace, in whose hands the destiny of the Jews lay. This may be the real meaning of the passage: 'And he cried with a loud and a bitter cry' (ויזעק זעקה גדולה ומרה). Not being decently dressed, Mordecai could not enter the king's gate: 'for none might enter within the king's gate clothed with sackcloth '. ${ }^{2}$ It might appear as if Mordecai had become indifferent to public opinion, being unconcerned whether the people should ridicule his behaviour or not, when he was making a spectacle of himself, in sitting before the king's gate

1 The exegetic addition of the Greek version: "Saying, an innocent people is condemned to death', is well conceived, since Mordecai could not bave acted in that manner, without expressing the reason for his grief in

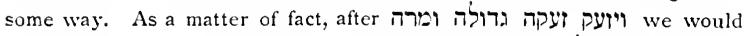

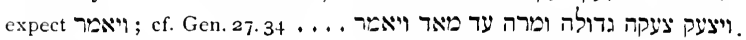
For the various additions of the Targumin, see Paton, p. 213 f. Cf., however, Cassel, p. I34.

2 The royal court was not a lounging place for beggars and tramps, and only richly or well-dressed people were permitted to enter there. WVe are not distinctly informed whether Mordecai did make any attempt to enter within the gate and was refused admittance by the guards. But he evidently did not. If he had claimed admittance as an official in this strange attire, he probably would have been arrested for debasing his official dignity. Cassel, p. 137, thinks that sackcloth was a sign of mourning for the dead, which was considered ceremonially unclean, and for this reason Mordecai could not enter the palace. So also Paton, p. 21.4. But it was well known that Mordecai did not mourn for a dead person. We might as well maintain that no weeping person could have entered within the king's gate. We may perhaps suggest that being an official, Mordecai had to wear a certain court dress or the military dress of the guards, and therefore could not enter attired in sackcloth. 
dressed in sackcloth. It seems more likely, however, that Mordecai's very intention was to arouse the curiosity of the people by his sensational conduct. He was well aware of the fact that the condition of the Jews was hopeless, if Esther could not be prevailed upon to intercede for them with the king. But he could not communicate at will with Esther. His only means of communication with her was to send her occasionally a message through one of her confidential eunuchs, if he happened to see one, or when she desired to communicate with him. Therefore, Mordecai expected that his strange conduct attracting general attention would not fail to reach one of her confidential eunuchs, who, of course, would inform his mistress of it. The latter's curiosity being aroused, she would certainly send somebody to him to learn the reason for this conduct. Then there would be an opportunity to inform her of Haman's decree, and to request her to intercede with the king on behalf of the Jews.

Esther 4. 'So Hathach went forth to Mordecai unto the broad 6-8. place of the city, which was before the king's gate. And Mordecai told him of all that had happened unto him, and the exact sum of the money that Haman had promised to pay to the king's treasuries for the Jews to destroy them. Also he gave him the copy of the writing of the decree that was given out in Shushan to destroy them, to show it unto Esther, and to declare it unto her; and to charge her that she should go in unto the king, to make supplication unto him, and to make request before him, for her people.' According to this statement, Mordecai had been informed not merely of the decree published in Susa, which was generally known, but also of the circumstances of the issuing of this decree, which could scarcely 
have been generally known. The question now arises: What secret sources of information were at the disposal of Mordecai that enabled him to inform Esther, how Haman had obtained his decree? For the answer to this question, which has an important bearing on the veracity of other passages of the Book of Esther, it is necessary to enter into a discussion of the institution of the eunuchs in the Persian period.

It would seem reasonable to regard the statements concerning Haman's casting of the lots, his speech to Ahasuerus, and his deliberations with his friends, of no more historical value than the speeches Herodotus ascribed to Otanes, Megabyzus, \&c., on the occasion of Darius' election. ${ }^{3}$ This is, indeed, the consensus of all modern commentators. A due consideration of the historical conditions, however, will make it evident that the statements of the Book of Esther ought to be judged differently from those of Herodotus. We know from Herodotus that Babylonia's annual tribute to the Persian empire was a thousand talents of silver and five hundred boy-eunuchs. ${ }^{4}$ Now it seems improbable that there should have been a large number of eunuchs of Persian origin, ${ }^{5}$ as Herodotus states: 'Next to prowess in arms, it is regarded as the greatest proof of manly excellence to be the father of many sons. Every year the king sends rich gifts to the man who can show the largest number.' ${ }^{\prime}$ The same idea

3 Herodotus III, 8o. 8I ; see G. Rawlinson, II, p. 393, n. 3.

${ }^{4}$ Ibid., III, 93. In view of the fact that Herodotus visited Babylonia during the reign of Artaxerxes I, his statement on this point may be accepted as strictly historical.

5 Ed. Meyer (G.A., III, p. 4I) thinks that there were also Persian eunuchs. It is possible that by way of punishing officials or even common people, their children were condemned to be made eunuchs.

6 Herodotus I, I36. 
has survived in Persia to the present day. Sir Henry Rawlinson observes: "The greatest misfortune, indeed, that can befall a man in Persia is to be childless.' 7 Therefore it is unlikely that any Persian would have voluntarily offered one of his children to be made a eunuch. This class consisted, as a rule, of foreigners, who as Ed. Meyer points out, very often adopted Persian names. ${ }^{8}$ The statement of the Book of Daniel that the foreign boys who were made eunuchs at the court of Nebuchadnezzar were taught the learning and the tongue of the Chaldears, and were given Chaldean names, ${ }^{9}$ merely records a general custom of antiquity, and it is very likely that the same custom prevailed among the Persians, so that the eunuchs were given not only Persian names but also a Persian education.

However, the Persians were not the only race who looked upon childlessness as a curse and disgrace. The same was true of the Semites. "What wilt thou give me, seeing that I am going childless', complained Abraham. ${ }^{10}$ To pass away childless is a punishment for certain kinds

7 In G. Rawlinson's Herodotus I. p. 214 , n. 8.

* G. A., III, p. 4 I.

${ }^{9}$ Daniel I. 4, 7. However, of the names mentioned there as being given to Daniel, Hananiah, Mishael, and Azariah, only the first Bclteshazzar seems to be a genuine Chaldean name, corresponding to cuneiform Balatishar-usur Protect the life of the king!' while the last name Abed-nego, if corrupted or intentionally changed from Abdi-Nabī . Servant of Nebo', Nould be properly West Semitic or Aramaic, and Shadrach and Meshach seem to contain the Persian hypocoristical affix $k t$, and if so are not Chaldean. As a inatter of $\mathrm{f}$ ict, the latter name Meshach seems to be identical with the Hebrew name, Mishacl presenting the abbreviation Misha with the attached suffix $k e$.

10 Gen. 15.2 . The imputation is, of course, that there is no compensation for a calamity of that kind. 
of incest. ${ }^{11}$ Childlessness being considered the greatest calamity, the exilic prophet comforts the eunuchs with the following words: 'Neither let the eunuch say: Behold, I am a dry tree. For thus saith the Lord concerning the eunuchs that keep My sabbaths, and choose the things that please Me, and hold fast by My covenant: Even unto them will I give in My house and within My walls a monument and a memorial better than sons and daughters; I will give them an everlasting memorial that shall not be cut off'.12 The practice of adoption defined by many laws in the Code of Hammurabi ${ }^{13}$ shows that the Babylonians as well as the Hebrews considered it a misfortune to be childless. And it is scarcely probable that this conception had undergone a change in the Neo-Babylonian period. Therefore, it is very unlikely that the Babylonians would have been willing to sacrifice annually five hundred boys to be made eunuchs.

The Jews who rejoiced at the downfall of the Babylonian empire, and wcre, of course, the most loyal subjects of the Persians, were naturally hated by the Babylonians. The tax-collectors, being most likely Babylonians, and not Persians, we may certainly assume that the Jews were forced to contribute a disproportionate share to the number of the boy-eunuchs. These victims, however, were not only not lost to the Jews, but were of the greatest benefit to them. Notwithstanding the Persian names and education they were given, they remained, as far as possible, either secretly or openly, adherents of the Jewish religion. It

11 Lev. 20. 20, $2 \mathrm{r}$.

12 Isa. 56. 3-5.

13 Code of Hammurabi, col. XVI, rev. 31 ; col. XVII, rev. 23. Abraham's complaint, 'one born in my house is to be mine heir' (Gen. $\mathbf{5}_{\mathbf{5}} \cdot \mathbf{3}$, is to be understood by way of adoption, which is in accordance with the Babylonian laws, but not with those of Israel. 
is very likely that they acted as the mediators between the Persians and the Jews. We may assume that most of the favours granted to the Jews by the Persian rulers were due to their influence. ${ }^{14}$ Some of them may have been leaders in Israel. Marquart's suggestion that Nehemiah could not have been cup-bearer of Artaxerxes, if he had not been a eunuch, ${ }^{15}$ is very reasonable. The fact that the exilic prophet considered it worth while to deliver a Divine message to the eunuchs leaves no room for doubt that this class was numerous, and did not consist of a few scattered individuals. 'The everlasting memorial', that the prophet promised them was scarcely the reward for their observance of the Jewish laws. They must have earned 'the everlasting memorial' in other ways. How could he have promised them 'a monument and a memorial in the house of the Lord, and within His walls', if they did not greatly contribute to the erection and existence of 'this house and these walls'?

The eunuchs were better acquainted with the minutest details at the court than any Persian and Greek. The Persian kings were always surrounded by eunuchs. ${ }^{16}$ Some

14 Ed. Meyer (G.A., III, p. 4I), states as follows: 'Among the eourt officials, the eunuchs played a great part. Many of them had been raised to highly confidential positions at the court, or were entrusted with important offices in the provinces. In the later period, under the rule of the favourites, they frequently exereised a decided and fatal influence on the policy of the empire'. Now seeing that the eunuchs as a rule were of foreign descent, we may certainly assume that the Jewish eunuchs were not less influential than others.

15 Fundamente, p. 36 . The faet that Nehemiah attended the king as butler in the presence of the queen (Neh. 2.6), leaves little room for doubt that he was a eunuch. Besides, the personal attendants of the Persian kings were, as a rule, eunuchs, and Nehemiah was most probably no exception.

${ }^{16}$ Even in the battle of Cunaxa we find Artaxerxes II and his brother 
eunuchs of Jewish origin nay have been present at the casting of the lots, at Haman's audience with the king, at his deliberations with his friends, \&c. There is no improbability involved in the assumption that the compilers of the Book of Esther did base the details of this narrative upon the testimony of eye-witnesses. ${ }^{17}$ The compiler may have been a eunuch himself who either in his youth was an eye-witness of these events or relied upon the testimony of fellow-eunuchs who were present. There were, no doubt, Greek eunuchs as well, ${ }^{18}$ and many notices concerning Persian events found in the works of Greek authors may have been derived from these eunuchs. However, the latter were indifferent to the events that occurred at the Persian court, if they did not have a special bearing upon Greek affairs, and upon other points their information could scarcely have been exact, while the Jewish eunuchs were deeply interested in events, involving the fate of their own people. Moreover, it is even questionable whether a strictly religious Jew who wrote for a religious purpose does not deserve more credence

Cyrus surrounded by eunuchs, as Satibarzanes, whom the king sent out to search for water, Mesabates, who cut off Cyrus' head and hand, Pariscas, the chief eunuch of Cyrus, and the eunuchs who were mourning over his body.

17 Cf. chapter IV. Paton, p. 213, finds no way of accounting for Mordecai's secret sources of information than by accepting the interpretation of the Targum : 'Through Elijah the high-priest'. Now it would be little short of arrogance on our part to insinuate that scholars who write commentaries on the Book of Esther are so little acquainted with Persian history as not to know of the important part the eunuchs played in that period. But it is due to the fact that the modern commentators regard our narrative as a romance written in the sccond century B.C.E., and for this reason do not consider it probable that the author had a proper knowledge of Persian customs and institutions.

18 Herodotus VI, $3^{2}$. 
than a Greek eunuch who recounts harem-stories for the diversion of some Greek traveller. The eunuch Hathach who acted as messenger between Esther and Mordecai was no doubt a Jew, and so was the cunuch Harbonah who informed the king of the gallows erected for Mordecai. They had, of course, to conceal their Jewish religion, as most of them did, especially in that period, but were nevertheless devoted to the Jewish cause. Thus it is seen that there is no historical improbability involved in assuming that Mordecai's knowledge of the circumstances at the issuing of Haman's decree was due to reliable sources of information.

The messages that were exchanged between Mordecai and Esther seem to indicate that the latter was more concerned for her own safety than at the calamity of the Jews. IVe cannot reproach her for her point of view. Mordecai lived in the midst of his people. Sceing continually their misery, his heart softened, and his indifference to the Jewish religion gradually melted away. Esther, however, was in a different position. Having been brought up in a lax religious spirit, her elevation to the rank of a queen, and the separation from her own people, could not have improved her religious principles. In the seclusion of the harem, only rumours of Jewish persecutions reached her, which could not make upon her so deep an impression as upon Mordecai who saw these persecutions with his own eyes. Furthermore, we must consider that Esther was now confronted with a most difficult task. She could not intercede with the ling on behalf of the Jews, without confessing her origin. In pretending to be a Persian woman, she had obtained her rank under false pretences. If she had been certain that the king was still deeply in 
love with her, the fact that she had concealed her origin might have been a matter of little apprehension, as 'love covereth all sins'. The fact, however, that the king could bear the separation from her for thirty days, might have been taken as a sure sign that his love was on the wane, ${ }^{19}$ and that some other lady of the harem had attracted his fancy. Therefore, Esther's reluctance to accede to Mordecai's request is no proof of a callous disposition, and does not impugn her character. She hesitated to expose her position and, perhaps her life, for the cause of her people, without being convinced of her ability to help them.

On being informed of her cousin's strange conduct, Esther rightly guessed that it must have been caused by some unprecedented calamity of the Jews, ' and exceedingly writhed in anxiety'. Mordecai's policy of concealing his connexion with the Jewish people, and especially after her elevation, for the purpose of guaranteeing her safety, was well known to her. But the fact that Mordecai acted in so sensational a manner was a sure indication of some unforeseen occurrence that left him no choice but to identify himself with his persecuted brethren. This being the case, Esther now became apprehensive for her own person. She correctly assumed that she would be called upon to intercede with the king for her people and thus be forced to reveal her own origin and religion.

It is not without reason that Esther did not ask for any explanation, on being informed of Mordecai's strange conduct, but merely 'sent raiment to clothe Mordecai, and

19 Keil, p. 639, likewise suggests that Esther thought that she was not in special favour with the king for the reason of not having been summoned to him for thirty days.

H. 
to take his sackcloth from off him'. She did this for the purpose of enabling him to enter the king's court, where her messenger might confer with him secretly and not in the presence of all the people-not, however, 'for the purpose of communicating with him personally'. ${ }^{20}$ Esther was still inclined to continue as long as possible the old policy of concealing her origin and religion. Mordecai, however, desired just the contrary, that Esther should imitate his example and throw off her disguise. Her intercession with the king being now the only hope of the Jews, he insisted upon staking her position and even her life for the achievement of their deliverance. Therefore Mordecai refused to accept the raiment sent by Esther, by this refusal plainly indicating his unconcern at endangering her position by his conduct.

Esther 4.

'Then called Esther for Hathach, one of the king's 5-9. eunuchs, whom he had appointed to attend upon her, and charged him to go to Mordecai, to know what this was, and why it was'. Thereupon Mordecai informed this messenger, in the first place, of his personal affairs, ' of all that had happened unto him'. He explained to him the reason that had forced him to reveal his identity. From

20 This is the interpretation of Siegfried, p. 156 , Wildeboer, p. 186 , and the same view is held by Paton, p. 217 , who observes: 'The author assumes that Mordecai could hold an interview with Esther, provided that he were properly dressed'. This, however, is decidedly wrong. Our author knew Oriental customs better than to assume anything of that sort. Otanes could not communicate with his own daughter Phaedima personally, as we know from Herodotus III, 68-69. Moreover, if the sackcloth was the only hindrance to a personal interview with Esther, why did not Mordecai accept the raiment that Esther sent him? He surely could not have been so unreasonably stubborn in that respect to let the chance of a personal interview with Esther pass on account of the sackcloth that he was wearing as a sign of mourning. 
the fact that Esther had no previous knowledge of Mordecai's contact with Haman we may conclude that they had not been in communication for a considerable time. ${ }^{21}$ Mordecai further informed Hathach of 'the exact sum of the money that Haman had promised to pay to the king's treasuries for the Jews, to destroy them'. Now this fact Mordecai could not have learned from the decree. The offer of Haman being a private matter between himself and the king, and furthermore being renounced by the latter, in saying 'the silver is given to thee', could not have been mentioned in the decree. This supports our contention that Mordecai had been informed of the circumstances at the issuing of the decree by one of the Jewish eunuchs who was present at Haman's accusation of the Jews and thus knew of this offer. The latter offer, Haman's willingness to indemnify the royal treasury for the loss it would sustain by leaving the property of the Jews to the Gentiles who would be willing to execute the royal decree, made the condition of the Jews wellnigh hopeless, as was pointed out in the preceding chapter. Their property given to the Gentiles, they could nowhere reckon upon their assistance. In informing Esther of Haman's offer, Mordecai's intention was to impress upon her mind the utter hopelessness of her people's condition. Otherwise, Esther might have comforted herself with the thought that the population would neither permit nor be a party to the execution of so inhuman a decree, or that the king would not be indifferent to the loss of the royal treasury and would repeal the decree. Finally, Mordecai

21 This would bear out our contention that Mordecai could not communicate with Esther except by means of her confidential cunuchs, when he occasionally saw one of them. 
handed over to Hathach 'the copy of the writing of the decree that was given out in Shushan to destroy them, to show it unto Esther, and to declare it unto her'. This was not done for the purpose of convincing Esther of the actuality of the danger impending over the Jews, but for another reason. There must have been, as we shall further see, a special decree for the capital of the empire which was more severe than that given out for the provinces. ${ }^{22}$

Esther 4. However, notwithstanding the urgency of Mordecai's 10-12. request and the knowledge of all these facts, Esther was not willing to comply with his entreaties: 'That she should go in unto the king, to make supplication unto him, and to make request before him, for her people'. She explained that there were two reasons that prevented her from undertaking this task. On the one hand, it was impossible to enter the royal inner court without being expressly summoned by the king, and, on the other hand, the supplication to the king would be of no avail in having the desired effect, as apparently the king no longer cared for her, since he could stay away from her for a period of thirty days. However, notwithstanding these drawbacks which did not augur well for the success of her petition, Mordecai still insisted upon her intercession with the king. From his own point of view, Mordecai had to insist upon his demand.

להגיר לה 22 See chapter IX. Paton, p. 218, is wrong in translating 'and to explain to her', and suggesting that Esther was unable to read Persian, so that Hathach had to both hand over the decree to Esther and to interpret to her its contents. Paton evidently overlooked the fact that Hathach was charged with a twofold message, firstly to show her the decree, and secondly to repeat to her Mordecai's report concerning his own experiences with Haman and the money that the latter had offered the king, and if so, our author could not have expressed himself differently : 'The copy of the decree.... to show it unto Esther and to report to her' the other matters. Thus ליגר לוגיר מרדבי refers to. 
Esther's supplication was the last and only hope of the Jews, though under the circumstances pointed out by her, her success in prevailing upon the king to avert the danger impending over them was somewhat questionable. Nevertheless, Esther's refusal to accede to Mordecai's demand was not without justification either. The proverbial saying, a drowning man will catch at a straw, may be true. But we ought to consider that, if the straw had a mind of its own, it would certainly refuse to be caught at and drawn down. Being convinced of the futility of her attempt at saving her people, Esther rightly refused to expose and sacrifice herself in vain.

Seeing Esther determined on not incurring any danger unless sure of attaining her purpose, Mordecai saw no Esther 4. I3-I 4 . other course but to force her to that step by threats, saying: 'Think not with thyself that thou shalt escape in the king's house, more than all the Jews. For if thou altogether holdest thy peace at this time, then will relief and deliverance arise to the Jews from another place, but thou and thy father's house will perish'. By these words, Mordecai meant to imply that by holding aloof from her people, Esther would not escape the fate she feared by interceding for them. Seeing no means of preserving their religion, the Jews would, of course, for the time being, be compelled to abandon it, rather than sacrifice their existence for its sake, and would hope for a change in government or in its policy, when they could avow it again.Most of the Jews did the same under similar circumstances at the time of Antiochus Epiphanes.-In this way, they would be saved, without her intercession. But, having been forsaken by her in the hour of their despair, the Jews would certainly avenge thomselves, and reveal to the king 
the deception practised upon him. Then she and her accomplices in this fraud, 'her father's house', namely Mordecai himself and his family, would lose their lives. ${ }^{23}$ Consequently, it would be less dangerous to confess freely her deception, and to throw herself on the king's mercy. In order to encourage her, Mordecai suggested the possibility that she might have been providentially raised to this exalted position for the purpose of saving her people in this emergency, saying: 'and who knoweth whether thou art not come to royal estate for such a time as this?' The sceptical expression 'who knoweth' (מי יודע), is quite in keeping with Mordecai's character as outlined above. He does not seem to trust implicitly in Providence, or perhaps doubts the justice of the Jewish cause.

Esther 4. Being impressed with Mordecai's argument, that the 15-16. refusal to endanger herself by revealing her origin and religion, for the sake of her people, would inevitably lead to her destruction, Esther chose the lesser evil, in following Mordecai's advice, saying: 'If I perish, I perish', in any case (וביאישר אבדתי אבדתי). However, she did not believe in the advisability of this step and despaired of the success of her mission. Now religion is the last refuge in despair, even among people of sceptical disposition. Esther was in this respect no exception, saying: 'Go, gather together all

23 Mordecai scarcely referred to a special divine judgement inflicted upon her for neglecting her duty toward her people, since her father's house could not be punished on account of her wrongs. Siegfried, p. 158, is ועתה את ובית ומבת now, however, thou and thy father's house will perish with the Jews '. He seems to have overlooked Mordecai's observation that ' then will relief and dcliverance arise to the Jews from another place'. As to his remark, why no allowance is made for the possibility that the king will make an exception in Esther's favour, it rests on the current interpretation that Haman's decree aimed at the destruction of the Jewish race. 
the Jews that are present in Shushan, and fast ye for me, and neither eat nor drink three days, night or day; I also and my maidene will fast in like manner.' Esther in imposing fasting upon her maidens, of course, refers to those of Jewish origin. ${ }^{24}$

Esther's action as described in the opening verses of the fifth chapter, seems incomprehensible. There does Esther 5 . I-3. not seem to be any valid reason why Esther should have gone to the king without being summoned, and should thus have exposed herself to the danger of being killed on the spot, in which case she would have been of no further use to the Jews, and her sacrifice would have been in vain. Was there no way of requesting an audience of the king? Surely the king was not so unapproachable that no message could reach him! However, after due consideration, we cannot but approve of Esther's action. Her acting in that way was dictated by a psychological reason. She assumed, as seen above, that the king was no longer in love with her, and that one of the other ladies of the harem enjoyed his favour. Now it is one of the most unpleasant tasks for a man who has been in love with a woman to inform her that he does not care for her any longer. He would rather

${ }_{24}$ Among the maids at the court were also some of Jewish origin whom Esther had chosen for her spccial attendants, as she could rely upon them not to betray her origin. There is no reason why Esther could not have chosen among the girls of Susa those who were to her liking, and naturally those of Jewish origin. Paton, however, prefers an interpretation that is absolutely improbable, in observing: 'Although the maids given by Hègai must have been heathen, yet Esther values the help of their fasting; and they are loyal enough to her to be willing to undertake it'. But does it stand to reason that Esther was forced to keep those seven maidens whom Hëgai had given her five years before that event and before the king had chosen her as successor to Vashti, and thus was limited exactly to the number of seven and was not permitted as queen to enlarge her household? 
go to any extent to avoid her than to meet her and tell her the truth frankly. In this respect there is no difference between a king and a common man. Human nature always remains the same. Herodotus tells us that when Xerxes fell in love with his niece Araynta, he dreaded Amestris who might detect his love. ${ }^{25}$ Artaxerxes II was in this respect not different from Xerxes. If Esther had requested an audience of the king, the latter might, to avoid facing her, have given an evasive answer, on the plea of being too much occupied with affairs of state. Even if the king should grant her an audience, being prepared for her coming, and having time for reflection, he might not be greatly impressed with her appearance. In this case, her confession, that she did not have a right to her exalted position, might give the king a just cause and the best chance of getting rid of her. Therefore, Esther resolved upon taking the king by surprise. Coming unawares upon him, she hoped-perhaps against hope-that her unequalled beauty would re-awaken his passion for her. Considering it from this point of view, we must admit that Esther was a clever woman, and displayed in this stratagem more sagacity and better knowledge of human nature than modern critics who see in this part of the story a defect of composition. ${ }^{26}$

However, even if the preliminary step turned out favourably, as Esther had expected, the intercession itself was nevertheless an extremely delicate problem that had

${ }^{25}$ Herodotus IX, 109.

${ }^{26}$ See Wildeboer, Siegfried, Paton, and others who refer to Herodotus III, $72,77,84$, I 8 , I40, who states that people might send in a message to the king and request an audience. Paton especially observes: 'Either the author does not know Persian custom, or he intentionally suppresses his knowledge in order to make Esther's going to the king more heroic ' (p. 220). 
to be handled very cautiously. Esther was well acquainted with the weak side of the king's character, knowing that he was capricious and easily accessible to personal influences. Though in her company, the king would be completely under her influence and willingly grant her request, out of her sight, in the presence of the prime minister, whom he would consult on that matter before giving a final decision, he would yield to the minister's influence. Furthermore, Haman could not but suspect that the disrespect of the queen's relative toward his person was not without her approval. Consequently, Haman was on his guard against her. But, at the same time, he was careful that none of his actions should give her any cause for intrigue, and therefore, as seen above, hesitated to punish Mordecai for his disrespect toward him, though legally he was justified in doing so. But if Haman should get information of Esther taking the part of the Jews and belonging to the same creed, his suspicion would be turned into a certainty. In this case, retreat was impossible for him. An open war between the queen and himself, similar to that between Parysatis and Tissaphernes, ${ }^{27}$ would have been unavoidable. By his influence, he might frustrate her attempts to meddle with the affairs of the empire. Furthermore, he might impress upon the mind of the king that his authority was at stake, if it should be known among the people that the chief wife of the king was a woman of Jewish origin. Considering the king's weak and vacillating nature, the outcome of such a combat was uncertain. Therefore, Esther resolved upon disarming Haman's suspicions by pretending the highest esteem and friendship for his person. And by matching her influence 
against that of the prime minister, she aimed at bringing about his downfall in her presence.

Esther 5. Seeing Esther coming to him uninvited and thus 3-5. exposing herself to the danger of being killed on the spot, the king naturally assumed that it must be a matter of high importance, demanding immediate attention that impelled her so to act, and therefore inquired into the cause of the matter: 'What wilt thou, queen Esther? for whatever thy request, even to the half of the kingdom, it shall be given thee'. Strange as it might seem, Esther's request was extremely modest. In reply to the king's extravagant offer: "If it seem good unto the king, let the king and Haman come this day unto the banquet that I have prepared for him'. Was the king not amazed at her answer that she had exposed her life for the purpose of inviting him personally to a banquet? No! As we know from Herodotus quoted above, it being the general practice of the Persians to deliberate upon affairs of weight, when they were drunk, Esther in accordance with the Persian custom prepared a drinking bout for the consideration of an affair of high importance. Now Haman, of course, had among the eunuchs his friends or spies who supplied him with information of all the happenings at the court. Esther's invitation could not be kept a secret either. If he were informed of this affair, Haman might have surmised the nature of the intrigue. In order to show that she had no secrets from him, Esther requested the king that the prime minister should be present at the deliberation. His presence at the banquet was quite in order, seeing that the deliberation concerned affairs of state, and this part of her request was no surprise to the king. It was probably not the first time that Haman had 
been admitted to the king's table to dine with the queen. Plutarch states that, at the time of Stateira, Artaxerxes II did that honour to two of his brothers. ${ }^{28}$ Therefore we may well assume that the king did the same honour to the prime minister 'whose seat was set above all the princes'.

However, Esther did not underestimate the prime Esther 5 . minister's sagacity, and there might still have lingered ${ }^{6-13}$. in his mind some suspicion that the queen's invitation was merely a trap to cause his downfall unexpectedly. Though it was unlikely that Haman should still entertain any suspicion of her disposition toward his person, Esther did not want to take any chance, and therefore pretended that her mind was not yet fully made up concerning the request to be deliberated upon, and again invited both the king and Haman to another banquet for the next day. This second invitation left no doubt in Haman's mind that he

28 Plutarch, Artaxerxes, V, 5. Even without reference to Plutarch, it would seem highly improbable that the king should not have been able to deliberate with his own chief councillor in the presence of his own wife. But it is rather strange that none of the modern commentators, who presumably investigated all the historical sources bearing on this subject and to whom Herodotus' description of Persian customs could scarcely have been unknown, can find a plausible reason for Esther's request: "let the king and Haman come this day unto the banquet that I have prepared for him', instead of asking for the life of the Jews. Nor do they explain the reason why Haman should have been invited with the king. They believe that the true reason is purely literary: 'The author needs time for the humiliation of Haman and the exaltation of Mordecai before the final blow falls'. Did the statement of Herodotus with regard to the customs of the Persians that 'it is also their general practice to deliberate upon affairs of weight when they are drunk * escape their mind? If not, did it never occur to them that Herodotus' statement applies exactly to the case under consideration which had to be deliberated under the influence of wine, and that it was natural that the grand vizier should be present at the deliberation which concerned an affair of state? See, however, note i 7 . 
was a great favourite with the queen, and he now became fully convinced that she had not the least regard for her relative. He might even have concluded that the queen's very intention of showing him this great honour was for the purpose of impressing upon his mind that she had been no party to the disrespectful conduct of her cousin toward his person, and that she heartily condemned his behaviour. Thus, any fear that she might avenge his just punishment was dispelled. Nothing now stood in the way of meting out the penalty to the wilful offender against the king's command.

On coming home, Haman called for his friends, his favourite wife, and numerous sons, who were high officials, and laid the matter before them, informing them how secure now his position was. Though he had been exalted above all grandees, nevertheless he did not feel quite at his ease, secing the disrespect shown to him by the queen's relative, and being afraid that it was done with her knowledge. To punish him as he deserved was not without danger. Now, however, the circumstances were different. There was no need for him any longer to combat the influence of the harem. Being a favourite of the qucen, he could use also her influence with the king for his purposes.

Esther 5. These reasons seeming plausible enough, the consensus I4. of Haman's advisers was, not to put up any longer with Mordecai's impertinence, and not to defer his punishment for flagrantly flaunting the king's command, saying: 'Let a gallows be made of fifty cubits high, and in the morning speak thou unto the king that Mordecai may be hanged thereon'. Critics consider the statement that the gallows prepared for Mordecai was fifty cubits high an exaggeration, 
and it has been suggested to read 'five cubits' (אמות), instead of 'fifty cubits'. ${ }^{29}$ This suggestion, however, is gratuitous. Our author certainly knew the usual height of gallows in the Orient better than all the commentators. If his intention had been to indicate that the gallows Haman erected was of the usual height, there would have been no need to inform us how high it was. But the actual existence of exaggerations in our story is undeniable, and we have seen that they are not original but additions of a later period, and the same may be true of the statement concerning the height of the gallows. However, while in our passage this statement may be out of place, and was perhaps taken over from 7.9 , there is no reason to doubt its truth, that Haman actually erected a gallows fifty cubits high for the purpose of punishing Mordecai in a spectacular manner. Mordecai's offence could not but arouse publicity, and therefore his punishment should fit the crime. Furthermore, it might prove a warning to the Jews to part with their creed and convince them of the hopelessness of their condition, seeing that even the queen's relative could not escape his fate in his encounter with the author of the decree. Finally, such a public execution would impress upon the mind of the population the firm position of the prime minister, so that none would dare to interfere with his decree and prevent its execution. For those reasons Haman erected the gallows on some high structure, so that everybody could see it.

Haman's downfall could have been effected without the incident described in the sixth chapter, which shows how Mordecai was unexpectedly honoured. This incident is

${ }^{29}$ Haupt (Purim, p. 6) observes that he would be inclined to make this suggestion, if the story were not fictitious. 
admittedly highly impressive, as it shows a singular instance of the irony of fate. The man for whom Haman erected the highest gallows, received at his own hands the highest honours. But, after all, this is merely an incident, and not a necessary link in the chain of natural circumstances. If the story were fiction we might see in the insertion of this incident a slight defect of composition. The dramatic effect and the contrast would have been more impressive if Haman had been overthrown at the height of his power and ambition. Owing to this incident, however, Haman's humiliation foreshadows his downfall, and the reader is prepared to see his final doom. Yet our author is by no means averse to dramatic effects to impress the mind of the reader. His story is construed according to the laws of cause and effect. None of his sentences, as far as original, are superfluous or illogical. However, fact is proverbially stranger than fiction. Our author records an historical event, and was not a writer of fiction, and thus could do nothing against facts. The incident of the sixth chapter actually did occur, and also greatly contributed to cause Haman's downfall.

Esther 6. While Haman was busy at home preparing the gallows I-3. for Mordecai, and anticipating the satisfaction of revenge on his adversary, a trivial incident occurred at the court that frustrated his intention and was the cause of his own humiliation. 'On that night could not the king sleep; and he commanded to bring the book of the records of the chronicles ${ }^{30}$; and they were read before the king. And

30 Paton, p. 244, remarks : 'This is not a natural way to pass a sleepless night; with his numerous wives, the king might have found something livelier'. But this is rather a naive observation. An oriental king may sometimes become sick and tired of his numerous wives and not care for the pleasures of the harem. 
it was found written that Mordecai had told of Bigthana and Teresh, two of the king's eunuchs, of those that kept the door, who had sought to lay hands on the king Ahasuerus.' We may assume that it was that part of the chronicles wherein his personal affairs were recorded, ${ }^{31}$ and therefore it was quite natural that also the deed of Mordecai who had revealed the conspiracy of the chamberlains against the life of the king was mentioned therein. Now it is scarcely probable that the deed of Mordecai was merely mentioned incidently among the other events. But it is more likely that a Jewish eunuch played the part of Providence in that incident, ${ }^{32}$ and intentionally read Mordecai's deed before the king, as the latter in his bedchamber was undoubtedly surrounded by eunuchs, and not by other courtiers. On being informed of Mordecai's deed, the king inquired: "What honour and dignity hath

31 Mordecai's deed, as we are distinctly told, 'was written in the book of the chronicles before the king ' (Esther 2. 23). The peculiar expression 'before the king' indicates that this 'book' was reserved for the private use of the king and thus was kept in his apartments and not in the archives. This clause would thus indicate that there were other Persian annals of a general character. We may well assume that the king was especially interested in matters concerning his own person and kept a record of them for future reference. Hence 'the book of records' formed a special division of 'the chronicles', and is thus identical with 'the book of the chronicles before the king'. If so, ספר הוכרונות דברי הימים is to be rendered 'the book of the records of the chronicles'. Haupt (Critical Notes, p. I6I), however, sees in רברי הימים a gloss. But then, it must have been added to the text before its rendering into Greek, as the Greek version has $\mu \nu \eta \mu \dot{u} \sigma v^{\prime} a \tau \hat{\omega} \nu$ $\dot{\eta} \mu \epsilon \rho \hat{\omega} \nu$.

${ }^{32}$ Paton, p. 245, permits himself the philosophical observation: 'This is the way that things happen in 'story-books not in real life'. However, taking into consideration the important part that eunuchs played in that period, this miracle can find a rational explanation, since the Jewish cunuchs may well have played the part of Providence in this incident. See, however, note i 7 . 
been done to Mordecai for this?' Then said the king's servants that ministered unto him: "There is nothing done for him'. The answer was correct. The king did not ask whether any reward had been offered to him for this deed, and the servants probably could not have said anything about it. They knew only of the fact that Mordecai was still in the same position as before the conspiracy. However, we have seen that Mordecai might easily have obtained a high office on Esther's elevation, but had preferred to remain in obscurity, lest his identity should have become known, and for the same reason he could not but decline any reward offered him for having saved the king's life.

Esther 6.

The king was, of course, deeply hurt to perceive how 4-6. little his life was valued in the eyes of his ministers, that the man who had saved it had been left unrewarded. It was a point of honour with the Persian kings to reward magnificently those who conferred benefits on them. The omission in this case could be due only to the negligence of his prime minister. The latter ought to have known all meritorious persons in the empire, even those whose deeds dated back to a period before he had been placed at the head of the government, and ought to have recommended them for their due rewards. The neglect to do so was some indication that his loyalty to his sovereign was not so firm as he pretended it to be, and was evidently due to his personal ambition, being jealous of the merits of other men, and being afraid lest they should gain favour in the eyes of the king. He fully deserved, if not punishment, at least a lesson in modesty and self-abnegation, becoming a minister claiming to care only for the welfare of the empire. Reflections of this kind may have been, as events proved, in the mind of the king. 
The councillors used to come to the court early in the morning to be at the king's disposal. Thus it was in order that the king should inquire: 'Who is in the court?' as some or one of the councillors were sure to be there. But the author explains that the presence of the prime minister at the king's levee was only on rare occasions, and this time it was due to the fact of ' having come into the outer court of the king's house to speak unto the king to hang Mordecai on the gallows that he had prepared for him'. On being summoned into the inner court, the king asked him: "What shall be done unto the man whom the king delighteth to honour?' The question was, of course, a snare, and Haman was caught in it. This is seen from the fact of his not being told the name of the person for whom this honour was intended. This evidently indicates that the king did not trust him to be fair toward everybody. Recalling to his mind the honour shown to him by the queen the day before, Haman firmly believed that she had influenced the king in his favour to heap new honours upon him, and therefore said in his heart: "Whom would the king delight to honour besides myself?'

Of special significance for the incident under consideration is a story of Artaxerxes II narrated by Plutarch: 'One day as the king was hunting, Tiribazus showed him a rent in his robe; upon which the king said, "What shall I do with it?" "Put on another and give it to me", Tiribazus answered. "It shall be done so", said the king, "I give it to thee, but I charge thee not to wear it." Tiribazus, though not a bad man, was vain and giddy, and disregarding the restriction, soon put on the robe, at the same time tricking himself out with some golden trinkets fit only for queens. The court expressed great indignation, II. 
because it was a thing contrary to Persian laws and customs; but the king only laughed and said to Tiribazus : "I allow thee to wear the trinkets as a woman and the robe as a madman".' 33 We thus see that it must have been a rare distinction to wear apparel the king had worn.

Esther 6. This rare distinction of being arrayed with the apparel 7-II. which the king used to wear, Haman proposed for the man whom the king intended to honour. On hearing Haman's proposal, the king was now fully convinced of his prime minister's unbounded ambition, as it was obvious that the highest grandee of the empire could not have proposed an honour of this magnitude for any other man but himself. If reflections of the kind suggested above crossed his mind on the information that the man who saved his life remained unhonoured, the king was now more than ever resolved upon lowering Haman's pride, and to his amazement, commanded him to bestow personally the honours, he had proposed for himself, upon the man whom he was about to denounce to the king, and for whose execution he intended to request permission. Now the royal command to do this honour personally exceeded the proposal of Haman, as the latter was not merely 'one of the king's most noble princes', but the highest among them 'whose seat was set above all the princes'. If he had not intended to humble Haman's pride, the king would certainly have commanded one of the other grandees to bestow these

${ }^{33}$ Plutarch, Artaxerxes V, 3, 4. Now it might, indeed, have been against Persian customs to wear the garment of the king, and therefore it was a special distinction, since the king, as we have seen, was not restricted by any custom. Tiribazus, of course, did not have any claim to being distinguished in that way. Paton, p. 248 , also refers to the story of Plutarch, and remarks that from this it appears that to wear the king's own robe was accounted one of the greatest favours. 
honours upon Mordecai. Serving as page and herald to any other man was certainly not becoming the grand vizicr of the empire. But if the ling doubted his devotion, and was chagrined at his overbearing pride, Haman's proposal as amended by the king was the best course of teaching him modesty and justice toward everybody.

This incident, as narrated by the author of our story, involves no improbability, and there is no apparent reason why it should be discredited. However, this is far from being the current opinion of critics due to a term used here that seems to be out of place. Modern biblical commentators have a special predilection for textual emendations. Words or passages under consideration that do not square with their interpretations are frequently considered errors of copyists, and as such emended. Their interpretations and emendations may or may not be wrong, but the method they apply is certainly sound and justifiable, even from a strictly conservative point of view. The biblical text may have been inspired, but the copyists who handed it down were certainly not. The word of God was written down by honest, God-fearing men, but they were not infallible, and though they may have been careful and sagacious they were liable to commit errors like any other carcful writer. The Book of Esther, however, is treated differently from all other sacred writings. Though generally regarded inferior to the latter, and by most of the modern critics not looked upon as sacred narrative at all, nevertheless if this book contains words absolutely inconsistent with and contradictory to the story, the modern critics cling tenaciously to them, and do not ascribe such a palpable fact to errors of copyists, for the purpose of demonstrating that this story could not have happened. 
A striking instance of that kind may be seen in the fifth and sixth chapters of our story. On his return from the queen's banquet, and assembling his friends to deliberate with them on his position and Mordecai's punishment,

Esther 5. Haman states among others: "Yet all this availeth me I3. nothing, so long as I see Mordecai the Jew sitting at the king's gate'. Thus it is evident that Haman's friends were acquainted with the fact that Mordecai was a Jew. Nevertheless, after Haman's humiliation, and on recounting 'to all his friends every thing that had befallen him', Esther 6. the same friends told him: "If Mordecai be of the seed I3.

of the Jews, before whom thou hast begun to fall, thou shalt not prevail against him, but shalt surely fall before him'. Here, again, we see that Haman's friends before this incident had not known that Mordecai was a $\mathcal{F} c w$.

Esther 6. Furthermore, on Haman's proposal of the honours that Io. should be bestowed upon the man whom the king intended to honour, the king commanded him: 'Make haste, and take the apparel and the horse, as thou hast said, and do even so to Mordecai the Jcw, that sitteth at the king's gate'. Does it stand to reason that the king should have honoured a member of the people who had been accused of disloyalty, and whose extermination he had decreed a few days before that incident? ${ }^{34}$ This difficulty could find its solution only by means of the preposterous explanation that Ahasuerus had not known the name of the pcople whose extermination he had decreed. There is

24 So also Wildeboer and others. According to Haupt, Critical Notes, a considerable part of the Book of Esther, in the Massoretic text, and of ten even in cases where the latter agrees with the Greek version, consists of glosses, and thus there is no reason why the same should not be true of the term היהודי. 
no need for entering into a discussion of such an interpretation, as we have dealt already in the third chapter of our investigation with this impossible view. But there can be no doubt that those difficulties and improbabilities would automatically disappear, if we see in the term 'the Jew', in both places under consideration, a slip of the pen on the part of the copyists.

The name of Mordecai, in his lifetime, and also later, among the Jewish people, was 'Mordecai the Jew' (חרדכי (היהודי , perhaps, because Mordecai was an un-Jewish name, or for some other reason. It was pardonable on the part of the Jews to emphasize their connexion with the man who had occupied the highest position in the empire, whose exterior and conduct neither before nor after the event narrated in our story distinguished him as a member of the Jewish people. The present Jews do exactly the same, pointing out with special pride the Jewish descent of some high officials or renowned scholars, who on the point of religion have scarcely anything in common with Israel. The copyists were so used to this designation 'the Jew' (היהוד'), that they inserted it in wrong places. Ahasuerus had not the slightest notion of Mordecai's Jewish descent. It is not likely that Mordecai's fellowofficials, who had been a short time before apprised of this fact by Mordecai himself, should have hastened to the king to inform him of this important news. Siegfried ingeniously remarks: 'Mordecai's origin was, of course, recorded in the annals' ${ }^{35}$ But how could this fact have been recorded in the annals, seeing that Mordecai himsclf had made a secret of it? 'Could Ahasuerus have forgotten 
Mordecai's nationality?' commentators ask mockingly. ${ }^{36}$ No, he did not forget it, and he never knew it.

Esther 6. Haman's humiliation, as we remarked above, foreshadowed his downfall. He was a person of high intellect and sagacity, and at once perceived that the king intended to humiliate him. His prestige was gone. The population could not regard him any longer as the first man of the empire. If the king had intended to retain him in his office he would not have undermined his authority, as the king's power rests upon that of his representatives, entrusted with the reins of government, and his authority demands that his grand vizier should be generally respected. Therefore, Haman was afraid that his official career would soon be over.

On coming home humbled and dispirited, 'mourning and with covered head', and recounting to his friends everything that had befallen him, the latter confirmed his worst fears. If what they told Haman should be considered a prediction, which is, indeed, the consensus of opinion of the commentators, then this prediction must not be regarded as an historical fact, but merely as a legendary tradition. After an event has occurred, people always claim that it was predicted, according to the maxim: 'post hoc crgo propter hoc'. Especially in this case, 'the wise men' (חכפים), whom we may identify with the Magians, might have spread this tale among the people, after Mordecai succeeded Haman as prime minister, and prided themselves on the fact of having predicted Haman's downfall and Mordecai's elevation. However, this inter-

s6 This question had already been raised in the eighteenth century by J. D. Michaclis, and since then it is repeated by all critics, without perceiving the fundamental error of this question. 
pretation is far-fetched and unnecessary. The statement of Haman's friends was not a prediction but a foregone conclusion. It was reasonable to expect that Mordecai, after having been so magnificently honoured, should become one of the highest grandees of the empire. If Mordecai had not been a Jew, his high rank might have caused some concern to Haman, but would not necessarily have been detrimental to his position as prime minister. Both the latter and the new favourite might have lived upon the best terms, and shared the king's favour together. But owing to the fact that Mordecai was 'of the seed of the Jews', the latter and the prime minister were deadly enemies, and could not exist side by side. Considering that Mordecai was high in favour, and Haman's position was badly shaken, the outcome of their impending combat could easily be foreseen. ${ }^{37}$ However, after all, Haman's high position only was in danger, and not his life. He did not commit any crime that should have put his life in jeopardy. Nor does the prediction of his friends imply the loss of his head, as is generally understood by commentators.

We have mentioned above the letter of Cyrus the Younger to the Lacedaemonians, quoted by Plutarch in his 'Life of Artaxerxes', in which Cyrus boasts that he is able to drink more wine, and carry it better than his brother Artaxerxes. ${ }^{33}$ This statement is the key to the seventh chapter of the Book of Esther, and the only explanation of Haman's final downfall and execution. We

37 Paton is thus wrong in observing that 'It is hard to see why Haman's fricnds should find anything alarming in his sustaining a temporary reverse bcfore a Jew'.

${ }^{28}$ Sce chapter IV, note 35 . 
learn from Cyrus' letter that the Persians prided themselves on their drinking capacity, and considered it a great virtue to be able to consume large quantities of wine without becoming intoxicated. One incapable of performing such a feat was looked upon as a weak character: for a person of strong intellect is not easily overpowered by intoxicants. On the contrary, under their influence, the energies are roused, and the mental faculties stimulated. For that reason, the Persians deliberated upon weighty affairs under the influence of wine, as seen from Herodotus' statement quoted in the seventh chapter of this work. Tacitus asserts that the Germans did exactly the same. ${ }^{39}$ This letter shows further that Artaxerxes did not possess this quality, and was frequently overpowered by wine. There is not the least reason to doubt Cyrus' statement, as a Persian, and especially an Achaemenian prince, would not tell a falsehood. Cyrus evidently meant to indicate that Artaxerxes being a weak character, a treaty with such a king would be rather precarious. Being exceedingly vain, Artaxerxes would never have conceded that he was deficient in what the Persians considered a high quality. We may rest assured that at a convivium he indulged more in drink than his guests, and unable to stand it, became actually intoxicated. In such a condition he may have committed many an action that he never would have done had he been in his right senses. Woe, however, unto the man who would have had the temerity the next day to remind the king that he was too strongly affected by wine, and for this reason ought to reverse his decision. The fate of Prexaspes, who declared Cambyses to be greater than his father Cyrus the Great, with the exception 
of being too much given to wine, as Herodotus recounts, ${ }^{40}$ was a fair warning to the Persian courtiers not to allude to a wealiness in the king's character. If Artaxerxes did commit an imprudent action in a state of intoxication, he could not but approve of it the next day, as otherwise his weakness would have become known.

Dejected at his recent experience, and thrown into Esther 6 . a state of deep consternation, by the prediction of his friends, Haman was still seeking ways and means of extricating himself from his difficult position, and his inclination was so far from feasting, that he almost forgot the queen's invitation. He was not there in time. ${ }^{41}$ This was a breach of court etiquette. Fancy the king waiting for his guest ! This is what our author meant to indicate, saying: "While they were yet talking with him, came the king's eunuchs, and hastened to bring Haman unto the banquet that Esther had prepared.'

The downfall of Haman, notwithstanding the preceding Esther 7. I. incident, would scarcely have been effected, if the king had been drinking moderately, or, if under the influence of quantities of wine he had consumed, he would have been capable of reasoning clearly concerning the affairs of the empire. The deliverance of the Jews was apparently due to the defect in his character attributed to him by his brother Cyrus. He was actually at that time in a condition

${ }^{40}$ Herodotus III, 35 .

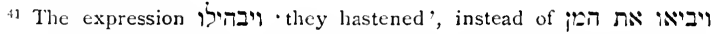
'they brought Haman', is not without reason, and evidently indicates that Haman had tarried too long at home. Paton, however, ignoring the real significance of the term, asserts that there is no suggestion that Haman in his grief had forgotten his appointment with Esther and the expression ' hastened' means no more than 'brought expeditiously'. This may perhaps be true of the English term, but certainly not of that of Hebrew. Our interpretation agrees with that of Wildeboer. 
of not being able, as it were, to tell Haman from Mordecai. Now we have seen, as Herodotus states, that the Persians were sometimes sober at their first deliberations. ${ }^{42}$ And - we have further pointed out that Haman's accusation of the Jews did not take place at a banquet, since the decision was apparently reconsidered under the influence of wine. ${ }^{43}$ Being fully convinced of the king's love for her, Esther had nothing to fear for her own person and position, and could frankly confess her origin to the king. If Haman had deceived the king, and his advice of destroying the Jews was due to pure malice, for the purpose of wreaking vengeance on Mordecai-as the Massoretic text indicates, and as accepted by all commentators-Esther could have caused his downfall in his presence, in a straightforward manner, when the king was capable of dealing with affairs of state, and not at a drinking feast. His action being outrageous, and nothing short of high treason, Haman would have lost his head at once. The king could never pardon such a crime of having used his authority for the extermination of a whole people, and having him branded as a cruel monarch, for the purpose of wreaking Haman's own revenge on a member of that people. However, the current interpretation is absolutely wrong. Haman in his accusation of the Jews did neither deceive the king, nor was his decree due to a private grudge against Mordecai. For this reason Esther was forced to take advantage of a moment when the king was not responsible for his actions, and had no other choice but to resort to the Persian custom of deliberating affairs of importance under the influence of drink, as only under such circumstances the downfall of the prime minister and the deliverance of

42 Herodotus I, I33.

${ }^{43}$ See chapter VII. 
the Jews might be effected. That drinking, for the purpose of a deliberation, was the only reason for Esther's banquet, may be further seen from the singular expression: 'And the king and Haman came to drink (לשתות) with Esther the queen'. The identical expression is used also in the third chapter, in the passage: 'the king and Haman sat down to drink', and we have seen that our author meant to indicate thereby, that Haman's decree was reconsidered under the influence of wine.

Drinking without discretion as usual, "the king said Esther 7 . again unto Esther on the second day at the banquet of wine: Whatever thy petition, queen Esther, it shall be granted thee; and whatever thy request, even to the half of the kingdom, it shall be performed. Then Esther the queen answered and said: If I have found favour in thy sight, $\mathrm{O}$ king, and if it please the king, let my life be given me at my petition and my people at my request; for we are sold, I and my people, to be destroyed ${ }^{44}$ (to be slain,

44 Though in the decrees of both Haman and Mordecai the superfluous synonyms להשמר להרוג ולאבר are doubtlessly later additions, there is good evidence for the assumption that here in Esther's accusation of Haman these terms are original. It is natural that Esther in her excitement should have strongly emphasized the danger impending over her people and for this reason used synonymous expressions. It is even probable that the late interpolators in inserting להישמר להרג into the decrees of Haman and Mordecai borrowed these terms from Esther's accusation. That these terms in the latter are original can be plainly seen from the fact that the Greek

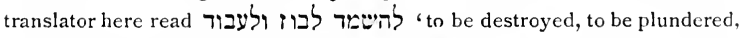
and to scrve', instead of להישמר להרוג ולאבר. To be sure, it is quite inconceivable that a Jewish translator should have misread לעבור לחרור 'to serve' for to be destroyed'. But this rendering may be taken as a further confirmation of our contention that the Greek translator did not possess a Hebrew copy of the Book of Esther, when he made his translation (sce chapter I, note 8). It is perhaps due to this error that the Greck text is here mixed up and totally corrupt in other respects, as far as its rendering 
and to perish). But if we had been sold for bondmen and bondwomen, I had held my peace, for the calamity would not be equal to the loss of the king (i. e. we would endure this calamity rather than that the king's revenues should suffer a loss) '.45 We notice here that Esther took good from the Hebrew is concerned. The term לעבוד did not seem to the

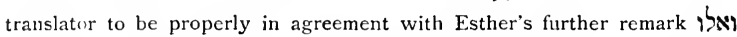
But if we had been sold for bondmen ואנו לעבדים ואים and we are sold for bondmen and bondwomen'. But

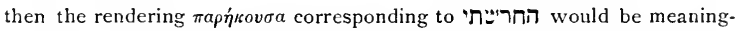
less in this connexion, unless the meaning of this passage would be: if לעבור should be our fate, I had held my peace. Further the rendering é $\pi \rho \dot{a} \theta \eta \mu \epsilon \nu$ does certainly not correspond to Hebrew

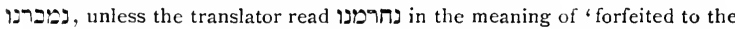
royal treasury'. Finally the translator seems to have read ' שוה בחצר המלך ' for the adversary is not fit for the royal court', if not

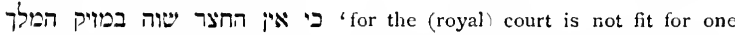
who causes damage to the king'. Errors of this kind would have been impossible, if the translator had not merely relied upon his momory, in rendering the story into Greek.

${ }^{45}$ The term 75 is with Ibn Ezra's commentary to be construcd as an abstract noun 'calamity'. All the attempts at construing it as a concrete noun, 'enemy', have failed. This clause must contain the reason for Esther's keeping silence. Cf. the discussion of the various interpretations of this passage in Paton's commentary, p. 26r. But Paton is certainly wrong in his objection to the construction of 7 " as "calamity, adversity', maintaining that it never has that meaning in Esther. $\Lambda \mathrm{s}$ a matter of fact, this term occurs only twice in our story, here and in and as to the latter, Paton and others failed to see that it actually means:

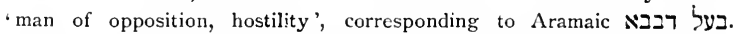
Haman is elsewhere not designated as ציר היהודים but as צורר היהודים.

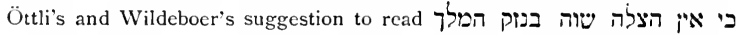
'for the deliverance is not worthy that the king should be endamaged', is thus an unnecessary emendation, though linguistically well possible, as the term הצלה actually occurs in our story (Esther 4. 14). Haupt (Critical Notes, p. 165) maintains that the term $\mathrm{Pr}$, which in the Bible occurs only here, does not mean 'damage', but 'annoyance'. But this term occurs innumerable times in the Mishnah,Talmud, and Nidrashim, where it certainly 
care not to mention the name of her people exposed to destruction, as otherwise it would have spoiled the effect. The king did not have the slightest notion of Esther's Jewish origin. Being intoxicated, his intellect was naturally obscured, and he could not divine that Esther alluded to the Jewish people. Hence, surprised that such an outrage should have been committed without his knowledge, the king demanded to know: "Who is he, and where is he. that durst presume in his heart to do so?' whoreupon Esther dramatically exclaimed: 'An adversary and an enemy, even this wicked Haman!' If Esther had mentioned in her petition the name of the Jews, the outcome might have been different.

The king was now incensed at the thought that events Esther 7.7. like that should happen in his empire, of which he had not the least information. But he was too vain to admit that his prime minister ventured to act without his knowledge. Haman being accused of a heinous crime, and having been designated by the queen as an adversary, an enemy, and a wicked man, the king could not discuss the matter with him amicably, as it would have been an insult to the queen. Her accusation may have added fuel to his suspicions that his prime minister was not the devoted servant he pretended to be. But the esteem for his high intellect had not yet gone, the scrvices he had rendered to the empire had to be considered, and therefore the king hesitated to blame him. On the other hand, the slight capacity of reasoning that the wine might still have left him, was

has no other meaning but 'damage'. Yet there is no reference in his arguments to this fact. As to his evidence from various Aramaic passages for his contention that the root pis means 'to annoy', it rests upon his own interpretation of these passages. 
blinded by his infatuation for the queen, and the king could not find any excuse for his prime minister. Thus vacillating, he did not answer, but ' arose in his wrath from the banquet of wine and went into the palace garden', evidently for the purpose of calming down before giving a final decision. ${ }^{46}$

Esther 7.8. Having been made acquainted with Mordecai's creed, before the decree was issued, Haman knew at once whom and what Esther meant by her accusation. Hearing the queen accusing him as a wicked person, and seeing the king in a condition of intoxication, incapable of reasoning, Haman naturally became terrified. To defend himself against this accusation was useless. Political reasons carry no weight with one who is not in a proper state of mind. His only hope was to gain time. The king in a condition of sobriety would, of course, listen to reason. Whether he would retain his position or be dismissed was of secondary consideration. Anyway he could convince the king of his innocence of the queen's accusation, as he could not have acted otherwise. The decree having been.issued with the king's consent after due investigation and deliberation, a justification of his action was unnecessary, and Haman could plead that he certainly could not be made responsible for the fact that the queen was a member of a people whose creed was inconsistent with the Persian laws. If his life had been spared only a few days, it is very questionable whether the Book of Esther would ever have. been written.

Therefore, to save himself for the moment: 'Haman stood up to make request for his life to Esther the queen;

46 So also Bertheau-Ryssel, Öttli, Siegfried, Haupt (Critical Notes, p. 168 . For the various interpretations see Paton, p. 262. 
for he saw that there was evil determined against him by the king.' Haman may have feared that the king was resolved upon destroying him, but he was wrong. The king's mind was far from being determined on this point. He was still wavering between his love for the queen and his esteem for the grand vizier. In his supplication to the queen, Haman may have promised her to revoke the dccree against the Jews in some way, if given a chance. Esther, however, was well aware of the fact that a delay of his final downfall might be fatal to her, and therefore turned a deaf ear to his supplication to stay the wrath of the king. ${ }^{47}$ In his despair and frenzy, Haman might easily have forgotten that it was a crime to touch the wife of the ling, as Plutarch informs us, ${ }^{4}$ and might have seized her hands, imploring her urgently to comply with his request. But Esther may have pushed him aside and thus he fell

${ }^{47}$ Paton (p. 262) is totally wrong in his reflections on this case, saying: 'It must be admitted that her character would have been more attractive, if she had shown pity toward a fallen foe. The author might have represented her as interceding for Haman, even if the king had not granted her request, but such an idea is far from his mind.' If Esther had done according to the advice of this commentator, our author would have had no occasion for writing the story of Esther. Haman would have succeeded in carrying out his designs against the Jews. He was not yet a fallen foe, and Esther's intercession would have saved his life, as he needed only a short respite to convince the king of the guilt of the Jews in their stubborn refusal to comply with the royal decree with regard to the worship of Anahita, and this he could have accomplished only when the king was in a sober state of unind. Our author recorded an historical event, and was not a writer of fiction, and therefore could not represent Esther as interceding for her enemy. But the real antecedents of the danger to the Jews in that period being unknown to the commentators, their conception of all incidents of our story is bound to be erroneous.

48 Plutarch, Artaxerxes, XXVII, I. 2: - For the barbarians are so extremely jealous of their women, that capital punishment is inflicted, not only on the man who speaks to or touches one of the king's concubincs, but also on him who passes or approaches their chariots on the road.' 
upon the couch on which she was reclining. ${ }^{49}$ On his return from the garden at the very moment, the king found Haman in that attitude, and exclaimed: 'Will he even force the queen before me in the house?' However, did the king really imagine that Haman had intended to make an indecent assault upon the queen? To touch the king's wife was a crime in itself, and the king in a state of intoxication, exaggerated Haman's misbehaviour.

This was a terrible accusation. Nevertheless, accusation and even commission of a crime does not mean condemnation. The Persian kings, as a rule, did not put any one to death for a single fault, as Herodotus informs us. ${ }^{50}$ If so, the clause ופני המן הפו cannot mean 'and they covered. Haman's face', because he was condemned to death, as generally explained. Nor can we accept the interpretation of this clause, that Haman's face was covered with shame. ${ }^{51}$

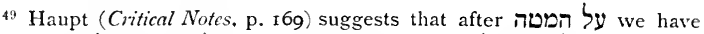

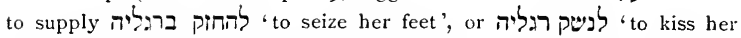
feet'. But, as far as the present writer can see, there is no single instance in antiquity that a male suppliant should have seized or kissed the feet of a queen, and an action of this kind would be contrary to all notions of decency and propriety among ancient Oriental nations. Thus, no matter whether our story be historical or fiction, and whether its composition belongs in the fourth century or in the Maccabean period, no author who had any knowledge of Oriental customs could have meant anything of this kind. Paton's remark, p. 263 , that 'falling down and laying hold of the feet was a common attitude of suppliants', is true only in case the person supplicated is a king, but not in that of a queen.

50 See chapter VII, note 27.

${ }^{51}$ So Siegfried. But a commentator of a book ought to be better acquainted with its contents; he observes: "Formerly Mordecai was "having his head covered", now Haman's head was covered". He cvidently forgot that Mordecai but of Haman. However, the current translation is linguistically scarcely possible, as the subject of $I E T$ is missing, and, furthcrmore, the

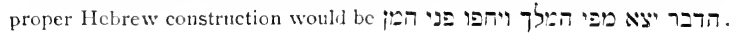


Haman was in mortal terror for his life, and the feeling of shame is psychologically inconsistent with that of terror. A more probable interpretation might be: 'Haman's facc was covered with pallor', i. e. Haman became deadly pale. However, there is another question to be considered. On hearing an accusation so terrible, and at the same time so ridiculous, how is it that Haman let this accusation pass without offering a defence? Why did he not protest his innocence, declaring that it was not his intention to assault the queen, but that he merely acted as suppliant? The violation of the Persian court-etiquette not to touch the king's wife was under such circumstances, if not pardonable, certainly at least not a heinous crime, for which he should undergo the penalty of death! Why did he not make any attempt to save his own life? Furthermore, when in addition the eunuch Harbonah accused him of having prepared a gallows for the man who had saved the king's life, why did Haman not defend himself against this accusation, by protesting that Mordecai's deed had been unknown to him, when he had intended to punish him as a criminal who had repeatedly and wilfully disregarded the king's command? No matter whether such a plea was true or not, an investigation of its truth would have delayed his execution. Regarding this point, we would be justified in objecting that events of this kind happen in story books, while in real life a man fights for his existence to the last ditch. If so, there would be no other way but to assume that Haman actually did defend himself; the defence, however, being of no avail, the author omitted any reference to it. But this would be a very forced interpretation. Now there is an Arabic phrase for 'falling in a swoon', or that literally means 'it was covered 
upon him', i. e. darkness came upon him. The question now arises, whether the clause פני המן חפו has not likewise the same meaning. If so, this clause would contain the explanation of Haman's strange conduct in not offering any defence against the accusations: (As the word went out of the ling's mouth), and Haman's face was covered, that is to say, he fainted.

Esther 7. Upon the king's exclamation: "Will he $c v e n$ force the 9-10. queen before me in the house?' (הגם לבבויט את המלכה עמי בבית), Harbonah, undoubtedly a Jewish eunuch, opportunely observed: Why this man is capable of committing the worst crimes; 'Behold, there is eicn a gallows which

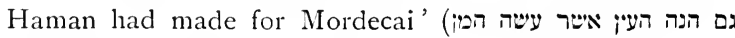
'למרדב. The ling could not but consider the intention of executing a man who had saved his life, and who for this deed had been on that very day greatly honoured, nothing short of high treason. Haman was now accused of a double crime, and according to the rule of the Persians in judicial matters, the king was justified in executing him at once. Otherwise, without Harbonah's accusation, Haman might have been arrested and brought before the judges 'that know law and judgement'. (ירעי דת וד'ין). In that case, Haman might, indeed, have proved his innocence, and perhaps regained his influence with the king. ${ }^{53}$ The

52 If Haman was already condemned to death, as it is generally interpreted, and Harbonah merely advised the nanner of his execution, the expression מעם הנה העין behold also the gallows' is rather strange. But it is different if the latter passage refers to the king's exclamation הגם לכבויט את ' המולבה הas as in this case Harbonah gives a second and more important reason for Haman's penalty of death.

53 We have already referred to the statement of Herodotus I, 137: "The king shall not put any one to death for a single fault. . . But in every case the services of the offender shall be set against his misdoings; and if the latter be found to outweigh the former, the aggrieved party shall then 
downfall of Haman was really effected by the Jewish eunuch Harbonah. ${ }^{54}$

From a purely Jewish point of view, the Jews would probably have completely disappeared from the face of the earth, if Haman had been permitted to carry out his decree, and his death was tantamount to their deliverance, no matter in what way it was contrived, and thus they are perfectly justified in making it the occasion of their annual celebration. But, leaving the Jews out of consideration, and considering his guilt from a purely Persian point of view, we cannot but judge that Haman fell a victim to the intemperance of Artaxerxes. There is a remarkable parallel between the fates of Haman and Tissaphernes, both grandees of Artaxerxes II. Tissaphernes had saved the king's life at the time of his consecration at Pasargadae. When Cyrus was gathering a large army with the intention of seizing the crown for himself, he went in person to Susa to inform the king of his designs. ${ }^{. j}$ At the battle of Cunaxa, he was judged the bravest man among all the Persian warriors in the royal army, and was honoured with princely gifts. The king bestowed upon him the hand of his own daughter, and considered him his most faithful friend, as Diodorus records. ${ }^{56}$ Being a Persian patriot, he naturally was the most implacable enemy of the Greeks, as Plutarch expresses himself. ${ }^{57}$ But neither his high proceed to punishment' (see chapter VII, note 27 ). The same would apply to the case of Haman. If placed before the judges, they might have found that Haman's services outweighed his misdoings, and thus might have acquitted him.

${ }^{64}$ Harbonah thus fully deserved his place in the Purim-Liturgy, in the blessing וגם הרבונה יזבור לטוב And also Harbonah may be remembered for good'.

\footnotetext{
55 Plutarch, Artaxcrxes VI, 6.

te Diodorus XIV, 5 .
}

67 Plutarch, Artaxerxes XXIII, I. 
position nor the royal favour could save him from the hatred of Parysatis, who never forgave him the part he had played against her favourite son Cyrus, and his death afforded to the Greeks great satisfaction, as Plutarch records. ${ }^{\text {is }}$ He lost his life on account of his policy against the interests of the Greeks. Nevertheless, his successor Tithrastes was compelled to pursue the same policy in the affairs of Asia Minor, as Ed. Meyer pointed out. ${ }^{59}$ Haman, as we have seen, was a Persian patriot. Perceiving the decay of the Persian empire, he aimed at infusing it with new vigour by reforming the Persian religion in accordance with the current religious conceptions, and imposing it as state religion on all subjects of the Persian empire. This innovation being successful, he was greatly honoured, 'and his seat was set above all the princes'. But due to this reformation, he became the most formidable and implacable enemy of the Jews. His reform was a deathblow to the Jewish creed, and either the latter or its adherents had to give way if its success should be complete. But his exalted position was powerless against Esther's influence with the king, and his downfall meant the preservation of Israel. . Yet the policy he initiated did not disappear with him. It was resumed again by Antiochus Epiphanes and the Sassanides, and became the standard policy of Christianity and Islam down to our times. Haman's decree itself seemed to have been resurrected under Artaxerxes III Ochus, as we shall further see. Thus, the historical judgement concerning the personality of Haman would differ if considered from a Persian point of view, instead of that of the Bible. However, if a nation should look upon historical events from the point of view

is Plutarch. Aitnacres. Ed. Neyer, G. A., V., p. 2 io. 
of other nations with which it comes into collision, and not regard its own welfare above all other considerations, it would have no right to existence. The Declaration of Independence of the American colonies was at the period of its promulgation a crime from a British point of view. The same holds true of all deeds, from immemorial times. by which nations gained their liberty. 


\section{CHAPTER IX}

The infallibility of kings-The forfeiture of Haman's property-The downfall of his whole family-The king being acquainted with the close relationship of Mordecai to Esther-His reflections upon Mordecai's modesty and Haman's ambition-The attitude of the people of Susa-The law concerning the worship of Anahita not being enforced-Its resurrection under Artaxerxes III Ochus-Haman's decree being still in force-Esther's pleaThe king's point of view-The sanguinary style of Mordecai's decreeThe interpolators - The decree in the Greek version-Its remarkable addition - Mordecai in the pomp of a prime minister-The joy of the people of SusaThe conversion of many Gentiles-The joy of the Jews for being given permission to defend themselves-The hope of their enemies to execute Haman's decree - The fight at Susa-The Jews being attacked on the second day-Haman's special decree for Susa-The exposing of the bodies of Haman's sons-The number of the slain Gentiles-The festival of PurimThe attitude of the Sopherim towards it-Its secular character and Persian features-Mordecai's letter of Purim-The 'Fast of Esther'-Mordecai's second letter of Purim-The opposition of the Sopherim-Purim a safeguard against Persian persecutions-The composition of the Book of Esther in a later period - The Persian annals - Mordecai's Persian name-His characterization by the author of the Book of Esther.

Esther8.r. Kings are infallible, and cannot be expected to admit having been in the wrong. This is especially true of Artaxerxes II, who was exceedingly vain, and would never have conceded that his reason had been obscured under the influence of wine. The execution of Haman, though ordered in a state of intoxication, was nevertheless approved of as an act of justice. The prime minister having been eliminated, the king was now completely under the influence of Esther. Being deeply in love with her, the king did not object to her origin.

The disgrace of a governor or other great men has always involved the forfeiture of their property to the 
crown. ${ }^{i}$ Haman having been condemned as a traitor, the king confiscated his estates and presented them to Esther, his accuser, as a mark of his favour. Haman's family and his sons, who apparently were high officials, ${ }^{2}$ were in all probability apprehended at the same time. This was in accordance with the Persian custom, as under the rulers of the Achacmenian dynasty the condemnation of a grandee involved his whole family. Intaphernes, one of the seven conspirators against Pseudo-Smerdis, when suspected of high treason against Darius, was arrested and executed with all his relatives, except his eldest son and the brother of his wife. ${ }^{3}$ Masistes, the brother of Xerxes, was slain with all his sons. ${ }^{4}$ Darius, the son of Artaxerxes II, was taken with all his children before the judges to answer for his crime, as Plutarch records. ${ }^{5}$ The same, of course,

1 See chapter VII, note 66.

2 There is scarcely any room for doubt that Haman's sons were grandees of the empire or high officials. If that had not been the case, their names would hardly have been mentioned. As a matter of fact, our author leaves no doubt on this point. The passage ויסבר להם הפץ את כבוד עשרו ורב בניו is surely not to be translated: 'And Haman recounted unto them the glory of his riches, and the multitude of his children,' as it is generally done, since his wife and friends were well acquainted with these facts. But ורב בניו ought to be translated 'the greatness of his children', and thus Haman told them not only of his own high position, but also of that of his children. The Greek translator, having been unable to understand the meaning of this expression, omitted it altogether (cf. chapter I, note 8). For 27 in the meaning of 'greatness', see Brown-Driver's Hebrew Lexicon, p. 9 I 4.

${ }^{3}$ Herodotus III, I I9. His eldest son was pardoned by Daritis, because his mother did not ask for the life of any of her children, but for that of her brother.

${ }^{4}$ Ibid., IX, I I3.

5 Plutarch, Artaxeries, XXIX, 8. The extermination of a family ot a traitor was more a matter of policy than for the sake of vengeance, as it was a foregone conclusion that the relations of such a man would not fail to avenge themselves if given an opportunity. The revenge of Prexaspes, whose son was murdered by Cambyses, almost overturned the $\Lambda$ chacmenian 
happened in the case of Haman, that his family had to share his fate. If Haman's sons had not been arrested at once, they would not have been eleven months later at Susa to be slain on the thirteenth of Adar. Under the reign of Darius II Notus, the father of Artaxerxes II, the entire family of Hydarnes was apprehended and delivered by that king to his queen Parysatis, that she might execute her revenge upon them for the injury done, or intended to be done, to her daughter Amestris, by Teriteuchmes, the son of Hydarnes, and Parysatis put them all to death, except Stateira. ${ }^{6}$ Exactly the same did Artaxerxes in delivering to Esther the family of Haman, the enemy of the Jews. By the term 'the house of Haman' (בית המשן) is thus to be understood not only Haman's property, but also his family.

The king learnt now for the first time of the close relationship between Mordecai and Esther, 'for Esther had told what he was unto her'. She evidently informed him of the fact that she was Mordecai's daughter, who brought her up when she had lost both parents in her childhood. If the author had intended to state that Esther informed the king of her relationship to Mordecai, a fact that formerly had been unknown to him, he would have used one of the

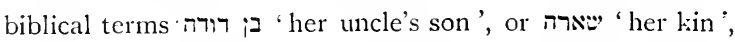
סיה הוא לה מרובה 'her relation', not the peculiar periphrase 'what he is to her'. The ling may or may not have known or remembered that Esther was related to Mordecai. If Esther on her elevation had procured for Mordecai a

dynasty, as the rise of Pseudo-Smerdis was due to him, who recognized him as the legitimate son of Cyrus, for the purpose of executing his vengeance upon Cambyses.

6 Ctesias, P'ers., 52-7. 
high position, his very existence would have recalled to the king's mind Mordecai's relationship to the queen. To be related to the king by marriage was not a rare distinction, as each of his three hundred and sixty wives had numerous relatives, though kinship to the chief wife may have been a greater honour; but the chicf wife had not always the greatest influence with the king. The latter could not be expected to recollect all the relations of his numerous wives. ${ }^{7}$ Moreover relationship is a mere accident, and bestowal of patronage on one's relatives, irrespective of their merit and legal claim, though customarily indulged in, is fundamentally immoral. Mordecai, however, was more than a mere relative of Esther, as the latter was indebted to him for a spontaneous act of generosity, in having acted as a father to her, an orphan. We may rest assured that Esther did not omit to impress upon the king's mind Mordecai's self-abnegation: How he might have obtained a high position on her elevation, yet preferred to remain in obscurity, even after he had saved the king's life, and did not claim any reward for having done his duty as a loyal subject. The king could not but be deeply moved by such unselfish behaviour, being so contrary to that of his courtiers who were always eager

7 If Mordecai had not saved the life of the king, his relationship to Esther would scarcely have procured him this high position. For if it had been customary with the Persian lings to bestow high positions upon the relatives of their favourite women, no other Persian would have had a chance to become a high official. Therefore, Wildeboer and other commentators are wrong in declaring 'Mordecai owed his promotion to his relationship to Esther; for his service to the king had already been rewarded'. The honour shown to Mordecai was certainly not, and could not have been, the final reward. What was the advantage of riding on the king's horse in royal apparel, if the recipient of this honour should afterwards remain in obscurity? The honour bestowed upen Mordecai was 
and clamouring for honours and distinctions. He might have contrasted Haman's pride with Mordecai's modesty. Like Alexander the Great who, in comparing Craterus with Hephaestion, said that Craterus was the king's friend, but Hephaestion was the friend of Alcxander. ${ }^{8}$ Artaxerxes might have said that Haman was the friend of the king, Mordecai, however, that of Artaxerxes. Now it is natural that the king should be eager to see a person of such a character, a rare specimen at a royal court, and accordingly 'Mordecai came before the king'.

Esther8.2. On seeing Mordecai, and being impressed with his personality and qualifications for an office of high responsibility, the king considered that a person of this character could be trusted implicitly, and would be eminently fitted for the office of the grand vizierate, now vacant, and therefore: 'The king took off his ring, which he had taken from Haman, and gave it unto Mordecai'. The latter was now installed in Haman's place. For the purpose of enabling him to conduct himself with the pomp and splendour of a grand vizier, ' Esther set Mordecai over the house of Haman', and Mordecai could thus freely dispose of its wealth for his private use. ${ }^{9}$ Mordecai had

similar to that bestowed upon Joseph by Pharaoh (Gen. 4r. 43), indicating his elevation to a high rank. This would have happened without the events narrated in the seventh chapter of our story. But in that case Mordecai would have had to contend against the influence of the grand vizier. Owing to these events, however, his competitor for influence with the king was removed.

8 Diodorus, XVII, I2.

9 Esther did not set Mordecai over the house of Haman, because it was a special honour for him to become manager of the queen's estates, as Wildeboer explains, since Mordecai had already attained the highest honour of a Persian subject, and we should think that a grand vizier had more important duties than to be the administrator of estates. With regard to 
been wealthy enough as a private man, but not as a minister.

To the population of Susa it was no surprise to see Mordecai in this high position. The man whom they saw being honoured in an unprecedented manner, to whom the prime minister himself had to serve in the position of a groom and herald, could not but become the highest grandee. $^{10}$ If the Caunian, who at the battle of Cunaxa, gave Artaxerxes a bottle of bad water, was raised by him from indigence and obscurity to honours and riches, as Plutarch records, ${ }^{11}$ should not the saviour of his life expect the highest reward? As for his being a Jew, this was a private matter, merely a religious opinion, that could be changed at any time. Furthermore, there was scarcely any perceptible difference between a Jew, neglecting the religious observances, and a strict Zoroastrian, since abomination of idols was characteristic of both of them. However, the elevation of Mordecai indicated a change in the policy of the empire. It meant that Artaxerxes intended to return to the policy of the old Achaemenian kings of not interfering with the creed of their subjects. The introduction of anthropomorphic images into the Zoroastrian religion, being in accordance with the sentiments of the people ${ }^{12}$ and a Persian law, was not, and could not have been, rescinded, but none was forced to worship them. After the ill-fought battle at Leuctra a large number of warriors belonging to powerful families fled from the

this point, Paton, p. 268, correctly observes that the administration of the estate and disposal of its revenues gave Mordecai wealth suitable to his new dignity.
10 See note 7 .
"Plutarch, Artaxerves, XIV, 2.
12. Cf. chapter VI. 
battle-field. For this cowardice they ought to have been declared infamous, according to the Lacedaemonian laws, but to put so rigid a law as this in execution, at a time when the offenders were so numerous, and when the commonwealth had so much need for warriors, was both impolitic and dangerous. The Lacedaemonians in this perplexity had recourse to Agesilaus, who advised them: 'Let the laws sleep that day!' The same was the case here. There was a law on the statute books of the Persians, but its observance was not enforced. Strict Zoroastrians might indeed have been well pleased with Mordecai's elevation. However, that law was not enforced as long as the Persian throne was occupied by a king who was favourably disposed towards the Jews. The banishment of many Jews to Hyrcania under the reign of Artaxerxes III Ochus, ${ }^{13}$ who succeeded his father Artaxerxes II, may indeed have been due to a resurrection of that law, as there is no plausible reason for the persecution of the Jews by this king. ${ }^{14}$ The population of Susa may have been neither surprised nor overjoyed at Mordecai's elevation. The term 'fear' (פחד) occurring three times in our story in reference to the attitude of the population, may perhaps indicate that the population submitted to

${ }^{13}$ Cf. Ed. Meyer, G. A., III, p. 212.

14 Graetz (History of the Jews, I, p. 408 ) is undoubtedly right in observing: "If this account may be considered historical, the banishment of the Judaeans must surely have been a mode of persecution inflictel upon them on account of their fidelity to their laws and their God; for it is hardly to be supposed that they took part in the revolt against Persia, which was then spreading from Egypt to Phoenicia.' This banishment of the Jews occurred after Persia's unsuccessful war against Egypt (36I-360), which incited Phoenicia to revolt against Egypt. About a year later, 359, Artaxerxes 11 died. Thus, it is very probable that the banishment of the Jews occurred at the beginning of the reign of Artaxerxes III. 
Mordecai's authority with a bad grace, out of fear. Howerer, even this is questionable, since this term may have a religious significance, as we shall see further.

However, though Haman had been executed, and his Esther 8. high position was occupied by Mordecai, the danger im$3^{-6 .}$ pending over the Jews by the former's decree was not yet averted. It has been emphasized that the most dangerous point of this decree consisted in the provision that permitted the people to keep for themselves the property of the slain Jews. ${ }^{15}$ The greed of the lower classes of the population could not be checked. Notwithstanding Mordecai's high position, undeterred by his power, the mob would certainly have executed Haman's decree to the letter, since none could be punished for complying with the king's command. For this reason, Esther now besought the king to reverse Haman's decree against the Jews. There were good reasons for justifying her request. It has been pointed out that the Jews, notwithstanding their stubborn resistance to the worship of Anahita, could rightly defend themselves against any accusation of disloyalty to the Persian empire. They were the only people in this empire who had always, from

15 See chapter VIl. Concerning Esther's request, Patoll, p. 269. observes: 'From verse 4 it appears that Esther once more risked her life in going to the king unsummoned. It is hard to see why this was necessary, now that Mordecai was grand vizier, and could bring all matters before the king. The author wishes to magnify Esther's patriotism by representing her as willing to risk her life for her nation.' This reflection would be somewhat plausible, if our author had expressed himself: 'And Esther came before the king; and the king held out to Esther the golden sceptre; so Esther drew near, and touched the top of the sceptre. Since. hovever, our passage distinctly states that the king held out to Esther the golden sceptre after she had addressed him, falling down before him and besceching him with tears to put away the mischicf of Haman. Paton: remark has not the least shadow of justification. Esther surely was not in danger of her life while lying at the king's feet and conversing with him. 
the time of their first coming in contact with the Persians, recognized and looked upon Ahuramazda as being identical with their own God. If the recognition of the Persian religion was a test of loyalty and a vital necessity for changing the heterogeneous subjects of the empire into loyal Persians, the Jews could justly claim to have become Persians more than a century before the reform of the Zoroastrian religion. This defence was incontrovertible, and was no doubt the main plea of the Jews during the persecutions. And we may rest assured that Esther did not fail to impress the king with this fact, and therefore could brand Haman's decree as 'an evil design against the Jews.' However, the worship of Anahita having been imposed on all subjects of the Persian empire, it is questionable whether this law could have been executed if the Jews had been granted the special privilege of being exempt from it, as was pointed out in the sixth chapter of this study.

Esther 8. Though impressed with Esther's plea and recognizing $7-8$. the injustice of Haman's decree, the king did not see any need for frustrating it. It is true that Haman's execution alone would have been no indication of a change in the policy of the government. Esther's origin was now well known, and seeing that Haman's house had been given to her, the pcople would know that Haman's downfall was due to his decree, and none would dare carry it out. ${ }^{16}$ This is what the king meant in saying: 'Behold, I have given Esther the house of Haman, and him they have hanged upon the gallows, because he laid his hands upon

16 No commentator suggests a reasonable explanation for the king's reply to Esther that he had given her the house of Haman, seeing that this fact does not seem to have any bearing upon the execution of Haman's decree. 
the Jews'. Now the latter statement is not exact, as Esther in her accusation of Haman did not mention the name of the people the latter intended to destroy. But the king evidently meant that the people would put this construction on Haman's execution. ${ }^{17}$ However, the king himself may have pretended this reason for justifying his hasty judgement. But kings, as a rule, are frequently deceived regarding the real sentiments of their subjects and their loyalty towards them. Artaxerxes likewise believed that the Persian people would be guided by his own attitude in this matter, and his change of policy. It may be assumed that Esther reminded the king that there might be people in his empire so little imbued with love and reverence for their sovereign, that they would follow their own inclinations, and would execute the decree, if they could do so with impunity. Thereupon, the king rejoined that, if Mordecai and Esther had some apprehension for the safety of the Jews, notwithstanding his own favourable attitude towards them, they themsclies might devise a plan ${ }^{18}$ by which Haman's decree might be frustrated, but not reversed, 'for the writing which is written

17 Haupt (Critical Not's, p. 172) considers the clause על איטר יהליה ידו ביהורים 'because he laid his hand upon the Jews', a gloss: ·for the king did not give the order: hang him thereon (תלוהו עליו, , because he had planned to exterminate the Jews, since this plan had been sanctioned by the king'. His observation is correct, and in full agreement with our own conception in the preceding chapter, that the king did not know that Esther in her accusation of Haman referred to the Jews. Nevertheless, we do not think that the passage under consideration is a gloss, since it is found also in the Greek version. See, however, chapter VIII, note 34 .

${ }_{18}$ The personal pronoun in connexion with an imperative occurs very seldom (e.g. Gen. 42. 16), and is used for some special emphasis, and also here וn is to be interpreted 'as for yourselves', that is to say, if you have any reason to fear for the safety of the Jews. Otherwise, we would expect ואתם תבתו. 
in the king's name, and sealed with the king's ring, may no man reverse'.

Esther 8. Mordecai's decree, as represented in our text, is quite 9-12. improbable. Its execution would have been a matter of impossibility. Though numerically representing an insignificant part of the population of the empire, the Jews could have defended themselves successfully against the attacks of their enemies with the assistance of their friendly neighbours, and the support of the officials. But they could not have enlisted the sympathy of the latter in their cause by committing atrocities in killing women, and especially little children, who did not and could not attack them. ${ }^{19}$ Even barbarians, as a rule, spared women and children. If the Jews had acted in such a cruel way, they would have been isolated in their defence, and thus certainly would have perished. We may credit Mordecai with so much good sense that he never decreed anything of that sort. The mere idea of contemplating cruelties of that kind would have exasperated all classes of the populations against the Jews. who were badly in need of their good will. Hence there is no room for doubt that the hands of interpolators were busy in making Mordecai's decree as formidable as possible, as already pointed out in the first chapter. Having exaggerated Haman's decree beyond all bounds, the interpolators did the same with that of Mordccai.

Now we have seen that there is good reason for the

${ }^{19}$ Haupt (Critical Notes, p. ${ }^{177}$ ) is wrong in justifying the inclusion of children in Mordecai's decrec on the ground that a heathen boy might attack a Jewish boy, since the term po includes also little babies of any age. But it is a matter of fact, that in the European countries where Jew-baiting prevails the Jews suffer more from schoolboys than from the grown up people. 
exaggeration of Haman's decree, its purpose being to induce the Jews of the Maccabean period to fight against their mortal enemies by arousing their fear and hatred. Less obvious would seem the reason for exaggerating Mordecai's decree. May we attribute the latter to the intention of presenting a counterpart to the decree of Haman on the part of the interpolators? Certainly not! The interpolators were persons of discretion, knowing well that the condition of the Jews was different from that of the Gentiles. Shall we ascribe it to a morbid state of mind which finds special delight in depicting carnage? The Jews never were of so sanguinary a state of mind as to enjoy descriptions of that sort, and the interpolators certainly were not! However, the exaggerations of both Haman's and Mordecai's decrees were due to the same motives. From the Books of the Maccabees we know that the Jewish people at that period were timid and indifferent, fighting only when it was absolutely necessary, but becoming careless as soon as the enemy retreated for a short time, and consequently many of them perished. ${ }^{20}$ The Greeks and Syrians committed atrocities, as if they had intended to carry out Haman's decree. ${ }^{21}$ If the Jews had acted in the same way, ${ }^{22}$ they would have burnt their own

20 See First Book of the Maccabees 8. 9, \&c.

${ }^{21}$ They had indeed murdered women and children, see ibid., 2. 39. For the benefit of the commentators who express high indignation at the decree of Mordecai, according to the Massoretic text, we may point to the historical records during the last sixteen hundred years, which show that in the innumerable attacks upon Jewish communities, the pious murderers, ad gloriam Dei magnam, never spared little children, but annihilated all alike. The same is true of the present as of the past.

22 According to the First Book of the Maccabees 5. 5 , the Jews in their reprisals killed only males However, it is doubtful whether this term includes male children. If they had done so for the sake of reprisal, they

H. 
ships, as it were, and would have been compelled to fight or perish. The aim of the interpolators in their exaggeration of these decrees was to arouse the Jews from their stupor, and urge them on to act as their ancestors did hundreds of years before.

The second performance of the Drama of Esther took place at the period of the Maccabees. From that time onward it became the favourite play of pagans, Christians, and Moslems alike. But the performance was never complete. There were actors more than enough for the parts of Haman and Ahasuerus, but none for those of Mordecai and Esther. The survival of the Jews in all these periods is therefore more remarkable and a greater miracle than the event recorded in the Book of Esther. Mordecai was thus perfectly right in predicting, that without Esther's intervention, 'relief and deliverance will arise to the Jews from another place'. The interpolators, seeing the Jews of their period playing the passive part of the performance, endeavoured to arouse them to a rôle of activity.

Now we have seen that the Greek version of our story is largely a paraphrastic translation. Its translator was unquestionably a learned and pious Jew, but we have reason to doubt his sagacity. The religious elements he inserted into our story, evidently by way of interpolation, shows his erroneous conception of the characters of Mordecai and Esther. Furthermore, the Greek translator ought to have accepted it as a matter of course that our author must have had sufficient reasons for omitting the name of God in his story, and ought not to have inserted it in his translation. On the other hand, our author, who could surely would not have spared adult females. But if they did spare the latter, would they not have spared little babies? 
recount such a wonderful story without supernatural elements - a feat unparalleled in the historical literature of antiquity - must have been an exceedingly clever man. If we nevertheless find that the Greek version in some points, is more natural and more reasonable than the Hebrew text, this difference is not due to the better sense of the Greek translator, but we may rest assured that in this case his version is a faithful translation of the original. Such is the case of Mordecai's decree. In the Greek

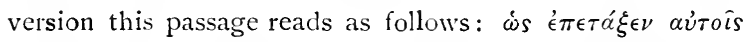

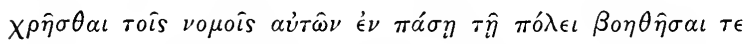

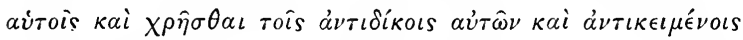
$\alpha \dot{v} \tau \hat{\omega} \nu \dot{\omega} s \beta o v \beta_{0 \nu \tau \alpha \iota}$. Comparing both the present Hebrew. and Greek versions, and, of course, making allowance for the licence of the translator, the original Hebrew text in

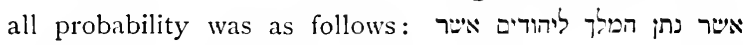
בכל עיר ועיר להקהל ולעםור על נפישם ולעישות בשינאיהם היצרים אותם כרצונם, i.e. "Wherein the king granted the Jews which were in every city, to gather themselves together, and to stand for their life, and to do unto their enemies, that would assault them, what they would '. ${ }^{23}$ This is exactly

${ }^{23}$ Haupt Critical Notes, p. I 77) is likewise of the opinion that Mordecai's decree as represented in the Massoretic text is not original, and sees in the terms טר ונשים ושללם לבוז their little ones and women, and to take the spoil of them for a prey', a gloss derived from the decrce of Haman (Esther 3. 13). He is right in seeing in it a gloss, but wrong in explaining it as a derivation. The interpolations in the decrees both of Haman and Mordecai come from one and the same source. But while מיש ועים may readily be admitted as a gloss, it is different with the second part לב. If this should be a gloss, there would be no need for our narrative to state ובבזה לא שלחו את ירם 'but on the spoil they laid not their hands', since a permission to that effect had not been given to the Jews. Yet this clause is repeated three times (9. 10, 15, 16). Shall we consider these repetitions likewise as glosses? But Haupt did not, and also on this point he is right. We shall further see, that the original Hebrew text, instead of 
what we would have expected to find in Mordecai's decree. More would have been evil. The clause ברצונם...... לעשות, 'to do... what they would', is a further confirmation that the Greek version on this point is a faithful rendering of the original Hebrew text. The present Massoretic text does not contain a corresponding phrase in Mordecai's decree. But in the execution of the latter, we actually find stated and they did what they would unto them that hated them'. This apparently indicates that the clause לעישות בישונאיהם כריצונם 'to do what they would unto their enemies', was found in the original Hebrew version of Mordecai's decree.

Of peculiar interest in the Greek version of Mordecai's

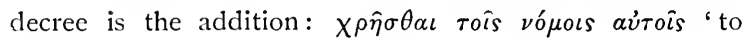
make use of their own laws', corresponding to a Hebrew phrase לעישות כדתיהם 'to do according to their own laws', or a similar phrase. If this clause is not a later interpolation, does it indicate that the translator was well aware of the cause of the danger impending over the Jews in that period? Such an assumption is not outside the bounds of consideration, as the original Greek version is very probably older than the present Massoretic text, and may well date from the third century B.C.E., as has already been pointed out. ${ }^{2+}$ Besides, the work of Hecataeus of Abdera, in which it was recorded that the Persians erected temples and altars in Palestine, and attempted to turn the Jews away from their religion, may well have been known

לעשות בשונאיהם כריצונם contained the phrase טף ונשים וישללם לבוז 'to do what they would unto those that hated them', and this actually entitled the Jews to the property of those who would attack them, and they nevertheless ignored this permission.

24 See chapter I, note 9 . 
to the Alexandrian Jews, and the translator might have perceived a connexion between this Jewish persecution by the Persians and the story recorded in the Book of Esther. However, this addition in the Greek version is illogical, and scarcely complimentary to the intellect of the translator. Our author would never have been guilty of such a defect of composition. For if Haman's decree had forbidden the observance of the Jewish laws, Mordecai's decree could not have permitted them, as a Persian law could not be reversed. But the first decree merely stated that the Jeres, that is to say, those who would still be Jews on the thirteenth of Adar, should be exterminated. Seeing that this decree was frustrated by that of Mordecai, which permitted the Jews to defend themselves against the attacks of their enemies, the Jews were in no need of being permitted the observance of their laws. Nor could that clause refer to the exemption from the worship of Anahita, that this worship should not be incumbent on the Jews, because it was inconsistent with their laws, as the worship of Anahita having become a Persian law, it could not be revoked, though for the time being it was not enforced.

As long as the fate of the Jews was still in the balance, Esther 8 . Mordecai was not yet in a frame of mind to appear 15-16. publicly with the pomp and splendour of a grand vizier. Though the people knew that he was in great favour with the king, there was no outward manifestation of his high position. Seeing, however, that he called the king's scribes and sent out decrees, this left no doubt that he was installed in Haman's place. The author, therefore, after the description of the decree, states: 'And Mordecai went forth from the presence of the king in royal apparel of blue and white, 
and with a great crown of gold, and with a robe of fine linen and purple'. Witnessing the high position of Mordecai, and considering that looking gloomy would be of no use, a great many of the inhabitants of Susa considered it good policy to be on friendly terms with the powerful minister, and pretended to rejoice at his good fortune. This may be the meaning of the statement, 'the city of Shushan shouted and was glad'. Seeing that the Jews had been for many years persecuted and branded as a turbulent, disloyal element, we may rest assured that a large number of the population was not favourably disposed toward them and looked upon them with a certain degree of contempt or hatred. Whether they approved of Haman's decree or not, their sentiments toward a member of a people recently condemned to destruction, who had been elevated to the highest office of the empire, could scarcely have been sincere. Outwardly, however, the people rejoiced and applauded the new minister. ${ }^{25}$ But there may have been not a few whose sentiments toward the Jews were different, and their joy at Mordecai's elevation was indeed sincere, as we shall see later.

Esther 8. The sudden change in the conditions of the Jews could 17. not but make a deep impression on the mind of many Gentiles. For a considerable period the latter witnessed the persecutions the Jews underwent on account of their

25 The mocking remarks of Siegfried and others about the statement of our narrative that people of Susa 'shrieked with delight' at the elevation of Mordecai are naive. Moreover, the commentators who deem it so preposterous that heathens should have rejoiced at the high position of Mordecai, which actually meant the deliverance of the Jews from annihilation, ought to ridicule also the Psalmist who exhorts 'all the nations to give praise unto the Lord for His merciful kindness toward Israel' (Psalms II 7. I, 2). At that period, there might have still existed unsophisticated people willing to acknowledge the working of Providence. 
adherence to their creed, seeing them obstinately refusing to bow down to idols and heroically suffering for their own convictions. Many a Gentile, though not ill-disposed toward them, may have ridiculed their superstition in trusting implicitly in the God of Israel. Others may have pitied them for their foolhardiness. A good many of them may have been horrified at their impiety, and regarded the fate impending over them as well-deserved, and felt assured that the gods whose worship they flaunted and whose existence they denied would not suffer them to escape with impunity. Seeing the unexpected deliverance of this people, when their final doom seemed to be inevitable, many Gentiles may well have become convinced of the truth of the Jewish belief, and may have exclaimed like Jethro: 'Now I know that the Lord is greater than all the gods.' Scepticism was scarcely known at that period, among the Persians at least, and the people evidently ascribed the escape of the Jews to the power of their deity. Therefore, many of them may well have thought that the only way of escaping divine punishment for having scoffed at the belief in such a mighty God was to recognize his godhead and to worship him. If our author had not been extremely careful in avoiding the name of God in this

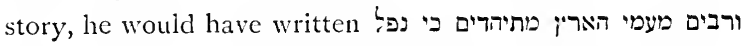
פחר ה' עליהם 'And many of the peoples of the land became Jews ; for the fear of the Lord was fallen upon them.' But considering that פח is an ambiguous expression, as it occurs once in the Bible as synonym of איה 'God' as 'the object of fear' (Gen. $3^{\mathbf{I}}$. 53), the author may have intentionally used this expression which is capable of being understood in both meanings. Now we have seen that even in the most abject state of the Jews in Babylonian 
captivity, many Gentiles became converts to the Jewish religion, a fact which even the most sceptical critics who regard the statement of our author on the point under discussion as incredible, do not and cannot deny.

However, it would be unfair to censure the modern commentators for doubting or flatly denying the author's statement that 'many of the peoples of the land became Jews'. Their view is due to the fundamental error of the current interpretation, that the danger to the Jews recorded in our story was the effect of a mad freak of Haman who for the purpose of wreaking vengeance on a single individual intended to destroy his whole race. If their danger was not solely due to their creed, there was no reason for the Gentiles to ascribe the escape of the Jews to the power of their God. No god worthy of that name, be it Marduk, Shamash, Nergal, Ahuramazda, or any other deity in a pagan pantheon, could have permitted the completion of so execrable a design. Thus, there was not the least occasion for any Gentile to part with his own ancestral belief on account of the event. On the contrary, the Gentiles might have become even more firmly convinced of the belief in their own gods who prevented their people from committing so horrible a deed. Hence, it would, indeed, require childlike simplicity to accept the author's statement that many Gentiles due to the miraculous escape of the Jews accepted their religion. Furthermore, Haman's decree having been in force only for a short time, and thus the whole excitement caused by the latter having been a tempest in a teapot, as pointed out in the first chapter, the frustration of the decree could scarcely have made any impression on the mind of the Gentiles.

Different, however, is the conception of our story, if we 
consider that the Book of Esther records the last phase of a series of religious persecutions, extending over a period of many years. It was a struggle not between human forces but between Polytheism and Monotheism. The people that witnessed this struggle were scarcely indifferent to its outcome. The natural desire of man being to place himself under the protection of the most powerful deity, the most sincere votaries of the gods may have been shaken in their belief and fully acknowledged the power of the God of Israel. Now we may, of course, question whether the Gentiles who did so were willing and ready to change their whole mode of life and accept the religion of Israel with all its observances. We may even doubt whether those who, carried away by this impression, accepted Judaism did not revert to the old beliefs of their ancestors after a certain time. But on this point we know nothing. Some of the converts may have reverted to their former beliefs and some may not. However, we must bear in mind that the structure of Judaism with all its observances had not been fully established among the Jews of that period, and thus the observance of all biblical laws was not yet characteristic of the Jewish creed. Only Monotheism, the Covenant of Abraham, and the observance of Sabbath, were the points of division that separated the belief of the average Jew from that of the Gentile. Now to the average Jew, Jahveh and Ahuramazda were identical in all respects but in name. Thus Monotheism was not specifically characteristic of the Jewish religion, as Zoroastrianism was apparently based on the same doctrine. Nor was circumcision exclusively characteristic of the Jewish religion, as it was generally practiced by the Phoenicians, Arabians, and probably also by other Semites. Concerning the 
observance of the Sabbath, we have no records to ascertain the conduct of the average Jew of that period regarding this precept. But we know that in the period of Nehemiah, about forty years before the event of Purim, the Sabbath was not generally observed by the Jews of Palestine, as Nehemiah himself testified: "In those days saw I in Judah some treading winepresses on the Sabbath, and bringing in heaps of corn, and lading asses therewith; as also wine, grapes, and figs, and all manner of burdens, which they brought into Jerusalem on the sabbath day. ... Then I contended with the nobles of Judah, and said unto them: What evil thing is this that ye do, and profane the sabbath day? Did not your fathers thus, and did not our God bring all this evil upon us, and upon this city? Yet ye bring more wrath upon Israel by profaning the sabbath' (Neh. I3. I $5^{-2} 3$ ). If this was true of the Jews of Judah, we have no reason for the assumption that the average Jews of the diaspora, especially those in the interior provinces of the Persian empire, were less lax in the observance of the Sabbath, and it is likely that the same conditions still prevailed in the period of Mordecai. Thus the Gentiles who embraced Judaism were not greatly burdened with religious observances, and did not have to change their whole mode of life on account of this step, as their religious conduct as Jews may have been neither better nor worse than that of the average Jew. Furthermore, some of the Zoroastrians, seeing the deterioration of the Persian religion, may have resolved upon accepting a belief in which the Zoroastrian. doctrine was preserved in purity. Considering all these points, the author's statement under discussion is not only very probable, but also historically almost beyond any reasonable doubt. 
Cassel, however, cannot bring himself to believe that many Gentiles had broken the ties to their nationality to enter Judaism. ${ }^{26}$ This objection is, of course, based upon the almost generally accepted conception that a Gentile had to sever his connexions with his own nationality, if he embraced Judaism-this conception is the fundamental basis of anti-Semitism. The biblical scholars holding this view are forced to maintain that the post-exilic religion of the Jews had still preserved its character as a national religion, and Prophetic Universalism did not enter into the scheme of Judaism, and did not modify its original character. But this opinion is fundamentally and historically untenable, and there is no need to enter into a discussion of this subject, as it was thoroughly treated in the fifth chapter.

However, though Cassel's doubt concerning the author's statement is fundamentally wrong, his emendation ורבים מעמי הארין מתיחדים כי נפל פחד היהודים עליהם, i.e. 'And many of the peoples of the land united themselves (with the Jews); for the fear of the Jews was fallen upon them', is ingenuous, but linguistically scarcely correct, as then we would have to read מתיחדים עמהם, they united themselves with them'. Otherwise, the passage would be ambiguous, and could just as well be translated, 'and many of the peoples of the land united themselves against them', and if that had been the case, the Feast of Purim would scarcely have been instituted. Josephus, indeed, records such a union of Gentiles against the Jews that was disastrous to the latter. At Seleucia the Syrians were always at odds with the Greeks, and the Jews held the balance; but one day, the Greeks united themselves with the Syrians, 
and together they slew about fifty thousand Jews. ${ }^{27}$ Whether this tale be true or not, a worse fate would have overtaken the Jews in the days of Ahasuerus, if the Gentiles had united themselves against them.

Jampel, however, while admitting the improbability that at this period Gentiles should have embraced the Jewish religion, declares that the current translation of the passage under discussion is erroneous, and that it ought to be translated: 'And many of the peoples of the land pretended to be Jews'. ${ }^{2 s}$ But though linguistically such a translation would be permissible, as the Hithpa' $\mathrm{cl}$ form may mean 'to pretend to be something or someone', such a statement would be historically more incredible than that of the current translation. We must consider that no pagan can pretend to be a Jew without denouncing idolatry, and no sincere idolator was likely to denounce his ancestral gods to curry favour with the Jews. The religious feeling of the pagans was no less strong than that of the Jews and Christians. We know that the sincere pagans abhorred the religions of the Jews and Christians, regarding them as nothing short of atheism. Thus the

${ }_{27}$ Josephus, Antiquities, XVIII, 9, 9.

28 Jampel, Das Buch Esther. He thinks that pagans pretended to be Jews for the purpose of escaping the massacres, just as Jews in the Russian pogroms placed a cross in their windows as a sign that those dwellings were inhabited by Christians. But he is wrong from every point of view. The Jews of that period were granted permission only to defend themselves, and the pagans who kept quict were absolutely safe from any attack. Furthermore, according to the testimony of the prophet Jeremiah : 'Hath a nation ever changed the gods? and yet they are no gods, but my people have changed their glory for that which does not profit' (Jer. 2. II), the pagans were incomparably more faithful to their own gods than Israel to Jahveh. Thus. it would never do to say that out of fear the pagans pretended to be Jews, an action that implies faithlessness toward their ancestral gods. 
author's statement would not gain in probability through that translation.

The fact that in this period Gentiles became converts to the Jewish religion is apparently again referred to in phapter 9. 27 : קימו וקבלו היהודים עליהם ועל זרעם ועל כל הנלוים עליהם, i. e. 'The Jews ordained, and took upon them, and upon their seed, and upon all such as joined themselves unto them'. Now it is interesting to note that the expression כall such as joined themselves unto them', strongly resembles the almost identical expression of the exilic Isaiah בני הנכר הנלוים על ה' the sons of the stranger that joined themselves unto the Lord'.29 Our author may actually have had the latter passage in mind when he used a similar expression, and might have used the identical phrase, if he had not been over-anxious to avoid the name of God in his story. But there must have been some reason why our author should have especially referred to converts in this passage. Now the question arises: To what converts does this passage refer? There was no need for including converts who had accepted Judaism long ago among those upon whom the observance of Purim was obligatory, as they were Jews in every respect, and likewise in danger of being exterminated. Was it necessary to include converts of later times? Certainly not, since Gentiles on entering Judaism accept indiscriminately all Jewish customs and observances. Thus it seems that our author in this passage actually referred to those who had recently accepted Judaism after the downfall of Haman and the escape of the Jews. The latter not having been in danger of being exterminated had no proper obligation for the observance of Purim.

29 Isaiah 56. 6. 
But since the latter was made by common consent a Jewish festival, it became obligatory on all adherents of the Jewish religion. In including the latter, our author may have meant to imply that the newly-converted Gentiles derived from the event the benefit, that they became votaries of the God of Israel, thus gaining a spiritual redemption, and that therefore they had a real cause for celebrating Purim as a Memorial Day.

Though Mordecai's decree did not avert the danger to the Jews altogether, since Haman's decree could not be reversed, and they were only given permission to defend themselves, the author nevertheless states: 'And in every province, and in every city, whithersoever the king's commandment and his decree came, the Jews had gladness and joy, a feast and a good day'. But this statement does not indicate that the Jews had no longer any cause for apprehension. They rejoiced at having been given a chance of fighting for their existence, and not because the danger was completely past. At the time of the Maccabees, the Jews did exactly the same, feasting and celebrating after the defeat of the Syrian army, though well knowing that the enemy was repulsed only for the time being, and that they would have to fight many battles for their cxistence. The condition of the Jews at that period was less hopeful than that of the Jews at the period of Esther. ${ }^{30}$

Esther 9. That the danger to the Jews was not completely I-5. averted is indicated in the opening lines of the ninth chapter of our story, which reads as follows: "Now in the twelfth month, which is the month Adar, on the thirteenth day of the same, when the king's command and his decree drew near to be put in execution, in the day that the 30 Sce First Book of the Maccabees 4. 36-6o. 
enemies of the Jews hoped to have rule over them; whereas it was turned to the contrary, that the Jews had rule over them that hated them'. Now considering that Haman's decree was absolute, enjoining on all the people to destroy the Jews, while Mordecai's decree was merely conditional, permitting the Jews to defend themselves against those who should attack them, it is not likely that the clause, 'when the king's command and his decree drew near to be put in execution', refers to the decree of Mordecai, as the latter would never have been put in execution if the Jews had been left unmolested. Thus, this clause evidently refers to the first decree which was still in force, as it could not be reversed, and therefore, notwithstanding Mordecai's decree, 'the enemies of the Jews still hoped to have rule over them '. ${ }^{31}$ But on the day of decision their hopes were not realized, and 'it was turned to the contrary, that the Jews had rule over them that hated them'.

Now in villages and small places, the Jews living there were absolutely defenceless. These scattered individuals, if they had tarried there on the fateful day, would have been exposed to certain destruction. Therefore, "The Jews gathered themselves together in their cities throughout all the provinces of the king Ahasuerus'. Their aim was not to avenge themselves on those who formerly had

31 Seeing that Haman's decree was in force only for a short time, it does not seem probable that the clause, 'the enemies of the Jews hoped to have rule over them', should refer to the brief period that elapsed between the decrees of Haman and Mordecai. It is more probable that this clause meant to indicate: notwithstanding Mordecai's decree, the enemies of the Jews still hoped to have rule over them. This hope was well founded, as without interference they surely would have prevailed over the Jews. 
hostile intentions toward them, as such an unprovoked attack would not have been in accordance with the decree, and the royal officials would have prevented it if they had overstepped their authority. Their only purpose was 'to lay hands on those who were still secking their hurt' (מבקיטי רעתם), but not on those who had abandoned their intentions of attacking them. ${ }^{32}$ The mob eager for plunder, and considering that the Jews were disliked on account of their hostile attitude toward the polytheistic religions, reckoned upon the assistance of the average citizens, expecting them, in case of being overthrown, to make common cause with them. But they were disappointed in their expectations. The people at large did not come to their assistance, and remained neutral. ${ }^{33}$ The Jews succeeded in overwhelming their adversaries, 'and no man could withstand them; for the fear of them was fallen upon all the peoples'. But it is evident that it would not have been physical fear that prompted the average citizens to

32 Not without intention our author used the term מבקשי רעתם 'seeking their hurt', and not a verbal clause בקישו רעתם 'who sought their hurt', to indicate that the Jew had attacked only those who even now were intent upon doing them bodily harm. How could it have been otherwise, since in Mordecai's decree they were given permission only 'to stand for their life', and in the execution of this decree, we are distinctly informed: 'They gathered themselves together and stood for their lives?' Thus there is not the least justification for the interpretation of Wildeboer and other commentators, that the Jews killed all who were reputed to be their enemies. Haupt (Critical Notes, pp. 176, 180) is one of the few commentators who protest against such a distortion of the truth.

בי נפל פחדם על כל העמים Haupt Critical Notes, p. 180) regards 'for the fear of them was fallen upon all the peoples', as an illogical scribal expansion. But he is wrong. Our narrative meant to indicate: None of the enemies who attacked them could prevail over them; and this was not because the Jews were more powerful or more numerous, but due to the fact that the people at large did not participate in the attacks upon them out of fear. 
their neutral attitude. It is more likely that they attributed the deliverance of the Jews to the powcr of their God and thus thought it morc advisable to leave them unmolested. If so, we may suggest that also in this description, but for the intention of avoiding the name of God in this narrative, ואי": לא עמד בפניהם ואיה בי נפל פחר ה' על כל העמים and no man could withstand them; for the fear of the Lord has fallen upon all the peoples'.

However, the mob which are ready to fall upon the Jews, though greed was the ulterior object of their attacks, acted within their rights and their duty, in executing a royal decree which was still in force, and were incomparably more numerous than the Jews, notwithstanding the neutral attitude of the average citizens. The Jews alone, with their own resources, might never have succeeded in defeating their adversaries and repelling their attacks. Their victory was largely due to the fact that 'all the princes of the provinces, and the satraps, and the governors, and they that did the king's business, helped the Jews'. Our author may have used intentionally the somewhat ambiguous term מה: properly 'exalting, lifting up', but also though rarely 'supporting', instead of the current term עומרים 'helping'. Bearing in mind that the mob in their attacks did not act lawlessly, the royal officials could neither prevent them, nor array their military forces on the side of the Jews against their adversaries, but could indirectly place many obstacles in the way of the attacking mobs, while assisting the Jews in procuring arms for their own defence, and in many other ways. However, this assistance on the part of the officials was scarcely due to a change of heart, seeing that the same officials had been for years II. 
the very instruments of Haman in his persecution of the Jews, and thus it is unlikely that they suddenly became favourably inclined toward them. The Jews certainly detested many of these officials as the murderers of their brethren, and this feeling was probably reciprocal. Now legally no blame could have been attached to the officials if they had remained neutral in the encounter between the Jews and their adversaries, or even if they had actually assisted in the execution of Haman's decree. But, as officials they depended upon the goodwill of the grand vizier, and it was scarcely likely that Mordecai would have retained them in their office if they had assisted in the destruction of his people. Thus their favourable attitude toward the Jews was due to their fear of the grand vizier : 'because the fear of Mordecai was fallen upon them'.

Esther 9 . $6-i 5$.

Of special importance in the description of the defence of the Jews against their adversaries are the events at the capital Susa. As far as the execution of Haman's sons is concerned, their death, if not pardoned by the king, was inevitable, as in Persia the condemnation of a grandee involved his whole family, and they might have been executed at any time, but it was appropriate that their execution should occur on the day that Haman decreed for the extermination of the Jews. Nor is it strange that the Jews should have been entrusted with the execution of the sons of their formidable adversary. Of the other enemies who attacked them, the Jews killed five hundred men, and we may rest assured that those who attacked them were more numerous and may have numbered many thousands. Esther, however, was not satisfied with this victory of the Jews, and requested the king: If it please the king, let it be granted to the Jews that are in Shushan 
to do to-morrow also according unto this day's decree, and let Haman's ten sons be hanged upon the gallows. And the king commanded it so to be done; and a decree was given out at Shushan; and they hanged Haman's ten sons. And the Jews that were in Shushan gathered themselves together on the fourteenth day also of the month Adar, and slew three hundred men in Shushan'. Now Esther's reputation as a bloodthirsty woman, and the aversion to the Book of Esther among many biblical scholars and critics is largely, if not exclusively, due to this request of Esther. The same is true of the critics who do not believe in the historical character of this narrative, as they see in the description of such a request the revengeful character of our author. As to the latter critics, none of them can find a reasonable explanation for such a request. ${ }^{34}$ Yet the reason underlying this matter is obvious. Seeing that the Jews were merely granted the right of defending themselves against the people that would assault them, ${ }^{35}$ how could they have done so on the fourteenth of Adar if they had not been attacked? Did Esther request a special permission for the Jews to attack their enemies, even if the latter should leave them unmolested? She

34 The consensus of opinion of the commentators on this point is expressed by Paton, p. 287: 'For this horrible request no justification can be found. A second massacre was in no sense an act of self-defence, since the power of the enemies of the Jews had already been broken by the events of the thirteenth of Adar. This shows a malignant spirit of revenge more akin to the teaching of the Talmud than to the teaching of the Old Testament.'

35 Keil, p. 609, in arguing against Blcek, maintains that Esther was afraid lest the Jews might be attacked on the following day as well, and that they were indeed attacked. His interpretation and justification of Esther's request is ignored by the modern commentators. Paton (see preceding note) ought at least to have statcd that there are conscrvative exegetes who attempt to justify Esther's request. 
certainly did not, as her distinct request was: 'to do to-morrow also according unto this day's decree' (כיעות) כדת היום). This conclusively proves that the Jews must have anticipated an attack of their adversaries on the following day. But the force of Haman's decree expiring with the thirteenth of Adar, what grounds of apprehension did the Jews have for such a supposition, as an attack on the next day would have been illegal and could easily be prevented by the royal forces? This leaves no room for doubt that Haman's decree for Susa was different from that for the provinces, a fact already pointed out in the preceding chapter, and deduced from Mordecai's account of that decree to Hathach, the messenger of Esther. Susa having been the centre of the empire, the assumption is within reason that the Jewish population there was numerous, just as it was in later periods in Alexandria, Antiochia, Rome, \&c. The task of destroying a numerous population was not easy. The Jews, no doubt, would have offered desperate resistance to their adversaries. One day was insufficient for accomplishing their destruction. For this reason the people of Susa were given two days to rid the city of the Jews. But after Haman's downfall, Mordecai saw no reason for giving the Jews of Susa two days for their defence, believing that the people of the capital, in the proximity of the king, would not dare to attack the Jews. This was an error of judgement. In no other localities was the temptation to plunder the Jews so alluring as in the capital, where the wcalthiest Jews resided. The Jews there were, of course, numerous. But just as Alexandria, Antiochia, Rome, and other capitals were points of gravitation not only for the Jews but also for all sorts of disreputable characters to whom murder meant nothing, if there was 
any profit to be derived from it, so was Susa. Thus the lower strata of society were more numerous there than the Jews, and did not hesitate to exccute Haman's decree, being certain of accomplishing their task. Though repulsed on the first day, they were not discouraged, and intended to resume their attack on the following day. They could legally do so, in accordance with Haman's decree, but the Jews had no legal right of defending themselves and offering resistance to a royal decree. Self-defence would have been natural and pardonable, but not lawful, and the conscience of acting in a lawless manner is discouraging, and would have given an advantage to their enemies over them. Seeing that in the issuing of the decree an error had been committed, Esther hastened to the king to correct it. Upon being informed by the king that in the encounter of the Jews with their adversaries the former had been victorious and killed five hundred men, Esther answered: This is of no avail. The condition of the Jews is still precarious. The enemies would resume the attack tomorrow, and the Jews have no legal right to defend themselves. Therefore the force of the decree ought to be extended for the next day. Furthermore, the exposing of the bodies of Haman's sons might have a deterrent effect upon many of the people, and thus might save bloodshed and make it easier for the Jews to defend themselves. The king granted Esther's request, which was not unfounded, as on the next day the Jews were attacked again and defended themselves successfully: ${ }^{36}$

36 The commentators who condemn Esther's request are wrong cven from their own point of view. If the Jews had been permitted to attack all those who had wronged tirem in the past, does it stand to reason that those who had escaped on the thirteenth of $\Lambda$ dar should get away with impunity? 
Esther 9. The number seventy-five thousand of the slain Gentiles 17. in all the provinces of the empire is in all probability a late exaggeration. The Greek version reports fifteen thousand. However, if the Jews had been actually attacked everywhere in all localities, the former number would have been too low an estimate. But there is scarcely room for doubt that in most places the Jews were left in peace and, thus, under no necessity of defending themselves. For a mob intent upon plunder is, as a rule, cowardly, and perceiving the Jews well prepared for their defence, and moreover, being assisted by the officials, did not make any attempt to execute Haman's decree. This fact may perhaps be seen in the clause, 'and had rest from their enemies' (ונוח מאויביהם). This statement seems to be out of place in this connexion, and the author may have intended to indicate thereby, that in some localities they had rest from their enemies and were not compelled to defend themselves.

However, though the Jews were victorious and thus succeeded in frustrating Haman's decree, we must not imagine that they did not suffer any losses in the encounters. It goes without saying that many Jews must have lost their lives in these riots, and the number of their slain brethren altogether may have been not much below that of their enemics. Our author, however, is not to blame for omitting this fact, as on this point he acted like all other biblical authors, who only in case of defeat, but not in that of victory, record the losses of the Jews in their wars. We are not informed whether any Israclites fell in the battles against Sihon and $\mathrm{Og}$, at the conquest of Canaan, in the wars of Deborah, Jephtha, \&c. The Books of the Maccabees do not inform us either of the losses of 
the Jews in their victorious campaigns. The same is true of the Book of Fsther. Facts of this kind we have to read between the lines. But the loss of the men who fell as champions of Israel did not prevent the survivors from celebrating joyfully their deliverance from complete annihilation.

Now in the description of the successful defence of the Jews, it is repeatedly stated, 'But on the spoil they laid not their hands', and our author intended to emphasize thereby that the Jews in their encounters with their adversaries were not actuated by greed, and ignored the provision of the second decree that permitted them 'to take the spoil of them for a prey'. But this provision is found only in the Massoretic version of Mordecai's decree, while the Greek version of the latter has no reference to the spoil of the Jews' enemies. Nevertheless, in the execution of the decree, 9. 15,16 , the latter version contains the

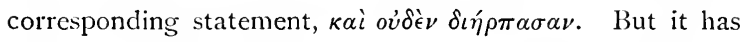
been repeatedly pointed out that the Greek version is a rendering of the original Hebrew text of our story, while the present Massoretic text had been considerably interpolated in a later period, and this contention does not seem to be borne out in this case at least, where the Greek version testifies to the originality of the Massoretic text. However, the permission 'to take the spoil of them for a prey' may be implied in the clause 'to deal with their adversaries according unto their own will' ( $\chi \rho \hat{\eta} \sigma \theta \alpha \iota$ rois

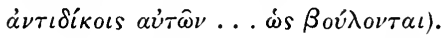

The Festival of Purim commemorating the deliverance Esther a. of the Jews from utter destruction, having been established, according to the testimony of our narrative, by Mordecai and Esther, and not by the Sopherim, had no religious 
character. The Sopherim, though grateful to Mordecai and Esther for their intervention, could not have proclaimed them as saviours of Israel. The Rabbis seemed to have preserved a tradition that the Sopherim refused to sanction the establishment of Purim." Mordecai and Esther, the founders of this festival, having no religious authority, could not encumber the Jews with new religious observances. Moreover, considering their character, we may doubt whether they greatly cared for religious ceremonies, and it is not likely that they would have been inclined to impose them upon other people. Thus Purim was a purely secular festival, like Independence Day, on the Fourth of July, the character of which would unquestionably have been different, and might have been like the American Thanksgiving Day, if it had been instituted by the Church. But many years later, having been successfully introduced and generally established, the Festival of Purim had to be taken cognizance of by the Sopherim. Otherwise, having a secular character and being celebrated simultaneously with a great Persian festival, as demonstrated in chapter VII, Purim was bound to become an idolatrous festival and to be identified with that of the Persians, as, indeed, modern scholars do. To prevent such an identification, the Sopherim wrote down the story of Purim and introduced its reading in the synagogues.

The special features of this Festival were, 'sending portions one to another, and gifts to the poor'. Now modern critics call attention to the fact that the old Persian festival Farwardigan had been celebrated in the same way. ${ }^{38}$ But it is quite natural that a Jewish festival instituted in the Persian empire should be celebrated in 
accordance with the customs of the country, provided the latter are not of a polytheistic character or contrary to the Jewish ethical conceptions. The originators of the Festival of Purim were Mordecai and Esther, and having been Pcrsians, ordered its celebration according to Persian customs. If its originators had been the Sopherim of Babylonia or Palestine, we may doubt whether these Persian customs would have been made its special features. However, these customs, conducive to the promotion of goodwill and charity, are so fully in accordance with Jewish ethics that, no matter what their origin may have been, the Sopherim could not have abolished them when they sanctioned Purim as Jewish festival.

Our narrative distinctly states that Mordecai himself Esther 9 wrote down the antecedents of the memorial days which the Jews should establish among themselves: 'And the Jews took upon them to do as they had begun, and as Mordecai had written unto them.' 39 Our author thus testified to the existence of a 'Letter of Purim', written by Mordecai himself, an historical source, from which he drew in the composition of his narrative. But, while we have no means to ascertain how far he relied upon this historical document, and how far upon the testimony of eye-witnesses or tradition, there can be no room for doubt that in the verses $2+-5$ we have an almost literal quotation from the Letter of Mordecai. This quotation contains a pithy account of the causes of both the danger to the Jews and their deliverance. This account being an historical source of the first importance,

39 The clause את • אישר החלו לעשות (the Jew's took upon them) to do as they had begun', can scarcely refer to the first year in which they had been delivered from their enemies, as Haupt explains, but it is more likely that the Jews spontaneously began to observe the days of their deliverance as Memorial Day's. 
it is worth while to investigate whether it is fully in agreement with that presented by our author in his narrative.

The Massoretic text containing Mordecai's own account of the antecedents of Purim ${ }^{40}$ reads as follows :

'Because Haman the son of בי המן בן המרתא האגני

Hammedatha, the Agagite, the enemy of all the Jews had devised against the Jews צורר כל היהודים to destroy them, and had cast pur, that is, the והפיל פור הוא הגורל lot,

to discomfit them, and to cleלהמם ולאברם stroy them; but when she came before the ובבאה לפני המלך king, he commanded by letters אמר עם הספר that his wicked device which י"שוב מחישבתו הרעה אישר הישב he had devised against the Jews, should return על היהודים על ריאישו upon his own head; and that he and his sons should ותלו אותו ואת בביו

be hanged on the gallows.' על העיi

A critical examination of these passages purporting to contain a quotation from Mordecai's Letter of Purim shows clearly that the present Hebrew text could not have been

40 The contents of Mordecai's Letter of Purim ought to have been given after ibetween verses 22 and 23 , and it looks like an afterthought of our author in quoting this letter after informing us that 'the Jews undertook to do as they had begun, and as Mordecai had written unto them'. This guotation was indecd unnecessary, and its only purpose was to explain the name of Purim: "Wherefore they called these days Purim, after the name of Pur.' 
handed down correctly, as we encounter there numerous difficulties. In the first place, our author being a rery good stylist, it is rather strange that just here his style should be so awkward as to contain identical expressions, as לאבדם repeated twice in one and the same verse, ${ }^{41}$ and repeated in two verses following immediately one another. Secondly, the singular term למר, which literally means 'to excite, disperse, drive away', is here out of place. Cassel's suggestion that the author used this term as a play upon the name of Haman, ${ }^{42}$ is not to be taken seriously. ${ }^{43}$ Thirdly; the clause ובבאה לפני המלך, if it should be translated 'and when she came before the king', referring to Esther, as generally interpreted, would be syntactically wrong, as Esther had not been mentioned in the context. The suggestion of many modern commentators that the suffix in ובבאה should be construed as neuter, referring to the conspiracy of Haman, and thus the clause should be translated 'and when it came before the king ', 4 rests upon the fundamental error in the interpreta-

41 Siegfried believes that the first

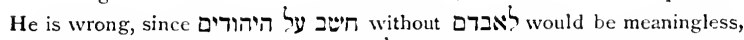

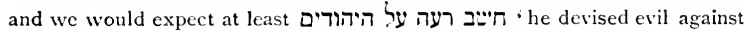

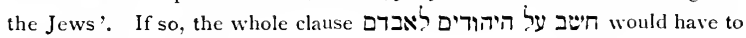
be regarded as a gloss.

${ }^{42}$ Similarly Haupt (Critical Notes, p. I88), who observes: 'The assonance with the name Haman might be imitated by translating: to harm them or to mayhem them'.

43 However, the possibility that some Sopher at the Purim-table permitted himself the witty remark הכי נקרא "שמו המן כי המן - Was he not rightly named Haman, for he had excited us?', may be frcely granted. But this would not have been inserted in the text.

44 So Bertheau-Russel, Wildeboer, Siegfried, \&.c. But these commentators correctly contend that Haman did not obtain his decree by a conspiracy, and that the king was well aware of the fact that it was aimed at the Jews. In accepting this interpretation, we would have to assume 
tion of the event, assuming that the king did not have the slightest knowledge of Haman's intentions in confirming his decree, and that it was a conspiracy on the part of Haman. Thus such a construction of the suffix in ובבאה is impossible. Fourthly, the peculiar expression הפכ, which literally means 'he said with the letter', if it should mean 'he commanded by letters', as translated above, would be rather awkward, and can scarcely be attributed to our author. He could not have been at a loss for a proper expression, as the phrase נתן רת frequently occurs in this narrative, and could have expressed himself : : Fifthly, according to our narrative, the ling did not command by letters that Haman and his sons should be hanged, and it is unlikely that our author should have quoted a version contradicting his own narrative. ${ }^{45}$ Finally, the king did not say exactly that Haman's wicked device should return upon his own head.

But, while in the Massoretic text we encounter linguistic and exegetical difficulties, turning to the Greek version, the corresponding passages are clear and in full agreement with the preceding narrative. This version reads as follows :

'How Haman the son of $\pi \hat{\omega} s{ }^{\prime} A \mu \grave{\alpha} \nu ' A \mu \alpha \delta \delta^{\prime} \theta o v$ ó $M \alpha \kappa \epsilon-$ Hamadatha, the Nacedo- $\delta \dot{\omega} \nu$ nian,

that Mordecai's version of the main event differed on the most essential point from that of our author. Haupt Critica! Notes, p. 188) likewise objects to such an interpretation, and observes: ובבהה when it came, but when she cime. The author of the original book would not have written ובבאה, but ובבוא אםתר לפני הפלך'. However, there must be some reason why the latter expression should have been ehanged in the Massoretic text to ובבאה.

${ }^{45}$ Or should it refer to the decree given in Susa at Esther's request that Hanan's sons after their death should be impaled? 


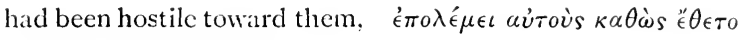
and how he had cast

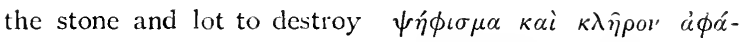
them;

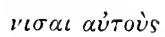

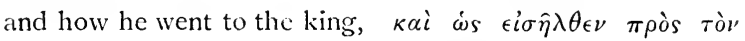

$\beta \alpha \sigma \iota \lambda \epsilon{ }^{\prime} \alpha$

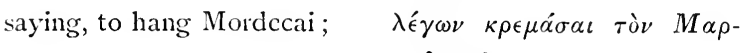

$$
\delta o \chi \alpha \hat{\imath} 0 v^{\prime}
$$

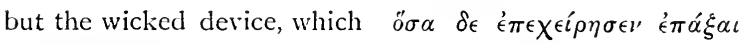
he devised

$$
\text { '́ti roùs }
$$

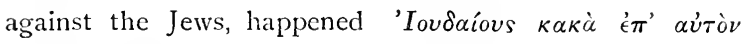

$$
\text { unto himself, }
$$

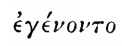

and he was hanged himself and his own children.'

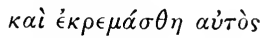

$\kappa \alpha \grave{i} \tau \grave{\alpha} \tau \hat{\epsilon} \kappa \nu \alpha \alpha \dot{\tau} \tau o \hat{v}$.

With the exception of rendering $\operatorname{Ag}_{\mathcal{S}} \overline{\mathrm{q}} \bar{\imath}$ with 'Macedonian' which in Alexandria may have been an idiomatic designation for an inexorable enemy of the Jews, and making allowance for the clause 'saying, to hang Mordecai', corresponding to the Hebrew לאמר למלך לתלות את מרדבי (Esther 6.4), which is no doubt a mere expansion, there is not the least objection, be it linguistically or excgetically, to the contents of Mordecai's presentation of the antecedents of Purim in the Greek version. Thus the original Hebrew text that was rendered into Greek must have read as follows :

- Because Haman the son of בי המן בן המרתא האגגי Hammedatha, the Agagite, the enemy of all the Jews, had צורר כל היהודים הפיל פור cast pur, that is, the lot, to destroy them ; הוא הגורל לאברם למני But when he came before the ובבאי לפני המלד king, 
returned his wicked device שב מחישבתו הרעה אשר חישב which he had devised against the Jews upon his own על היהודים על ראישו head, and they hanged him and his ותלו אותו ואת בניו על העין sons on the gallows.'

Thus, according to this statement quoted from Mordecai's Letter of Purim, Haman's downfall was caused when he came to the king with the intention of asking permission for Mordecai's execution. This is essentially true, as Haman's humiliation foreshadowed his downfall. To be sure, Haman himself did not have a chance of laying this request before the king. However, it has been pointed out, that but for Harbonah informing the king of the gallows prepared by Haman for Mordecai's execution, Haman might have been brought before the judges, according to Persian laws, and in this case might have been able to prove his innocence, and then perhaps regained his influence with the king, and thus his final downfall was actually due to his intention of executing Mordecai. This was the interpretation of the Greck translator of the clause ובבאה לפני המלך, expressing it by the addition $\lambda \boldsymbol{A}^{\prime} \gamma \omega \nu$

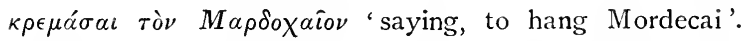
However, this interpretation is by no means certain, as the clause under discussion may mean that Haman's downfall was caused when he came to dine with the king on Esther's invitation. This would be fully in agreement with the account of our author.

However, the corruption of these passages in the Massoretic text cannot be without reason, and requires some explanation. May this not be due to marginal notes ובבאה of some exegetes who tried to interpret the clause 
לפני המלך in various ways? That exegetes must have tampered with the text under consideration is plainly seen from the difference between the Massoretic and Greek versions. There may have been other interpreters who differed in their explanations from the latter, and referred the suffix in ובבאה neither to Haman nor to Esther but to Mordecai, that is to say, that Haman's wicked device was frustrated when Mordecai came before the king and was installed as grand vizier, and would refer to the statement of our narrative: ' On that day did the king Ahasuerus give the house of Haman, the Jews' enemy, unto Esther the queen, and INordcai came before the king.' Though Mordecai's name is not mentioned in this connexion, it would not be syntactically wrong, as we could not expect "when Mordecai came before the king', since our author quotes in oblique narrative from Mordecai's letter who wrote ובבאי לפעי המלד 'when I came before the king'. May not this have been the meaning of a marginal note of some interpreter, אמר עם הספר ' he said in the letter', and there was no need to mention Mordecai's name ? ${ }^{46}$ To be sure, this is an awkward expression; but in a casual marginal note, we. ought not to expect elegance of style, and the interpreter may not have been a stylist at all. On the other hand, another interpreter thought like the Greek translator that the suffix in refers to Haman and expressed this interpretation in a marginal note, להמי 'it refers to Haman', while a copyist might have seen in this note an Aramaism for 'to excite them', and thus corrected it and inserted it

${ }^{46}$ Haupt (Critical Notes, p. 188 f.) correctly perceived the difficultics in the passages under consideration as regards אבצר עם הספר as a tertiary gloss. 
before חלאבדם שישב על היהודים לאבדם Finally, the first may be due also to a marginal note of some interpreter who thought that Haman's intention to destroy the Jews ought to have been mentioned before the casting of the lots. This is, of course, unnecessary, as Haman's hostility toward the Jews is expressed in the designation צורר כל היהודים 'the enemy of all the Jews '. However, though the passage under discussion in the Massoretic text is not original, and linguistically incorrect, the interpreter showed good exegetical sense, as Esther and not Mordecai was the main factor in frustrating Haman's decree. Nor did he accept the interpretation of the Greek version, though linguistically more correct, believing that Haman's fate was not due to the intention of executing Mordecai.

Esther 11. As to the etymology of the name of Purim, it has 26. already been pointed out that if the latter was etymologically connected with the name of the old Persian New Year festival Faravardig $\bar{a} n$, as contended by many modern scholars, the Jews adopted this name as that of their own festival for the purpose of disguising its very nature, as it could not be called by a name offensive to the Persians. The choice of an appropriate name for this day of commemoration both expressive of the events of that period, and not insulting to the religious sentiments of the Gentiles, was no easy task. A festival celebrating the victory of Monotheism over Polytheism would have constituted a continual menace to the existence of the Jews. For this reason, the real antecedents of the danger to the Jews are disguised in our narrative as far as possible. The same holds true to the name of Purim, though ostensibly identical with that of the Persian festival, to the Jews it was commemorative of their deliverance: 'They called these 
days Purim after the name of l'ur'. Considering it from this point of view, we may compare this festival to other Biblical festivals of the seasons, which may, indecd, date from a pre-Israelitish period, as assumed by many modern critics, and which the Israelites may have observed even before their descent to Egypt, but nevertheless assumed a different character in the religion of Israel, and became intimately connected with signal events in the history of Israel. ${ }^{47}$

However, though the real antecedents of the events of that period had to be disguised, there is an allusion at least to sufferings of the Jews that could not have been exclusively due to Haman's decree. This can be seen in the statement: "Therefore for all the words of this letter, and of that which they had seen concerning this matter, and that which had come unto them'. If we accept the current interpretation of our narrative, this statement would seem rather obscure and almost without any meaning. For if Haman's decree against the Jews was due to a mere freak for the purpose of wreaking his vengeance on Mordecai, and if the Jews had been permitted by Mordecai's decree to fall upon their enemies, and slaughter many thousands of them without being attacked, what did the Jews see concerning this matter, and what

47 The treatment of Purim by the higher critics is indeed not different from that of other Biblical festivals, since the critics who consider the stories of the Patriarchs in Genesis as merely legendary traditions partly. doubt and partly deny that the Israclites had ever lived in Canaan before their descent to Egypt. And even the historical character of the storics of Israel's sojourn in Egypt and their exodus is by many critics doubted, and by some denied altogether. Thus, in accordance with these views, it is maintained that the biblical festivals arc of Canaanitic origin, which the Israclites adopted after their entrance into Canaan, and that all the historical events these festivals are said to commemorate are later fabrications. 
did come unto them? They were merely for a short time, actually only for a few days, in danger of being exterminated ; but the danger having been averted, we cannot assert that the sufferings they experienced in mental anguish during this short period was, "what they had seen concerning this matter, and that which had come unto them'. But this statement will be viewed in a different light if we see in it an allusion to the religious persecutions the Jews suffered and witnessed prior to Haman's decree, and if we consider that even after Haman's execution and Mordecai's elevation the danger to them was by no means completely averted, and that though given a chance of fighting for their existence, their fate was still in the balance. ${ }^{48}$

Esther Ir. To those who accept the current interpretation of our $27-8$. narrative, the long description of the establishing of the Festival of Purim may seem tiresome and unnecessary. ${ }^{49}$ It reads as follows: "The Jews ordained, and took upon them, and upon their seed, and upon all such as joined themselves unto them, so as it should not fail, that they would keep these two days ${ }^{50}$ according to the writing

4* The reference to those events may seem somewhat cryptic. But the author could not have referred plainly to the persecutions the Jews had undergone on account of their religion, and could allude only to those events. He may have intended to say that the Jews accepted this festival not only to comply with Mordecai's request but also on account of their own experiences in the days of persecutions.

${ }^{19}$ The whole passage is gencrally considered an unncessary duplicate to IX, I9.

50 It seems that the actual observance of the Festival of Purim, which is limited to one day, is not strictly in accordance with this passage, unless we assume that the latter statement refers to both the inlabitants of the unwalled towns and of Susa, of which the former observed the fourteenth day of Adar, and the latter the fifteenth. But Susa was not the only city in which the latter day was observed, as the same is true also of the walled 


\section{thereof, and according to the appointed time thereof, every} year; and that these days should be remembered and kept

cities, whose inhabitants observed the same day. The Jewish tradition on this point is well founded, since the statement that the Jews of the villages, that dwell in unwalled towns, observe the fourteenth day of $A$ dar forces the conciusion that the Jews of walled cities observe the fifteenth. This is apparently confirmed by the Grcek version, which contains the addition : 'But those who dweil in the cities keep also the fifteenth day of Adar as a joyous and good day by sending dainties to their neighbours '. This is probably an unnecessary expansion, and not a part of the original Hebrew text. However, the Greek version seems to indicate that the inhabitants of the cities observe both days, the fourteenth and the fifteenth of Adar, and this would not be in accordance with Jewish custom and tradition. Furthermore, the term $\mu \eta \tau \rho \circ \pi$ ' $\epsilon \epsilon$, literally 'mother-cities', means capitals, and not walled cities in general. Thus the Greek version would seem to indicate that the Jews who dwell in capitals should celebrate Purim (also) on the fifteenth, commemorating thereby the events of the capital Susa. But the very statement that the divellers of unwalled towns observe the fourteenth shows that those of walled places observe the following day, and not merely those of capitals. This fact leaves little room for doubt that the addition in the Greek version is an illogical scribal gloss. The Rabbinical tradition on this point that distinguishes between unwalled and walled towns is linguistically and logically in conformity with the statement of our narrative. However, the passage under discussion which reads על כן היהורים הפרוזים היו"שבים בערי הפריות can scarcely be original. This has already been noted by Haupt and Paton, who consider the clause היו"טבים בערי הברוות which is an exact translation of an explanatory gloss. But the meaning of the latter term must have been well known, since the terms פרוץ פרוות פרון often occur in the Old Testament, and there was no need for an explanation of such a term. Therefore, may על על כי הידורים עי ה הפרסים היושבים בערי הפרוות the unwalled towns'? Now it has been pointed out that the observance of the Festival of Purim was obligatory only on those Jews and their descendants whose countries at that period formed a part of the Persian empire; and we have observed that the Egyptian Jews knew nothing of this festival, since Egypt was not a part of the Persian empire at the periof of these events see chapter I, note 6). May we not suggest that in the Alexandrian period, when the former extent of the Persian empire was not generally known any longcr, some copyist rightly abjected to the term こיסר:-, which would show that Purim was an exclusive festival of the Persian Jew and 
throughout every generation, every family, every province, and every city; and these days of Purim should not fail from among the Jews, nor the memorial of them perish from their seed'. But considered in the light of our interpretation, the observance of the Festival of Purim is of special significance for the Jews of all periods and of all - countries, even more than other biblical festivals. For the danger impending over the Jews in that period was not due to singular circumstances and conditions but to the fact that their religion had come into a conflict with the creeds of the Gentiles. The same danger that confronted the Jews in the Persian period was experienced by the Jews of many countries innumerable times, and is by no means past. As long as the Jews more or less adhere to their religion, the same conflict may arise again. It is certainly no exaggeration to declare that the Festival of Purim is intimately connected with the existence of 'the Jews', that is to say, the adherents of the Jewish religion. It is more their own deliverance the Jews commemorate on this festival than that of their ancestors in the days of Mordecai and Esther. The words of thanks: 'And this is which stood in good stead to our ancestors and ourselves; for not one alone hath arisen against us to exterminate us, but in every generation enemies are arising against us to exterminate us; but the Holy Onc, blessed be $\mathrm{He}$, is delivering us out of their hand,,51 are perhaps more appropriate for the Festival of Purim than for that of Passover, on which they are recited. The Rabbis, notwithstanding their erroncous conception of the events ehanged it into הפ, an emendation which might well have been suggested by the following clause היויטבים בערי הפרוות?

(1) See Hagadah-shel-Pesah. 
of our story, showed nevertheless, perhaps by intuition, $5: 2$ good historical sense in declaring: "If all biblical festivals should be abolished, the days of Purim will always remain. ${ }^{5: 3}$ The latter can disappear only when there should no longer be any conflict between the creed of the Jews and those of the Gentiles: with the disappearance of the Jewish religion. This is exactly what our narrative meant to indicate and to impress upon the mind of the Jews that the danger they escaped is not a matter to be forgotten, that their descendants and all such as joined themselves unto them, no matter in what country they might live, would be exposed to the same danger. The commemoration of this festival will be a comfort to them in their tribulations, strengthen their trust in the God of Israel, and save them from utter despair. The memorial of them will never perish from their seed as long as they continue to be 'Jews'.

However, notwithstanding the Jews had already ordained Esther rr. and taken upon themselves the observance of the Festival 29-30. of Purim, our narrative informs us: 'Then Esther the queen, the daughter of Abihail, and Mordecai the Jew, wrote with all authority, to confirm this second letter of Purim. And he sent letters unto all the Jews, to the hundred twenty and seven provinces of the kingdom of Ahasuerus with words of peace and truth.' This statement is rather obscure. The Festival of Purim having already

52 Though they based their saying upon the statement "These days should not fail from anong the Jews, nor the memorial of them perish from their seed', which they regarded as a prophetic prediction. Considering the matter in the light of our conception, the Rabbis were perfectly justificd in holding the Book of Esther in such high veneration sec chapter I, note 26 ).

53 אם כל השועדות יהיו בטלים ימי הפורים אינם נבטלים. 
been established and accepted by the Jews, what need was there for exhorting them to do so in a second letter? This evidently indicates that notwithstanding Mordecai's first letter, the Jews were by no means ready and willing to accept the observance of this festival, and Esther and Mordecai had to write 'with all authority' for the second time to confirm 'this second letter of Purim'. Even then it does not scem to have had the effect desired, as in verse 32 it is stated that 'the commandment of Esther confirmed these matters of Purim'. Why should Mordecai and Esther have insisted upon the observance of this festival? This was surely neither due to their ambition of being remembered as saviours of Israel, nor to their religious fervour. Furthermore, considering that the celebration of this festival did not encumber the Jews with special religious observances and mainly consisted of making merry, sending portions one to another and gifts to the poor, there does not seem to be any obvious reason for the persistent refusal of the Jews to accede to the demands of Mordecai and be averse to the acceptance of this obligation. And even if it had been an austere memorial day, it is scarcely conceivable that the Jews should have been opposed to the observance of so memorable an event. But a summary of the salient points in our interpretation of this narrative will make plain both the insistence of Mordecai and Esther on the commemoration of this event by the Jews and the reluctance of the latter to comply with this request.

The starting-point of our investigation was that the danger to the Jews described in the Book of Esther was of a purely religious nature, and was not due to the hatred toward their race, and that the antecedents of the main 
event of our narrative were the introciuction of anthropomorphic images of Anahita into the Zoroastrian religion and the proclaiming of this goddess as the representative of Ahuramazda, the supreme god of the Persians, her worship being enjoined on all inhabitants of the Persian empire. The main festival of this goddess evidently took place in the month of Adar. The Jews could not participate in the celebration of this festival and thus flagrantly defied the royal decree with regard to the worship of this goddess. The conduct of the Jews was naturally the cause of persecutions. The latter being without avail, it became evident that the resistance of the Jews was exclusively due to their religious conceptions. Having been given the choice either to give up their religion or to pay the supreme penalty for their disobedience to the royal decree, those Jews who did not want to part with their religion were in imminent danger of being exterminated. But duc to Esther's intervention they escaped, and through her influence the decree concerning the worship of Anahita was not enforced. However, the danger was still looming ahead, and there was no guarantee for the future, as some day the same trouble might start again and, as already observed, seems to have been the case under the reign of Artaxerxes III Ochus. This danger would have been minimized if the Jews could have seen their way to participate in the celebration of Anahita's festival without transgressing the principal tenet of the Jewish religion. Such a participation being tantamount to idolatry was out of the question. Since, however, Haman selected as the auspicious day for the execution of his decree the festival of Anahita, the latter, of course, synchronised with the day of their deliverance, and in establishing this day as the Jewish festival 
of commemoration, and it being celebrated in accordance with the Persian customs, there was outwardly not the least difference between the Persian and the Jewish festivals. Such a festival seemed a safeguard for the future, and for this reason Mordecai and Esther insisted upon its acceptance. Now it stands to reason that as far as the common Jewish people were concerned, they had no objection to the establishment of this festival. Our narrative thus correctly states that the Jews on receiving Mordecai's first letter readily and willingly acted accordingly and established the Festival of Purim.

However, the establishment of this festival could not but meet with fierce opposition on the part of the Sopherim. The latter could not countenance the introduction of a festival which to all appearances was identical with the idolatrous festival celebrated simultaneously, and was bound to become identified with it, when the cause of its origin should be forgotten. They could not but denounce Mordecai for its introduction. They did not fail to impress upon the mind of the people that all their sacrifices and the sufferings they had undergone were in vain, if after all they should have to pretend to worship Anahita. If this was the result of the deliverance, they could have saved themselves all the sufferings and persecutions by pretending to comply with the royal decree, as most of the Jews actually did. Little did the Sopherim care whether by the introduction of such a festival the danger to the Jews would be minimized. They were men of mettle, not deterred by any danger, and ready to lay down their lives at any time for the doctrines of their religion. The only danger they feared was that threatening the purity of the Jewish religion. They were, of course, in favour of estab- 
lishing a festival commemorative of the deliverance of the Jews, but a festival of specifically Jewish character, and not on the day of the idolatrous festival.

Convinced by the arguments of the Sopherim, the people reconsidered their resolution of establishing the Festival of Purim and abandoned its celebration. Thus Mordecai and Esther had to combat the influcnce of the spiritual leaders of Israel in this matter. In the end they prevailed and the people, partly grateful to them for the part they had played in the deliverance from the danger, and partly forced by Esther's decree, again accepted the Festival of Purim against the consent of the Sopherim. Therefore, it was a secular feast, without any religious character. $^{54}$ But many years later, when Purim had already been firmly established and generally celebrated, and thus there was actual danger that in the course of time its origin would sink into oblivion, and it would, indeed, become identified with the heathen festival, the Sopherim could not but re-affirm it, but at the same time recorded the reason for its celebration and ordained that the record should annually be recited on the day of this festival. The fact that the record was compiled in a manner not offensive to the Persians, and not exposing the Jews to any danger, seems to indicate that Mordecai's policy of safeguarding the existence of the Jews was not altogether ignored. ${ }^{55}$

54 The secular character of Purim can be seen in the fact that it is the only Biblical festival on which any kind of work is not prohibited. The Rabbis indeed observe ingeniously: 'Originally, in accordance with Esther 9. 19, Purim was intended as טוב טוב, in which work should be prohibited, but later in Mordecai's Letter of Purim, it was established merely as a "days of feasting and gladness", but not as בום (Negillah Babli, $5^{\mathrm{b}}$ )'.

55 Who knows whether the persecutions during the reign of Artaxerxes III 
Considering Mordecai's conciliatory policy of avoiding as far as possible any conflict with the Gentiles, the statement: 'And Mordecai sent letters unto all the Jews..., with words of peace and truth', acquires a special meaning. Peacc and Truth are, as a rule, contradictory terms. One who desires to live at peace with his fellow-men must not always insist upon 'the truth, the whole truth, and nothing but the truth'. Those who act according to this maxim are bound to come frequently into conflict with people and cannot live at peace. To be suré, it would be nothing short of moral turpitude to accommodate one's actions to the dictates of peace at the sacrifice of truth. But, as in other matters so also here, there is a just medium that lies between truth and peace. One whose first consideration is peace, but at the same time wants to act according to the dictates of truth, can do so by not proclaiming one's innermost thoughts. This was the policy of Mordecai: first 'peace', then 'truth'. He advised his co-religionists that in observing the Festival of Purim commemorating their deliverance simultaneously with the festival of Anahita, they would gain both Peace and Truth, though the latter would be disguised. There was no need for proclaiming openly the different character of their own festival. However, this was by no means the principle of the spiritual leaders of Israel, neither in that period nor later. ${ }^{j 6}$ But

Ochus did not render the Sopherim more tolerant on this point toward their opponents?

56 $\mathrm{May}$ we not contrast the principle of Mordecai expressed in the terms with the principle of the prophet Zechariah, in saying 'wherefore love ye truth and peace', and thus placing 'Truth' before 'Peace'? That this prophet regarded absolute truth as above all other considerations is evidenced from his exhortation in the same chapter, saying: "These are the things that ye shall do: Speak ye every 
Mordccai's conduct even before he was elevated to the office of grand vizier, was governcd by this principle, and later it naturally became the guiding rule of his policy.

But the second Letter of Purim, sent out by Mordecai Esther Ir. and Esther, is rather obscure. It reads as follows: "To ${ }^{3 \text { r. }}$ confirm these days of Purim in their appointed times, according as Mordecai the Jew and Esther the queen had enjoined them, and as they had ordaincd for themselves and for their seed, the matters of the fastings and their cry'. As far as the meaning of this passage is concerned, it is obvious: The Jews are exhorted to confirm the days of Purim in the same way as they had ordained for themselves and their seed the matters of fastings and their cry. It would thus seem that the Jews spontaneously had established fast days conmemorative of their suffering and their deliverance. The question now arises: to what Fast does this statement refer to? Certainly not to the Fast of Esther (תענית אפתר), which is observed on the day preceding the Festival of Purim, since this fast day had not yet existed in the Talmudic period. In the Halakic literature, as far as the present writer can see, it is for the first time mentioned about the middle of the twelfth century, by Rabbi Jacob Tam, ${ }^{57}$ who thought to have found an allusion

man the truth with his neighbour; exccute the judgement of truth and peace in your gates; and let none of you devise evil in your hearts against his neighbour' (Zecharial 8. I6, I7, 19 .

${ }^{57}$ See the commentary of Rabbi Asher (שירוש ה"רא" (Amsterdam, 1698. However, this Fast must have been established and generally known in the ninth century c. E., since Al-Berūni already referred to it (sce Lagarde's Purim). As a matter of fact, this Fast, though not yct known in the Talmudic period, must have been established not long atter the compilation of the Babylonian Talmud. There is an allusion to this Fast in the Tractate of Sopherim, the compilation of which is generally placed about $750-850$ c. E. This Tractate has the following statement: 
to that fast-day in the Talmudic statement: 'The thirteenth

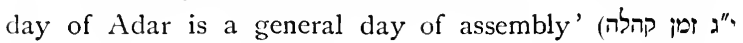
היאל הל This he explained: 'The people assembled themselves together on that day, because it was the Fast of Esther'. But this interpretation is not to be taken seriously, and is merely homiletic. The Talmudic passage under consideration meant to say, as Rashi, indeed, explains: The thirtcenth day of Adar was that day in which both

'Concerning Purim, the three days of the Fast are not observed conמני והמיישיד "y*y). Our Rabbis in Palestine, however, introduced the custom of fasting one day after Purim on account of Nicanor and his fellows' (Sophcrin, chapter I 7). The latter part of this statement is quite obscure, and we may doubt whether the text is correctly preserved, as the passage ונהגו להתענות seems to be omitted. The statement is quite clear as soon as we know that the Rabbis differed on the question whether 'the Good Days', enumerated in Megillath Ta'anith, on which fasting and mourning is forbidden, were still obligatory after the destruction of the Temple by Titus, and the Babylonian Talmud decided this question in the negative (Rosh Hashanah, $19^{\mathrm{a}}$ ). To 'the Good Days' belongs also the Day of Nicanor which was observed on the thirteenth of Adar. As long as its observance was obligatory, the Fast of Esther on that day was impossible. But in agreement with the decision of the Babylonian Talmud, the Babylonian Rabbis established this Fast on the day before Purim. This decision, however, was probably not accepted by the Palestinian Rabbis who still

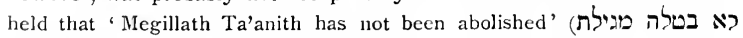
תענית), or may have held that 'the Good Days' enumerated there are still in force in the region where they had been originally established, but would not be obligatory in the diaspora. Thus they could not observe the Fast of Esther on the thirteenth of Adar, since it would collide with the observance of the Day of Nicanor, and instead of it fasted one day after the days of Purim. But while the compiler of Sopherim must have known of the Fast of Esther on the thirteenth of Adar, as explained, in the Talmudic period, there is no allusion either to the fast of three days, or to the thirteenth of Adar as the Fast of Esther, or to the fast after Purim. Thus the Rabbis of the Talmud did not see in דברי הצומות וחעקתם a reference to the establishment of fast days in memory of the fastings of Esther, and such an interpretation is post-Talmudic.

5* Megillah Babli, $2^{i}$. 
the Jews of Susa and of the provinces assembled themselves together for the purpose of defending themselves against their enemies, and therefore it is obvious that the Book of Esther may bc read on that day. Furthermore, if the Fast of Esther had been known and observed in the Talmudic period, we may rest assured that the Rabbis would not have merely alluded to it in that passage, but would have dwelt on it in the Tractate of MIigillah, and further would have distinctly numbered it among the Fast Days in the Tractate of Ta'anith. Notwithstanding this obvious fact, it is the consensus of opinion among conservative and modern commentators that the terms 'the matters of fastings and their cry', refer to the institution of the Fast of Esther. ${ }^{59}$ This interpretation, however, is by no means of recent date, as the same opinion was current among mediaeval commentators, as stated by Ibn Ezra in his commentary on the Book of Esther. ${ }^{60}$ That this passage, is indeed, obscure can be seen from the fact that even the Greek translator could not understand its meaning and therefore tried to cmend the text."1 Another interpre-

59 Siegfried, Wildeboer, \&c.

60 This was according to Ibn Ezra the current view among the mediaeval commentators (דברי הצוטות על דעת רבים על יום תענית אסתר. He, however, does not believe that the Sopherim had established this fast, saying: According to my opinion, our Sages established a fast day as a day of fear', that is to say. this would not be truc of the Fast of Esther commemorating the deliverance of Israel.

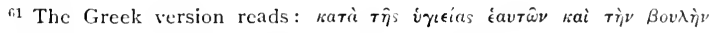

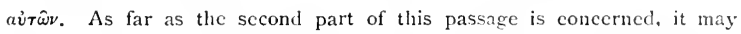
correspond to Hebrew בעצתם for original But it would be difficult to conceive that היצובות should have been misread to render the meaning ' according to their healthy state'. Jahn's rendering

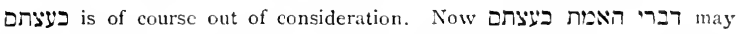

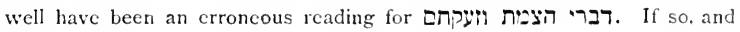


tation, quoted by Ibn Ezra, that our passage refers to the three days in which Esther and the Jews of Susa had fasted, and it means that the Jews had ordained upon themselves and their seed to do the same, and to fast on those days, is certainly beyond all consideration. On the one hand, it is scarcely conceivable that the Jews should have decreed for themselves and their descendants to fast three days consecutively. Such an ordinance would surely fall under those which the Rabbis designated 'ordinances

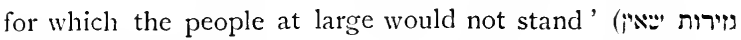
(רוב הצבור יכולין לעמור בהם may surely credit the Jews of that period with so much good sense as not to have ordained anything of that sort. ${ }^{62}$ On the other hand, it does not stand to reason that the Jews of that period should have changed the first two days of Passover into fast-days. To be sure, there is no reason why they should not have transferred these fast-days to some other date so as not to collide with the Festival

considering that the translator relied upon his memory in making his transרברי עלום ואטות בעצתם lation, may we not venture to suggest that he read

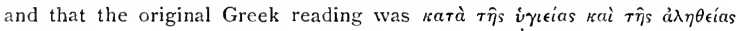

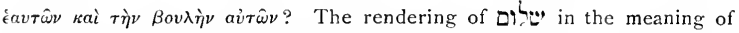
'health' with ífieta is very probable, but it does not stand to reason that the translator misread של for של for.

62 This interpretation is by Ibn Ezra ascribed to the Karaites, saying:

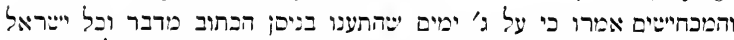
'And the Disbelievers are saying that the passage refers to the three days which they fasted in Nisan, and therefore all Israelites ought to fast in the same way forever'. But it seems that the same interpretation was held by some of the Rabbis, and not only by the Karaites, as seen in the Tractate of Sofhcrim, quoted note 57. However, as in other matters so also on this point, the Rabbinical interpretation was more rational than that of the Karaites, which required to fast three days consecutively, while the former was satisfied with the fasts of three separate days. 
of Passover, and they might have established only one fast-day commemorative of the fast of Susa. But, if this fast-day is not identical with the Fast of Esther, it would seem strange that it entirely disappeared without having left any vestige behind it in the Talmudic period. Thus, if we do not want to assume with the Greek translator that our text is corrupt, there is no other way out of this difficulty than to see in our statement a reference to the Four Fast-Days. This is, indeed, Ibn Ezra's own interpretation of our passage, saying: 'The matters of fastings refer to the Fast-Days mentioned in the Book of Zechariah, and our passage means to say that the Jews should ordain upon themselves to rejoice in the days of Purim just as they had ordained for themselves to fast in their days of mourning, when the City was taken and the Temple was burned, since no prophet did command them to fast'. ${ }^{63}$ However, if the Festival of Purim had been established by the spiritual leaders of Israel, and they surely had no less authority to issue ordinances than the former prophets, there was no need for referring to a precedent to authorize the establishment of this festival. Thus, our statement in the light of this interpretation bears out the contention that the Sopherim actually refused to have anything to do with the introduction of this festival, and shows further that Mordecai and Esther did not have any authority for introducing any religious festival. But the Jewish pcople themselves could not be prevented from accepting it voluntarily by common consent. The question now arose, whether the people themselves possessed the authority for

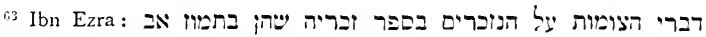

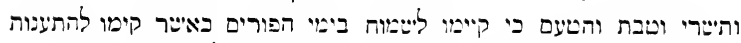

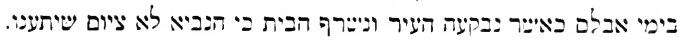


imposing the observance of this festival upon future generations. This question is answered in the affirmative, and the action of the people in this matter is justified by a precedent: It was not for the first time that the people by common consent imposed observances that had been recognized as legal and binding for later generations. Ibn Ezra is certainly correct in declaring that the four FastDays mentioned in the Book of Zechariah had not been instituted by the prophets. When, after the return from the captivity, this prophet was asked: 'Should I weep in the fifth month, separating myself, as I have done these so many years?' His answer was: 'When ye fasted and mourned in the fifth and in the seventh month, even these seventy years, did ye at all fast unto Me, even to Me? And when ye eat, and when ye drink, are ye not they that eat, and they that drink?' 64 Now there is no room for doubt that the prophet would have treated these institutions of fasting with greater reverence, if they had been established by the prophets. But they had been established by the people themselves without consulting the prophets of that period. And it is, indeed, doubtful whether the prophets would have given their consent to the introduction of these fast-days, as also in pre-exilic times Israel observed fast-days, which were by no means conducive to real repentance and did not have any influence upon the moral condition of the people. ${ }^{65}$ We may perhaps suggest that

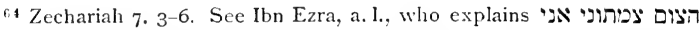
Behold I have not commanded

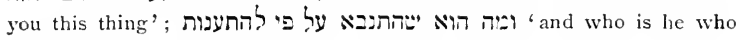
קהגי ינויתי : 'Did I command you to fast?'

65 We find even queen Jezebel proclaiming a fast ( 1 Kings 21.9 ), and such fasts scemed to have been customary even among idolators. See alsoJer. 36.9. 
the establishment of these fast-days was not for the purpose of repentance, but for keeping in the mind of the exiles the national consciousness and the remembrance of their country, and thus were scarcely of religious significance. Thus, being merely national institutions, they could not have any influence on the religious conceptions of the people, and the prophets could neither lend their authority for their establishment nor look with special favour upon their observance. But, when the idea of a Jewish nationality gave way to that of a Jewish religious community, as pointed out in Chapter $\mathrm{V}$, the fast-days, originally national, assumed likewise a religious character, and therefore their establishment was recognized as binding for future generations. The recognition of their establishment, whatever the reason for its validity may have been, established a precedent for the people to impose the Festival of Purim on later generations without or against the consent of the Sopherim.

However, though the Jewish people at large had volun- Esther Ir. tarily established the Festival of Purim against the consent 32. of the Sopherim, it stands to reason that there were still a good many who for religious reasons refused to recognize its validity and ignored this festival. The conduct of the minority frustrated the main purpose of this festival to be a safeguard against future persecutions, and the majority of the Jews had no legal right for coercing their coreligionists to their will. This festival had to be confirmed by a royal decree. For this reason 'The decree of Esther confirmed these matters of Purim'. Now Esther, whatever her rank may have been, could not have possessed any authority for issuing decrees in her own name. A decree was binding only if 'written in the king's name and sealed 
with the king's ring'. But this she could not have done without obtaining the king's consent. This she surely did, and the king could not but be pleased with Esther's request to impose upon the Jews the celebration of the fourteenth of Adar which was the day of the Persian festival, and authorized her to issue a royal decree to that effect. ${ }^{66}$

Esther having issued the decree, 'it was written in the book'. This statement is not quite clear. The term in our narrative means either 'letter' or 'book'. The former meaning is scarcely conceivable, as a statement that Esther's decree was sent out in the form of a letter would be gratuitous; and it surely cannot mean that Esther confirmed the matters of Purim orally, and afterwards her command was written down in a letter, as an oral command would not be legally binding, as already pointed out, unless 'written in the king's name and sealed with the king's ring'. But the latter meaning would be likewise difficult, as our statement cannot mean to say that 'the matters of Purim' (דברי פורים) were written down in a book, since it would be grammatically incorrect. Nor can it mean that the decree of Esther contained the whole

${ }_{66}$ Thus the Festival of Purim would be in this respect similar to all the Biblical laws which had been made obligatory upon the Jews by a royal decree of Artaxerxes given to Ezra (Ezra 7. 25, 26). Now it has been pointed out in chapter VIl, note 59, that there are good reasons for the assumption that Ezra was a contemporary of Mordecai, and not of Nehemiah, and if so, the same king Artaxerxes II confirmed by a royal decree both the Biblical laws and the Festival of Purim. Ibn Ezra expressed a similar opinion concerning the necessity of confirming this Festival by a royal

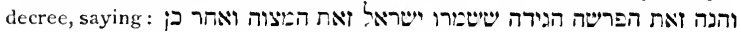
וכhis passage indicates that Israel had observed this commandment, but afterwards gave it up, and therefore Mordecai was in need of Esther that she should write letters concerning it as queen'. 
story of the origin of Purim and this was written in a book, as the copies of Esther's decree sent out everywhere would be sufficient for this purpose, and such a statement would be superfluous. The old interpretation that this statement refers to the present Book of Esther, ${ }^{67}$ is, of course, impossible, since it intrinsically shows that it was not compiled during the life-time of Esther, as we shall further see. However, our statement may refer to a certain book in the archives where Esther's decree was recorded, and due to this fact the Festival of Purim was imposed upon the Jews as a Persian law for future times. This seems to have been the meaning of the Greek translator

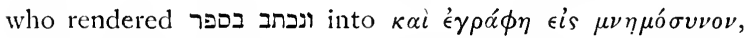
'and it was written as a memorial', which may mean that it was recorded in 'the Book of Records' (ספר הזברונות = $\gamma \rho \alpha ́ \mu \mu \alpha \tau \alpha \mu \nu \eta \mu o ́ \sigma v \nu \alpha)$.

Due to the current identification of the king of our Esther Ir. narrative with Xerxes, the statement that 'the king Ahasuerus laid tribute upon the land and upon the isles of the sea', appeared to all modern commentators as a trivial remark which evidently has not the least connexion with the preceding events. Yet the author must have well known what he was talking about, and thus this statement must be closely connected with Mordecai's elevation to the rank of grand vizier. This passage is, indeed, one of the proofs against the identification of Ahasuerus of our story with Xerxes, as pointed out in the third chapter. Ibn

67 So Rashi and the current Rabbinical interpretation. Paton's reference to Exod. 17. 14 ; Numb. 5. 25 ; Job 19. 23, to show that merely means : 'it was committed to writing', does not help us in explaining this statement, since Esther's command was already committed to writing as a decree. 
Ezra is the only commentator who clearly perceived that our narrative could not have meant to state that the king laid tribute upon the dominions which formed a part of the Persian empire long ago, but on those which were recently conquered. This interpretation is, no doubt, correct. But if the king of our story should be identified with Xerxes, this statement would not be true, as from the pages of history we know that Xerxes did by no means increase his empire by new conquests. On the other hand, if our statement is true, the current identification of our story must be wrong.

Now according to the principle of justice, a good action deserves a reward. No story is complete in which this principle is ignored. In reviewing the persons who played the principal parts in our narrative, we find that Haman received his due for his crime against the Jews, Mordecai was rewarded in being elevated to the rank of a grand vizier, and Esther for her efforts in behalf of her people ruled supreme as queen. But after all, the main factor in the deliverance of the Jews was the king, and in what manner was he rewarded? Therefore, our narrative informs us that the king did not remain without a reward either. Mordecai's elevation was to his royal master's advantage, as he was a very able statesman and conducted the affairs of the empire in a masterly fashion. Due to his diplomatic skill, the sea-land and the isles of the sea, that is to say, the Greek cities of Asia Minor and its islands, which Xerxes, the great-grandfather of Artaxcrxes II, had lost about eighty years ago, again became tributary to the Persian empire. This event, the greatest achievement in the Persian period, occurred in the year $3^{8} 7$ B. C. E., five years after the events narrated in the Book of Esther, thus 
at the time when Mordecai stood at the head of the Persian government. In accordance with this interpretation, we

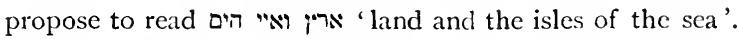
The geographical term ארין הים, corresponding to cuneiform Māt-tamtim, 'Sealand', refers only to the Greek citics situated at the seaboard, as those situated in the interior of Asia Minor were in all probability subjected before the Peace of Antalcidas. ${ }^{68}$ In dealing with events under the reign of Artaxerxes II, though not intending to deal with Persian history, the author could not have omitted to mention the most important event in the Persian history that occurred under the reign of this king, especially as this achievement redounded to the glory of Mordecai who as first minister conducted the negotiations with the Greek ambassadors. If the author had not referred to this event, we might have reason to doubt whether he was thoroughly acquainted with the historical events of that period, and thus question his reliability concerning other statements. Thus, the passage under discussion is far from being a trivial remark, but on the contrary of signal importance, as it bears testimony to both the identity of the king of our narrative and to the author's thorough acquaintance with the historical events of the period of Artaxerxes II. If, however, the author had meant to say that the king laid tribute upon all dominions of his empire indiscriminately,

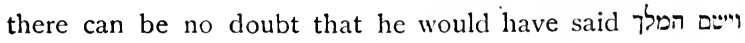
אחשורש מס על כל מדינות מלכותו "and the king Ahasucrus laid a tribute upon all the provinces of his kingdom'.

Having pointed out one signal success of Mordecai as Esther 10. grand vizier of the king, the author goes on to say that he was likewise successful in all his acts which, however, 
have no connexion with our narrative, and can be found recorded in the Persian historical annals, saying: 'And all the acts of his power and of his might, and the account (פרטת) of the greatness of Mordecai, how the king advanced him, are they not written in the book of the chronicles of the kings of Media and Persia?' The term פרט, which literally means 'interpretation, explanation', used in this connexion, is of special significance. Our author does not mean to say that the greatness of Mordecai is recorded in the royal chronicles. He was a real historian, and he well knew that the royal chronicles could not dwell on the merits of a minister who was, after all, merely an instrument in the hands of his royal master, even if he had been one of the highest grandees, as such special praise would overshadow the glory of the king, and deprive him of all credit for the signal achievements of his reign. If Mordecai's name was mentioned there at all, it could only have been incidentally in connexion with achievements of the king. Now it would be a truism to say that glorious deeds of many kings on which their fame rests were not due to their own personality but to that of their ministers. This is especially true of the king of our narrative, who was weak, capricious, readily accessible to personal influences, and dependent upon his favourites. His achievements during the period in which Mordecai served as his grand vizier, if rightly interpreted, testified to the greatness of the latter. Furthermore, many of the events recorded in this narrative seem obscure and unexplainable if we do not know the historical events of that period. Our author was well aware of this fact. However, he could not refer to the conflict between the Persian and Jewish religions, the real background of those events which brought about 
Mordecai's elevation. Therefore, he states that 'the explanation for the greatness of Mordecai' can be found in the royal chronicles which deal with the historical happenings of that period. ${ }^{69}$

The eulogy of Mordecai in this passage is in itsclf a sufficient proof that the Book of Esther, in the present form at least, could not have been written during his lifetime. The present Books of Ezra and Nehemiah were not written by these men to whom they are traditionally ascribed, but were compiled from their records. And the same holds true, to a certain extent, of the Book of Esther. The original documents underlying our narrative were the letters sent out by Mordecai, and the decree of Esther. In these letters Mordecai had given an account of those events, without referring, of course, to the main conflict at the bottom of the danger impending over the Jews. This account, being in the style of a letter, in which most probably, like Ezra and Nehemiah, Mordecai spoke in the first person, as already suggested above, was called 'The Letter of Purim' (אגרת הפורים). This document, but for the main event, had not the least resemblance to our present narrative, ${ }^{70}$ which is not written in the style of

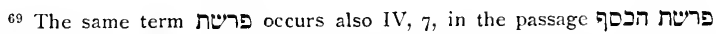
אישר אבר המן לשקול explained by the commentators, but is also here to be taken in the meaning of 'explanation'. It has been pointed out that Mordecai's intention was to impress upon Esther the significance of Haman's offer: the property of the Jews being given to their adversaries, Haman was sure of accomplishing his purpose.

${ }^{70}$ In this letter there was no need to inform them concerning the personalities of Ahasuerus, Mordecai, and Esther, and the story of Vashti was quite unnecessary. Even assuming that these mattcrs were mentioned in the letter, since it was int ended as a record for futurc generations, which does not seem probable, the second part of the ninth chapter could certainly not have been written by Mordecai himself. 
a letter. The compilers of our narrative lived in all probability toward the end of the Achaemenian period, as already mentioned above, yet at a time when the characters of Mordecai and Esther, and all those events were still well known. Who knows whether the persecutions the Jews underwent under the reign of Artaxerxes III, the cruel successor of Artaxerxes II, which were evidently due to the resurrection of the decree concerning the worship of Anahita, and the experiences that the institution of Purim actually minimized the danger to the Jews at that period, did not incline the Sopherim toward a more lenient attitude in respect to this festival? But if so, the necessity of sanctioning it and giving it a religious character became of paramount importance. Furthermore, the reference to the Persian chronicles seems to indicate that our narrative was written during the Persian period. ${ }^{71}$ For after the passing of the Achaemenian dynasty, the Persian annals do not seem to have existed any longer, as historians would have quoted them if they had still existed. The statement of the Zend-Avesta, that the Persian books had been destroyed by Alexander the Great, is certainly well founded, ${ }^{72}$ as these records having been written on

71 Paton's view that the author is probably thinking of some Jewish History that gave from a Jewish point of view the history of the kings of Media and Persia (p. 304), is not to be taken seriously.

${ }^{72}$ Cf. Jackson, Zovoaster, p. I34, and Darmesteter, Zend-Avesta, p. xxxii. Though this statement refers only to the Sacred Books, the same is true of the Persian archives. Alexander may or may not have intended to destroy the Persian library. He was too strongly imbued with the Greek conceit to give any attention to the books of the barbarians. But he surely intended to destroy the Persian royal residences as retribution for the destruction of Greek cities and temples in the campaigns of Darius and Xerxes. And in these conflagrations, the Persian archives could not escape destruction. The only Persian records that survived were those engraved on stone. 
a perishable material could not have escaped destruction when this king burned down Persepolis, Ecbatana, and other Persian capitals.

However, it is exceedingly doubtful whether the name of Mordecai ever occurred in the Persian annals, as there is scarcely room for doubt that among the Persians he had a pure Persian name. While the Jews of the Persian period knew the Persian name of the Jewish grand vizier who played such a signal part in their deliverance, and thus could identify his name in the Persian annals, for later generations such an identification was nigh impossible. The Greeks who conducted negotiations with Mordecai had not the least notion that he was not a native Persian. It is even rather doubtful whether the very existence of a Jewish people was known to them, though some lcarned Greek traveller may have made their acquaintance about that period. ${ }^{73}$ But the fact that we do not know Mordecai's

73 According to Clcarchus of Soli, the disciple of Aristotle, the latter had met a Jew concerning whom he said: "The man was by race a Jew out of Coele-Syria. His people are descendants of the Indian philosophers. It is reported that philosophers are called Calani among the Indians, and Jews among the Syrians. The Jews take their name from their place of abode which is called Judaea. The name of their city is very difficult; they call it Hierusaleme. This man, then, having been a guest in many homes, and having come down gradually from the highlands to the sea-coast, was Hellenic not only in speech but also in soul. And as we were staying in Asia at the time, the man cast up at the same place and interviewed us and other scholars. But inasmuch as he had come to be at home with cultured persons he imparted more than he received' (Josephus contra Apionem, I, 22, I 79. Megasthenes also describes the Jews as the philo-

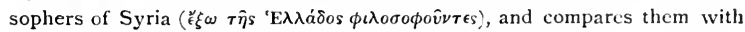
the Brahmins in India (Clemens Alexandrinus, Stronata I, 15, 72). Hart in his article 'Jews', Encyclop. Brit., observes that there is no reason to doubt the probability or even accuracy of the narrative of Clearchus. These ideas concerning Judaism dating from a period when the Greeks had already come in contact with the Jews, after the downfall of the Persian empire, 
Persian name, and we are thus unable to identify him with a certain Persian grandee whose name may be known, does not cast any doubt upon our author's statement that he played so important a part in the Persian history. We may point out the fact that tradition is vague and contradictory concerning the real names of Smerdis and PseudoSmerdis, though their historical characters are beyond any shadow of doubt. The former is called by Darius, in his Behistun-Inscription, Bardy $a{ }^{74}$ the latter Gaumata; ${ }^{75}$ both in Babylonian Barsia, ${ }^{76}$ by Aeschylus, Mardus, ${ }^{7 \pi}$ by Herodotus, Smordis; ${ }^{78}$ the former is called by Xenophon ${ }^{79}$ and Ctesias ${ }^{80}$ Tanjoxarces, by Justin ${ }^{81}$ Oropastes; the latter by Ctesias Sphendadates. The same may hold true of the names of Mordecai, Esther, and Haman.

Esther 1o. The culogy of Mordecai is fully in agreement with our 3. conception of his character. He was pre-eminently a man of peace. This principle governed his whole life. Peace with all the world he considered the acme of human felicity. This thought he expressed in his Letter of Purim: 'Words of Peace and Truth'. Peace was his first consideration when the latter was not contrary to the principle of Truth. But as soon as these two principles came into leave no room for doubt, that as a rule, the Greeks of the first half of the fourth century B. C. E. knew almost nothing about the Jews.

74 Behistun-Inscription, Col. Io.

75 Ibid., Col. I, I I.

76 See Talquist, Neubabylonisches Namcnbuch.

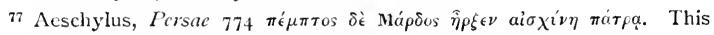
Greek poet, born 525 B.C. E., was actually a younger contemporary of Pseudo-Smerdis.

is Herodotus, III, 6r, \& $\mathrm{c}$.

79 Xenophon, Cyropacdia, VIII, 7 .

so Ctesias, Persica, 8-13. For the name Sphendadata of the usurper see chapter VI, note 26.

\$1 Justini Historia, I, 9. 
collision, he did not hesitate to sacrifice his own happiness for the sake of truth, as he did in his conflict with Haman. Though not having been in sympathy with the zeal of the strict adherents of the Jewish religion, neverthcless he was willing to expose his own life for their sake, and fully identified himself with his brethren who sacrificed themselves for the truth of their religion. The establishment of the Festival of Purim commemorating the deliverance of the Jews from Haman's decree, though ostensibly identical with the Persian New Year Festival, was principally due to his desire of avoiding friction with the Gentiles, and to maintain both Peace and Truth. He certainly was solicitous for the welfare of his people, and aimed to safeguard their existence, and to insure for them the blessing of peace. This is, indeed, the ideal of Israel, as the Psalmist expressed himself: "The Lord will give strength unto His people; the Lord will bless His people with peace' (Ps. 29. 1I). Peace was the theme on which Mordecai dwelt, and which he recommended to his descendants as the highest good: 'He was seeking the good of his people and speaking Peace to all his seed'. 



\section{GENERAL INDEX}

\section{I}

Abali.Nabū (= Abednego), $\mathbf{1} 88$.

Abednego, ibid.

Abihail(Esther's father), 106, 277.

Abnu (=pur), 163 .

Aboe (temple at), 39 .

Abraham, 104, 172, 188, 189.

Achaemenian, Achaemenides, 50,

$74,75,76,77,98,122,128,231$, 235, 296.

Adad (deity), 92.

Adar (month of), 165, 168, 169,

179, 232, 244, 254, 259, 261, 274.

Adiabene, 157.

Aeschylus, 70, 298.

Africanus, Julius, 7 .

Afrudsha (pr. n.), 70.

Agag (king of Amalek), 2 I-4.

Agagite, 21, 24, 26.

Agesilaus (king of Sparta), 52, 236.

Aghrimat-teira (pr. n.), 70.

Ahriman (god of darkness), 37 .

Ahuramazda (supreme Persian god), 39, 70, 98-101, 118,120 , 1 24, 1 26, 138, 143, 238, 249.

Akilisene (temple of Anahita at), 127.

Al-Berūni, I66, I67, 283.

Alexander the Great, 75, 234, 296; son of Amyntas of Macedonia, $62, \mathrm{I} 5 \mathrm{I}$.

Alexandria, 260, 26I.

Alexandrian Age, 13 , 107.

All Souls' Feast, I67.
Altorientalische Forschungen ( $\mathrm{H}$. Winckler), 82, Ió5.

Alt persische Keilinschriften (Weissbach und Bang), 119.

Amalek, 112.

Amalekite, 21, 24, 25, 29.

Amarna (Letters of), 26.

Amasis (king of Egypt), 69 .

Amestris (wife of Xerxes I), 30, $34,62,100,200$.

(daughter of Darius II), 232.

(daughter of Artaxerxes II), 49.

(wife of Artaxerxes II = Esther?), 50.

Amirchiand (pr.n.), 70.

Am-ma-an-ka-si-bar (Elamitic deity), 28.

Ammonites, 24.

Amphictyonic Council, 121.

Amshaspands (= angels), 99.

Amurru (Clay), 90.

Amyntas (king of Macedonia), 62 ,

151 .

Anabasis (Nenophon), 57.

Anadates (sanctuary of), I29.

Anahita (the highest among the

Amshaspanals), her images erected in all centres of the Persian empire, I19-20, 134 ; represented as manifestation of Ahuramazda, 125-6; her worship made compulsory as Persian law, 125-6; its spread, 127-9; refused by the strictly religious Jews, 130-2; her festivals, I33, 
I65-9; erection of her image in I) urilu (centre of Anu and Ishtar), $136-8$; incompatibility of her worship with the Jewish creed, I59; her festival the time of the execution of Haman's decree, I67-9; it synchronized with the day of the deliverance of the Jews, $278-83$.

Anaitis (= Anahita), 46, 129.

Ananikiam, H. M., 99.

Anat-Mylitta (= Anahita), 128.

Anarim, 88.

Angels (identified with the Planets), I6I.

Anra-Mainyu (= Abriman), 100 , IOI.

Antalcidas (Peace of), 42, 53, 293. Ante-dating, 56.

Antiochia, 260 .

Antiochus Epiphanes, 13, 36, 118 , I 3 I, I 59, 228.

Antipater (father of Herod king of Judea), 22.

Antiquities of the Jews (Flavius), $6,7,25,157,252$.

Anu (supreme Babylonian god), I 25,138 .

Aphrodite (= Anahita), I 26, I34. Apion(Josephus Contra Apionem), I 33.

Apocryphal Additions (to the Book of Esther), 5, 6, 109.

Apollo (temple of), 39 .

Apollodorus (pr. n.), 105.

Apollonius (pr. n.), 105.

Arad-Gula (pr. n.), I05.

Arakiel (angel), I62.

Aramaic, $8 \mathbf{2}, \mathbf{I} 88$.

Araynta (niece of Xerxes I), 200.

Arabians, 249.

Ardashir (= Artaxerxes, founder of the Neo-Persian empire), 52, I 4 I.
Dirazdast (=Artaxerxes I), 1 28).

(= Artaxerxes II), I29.

The Kayan (= Artaxerxes I', I 28 .

Ariaspes (son of Artaxerxes II), 49. Aristotle, 297.

Armenia, 26, 99, 127, 167 .

Arrian, 75 .

Arsaces (founder of the Parthian empire), 75, 79 .

Mithridates (conqueror of Babylon), 76 .

(name of Artaxerxes II before his accession), 78,79 .

Arsacides (Parthian dynasty), I 5 , $42,50,76,163$.

Arses(successor of Artaxerxes III), 75,77 .

Arshu (= Arsaces, Babyl. name of Artaxerxes II), 77, 78.

Arsicas (= Arsaces, name of Artaxerxes II), 77, 78 .

Artashatr ( $=$ Neo-Persian Ardashir), 52.

Artaxata (temple of Anahita at), I27.

Artaxerxes I Longimanus, 47, 51, 77, 78, 80, 128, 129, I 72 ; II Mnemon (= Ahasuerus), the description of his life by Plutarch, 43-50; his character and influence on Greek affairs, 50-4 ; his victory over his brother Cyrus, 54-8; his domestic affairs, 58-73; identical with Ahasuerus, 73-4; his fictitious name in the Hebrew text, 74So; his introduction of anthropomorphic images into the Zoroastrian religion, and the establishment of the worship of Anahita as a Persian law, I 1930 ; the persecution of the Jews 
due to his law, I $30-8$; the conspiracy against his life, I 4952; his conduct under the influence of wine, 215-7, 227.

III Ochus, 29, 77, 228, 236, 279,281 .

Artemis (= Anahita), I 25 .

Aryan, 28, 78 .

Ashur (deity), 98.

Ashurbanipal (king of Assyria), 28 .

Asia, 52, 180 .

Asia Minor, 3 I, 4I , 52, 53. 74, I 80, 228.

Aspasia (concubine of Cyrus the Younger), 46-8, I 49.

Aspects of Religious Belief and Practice (Jastrow), 160.

Assyria, 91, I 35.

Assyrian Personal Names (Talquist), IO4,

Assyrians, 91, 98, 135.

Aste (clement in Persian proper names), 70.

Astarte, Astartes, 82, 92.

Asta-teira (= Washta-teira), 70 .

Astrologers, 16I.

Astrology (= idolatry), I6o, I62.

Astronomy, I6I.

Athenian, 39, 53.

Athens, 52.

Atossa (wife of Darius the Great), 32.

(daughter of Artaxerxes II), 47,49

(wife of Artaxerxes II, jdentical with Hadassah ?), 50.

$(=$ Hutaosa $=$ Hadassah $?)$. 106.

Avesta(-Zend), 98, 99, 128, 129, $163,296$.

Azariah (= Abed-nego), I88.

Azri-Jau (king of Ja'udi, \&2.
Baal, Baalim, 82, 92.

Babylon, Babylonia, 16, 38,56 , $60,76,88,90,92,97,103,105$, $107,134,136-8$.

Babylonian chronology, 56 .

Babylonian Expedition of the University of Pennsylvania, 105.

Babylonian Pantheon, 121, 125; Babylonians, I 35, 142.

Bactria, I 34, I8o.

Baeshat-teira (pr. n.), 70.

Baga (= God), 23, 27.

Baga-datha (pr. n.), 27 .

Bagaeaus (pr. n.), 23.

Bagoan (= הבגי (בגו), 23.

Bagoi (= בבגור), 27.

Bagopates (pr.n.), 23.

Bagophanes (pr. n.), 23.

Bagosaces (pr. n.), 23.

Bagoas (prime minister of Artaxerxes III), 23, 29.

Balati-shar-usur (= Belteshazzar), I 88.

Baraitha, I64.

Barakiel (angel), 162 .

Bardya (= Smerdis), 298.

Bar Hebraeus (Chronicle of), 73, 74.

Barzia (= Smerdis), 298.

Batten(InternationalCommentary on Ezra-Nehemiah), I70, I72.

Behistun Inscription, 29, 101, 129, 168, 173, 298.

I $\mathrm{ēl}=$ Marduk, 97 .

Bèlit-ilani (= Anahita), 125.

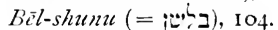

Belteshazzar (Chaldean name of Daniel), i 88 .

Beltis (= Anahita), 134 .

Benjamin (tribe of), I8, I 9.

Benjamite, I6, I8, 21, 26.

Berossus (priest of Bēl), 99, I I9, I 28, I 33 .

Bertheau, E., 10. 
Bertheau-Ryssel (Commentaries on Esther and Ezra-Nehemiah), 19, 30, 32, 40, 66, 167, I80, 222, 267.

Bigthan (eunuch), I 50, 207.

Bilshan (= Bél-shunu), 104 .

Bleek, F., 259.

Boghaz-köi (excavations of), 28.

Brahman Yasht, I28, 129.

Brahmins, 297.

Bretons, 90.

Brown-Driver (Hebrew Lexicon), 23 I.

Brünnow, R., 163 .

Business Documents of the Persian period, I3I.

Cabbalistic (literature), 92.

Cabbalists, I07.

Cadusians (campaign of), 45, 72 .

Calani (= philosophers among the Indians), 297.

Caliphs, I22.

Cambyses (king of Persia), 40, 77, 94, 122, 216, 23 I.

Canaan, 262, 273.

Canaanitic, 273 .

Canon (fixing of), 1 5, 79.

Canticles (liook of), I I 5 .

Cappadocia, I 27.

Cappadocian (language), 129.

Carthage, 35 .

Carthaginians, 35 .

Cassel, Paulus, I I, 17, 24, 25, 27, $40,69,86$, го6, I29, 149, 178, I 85,25 I, 266, 267.

Casting of the Lots (Purim), I60, 162-4.

Caunian, 235.

Chaldean, I05, 136, I88.

Childlessness, I87-9.

Chorasmians, I68.

Christian Era, 156.
Hierarchy, 56.

Christianity, 36, 100, '128, 16I, 228.

Christians, 86, 89, 90, 104, 119 , 123, 161, 242, 252.

Christmas, I 66.

Circumcision, 249.

Cilicia (worship of Anahita at), 127.

Clay, A. T., 28.

Clearchus (commander of Cyrus'

Greek mercenaries), 6I, 70.

(of Soli, disciple of Aristotle), 297.

Clemens Alexandrinus, i 28.

Cleopatra (queen of Egypt), 5 .

Cnidus (battle of), 53 .

Code of Hammurabi, I 89.

Coele-Syria, 297.

Colophon, 43.

Conon (Athenian), 53.

Constellations, 160 .

Cornill, Io.

Craterus (one of Alexander's generals), 234 .

Critical Notes on Esther (P. Haupt), 2 S c.

Ctesias (of Cnidus), 34, 43, 44, 48, 57, 58, 6I, 69, 70, 77, I4I, I 58, 232, 298.

Cunaxa (battle of), 46, 56, I50, I 58, I90, 235 .

Cuneiform Inscriptions, I19, 126. Curtius (Ilistory of Greece), 38 .

Cybele (amalgamated with Anahita), 127.

Cyrene (the Jewish rebellion), I 72 .

Cyropaedia (Nenophon), 179.

Cyrus the Great, 33, 37, 38, 77,

$97,216,232$; the Younger (rebellion of), 42, 44, 46, 48, 54, $55,55,57,59,60,63,73,141$, 149, 158, 189, 215, 216, 227, 228. 
Daēa'as (Iranian gods), 99, 125, 128.

Damascus (temple of Anahita at), 120.

Daniel (Book of), 30, 108, 116, $136,137,138$.

Darius I, 29, 3I, 33, 34, 38, 52, 54, 72, 77, 101, I 58, 231, 296.

II Notus, 44,5 I, 56, 78 .

III Codomanus, 7I, 75 .

son of Artaxerses 1I, 46, 47, $48,49,51,23 \mathrm{I}$.

Darmesteter, J. (Zend-Avesta), 99, I $28,129,141,163,296$.

Date of Zoroaster (Jackson), 141.

David (king of Israel), 21 .

Kimhịi (Biblical commentator), 288 .

Deborah (prophetess), 262.

Declaration of Independence of the American Colonies, 229.

Defilement of the hands, I 5 .

Deinon of Colophon (Greek author', 43. 44, 45, 46, 77 .

Delitzsch, Friedrich, 33 .

Delphos, 39.

Demeter (= Anahita), 125.

$\operatorname{De} r(=$ Durilu $), \mathbf{3} 37$.

Deuteronomy, I 12, I 13 .

Dieulafoy, M. (French archaeologist), 73 .

Dillmann, 26.

Diodorus Siculus, 52, 53, 57, 71, $155,160$.

Divination, I60, 162, 164, 169.

Doricha (real name of Rhodopis), 69.

Dositheus (Priest and Levite), 5,6 .

Driver, II, $3 \mathrm{I}$.

Dura (=Durilu), I36, I37.

Durilu (temple of Anahita at), 137.

H.
Ecbatana (a Persian capital), I 26 , I 34,297 .

Ecclesiastes (liook of), I 15.

Edict of Artaxerxes (II ?), I o I.

Edom, 22 .

Edomites, 14, 86.

Egypt, 3, \&c.

Ehud (judge), 24.

ekal (hethali, so6.

Elam, 28 .

Elamites, 28, 29.

Elders of Israel (in Ezekiel), 88 , 96.

Elementary gods, 125.

Elephantine Papyri (Sachau), 95, I70.

Eliashib (High Priest), I 70.

Elijah (the High Priest), I9I.

Emblem of Ahuramazda, 98, 124.

Enchantment (definition of), 162.

Encyclopaedia Biblica, 20.

Britannica, 99, 120.

En-lil of Nippur, 12 I.

Enoch (Book of), I62.

Entstehung des Judenthums (Ed.

Meyer), $82,8_{4}$.

Epagomena (Festival of), 166-8.

EranischeAlterthumskunde (Spiegel I, I67.

Erech (City of), i 3 S.

Erez (Temple of Anahita at), 127.

Esau, 22.

Esoteric religion of Zoroaster, IOI.

Esther (Book of), its story being discredited by modern exegetes, 1-2; its Greek version, 2-7; its Rabbinic interpretation, 710; its facts misinterpreted, and its action placed in a wrong period, II-12 ; being interpolated in the Maccabean period, $12-14,175,240-4$; its compilation, I I2-I7, 28I; (Fast of), $28 \hat{3}-9$ : (the Oueen), her 
religious conceptions, 106-9, 147 -8 ; her messages to Mordecai, 192-200; inviting Haman to the banquet, 20I-4; her accusation of Haman, 219-24; informing the king of her relationship to Mordecai, 232-4; beseeching the king to reverse Haman's decree, 237-40; her request concerning the Jews of Susa, $25 \delta-61$; her confirmation of the matter of Purim, 289-90.

Esther and Judith (Willrich), 2, S.c.

Esther bei den LXX (Jacob), 2, S.C.

Esther (Das Buch, Cassel), II, S.c.

Esther (Das Buch, Jampel), 9, \&c.

Ethiopia, 31, 52.

Eunuchs, 79, 187-92, 202, 207.

Euphrates Valley, 90, 92, 121.

Europe, 123.

Exhortations to the Greeks (Clemens), 129.

Exodus (Book of), I 13 .

Exoteric religion of Zoroaster, Ior.

Ezekael (angel), 162.

Ezekiel, 20, 26, 82, 85, 86, 88, 91, $95,96,116$.

Ezra, 19, 24, 40, 80, 101, 102, 109, I10, I11, I12, I16, I70, I7I, 172 .

Farioardigan (= Purim?), 164 , 264,272 .

Fast Days, 283-9.

Fast of Esther, sce Esther.

Fathers of the World (Sirach), I 16.

Festival of Anahita, sce Anahita.

Festival of Magophonia, I4I.

Festival of Purim, see Purim.

Festivals of the Season, 272.
Flavius, Josephus, 6, 7, 25, 70, 79, 103, 133, 157, 177, 252.

Fragmenta Historicorum Graecorum (Müller), I I 9.

Frudsha (pr. n.), 70.

Fundamente Israelitischer und Jüdischer Geschichte (Marquart), II9.

Fürst, Julius, I65.

$G \bar{a} \bar{s} a, G \bar{a} g \bar{\imath}, 25,26$.

Galilee, 3 I.

Gallows (prepared for Mordecai), 204, 205.

Galuith-ha-Shekinah, 92.

Gathering of the virgins, 150.

Gaumata (name of PseudoSmerdis), 129, 298.

Geldner, K. F., 27, 2S, 41, 99, IOO, 101.

Genesis (stories of), 89.

Geography (Strabo), 127, 129.

Geōnìm, 107.

Gera (father of Shimei), I8.

Germanica (Tacitus), 216.

Germans, 2 I6.

Geschichte des Alterthums (Ed. Neyer), I2, \&c.; des Alttestamentlichen Schrifthums (Kautzsch), 9; der Poetischen National-Literatur der Hebräer (E. Meier), 165; des Volkes Israel (Hitzig), 164, 165; des Volks Israel (Stade), 170.

Gideon (judge), 24.

Gōg (in Ezekiel), 26, 27.

Golden image (of Anahita), I27, I 36,137 .

Göttinger Gelehrte Anzeigen, 102, 167.

Göttinger Gelehrte Nachrichten, I70.

Graeco-Roman period, I09. 
Graetz, Heinrich, 24, S8, 93, 94, $95,97,101,133,134,236$.

Grecian States, 123.

Greece, 33, 34, 36, 43, 52, 54, 121.

Greeks, 35, 37, 51, 54, 73, 74, 76, $86,102,123,143,148,241,251$.

Greek Version of Esther, 2-7, 22, $66,70,79,80,109,175,185,242$, $244,262,268,269,272,275,285$.

Grote, G., 38 .

Gyndes (river), 37 .

Hades, roo.

Hadoram (= Joram of Hamath), \&2.

Hagadah shel Pesah, 276.

Haggai (prophet), I 6 .

Haman, represented as descendant of Agag, 2I-9; author of the reform of the Zoroastrian religion, $139-47$; as persecutor of the Jews refused homage by Mordecai, 153-9; his casting of the Lots, 159-69; his accusation of the Jews, I69-70; his decree, 17t-7; invited to Esther's banquet, 200-5 ; prepared gallows for Mordecai, 204-6; proposing honours for himself and bestowing them upon Mordecai, 209-15; his downfall and execution, 21527; parallel between his fate and that of Tissaphernes, 2279 ; his property confiscated and his family apprehended, $230-2$; execution of his sons and their bodies exposed, 258-6I.

Hammer, J. von, I65. Hammurabi (reign of), 121. Hammurabi Lynasty, 121 . Hananiah (= Shadrach), I8\$. Hanukkah (Festival of), 166. Haoma (angel), 27, 28, 129.
Harbonah (Jewish eunuch), 192, $225,226,227,270$.

Harem, 20, 47, 71, I5I.

Harper, William Raney, 2.

Harpates (murderer of the third son of Artaxerxes 11), 49 .

Hart, J. H. A., 297.

Hastings Encyclopaedia, 26, 99.

Hathach (Jewish emuch), I86, I 92, 194, 195, 196.

Haupt, Paul, 2, 14, I \&, 20, 21, 23, $25,67,163,164,177,205,207$, $212,220,222,224,239,240,243$, $256, .265,267,27 \mathrm{I}$.

Hebräische Uebersetzungen des Mittelalters (Steinschneider), 160.

Hebrew and Babylonian Traditions (Jastrow), 90.

Hebrew language (criterion of Judean nationality), 82, 83 .

Hebrew Lexicon (Brown-Driver), $23 \mathrm{I}$.

Hecataeus of Abdera (Greek author), 133, 135, I69, 244.

Hellenists, 107.

Hellespont (scourged by Jerxes), 37.

Hephaestion (general under Alexander), 234.

Hera (= Anahita), 125.

Heraclides of Cyme (Greek author), 43, 49.

Hermes (pr. n.), 105.

Hermocrates (sent into Greece by Artaxerxes 1I), 52.

Herod (king of Judea), 22.

Heterodoxy (in Judaism), 107, I I I.

Herodotus, 9, 15, 26, 28, 31, 34, $37,3^{8}, 39,62,69,99,100,125$, $148,151,154,155,158,173$, $174,177,178,181,187,191$, 194, 200, 203, 216, 217, 218, 226, $231,298$. 
Het Herstel van Israel (Kosters), I02.

Hezekiah (king of Judah), 24, S2.

Hillel (School of), I I 5.

Historisch-kritische Einleitung (Kuenen), Io2.

History of the Jewish Church (Stanley', 9, I06; of the Jews (Graetz), 24. \&c.; of the people of Israel (Renan), 88, \&c.

Hittites, 26.

Hitzig, F., 66, I64, I65.

Holy Fire (of Ahuramazda), I25, 138 .

Holy Spirit (Jewish), II5, II6; (Zoroastrian), Ion, I 29.

Holy Wars (Persian), I4 I, I44.

Hôm-date (= Hamdatha), 129.

Hommel, Fritz, 165.

Humma (= U mma), 28 .

Hutaosa (= Hadassah), 106.

Hydarnes (father of Stateira), 58, $60,232$.

Hypocoristica, 104.

Hyrcania (banishment of the Jews to), 236 .

Hyrcanus (1), I 4 ; (II), 7.

Ibn Ezra (Abraham), 17, 31, 41, 10\&, $285,286,287,288,291$, 292.

Ilu-ur-ri (pr. n.), Io6.

Independence Day (America), 264.

India, 31, 52 .

Indians, 297.

Indra (Aryan deity), 28 .

Intaphernes (conspirator against Pseudo-Smerdis), $23 \mathrm{I}$.

Intermarriage, I09, I10, I7I.

International Critical Commentary, 2, \&c.

Interpolators, $1_{3}-14,175,240-2$.

Iran. 128 .
Iranian, $98,120,127,128,141$, I 42, I 43, I 46 .

Iranisches Namenbuch (Justi), 29, \&ic.

Isaiah (Second), $\delta_{4}, \delta_{5}, 87,97,98$, IOI, I 25, I $89,253$.

Ishtar (identified with Anahita), 125, 126, 138; (= Esther), I 06.

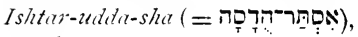
I06.

Isidorus (pr. n.), I05.

Islam, 122, I6I, 228 .

Israelitische und Jüdische Geschichte (Wellhausen), 27, 102.

Izates (embraced Judaism), 157.

Jackson, A. V. Williams (Zoroaster), 27, 122, $14 \mathrm{I}, 296$.

Jacob, B., 2, 4, 5, 6, 25, 32 .

Jahn, G., 2, 4, 6, 8, 285 .

Jahrbücher für Literatur (Hammer), 165.

Jair (father of Mordecai), 16, I8, I05, 106.

Jampel, Siegmund, 9, I I, I 8,34 . $36,37,3^{8}, 116,252$.

Jastrow Morris, jun., 90.

Jazi-ki"di (king of Hamath), $8 z$.

Jaudi (in Northern Syria), $\delta \mathbf{z}$.

Jawa (= Jahreh), I05.

Jeconiah (exiled king of Judah), I6, I 8, 19, Io3.

Jehoiachin $=$ Jeconiah, 93 .

Jehüdim, see Jews.

Jensen, Peter, 163, 165.

Jephthah (judge), 262.

Jeremiah (prophet), $87,88,91,93$,

97, I6I, 252, 288 .

Jeremias, Alfred, 26, I OI, I4I.

Jerusalem, 5, 16, 40, 102, I 16, I69. $172,250$.

Jethro, 247.

Jewish-Christian Era, Io7. 
Encyclopaedia, 20, 161.

idolators. $\$ 5,86$.

nationality (reform of), $\delta_{3-5}$.

patriots, $s_{4}$.

Ouarterly Review, New

Series, 90.

race, $108,119,156,157,110$,

I 69-72.

Jews, of Egypt not involved in

Haman's decree, 3-6; holding the liook of Esther in high honour, $9-10$; in the Alexandrian age, 13-14, 241-2; outside of the Persian empire, $34^{-5}$; persecuted on account of their religion, $36,11 S$; their attitude toward the Persian religion, 39-40, 10I-3; under the Arsacides, 76-9; definition of the term 'Jews' in pre-exilic times, $\mathbf{S} \mathbf{I}-3$; its reigious significance in post-exilic times, $8_{3}-93$, as Egyptian immigrants, $93^{-5}$; their leaders, $95^{-8}, 103^{-}$ 6 ; their religious propaganda in Babylonia, 96-7; under the Achaemenides, 97-8; refusing to worship Anahita, 130; the attitude of the people at large toward her worship, I3I ; engaged in commerce, $13 \mathbf{1}-2$; in Palestine, 133-6; being persecuted, I $43^{-7}$; their wealth, I77-8; their religious observances, 249-51 ; giving permission of defending themselves, 244-61; acceptins the Festival of Purim by common consent, $27+-89$.

Jezebel, 288 .

Job, I 16.

Johanan (High Priest), I7o.

(Syrian author), 74.

Jonathan (High Priest), I 70.
Joram (son of the king of Hamath). 82. Joseph, 234. Joshua (High Priest), I9, 20. Josiah (king of Judah), $88,94$.

Kanon des Alten Testaments (Fiirst), 165.

Karaites, $107,282$.

Kassites (Dynasty of), 28 .

Kautzsch, Emil, 9, 10.

$k e$, ka (Persian hypocoristic termination ), $78,79,188$.

Keil, C. F., 9, 31, 32, 40, 193.

Keilinschriften und das Alte Testament, r6o.

Khi-sha-ar-shu (= Xerxes), 78 .

$K h$ shay $(\bar{u} r s h u(=$ Nerxes $), 78$.

Kiepert, H. (Map), 26.

Kish (fellow-captive of Jeconiah), I6.

(father of King Saul), 17, I8. (name of Levites), 19.

Kokab-el (angel), 161, 162.

Kosters, 102.

Krausz, J., I0 4 .

Kuenen, Abraham, 102.

Lacedaemonians, 54, 55, 63, I 4 I, i79, $215,226$.

Lagarde, Paul de, 2, 13, I29, I63, $166,167,283$.

Leben nach dem Tode (Schwally), 165.

Letter of Purim, 266, 270, 277, $278,280,283,295$.

Leuctra (battle of), 232 .

Levi (tribe of), I9.

Leviticus (book of), 189.

Lewy (Handbuch), 22.

Literarisches Centralblatt, 165.

Local gods, 9 I.

Lucian, Lucianic Recension, 23, 25, 26, 70, 79 . 
Lunar year, 168.

Luther, Martin, S, 9.

Lydia, Lydian, 54, I77, 178.

Lysimachus (of Jerusalem), 5 .

Maccabean period, IS, 86 .

Maccabees, 3, 14, 241, 242, 254.

Macedonian ( $=\operatorname{Ag}$ g $\bar{l} \bar{l}), 269$.

Magi, Magian, 27, 55, 100, 130, 141, 168, 169, 214.

Maimonides, 160 .

Malachi, i 16.

Marathon (battle of), $5 \mathrm{I}$.

Marduk (Bel-), I8, 38, 56, 92, 104, I05, I21, 248.

Marduka, Marduku (pr. n.), 104.

Marduk-bil-shunu (= Mordecai bilshan), I04.

Mardus (= Smerdis), 298.

Marquart, J., 26, 40, I0I, I25, 126, 143, 148, I69, 190.

Marseilles (men of), I60.

Masistes (brother of Xerxes I), $23 \mathrm{I}$.

Materials to a Sumerian Lexicon (Prince), 163.

Mazdeism (= Zoroastrian religion), 99.

Megabyzus (one of the conspirators against Smerdis), I87.

Megasthenes (Greek author), 297.

Megiddo (battle at), 93, 94, 95.

Megillah (= the Scroll), 167.

Megillath Tatanith, 284 .

Meier, Ernst, I65.

Meissner, Bruno, 165.

Menon (Greek commander in Cyrus' army), 61 .

Mercury (= Persian Tèr), 70.

Mesabates (eunuch), I9I.

Meshach (= Mishael), 188.

Mesheih (= Mushlii), 26.

Metiochus (son of Miliades), $2 S$, $\mathbf{1}+8$.
Meyer, Eduard, I 2, 27, 32, 34, 38, $39,43,48,50,51,56,75,76,77$, $84,87,88,98,99,120,121,123$, $124,126,168,169,187,188$, 190, 236, 293.

Michaelis, J. D., 214.

Middle Ages, \$6, I07, I3I.

Midianites, 24.

Midrash, 7, S, 22.

Miltiades, 28 .

Minerva, 39.

Mirchvand (pr. n.), 7o.

Mishael (= Meshach), I88.

Mishnah, I08.

Megillah, I67.

Parah, I64.

Mitanni, 28.

Mithra, 125.

Mithradata (pr. n.), 27.

Mithra Feast, 126.

Mithridates (the slayer of Cyrus), 62.

Mitra (= Mithra), 28 .

Mohammedans, 90, I19, I6I.

Moloch, S2.

Monotheism, 162, 163, 248, 249, 272.

Monotheist, Monotheistic, I24, 135, 147, 162.

Mordecai, his genealogy, 16-19; his information of Esther, 20I ; racial contrast between him and Haman, 2I-9; his religious conceptions, 103-12 ; concealed his connexion with the Jews, 147-9; his position at the court, 149-50; revealed the plot against the life of the king, 149-52; refused to bow down to Haman, 153-9; his conduct on learning of the decree against the Jews, $184-6$; sources of information at his disposal, 18694; the messages exchanged 
between him and Esther, 1949; honoured by Haman, 207$1_{4}$; installed as Haman's successor, 230-5; his decree, $237^{-}$ 45 ; his public appearance as grand vizier, $245-6$; established the Festival of Purim, 263-5; his Letter of Purim, 265-72; his success as grand vizier, 293-5; his Persian name, 2978 ; his eulogy, 298-9.

Moschians, 26.

Moses, 104, I09.

Moslems, 242.

Müller (Frag. Hist. Graec.), I I 9. Mycale (battle of), 32, 49 . Mylitta (= Anahita), 134 .

Mythology, 89.

Nabü (= Tēr), 70 .

Nabü-bì-shunu (pr. n.), 104.

Nabü-na'id (king of Babylonia), 97.

Nabü-nasir (pr. n.), Io4.

Nabü-shakin-ud-du (pr. n.), I06.

Nanā-iddin, 105.

Nana $\vec{t}$-Ishtar, 138 .

Nasatya (Aryan deity), 28 .

National consciousness, $82-3$.

Nazarenes, 86 .

Nebuchadnezzar (king of Babylonia). 16, 88, 91, I88; (= Artaxerxes I1). 136-8.

Nehemiah, 83 , I09, I I I, I I 2, I I6, $148,169,170,171,172,190$, 250.

Neo-Persian empire, Neo-Persians, 52, $141,168$.

Neubabylonisches Namenbuch (Tallquist), 104.

Nergal (deity). 248.

New Year Festival (Jewish), I60 ; (Babyl. and Pers.), 59, I59, I64.
Nicanor I)ay, 3, 284 .

Nin-io (deity), I62.

Nin-ib-bé-sunu (pr. n.), $\mathrm{IO}_{4}$.

Nin-ib-maballit (pr. n.). 105.

Nisan (month), 56, I68.

Noah, 16.

Nöldeke, Theodor, 20, 102.

Nowack's Hand-Commentar zum

Alten Testament, 2.

Nüri-Ishtur (pr.n.), 106.

Oarses (= Arses), 77, 78 .

Ochus (Artaxerxes IlI), 47, 48, 52.

October-April (coronation festivities), 56-7.

Og (king of Bashan), 262.

Old Testament in the Light of the Ancient East (Jeremias), Ior.

Olympics, 122.

Omanos (= Vohuman), 129.

Oral Law, 114.

Origen (letter of), 7 .

Origin of Purim, Ifo.

Oropastes (= Smerdis), 298.

Orthodoxy, 107, 111.

Ostanes (brother of Artaxerxes I1), $44,6 \mathrm{I}$.

Otanes (father of Phaedima), 151 , 187, 194; (father of Amestris wife of Nerxes I), 34 .

Öttli, 220, 222.

Oxatres (brother of Artaxerxes II), 44, 61 .

Pahlavi (middle dialect of the Persian language), $15_{3}$.

Pairish-teira (pr. n.), 70.

Palestine, 3, 79, 169, 244, 250, 265,284 .

Pallas Athene (= Anahita). 125.

Paris (Bretons at), 90.

Pariscas (chief eunuch of Cyrus), I9I. 
Parthia, Parthian empire, Parthians, 75, 76, 79, I41, I8o.

Parysatis (mother of Artaxerxes II and Cyrus), 44, 46, 47, 54, 55, $58,59,60,61,65,70,73,158$, $201,232$.

Pasargadae (consecration at), 54, $73,227$.

Pashshümu (= türu), I63.

Passover (Festival of), I68.

Paton, L. 13., 2, 4, 6-II, I4, I8, $2 \mathrm{I}, 3 \mathrm{O}-2,40,57,62,63,73,108$, I $52,153,156,167,177$, I 81 , $185,191,194,196,199,200$, 206, 207, 210, 213, 215, 220, 223, 224, 235, 259, 291, 296.

Patriarchs, $89,273$.

Persae (of Aeschylus), 7o, 298.

Persephone (= Anahita), 125.

Persica (Ctesias), 43 , \&c.

Persian annals, 207, 296, 297; calendar, I68; customs, 64, 65 ; proper names, I 28 , I42; wars, I2O.

Pharisees, 3.

Phaedima (wife of Cambyses, Pseudo-Smerdis and Darius), I 5 I, 194.

Pharaoh, 234.

Pharnabazus (Persian satrap), 53.

Philhellene (epithet of Arsaces Mithridates), 76 .

Philistines, 24.

Philosophers, 107, 297.

Phoenicia, 236.

Phoenicians, 34, 249.

Phrourai (Letter of), 5 .

Phiur (= New Year), I64.

Planets, 90, I60, 162.

Plataea (battle of), 32, $5 \mathrm{I}$.

Plutarch (Life of Artaxerxes), 42, $49,57-62,65,70,73,123$, I 50, I 5 I, 20I, 209, 2IO, 2I 5, 223, $227,228,23 \mathrm{I}, 235$.
Polytheism, I61, I63, 248, 272.

Polytheistic, 122, 124, 126, I 43, $146,256$.

Pontus (temple of Anahita), I27.

Poseidon (chastisement of), 37 .

Post-dating, 56.

Prayer of Esther, I 09. Ezra, I 70.

Pre-Mlosaic period, 90.

Prexaspes (Persian grandee), 216, $23 \mathrm{I}$.

Prince, J. D., 20, I63.

Prinz und Derwisch (Weisslowitz), I65.

Promulgation of the Law, 170-2, 290.

Prophetic Universalism, 251.

Proselytes, $\delta_{4}, 86,246-54$.

Prostitution (cult of Anahita), I 26.

Protestant theologians, 7 .

Psalms, 246, 299.

Pseudo-Smerdis, 34, I4I, I68, 23 I, 232.

Ptolemy (king of Egypt), 5 . (son of Dositheus), 5 .

$\operatorname{Pür}(=a b m u)$, I63.

Purim (Festival of), not observed in Egypt, 3 ; its observance in the pre-Maccabean period, I2 ; simultaneous with the festival of Anahita, I66-S; the etymology of its name, 272 ; the special significance of its observance, 274-7: its establishment against the consent of the Sopherim, $278-\delta_{3} ;$ confirmed by a royal decree, $289-9 \mathrm{I}$.

Purim (Haupt), 14, Sic.

l'urim (Lagarde), I66, \&.c.

Pythus (Lydian), I77, I78.

Rabbi Asher, 283 . Jacob Tam, $28 \hat{\text {. }}$. 
Jose (Tanaite), I 15. Joshua son of Hananiah, II 3 , II 5 .

Meir, II 5 .

Simeon, 115.

Ranke, H., 78.

Rashi, 22, 32, 86 .

Rawlinson, G., 39, 45, 62, 69, 100, 151, 168, 178, 187, 188.

Rawlinson, Sir H, I88.

Reform of the Zoroastrian religion, I 25-8, I $30,146,165$.

Religion and State, I20-I.

Religious Aspects and Beliefs in

Babylonia and Assyria (Jastrow), 120.

Community (Jewish), $\delta_{4}, 97$.

Creeds (influence of), 88,89 . Persecutions, IIII II8, II9, I 3 I, I 32, I 33, 139.

Propaganda, $87,96$.

Renan, E., 69, 88, 90, 92, 95, 96, 105, 129.

Reuben (tribe of), I 8 .

Rhōdōpis (epithet of Doricha), 69.

Richardson, 69.

Riehm, Ed. K. A., 9.

Roman Epoch, I05.

Governors, 178 .

Laws, 63.

Romans (under the), 172.

Rome, 22, 260 .

Rosh Hashanah (Tractate of), 284 .

Russian Jews, It. Pogroms, 252.

Sabbath, 85, 249, 250.

Sachau, 95 .

Sacred Books (Zoroastrian), I 4 , 296.

Vessels, 164 .

Sadducees, 107.

Salamis battle of), $32,5 \mathrm{I}$.
Samaria (inhabitants of), $\delta \mathbf{2}$.

Samaritan, I IO, 135.

Samson (= Apollonius), I05.

Samuel (Principal of Nahardea Academy', 115.

(Prophet), 24, II4.

Sanballat (Samaritan), i Io.

Sandoces (Persian governor), 158.

Sanhedrin, III.

Sappho (Greek poetess), 69.

Sardis (capital of Lydia), 33, 120.

Sariel (angel), I62.

Sassanides, 50, 98, 163, 228.

Satibarzanes (eunuch), I9I.

Saul (king of Israel), 16, 17, 18, 21, 24, 91.

Scepticism, 13, 247.

Schrader, Eberhard, 26.

Schwally, $165,167$.

Scythians, 35, 36, 37 .

Seleucia, 251 .

Seleucides, 13 .

Semites, $84,188,249$.

Shabti-el (angel), I6I.

Shadrach (= Hananiah), I 88 .

Sha-la-bill(ti?)-shum (pr. n.), IO4.

Shamai (School of), II 5.

Shamash (Sun-god), 106, 125, I61, 248.

Shamshi-el (angel), 161, 162.

Shimei (grandfather of Mordecai), I6, Is.

Siegfried, Carl, 2, 8, 17, 18, 20, $21,40,57,66,108,150,156$, 194, 198, 200, 213, 222, 224, $245,285$.

Sihon, 262 .

Simeon (tribe of), 105.

Sirach, 6, I 16.

Smerdis, 298 .

Sogdiana, 180 .

Sogdians, 166.

Sogdianus (successor of Nerxes II),

54. 
Solar Year, I68.

Solomon (king of Israel), 125.

Soma (Vedic $=$ Haoma), 28 .

Sopherim, I I2, I I 3, I I4 $, 263,265$, 280,281 .

(Tractate of), 283, 284,

Spanish Jewish preachers), 89, 90 .

Sparta, 52, 53.

Spen-dat, Spenda-dat (father of

Vohuman), 129.

Sphenda-dates (= Pseudo-Smerdis), I 29, 298.

Spiegel, I67.

Spring Festival, I 59.

Sta (element in Persian names), 70.

Stade, B., 2, 170.

Stanley, A. P., 9, I06, I I6.

Stateira (wife of Artaxerxes II), 58-62, 68, 69, I58, 203, 232.

Steinschneider, M., I6o.

Strabo, 127, 129.

Strassmeier, 77.

Stromata (Clemens), I 28 .

Sumero-Babylonian, 106, 164.

Syria, 3, 79, 94.

Syrians, I 4, 34, 24 I, 25 I, 254.

Ta'anith (Tractate of), 285.

Tallquist, K., I 04, 298.

Talmud Babli Megillah, 7, 8, 67, 85, 90, I03, I04, I I I, II 2, I1 3 , 114 , I I 5, I 16, I38, I 54, I67.

Menahoth, 7, I04.

Sanhedrin, I62.

Shabbath, I45, I62, I7I.

Yoma, 20.

Tanyoxarces (= Smerdis), 298.

Targumim, 7, 8, \&c.

Targum, Second, I9.

Tauranitis (worship of Anahita), 127.

Temple of Job, 95 . of Jerusalem, 169 .
$T \bar{e} r$ (element in Persian names), 70.

Teribazus, Tiribazus (Persian grandee), 46, 47, 49, 209, 2 I 0.

Teridates, Tiridates (brother of Parthian Arsaces), 70, 75, 76, 81. Teriteuchmes(brother of Stateira), $58,70,158,232$,

Teumman (Elamitic pr. n.), 28. Thanksgiving Day (American), . 264 .

Theocratic constitution, I 21 .

Thrace, 4I, 5 I, 74 .

Tibarenians (= people of Tabal), 26.

Tishri (month of), 172.

Tissaphernes (Persian satrap), 54, 53, 78, 1 58, 201, 226.

Titus (Flavius), 284 .

Tobit (Book of), 30 .

Togarmah (= Til-garimu), 26.

Tubal (= Tabal), 26.

Turanians, 127.

Turkish empire, Turks, 123.

Twelve Tables (Roman Law), 63 .

$U d-d a$ (element in Babyl. pr. n.), Io6.

$U d-d u(=u d-d a)$, 106.

Udiastres (murderer of Teriteuchmes), 158.

Um-man (Elamitic deity), 28.

Ummanaldasi (Elam. pr. n.), 28.

Ummanigash (Elam. pr. n.), 28 .

Urartu (= Armenia), 26.

urru (synonym of $u t$-da), 106.

Urud-Malik (pr. n.), Io6.

Vahuk (= Ochus), 7o.

Vardan (= Rodanés), 70 .

l'aruna (Aryan deity), 28.

Iashtak (Pers. pr. n.), 70.

Vashta-teira $(=$ Asta-teira $=\$$ Sta teira), 70 . 
Vashti (wife of Ahasuerus), 58, 60, 62-72, 199.

Vaumisa (Pers. pr. n.), 7o.

Vedic, 28 .

Vendìdād Fargard, 164.

Vernal equinox, I 59 .

Viakhna (= Adar), I68.

Vidarna (= Hydarnes), 70.

Vindafarna (= Intaphernes), 70.

Iohuman (son of Spen-dat), 128, I 29.

IV asti ( $=$ Vashti), 70.

Wellhausen, J., 27, 102, 170.

Westland, 9o.

Wildeboer, 9, 17, 1 \&, 20, 21, 31, $40,57,66,150,165,194,200$, $212,213,217,220,233,234$, 256,285 .

Willrich, H., 2, 3, 4, 5, 7, 9, 32, I 33 .

Winckler, H., 25, 26, 28, 32, 165.

Winged Ring, 99, 124.

Xenophon, 57, 179, 298.

Xerxes I, 12, 15, 16, 30, 31, 32, 35,
$3^{8}, 41,42,51,73-5,100,177$, 23I, 291, 292, 296.

II, 54,78 .

Yashtishat (temple of Anahita), 127.

Zadok (High Priest), I9.

Zarathustra $=$ Zoroaster.

Zechariah (prophet), II6, 282.

Zeitschrift für Alttestamentliche

Wissenschaft, 2, \&.c.

für Assyriologie, 77 .

der Deutschen Morgenländischen Gesellschaft, 165 .

Zend-Avesta, 99, \&c.

Zimmern, H., 160, 163, 165.

Zodiak (signs of), 90, I6o.

Zoroaster, 98, 1 20, 1 25, 128, I 43, 168.

Zoroaster (Jackson), 27, 122, 128, $14 \mathrm{I}$.

Zoroastrian, Zoroastrianism, 26, $38,39,55,98-100,102,103,120$, $122,124-30,137,140-4,235$. $238,250$.

Zunz, L., 165.

\section{II}

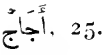

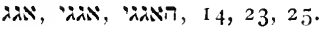

אגרת הפורים , 295.

אזישררפנים (= Satraps), 3 ז.

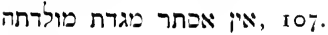

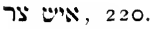

אלנתה (= Bagadatha), 27.

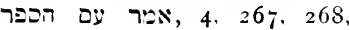
$27 \mathrm{I}$.

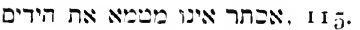

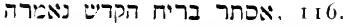

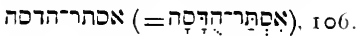
ו 6.

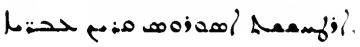

74 .

293. 29.

. $10 \%$, ארי; וביולדת ואים

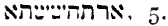

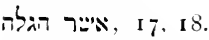

68. 


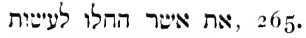

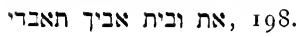

24, 27.

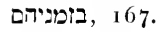

232.

זנפר רורה רוים 232.

253. 253.

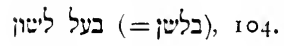

256.

גה. 25.

; ג' ימים שהתענו בנים 286. גiג, 25.

גורל 163 .

286.

גם הגה העין 226.

285 , דברי האמת כעצתם 285

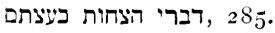

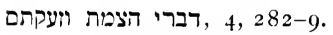

דברי הצמות על הניברים ביבריה, רניהם יותים, 287 .

290.

282.

286. I08.

ו, רת מישה וישראל יהורית.

282.

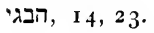

226.

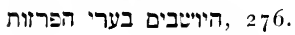

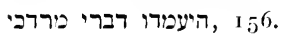

I8z , המלך והמן יישבו לישתות , 8 .

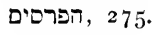

288.

הצום יצמתוגי אילה 220.

257.

239.

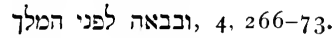

268.

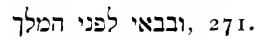

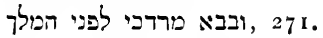

. 243.

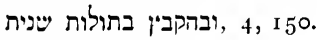

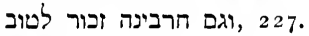

286.

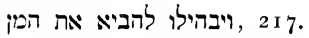

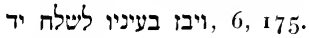

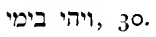

244.

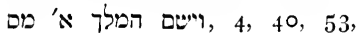

292-3.

I98. וכאשר אברתי אבדתי

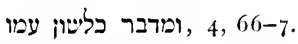

ונהגו להתענות ביום שלפני פורים עמוים, 284.

262.

291.

2ופני המן חפוב בספר $224,26$.

4, 4, 23 I.

- 247, ורבים מעמי הארין מתיהדים ורניו

54.

243 , וישללם לבוז

ו ועקה גרולה ומרה 185. 
. 57 , חיל פרס ומדי

זעם 2 I .

6יה , 266, 267, 272.

240, 243.

היהודים ,יהודים ,יהודי , 81, 82, 85, 86 , 102, I 1 $8,131,13^{2}, 156$, I $57,159,212,213$.

226.

28 28. 28 ייום התענית ורית

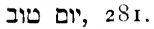

, 277.

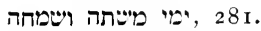

.

32 . כישנתקישה המלכות בידו

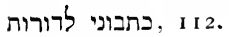

כתוב יאה זכרון בספר לרורות , II2, II4.

לאבד את (עם) היהורים 175.

לאברם 266, 267, 269. . 284. . 22.

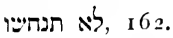
להים 196.

$219,220$.

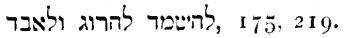

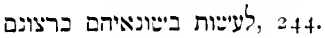
260. 24t.
256. מדינה (= Judge's circuit), 3 I.

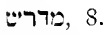
מיה הויא לה 2.32.

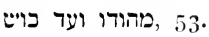

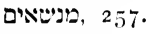

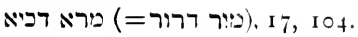

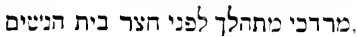

20.

מתיחרים, $25 \mathrm{I}$.

Pij, 220, 221.

נתנאל (=Bagadatha), 27.

268.

7פ0, 290, 29I.

ספר הזכרונות $207,291$.

257. 257 . עוורים

239.

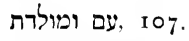

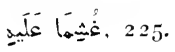

פח $236,247$.

תחות, 3 I.

283.

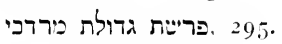

295.

טיכ. 8.

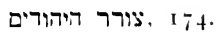

7ร. 220.

קבעוקי לרורות II4.

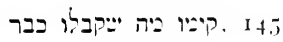


. 232.

(רש״"ב"א), רבי ישלמה בן אררת, 90.

."שרה 232.
4 , ישב ואל תעישה עריף 4 , ישם ירים

20.

284 ,'ישי ותמישי ושים ירקי

. $280,285$.

\section{III}

'A $\gamma$ ayaios, 23.

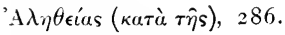

A $\sigma \pi \alpha \mu i \tau \rho \eta \bar{s}, 70$.

'A бти́ктоs (= Vashtak), 70.

'A $\sigma \tau \alpha \dot{\sigma} \sigma \pi \eta \varsigma, 70$.

"A $\sigma \tau \eta \bar{s}, 70$.

"A $\sigma \tau \iota$ (= Vashti), 70.

'A

"A $\sigma \tau i v$ (= Vashti), 70.

'A rírpos (= Ahasuerus), 79.

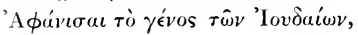

I 75 .

Bayaîs, 23 .

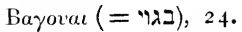

Bov $\gamma \alpha \theta \alpha \nu$ (= B $\alpha \gamma \alpha \theta \alpha \nu), 2.3$.

Bovyaios, $23,26$.

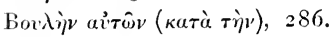

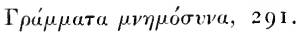

$\Gamma$ wraios, $23,25,26$.

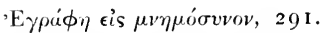

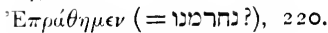

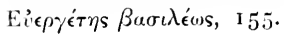

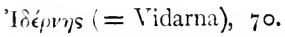

'I

Mápdos, 298.

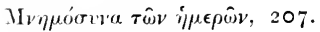

Хi,

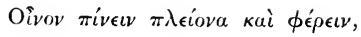

55 .

${ }^{\prime} \mathrm{O}_{\rho} \delta \dot{\alpha} \nu \eta \mathrm{s}\left(={ }^{\prime} \mathrm{P} o \delta \alpha^{\prime} \nu \eta \mathrm{s}=\mathrm{Vardan}\right)$, 70.

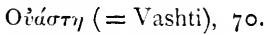

Oíúorıv (=Vashti), 70 .

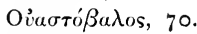

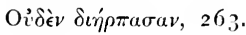

II $\rho \circ \sigma \kappa v ́ v \eta \sigma \iota s, \mathbf{I}_{53}$.

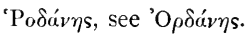

$\Sigma_{\pi \alpha \mu i \tau \rho \eta s}(=' \mathrm{~A} \sigma \pi \alpha \mu i \operatorname{\tau } \rho \eta \mathrm{s}), 70$.

$\Sigma_{\pi \alpha \sigma i v \eta s}\left(={ }^{\prime} Y_{\sigma \pi \alpha \sigma i v}\right\rangle$ ), 7 ○.

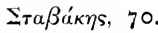

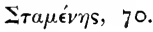

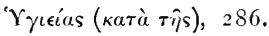

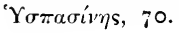

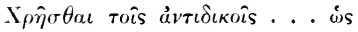

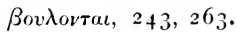

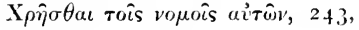
244 .

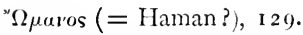

" $\Omega \mu \iota \sigma o s$ (= Vaumisa), 70.

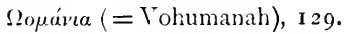

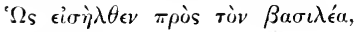
269.

s $\chi$ os (= Vahuk), то. 






\section{0}

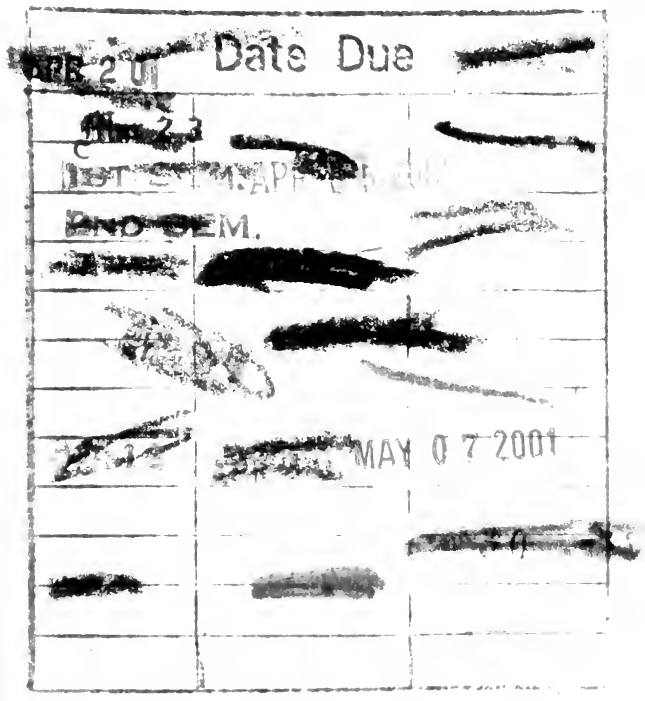




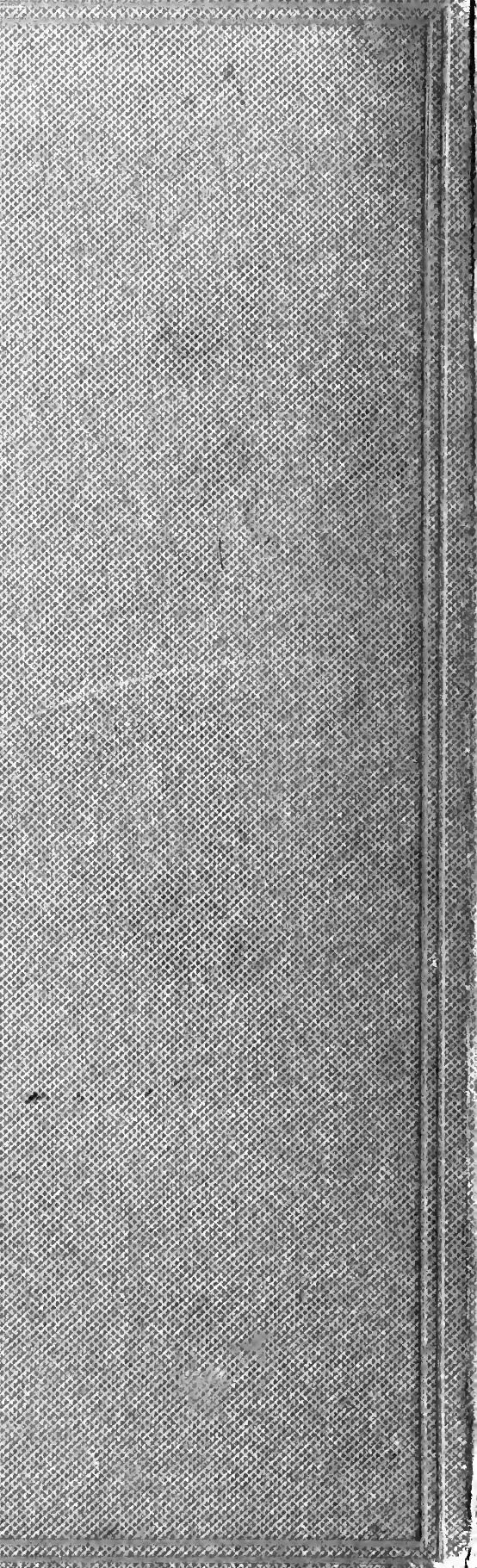

